



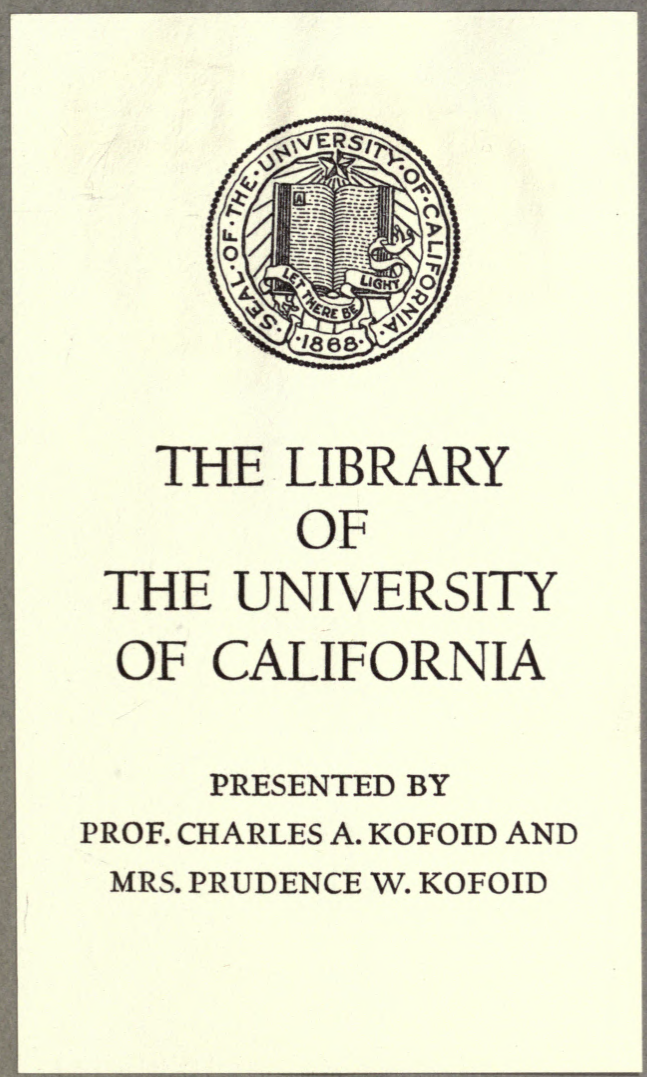





\section{BULLETINS}

OF THE

\section{State Geological and Natural History Survey of Connecticut.}

I. First Biennial Report of the Commissioners of the State Geological and Natural History Survey, 1903-I904.

2. A Preliminary Report on the Protozoa of the Fresh Waters of Connecticut : by Herbert William Conn.

3. A preliminary Report on the Hymeniales of Connecticut: by Edward Albert White.

4. The Clays and Clay Industries of Connecticut: by Gerald Francis Loughlin.

5. The Ustilagineæ, or Smuts, of Connecticut: by George Perkins Clinton.

6. Manual of the Geology of Connecticut : by William North Rice and Herbert Ernest Gregory.

7. Preliminary Geological Map of Connecticut: by Herbert Ernest Gregory and Henry Hollister Robinson.

8. Bibliography of Connecticut Geology : by Herbert Ernest Gregory.

9. Second Biennial Report of the Commissioners of the State Geological and Natural History Survey, 1905-1906.

I0. A preliminary Report on the Algæ of the Fresh Waters of Connecticut: by Herbert William Conn and Lucia Washburn (Hazen) Webster.

II. The Bryophytes of Connecticut: by Alexander William Evans and George Elwood Nichols.

12. Third Biennial Report of the Commissioners of the State Geological and Natural History Survey, 1907-I908.

13. The Lithology of Connecticut: by Joseph Barrell and Gerald Francis Loughlin.

14. Catalogue of the Flowering Plants and Ferns of Connecticut growing without cultivation : by a Committee of the Connecticut Botanical Society.

15. Second Report on the Hymeniales of Connecticut: by Edward Albert White.

I6. Guide to the Insects of Connecticut: prepared under the direction of Wilton Everett Britton. Part I. General Introduc- 
tion: by Wilton Everett Britton. Part II. The Euplexoptera and Orthoptera of Connecticut: by Benjamin Hovey Walden.

17. Fourth Biennial Report of the Commissioners of the State Geological and Natural History Survey, I909-I9IO.

I8. Triassic Fishes of Connecticut: by Charles Rochester Eastman.

19. Echinoderms of Connecticut: by Wesley Roscoe Coe.

20. The Birds of Connecticut: by John Hall Sage and Louis Bennett Bishop, assisted by Walter Parks Bliss.

21. Fifth Biennial Report of the Commissioners of the State Geological and Natural History Survey, I9II-I9I2.

Bulletins I, 9, I2, I7, and 2I are merely administrative reports, containing no scientific matter. The other bulletins may be classified as follows:

-Geology: Bulletins 4, 6, 7, 8, 13, 18.

Botany: Bulletins 3, 5, 10, I I, I4, I5.

Zoölogy: Bulletins 2, 16, 19, 20.

These bulletins are sold and otherwise distributed by the State Librarian. Postage, when bulletins are sent by mail, is as follows: No. I, \$0.01; No. 2, .07; No. 3, .08; No. 4, .06; No. 5 , .03 ; No. 6, .12; No. 7, .06; No. 8, .05; No. 9, .02; No. 10, .08; No. II, .07; No. 12, .02; No I3, .08; No. I4, .16; No. 15, .06; No. 16, .07 ; No. 17, .02; No. 18, .07; No. 19, .08; No. 20, .14; No. 21 , .02 . The prices when the bulletins are sold are as follows (including postage) : No. I, \$0.05; No. $2, .35$; No. 3 , .40; No. 4, .30; No. 5 , .I 5 ; No. 6 , .50; No. 7 , .60*; No. 8 , .20; No. 9, .05; No. 10, .35 ; No. II, .30; No. 12, .05; No. 13, .40; No. 14, .75; No. 15 , .35; No. $16, .35$; No. 17 , .05; No. 18 , .25; No. $19, .45$; No. $20, .48$; No. 21, .05.

Bulletins $\mathrm{I}-5$ are bound as Volume $\mathrm{I}$. The price of this volume is \$I.50. Bulletins 6-12 are bound as Volume II. The price of this volume is $\$ 2.45$. Bulletins $13-15$ are bound as Volume III. The price of this volume is $\$ 2.50$. Other volumes will follow.

It is intended to follow a liberal policy in gratuituously distributing these publications to public libraries, colleges, and scientific institutions, and to scientific men, teachers, and others who require particular bulletins for their work, especially to those who are citizens of Connecticut.

Applications or inquiries should be addressed to

GEORGE S. GoDARD,

State Librarian, Hartford, Conn.

- If map is mounted as a wall map, and sent by express, $\$ 1.60$. 


\section{CATALOGUE SLIPS.}

Connecticut. State geological and natural history survey. Bulletin no. 20. The birds of Connecticut. By J. H. Sage and L. B. Bishop, assisted by W. P. Bliss. Hartford, 1913.

$370 \mathrm{pp} ., 23^{\mathrm{cm}}$.

Sage, John Hall.

The birds of Connecticut. By John Hall Sage and Louis Bennett Bishop, assisted by Walter Parks Bliss. Hartford, 1913.

$370 \mathrm{pp} ., 23^{\mathrm{cm}}$.

(Bulletin no. 20, Connecticut geological and natural history survey.) 



\section{CATALOGUE SLIPS.}

Bishop, Louis Bennett.

The birds of Connecticut. By John Hall Sage and Louis Bennett Bishop, assisted by Walter Parks Bliss. Hartford, 1913.

370 pp., $23^{\mathrm{cm}}$.

(Bulletin no. 20, Connecticut geological and natural history survey.)

Bliss, Walter Parks.

The birds of Connecticut. By John Hall Sage and Louis Bennett Bishop, assisted by Walter Parks Bliss. Hartford, 1913.

370 pp., $23^{\mathrm{cm}}$.

(Bulletin no. 20, Connecticut geological and natural history survey.) 



\section{CATALOGUE SLIPS.}

\section{Biology.}

Sage, J. H. The birds of Connecticut. By John Hall Sage and Louis Bennett Bishop, assisted by Walter Parks Bliss. Hartford, 1913.

370 pp., $23^{\mathrm{cm}}$.

(Bulletin no. 20, Connecticut geological and natural history survey.)

Birds.

Sage, J. H. The Birds of Connecticut. By John Hall Sage and Louis Bennett Bishop, assisted by Walter Parks Bliss. Hartford, 1913.

370 pp., $23^{\mathrm{cm}}$.

(Bulletin no. 20, Connecticut geological and natural history survey.) 



\section{State of Sonnecticut}

\section{PUBLIC DOCUMENT NO. 47}

\section{State Geological and Natural History Survey}

COMMISSIONERS

Simeon Eben Baldwin, Governor of Connecticut (Chairman)

Arthur Twining Findex, President of Yale University

William Arnold Shanklin, President of Wesleyan University

Flavel Sweeten Luther, President of Trinity College (Secretary)

Charles Lrwis Beach, President of Connecticut Agricultural College

SUPERINTENDENT

WILliam NORTH Rick

\section{Bulletin No. 20}

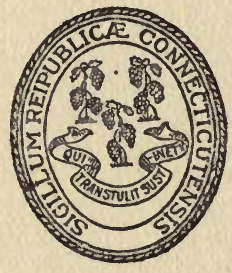

HARTFORD

Printed for the State Geological and Natural History Survey 


\section{Publication Approved by the BoARD of Control}

The Case, Lockwood \& Brainard Co.. Hartford, Conn. 


\title{
The Birds of Connecticut
}

\author{
By \\ JOHN HALL/SAGE, M.S. \\ Secretary of the American Ornithologists' Union \\ and \\ LOUIS BENNETT BISHOP, M.D. \\ Fellow of the American Ornithologists' Union \\ assisted by \\ WALTER PARKS BLISS, M.A.
}

HARTFORD

Printed for the State Geological and Natural History Survey 1913 



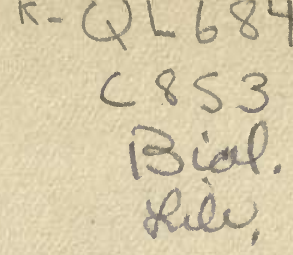

\section{Contents}

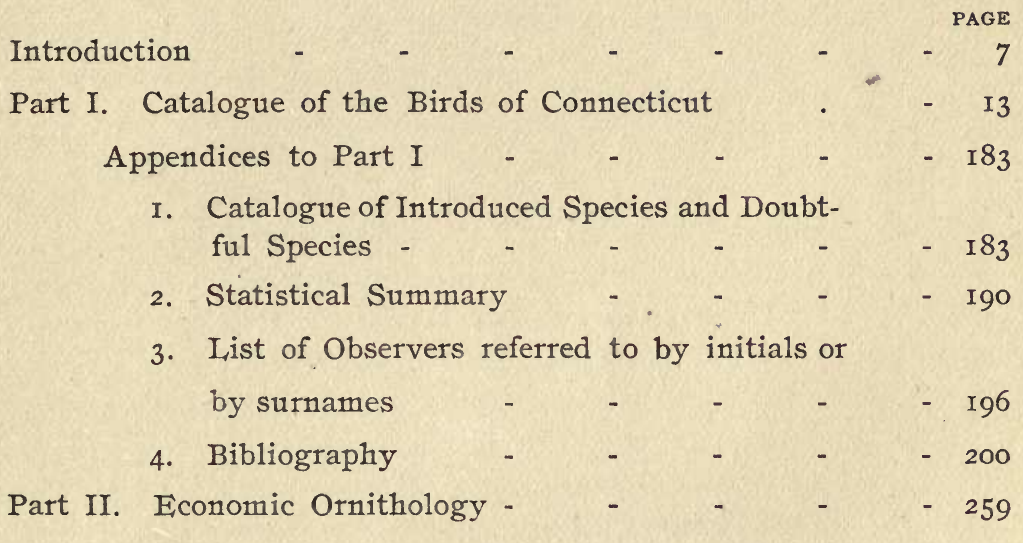





\section{Introduction}

Facing Long Island Sound for practically all of its hundred miles of southern border, Connecticut shows a succession of low, rocky promontories and sandy beaches divided by shallow bays and salt marshes. The latter stretch for varying distances northward, but soon give place to rather broad stream valleys, separated by gently rising hills. These hills, usually low and rounded at the coast, when not dikes or sheets of trap, as near New Haven, become rapidly more mountainous in the northwestern part of the state, culminating in Bear Mountain in the extreme corner, 2,354 feet in altitude and sixty miles from the Sound.

The soil of these hills is usually poor and shallow, while that of many of the valleys is deep and rich, so that, while the lowlands are well cultivated and thickly settled, the uplands are generally left to brush land or forest. From this configuration it will be evident that most of the streams are short and flow in a southerly direction. Three main river courses cross the state:- the Thames on the east, which for its lower quarter is practically an arm of the sea, and above that hardly more than a small stream; the Connecticut, which passes through the center, in a broad and fertile valley in its upper course, and in a narrow valley hemmed in by highlands below Portland; and the Housatonic in the western part, with a narrow and much more mountainous valley. Apparently the Connecticut and upper Housatonic valleys and the southern coast line are highways for the migration of our birds in spring, and the coast line certainly is in fall, but our information on this point is at present very incomplete.

The woodland consists chiefly of deciduous trees, though hemlocks and cedars are common, and groves of white pine and spruce still exist in the northwestern portion.

Shut off from the ocean by Long Island, strictly pelagic birds are seldom found in Connecticut, but for many other species it is particularly fitted as regards climate and topography. Over $\mathbf{1} 35$ 
species nest more or less regularly within its borders, and it is probable there are few localities in our country where so many can be found within so circumscribed an area. Almost the entire state lies in the Alleghenian Zone, where such birds as the Ruffed Grouse, Red-shouldered Hawk, Kingbird, Least Flycatcher, Bobolink, Baltimore Oriole, Goldfinch, Towhee, Indigo Bunting, Scarlet Tanager, Red-eyed, and Warbling Vireos, Black and White, Yellow, and Chestnut-sided Warblers, Catbird, Brown Thrasher, Chickadee,Wood, and Wilson's Thrushes, nest abundantly. Along the southern border and for some distance up the Housatonic and Connecticut valleys, the breeding, often in abundance, of such species as the Clapper Rail, Fish Crow, Acadian Flycatcher, Orchard Oriole, Seaside Sparrow, White-eyed Vireo, Wormeating, Blue-winged, Prairie, Hooded, and Kentucky Warblers, Louisiana Water-thrush, and Yellow-breasted Chat brings this district within the northern limits of the Carolinian Zone; while the occasional, and in some cases regular, breeding of the Canadian Ruffed Grouse, Goshawk, Yellow-bellied Sapsucker, Alder Flycatcher, Savannah, and White-throated Sparrows (?), Blue-headed Vireo, Black-throated Blue, Magnolia (?), Blackburnian, and Canadian Warblers, Winter Wren (?), Red-breasted Nuthatch, and Hermit Thrush, in the northwestern part of Litchfield County, shows at least strong Canadian elements in the avifauna, though it may not be enough to include that district in the Canadian Zone.

Interest in our birds must have existed among many in the earlier days of Connecticut, and scattered references to them may be found in many volumes; but the first definite list of the birds of the state was written by the Rev. James H. Linsley, of Stratford, ${ }^{1}$ and published in the American Journal of Science and Arts in 1843 . He recorded 302 species, but of these Dr. Merriam ${ }^{2}$ concluded that only 239 distinct species had been reported on satisfactory evidence. He recorded several birds that have not since been reported from our state, and some of his specimens are still in the Peabody Museum of Yale University, and others in the collection of the Bridgeport Scientific Society.

1 A Catalogue of Birds of Connecticut, arranged according to their natural families; by the Rev. James H. Linsley. Am. Jour. Sci. and Arts, vol. xliv, No. 2, pp. 249-74, April, 1843 .

${ }^{2}$ Merriam, Review of the Birds of Connecticut, p. 144. 
Thirty-four years later Dr. C. Hart Merriam prepared a list with copious and valuable annotations, which was published in the Transactions of the Connecticut Academy of Arts and Science in 1877..$^{1}$ This work is a model of its kind, but has been long out of print. Dr. Merriam was able to notice 29I species with good claims to inclusion in our avifauna; and of these several have not been taken since in our state.

Thirty-four years have again passed, during which enormous strides have been taken in the knowledge of the birds of our entire country. We wish we could say the knowledge of Connecticut ornithology had kept pace. But it has not. The birds of certain localities near the larger cities are well known, but there are still large districts - in fact the greater portion - of the state from which no records have reached us. Ornithologists in Connecticut are far too few, and many of them have little time to devote to this study; but all have responded most generously to our appeal for assistance, as the following pages will show. This list is based primarily on the notes and collections of Mr. Sage and Dr. Bishop, obtained through field work in Connecticut during the past 45 and 30 years respectively. The migration dates for Portland and New Haven, given without quotation of authority, are taken from their field notes, as are all other statements and dates for which the name of the authority is not cited. Practically all the other records from the western portion of the state and from New London were given to Dr. Bishop, either in the form of specimens, by notes, or by word of mouth, by the gentlemen to whom they are accredited; and he is entirely responsible for the chapter on Economic Ornithology. For the citation of most of the other published and unpublished records Mr. Sage is to be credited, while Mr. Bliss has found some in ornithological literature. To Mr. Bliss has fallen the task of tabulating Mr. Sage's records of the past 45 years, which press of other duties prevented Mr. Sage doing himself, searching ornithological works for records, preparing much of the bibliography, as well as the index, etc., and combining all the notes into as harmonious a whole as is possible in a work of this character.

For cordial cooperation and assistance our hearty thanks are due to Prof. A. E. Verrill, Dr. Leonard C. Sanford, Rev. Her-

${ }^{1}$ Review of the Birds of Connecticut with Remarks on their Habits, by C. Hart Merriam. Trans. Conn. Acad., vol. iv, pp. 1-150, July, 1877. 
bert K. Job, Harry W. Flint, J. B. Robertson, Clarence R. Hooker, Aretas A. Saunders, Clifford H. and Dwight B. Pangburn, Philip L. Buttrick, and Alfred W. Honywill, Jr., of New Haven; Lewis B. Woodruff and Prof. C. C. Trowbridge, of New York; William H. Hoyt, Louis H. Porter, and John Schaler, of Stamford; Dr. E. H. Eames, Henry W. Beers, and George L. Hamlin, of Bridgeport; Jesse C. A. Meeker, of Danbury; E. H. Austin, of Gaylordsville; $H$. Cornelius and Robert C. Judd, of Bethel; James H. Hill, of New London; Alanson Ganung, of West Haven; Willard E. Treat, of East Hartford; C. G. Hart, of East Berlin; and many others; who have contributed records of value. Mr. Walter R. Nichols, often mentioned in Dr. Merriam's catalogue, also gave his ready help, but him our thanks can no longer reach; and the same is true of the late Mr. E. Seymour Woodruff, whose initials appear so frequently in the following pages. A careful and conscientious observer, with wonderfully keen eyes and ears, an enthusiastic and able naturalist, a firm friend and a delightful companion, he was taken at the beginning of a most promising career, leaving all who knew him to mourn him. We wish also to add our tribute to the faithfulness and reliability of Judge John N. Clark, who died in I903, and whose letters and published records are often quoted in this Bulletin. A thorough and painstaking ornithologist, he did more perhaps than any one else to increase our knowledge of the breeding habits of certain birds along the southern border of Connecticut.

That this list is in many ways unsatisfactory and incomplete the authors realize all too well; but they hope that it may be a stimulus to others to fill up the gaps by conscientious collecting, never being satisfied with an "opera-glass record" of any species that is at all rare, or with which they are not perfectly familiar. Field-glasses are of great assistance in the study of the habits of birds, and in identifying species with which one is already familiar; but every field ornithologist knows that the play of light and shadow often distorts colors and size so that the bird in the hand may prove a very different species from what it appeared in the tree. Therefore records of species out of their accustomed habitat should always be received with doubt unless accompanied by the bird itself. No one need fear that 
such collecting will prevent a species from establishing itself in our state; for experience has shown that birds have their natural limits, within which alone they can rear young successfully, and that the reason any given species of North American bird does not nest with us is that for some cause it finds the conditions in the season of reproduction unfavorable, or that it is unable to survive our winters, unless it is destroyed for sport or millinery. The vain attempts of the Carolina Wren to obtain a foothold in southern Connecticut are a case in point. Practically all our exact knowledge of the usefulness of birds has been obtained by the labor of ornithologists, often undertaken without thought of pecuniary reward; and it seems the height of ingratitude and folly to impede their future work by the imposition of burdensome regulations regarding collecting, or to forbid collecting entirely, as has been done by some legislatures. For, if there is one thing that is evident to those who have done much field work in ornithology, it is that the collecting of birds and eggs for scientific purposes, even by boys, can never appreciably reduce their numbers, as long as they are protected from too much slaughter in the name of sport, and their eggs and young are guarded from cats, which probably do as much damage to the young of our small useful birds near our towns and cities as all other agencies combined. 

PART I

\section{Catalogue}

$$
\text { OF THE }
$$

\section{Birds of Connecticut}





\section{Catalogue of the Birds of Connecticut.}

\section{Order PYGOPODES. Diving Birds.}

Suborder COLymBI. Grebes.

Family COLYMBIDE. Grebes.

Colymbus holbœlli (Reinhardt). Holbœll's Grebe.

A rare winter resident of Long Island Sound from November to March ; very rare inland.

Earliest record. Portland, Oct. 30, 1895 .

Latest record. Portland, May 3, I889.

Connecticut records. Linsley recorded this species from Stratford ; ${ }^{1}$ Oct. 19, I860, Hartford, one shot (reported by Dr. Crary) ; Feb. 23, I875, Saybrook, one taken (J. H. S.); Feb. 21, 1885, New Haven (G. E. V., in Peabody Museum); spring, 1887 (?), Milford, one taken (in coll. of L. C. S.) ; May 3, 1889, one; April I4, I894, one; Oct. 30, I895, one, Portland (in coll. of J. H. S.) ; Nov. 16, 1895, Stony Creek, female taken (E. M. Cooper, in coll. of L. B. B.) ; Feb. 20, I899, Bridgeport, young male taken (J. H. Canfield, in coll. of Mr. Beers) ; Feb. 27, 1902, Saybrook, one taken (J. N. C.) ; Jan., I904, New Haven (in coll. of L. C. S.) ; April, 1904, Kent, one shot (recorded by H. K. J.);? Jan. 26, I905, Danbury, one picked up exhausted and kept some time (Bristol, recorded by J. C. A. M., now in coll. of L. B. B.) ; Feb. 6, 1908, Gaylordsville, one found alive (G. A. Clute, in coll. of L. B. B.) ; Dec. 28, 1909, one; Oct. 15, 1910, Portland, one (in coll. of J. H. S.).

Colymbus auritus Linnæus. Horned Grebe.

Formerly a common fall migrant and winter resident on Long Island Sound from October to May $;^{1}$ much rarer in recent years. Never common in the interior of the state.

1 Merriam, Birds of Conn., p. 137.

2 Job, The Sport of Bird Study, p. 288. 
Earliest record. New Haven, Sept. I2, I882; Portland, Oct. 19, 1877.

Latest record. New Haven, March 16, I894; Portland, May 3, 1889 .

Recent records. Nov. 6, 1905, Sept. 28, 1906, Litchfield (E. S. W.) ; Nov. 3, I906, Guilford (L. B. B.) ; Oct. 6, and Nov. 9, I906, Stony Creek (L. B. B.) ; May, I906, Litchfield (H. K. J.) ;1 Oct. 2I, I907, New Haven (A. A. S.) ; Feb. 25, 1909, Portland (J. H. S.).

Breeding records. Mr. Job believes a pair bred in Litchfield County in I906. The following specimens in breeding plumage are recorded for this state: North Haven, April 24, 1883; New Haven, May, I888 (L. C. S.) ; Portland, May 3, I889 (in coll. of J. H. S.) ; Stamford, May 8, I893 (in coll. of Mr. Porter).

The Horned Grebe has been recorded from the following inland localities: Haddam (J. H. S.) ; Litchfield (E. S. W. and H. K. J.) ; Melrose (C. A. Thompson) ; ${ }^{2}$ Portland (J. H. S.) ; East Hartford (W. E. T.).

Podilymbus podiceps (Linnæus). Pied-billed Grebe.

A common fall migrant in September and October on freshwater ponds and on the creeks of the tide-water marshes. Very rare in the spring.

Average fall migration. Sept. 15 - Oct. 20.

Earliest record. New Haven, Aug. 30, I895; Portland, Sept. Io, 1893 .

Latest record. New Haven, Oct. 25, I882; Portland, Nov. 22, 1893 .

Spring records. April 7, 1892, Stratford (C. K. A., in coll. of Bpt. Sci. Soc.) ; April 13, r895, and April 19, I905, Portland (J. H. S.) ; April I2-I4, I906, New Haven (A. A. S.) ; April 2-23, I9Io, West Haven (H. K. J.) ; May 6, I9ro, West Haven (L. B. B.).

Breeding records. E. H. A. informs us that he has seen this bird almost every month in the year on the ponds in Litchfield County, and believes that they breed there. Mr. N. D. Betts of Boulder, Colo., records ${ }^{3}$ seeing five adults on a pond in Wilton,

${ }^{1} \mathrm{Job}$, The Sport of Bird Study, p. 287.

$2 O$. and $O$., viii, $x$, p. 3 .

Bird-Lore, xii, 5, p. 199. 
Conn., July 2I, 1909, one of which was feeding four young. These young did not appear to be over five or six inches long, and must have been hatched at the pond. Merriam ${ }^{1}$ and Samuels ${ }^{2}$ both note that this species breeds within the state, though neither mentions any specific records.

\section{Suborder CEPPHI. Loons and Auks.}

Family GAVIID王. Loons.

Gavia immer (Brünnich). Loon. Great Northern Diver.

A common winter resident of Long Island Sound from November to May, the majority going farther south in the winter. Occasional on the inland waterways. Very rare in the summer.

Earliest record. New Haven, Nov. I0, 1883; Portland, Sept. 26, 1892.

Latest record. New Haven, May 24, I900, and I907 (C. H. P.) ; Portland, July 6, 1893.

Inland records. Portland, Dec. I, I874, Dec. 2, I877, Nov. 7 , I890, Sept. 26, I892, July 6, I893; Litchfield, Nov. 6, I905, and Sept. 28, 1906 (E. S. W.) ; Lake Waramaug, Litchfield County (no date given) ; East Hampton. ${ }^{4}$

Breeding records. Merriam notes ${ }^{4}$ that according to $\mathrm{Mr}$. W. G. Buell this species " has been known to breed on a pond at East Hampton." Mr. W. R. Nichols informs us that a pair bred at Lake Saltonstall in 1890 , since he saw the old birds with two young there the last of June or early in July of that year, and that the last previous record of their breeding on this lake was in 1878 .

Summer records. July 24, 1882, Goose Island, Long Island Sound, one pair (L. B. B.) ; July 6, 1893, Portland, one young female (J. H. S.).

Gavia stellata (Pontoppidan). Red-throated Loon.

A rather common winter resident along the coast from November to March. Very rare inland.

Earliest record. New Haven, Oct. 20, I883; Portland, Oct. Io, 1892 ; Branford, Oct. 7 , I908, an adult in summer plumage (L. C. S.).

1 Merriam, Birds of Conn., p. 137.

${ }^{2}$ Samuels, Birds of New England, p. $56_{3}$.

30 . and 0. , ix, 6, p. 76 .

${ }^{4}$ Merriam, Birds of Conn., p. 136. 
Latest record. New Haven, April 23, I887 (L. B. W.) ; Branford, April 30, 1888 (W. H. Gardner).

Inland records. Portland, Oct. Io, 1892 , a young female (in coll. of J. H. S.) ; Hartford, Nov. 20, I895, a young bird found alive on the street, probably after being caught in the electric wires in the fog.

Only rarely are birds taken in the full nuptial plumage, as most go north in March before assuming this dress.

Mr. Nichols informed Mr. Merriam ${ }^{1}$ "that he saw one as late as June 2, 1877."

Family ALCID瓜. Auks, Murres, and Puffins.

Subfamily ÆтHrinæ. Auklets, Murrelets, and Guillemots.

Cepphus grylle (Linnæus). Black Guillemot.

The only record for this species in Connecticut is that of a male, received by J. H. S, from Mr. Gurdon Trumbull, taken at Stony Creek in December, $1887 .^{2}$

Subfamily Alcine. Auks and Murres.

Uria lomvia lomvia (Linnæus). Brünnich's Murre.

An irregular and probably accidental winter visitor to Long Island Sound; found occasionally on the ponds in the interior of the state.

Usual visitation between Dec. I and Jan. I5.

Earliest record. Portland, Nov. 21, I90I; Rocky Hill, Nov. I8, 1893 (W. E. T.).

Latest record. Saybrook, Feb. 19, I878 (J. N. C.).

Records for Connecticut. Feb. 19, 1878, Saybrook (J. N. C.); Jan., 1884, Saybrook (Dr. Pratt); Jan. 7, 19, I89I, Stamford (Hoyt and Schaler); Jan. I3, I89I, common at Stony Creek (W. F. Davis) ; Nov. 18, I893, Rocky Hill (W. E. T.) ; ${ }^{3}$ Dec. II, 1894, Essex (E. Saunders); Dec. 14, 22, 1894, Portland (J. H. S.) ; Dec. 15, 1894, Stamford (Hoyt) ; Dec. 1894, Lake Saltonstall (A. J. G.) ; Jan. I, I895, Stony Creek (E. M. Cooper); Dec., I896, New Haven (L. C. S.) ; winter, I900-I, Saybrook (J. N. C.) ; Nov. 21, 29, Dec. I4, I90I, Portland (J. H. S.) ; Dec. 6, 
I90I, New Haven (C. A. Dorman) ; Dec., I901, Still River, Litchfield County (H. K. J.) ; Dec., 1907, Twin Lakes (C. S. Phelps). ${ }^{1}$ According to $\mathrm{C} . \mathrm{K} . \mathrm{A}^{2}{ }^{2}$ this species occurred in great numbers along the Connecticut coast during the winter of I890-I. Hoyt (Stamford) reported them plentiful there from Dec. 20 to Feb. Io of that winter, he himself seeing fourteen. At that same time D. C. Sanford reported "thousands of them" in the vicinity of the mouth of the Saugatuck River.

The Murre taken by Capt. Brooks near Faulkner's Island " about eight years ago" and recorded by Dr. Merriam as Uria troile is a bird of this species. ${ }^{3}$

This species was not recorded in Linsley's or Merriam's list.

\section{Alca torda Linnæus. Razor-billed Auk.}

The only Connecticut reference to this species is by Merriam, who merely states that it is " a rare winter visitor in the Sound ". 3

Specimens have since been recorded from points farther south (Cobb's Island and Norfolk, Va.).

\section{Subfamily Allinæ. Dovekies.}

\section{Alle alle (Linnæus). Dovekie. Little Auk.}

A rare winter visitant on the coast. Very rare inland.

Coast records. Nov. 25, 1874, Saybrook, picked up on beach after a severe storm (in coll. of J. H. S.) ; Nov. 26, 1877, Morris Cove, New Haven (in Peabody Museum) ; Oct., I879, two, Guilford (in Peabody Museum) ; Jan. I5, I89I, Stony Creek (in coll. of J. H. S.) ; Feb. I6, I894, Stony Creek (in coll. of Mr. Porter); c. Dec. Io, I893, Stonington. ${ }^{4}$

Inland records. Nov. Io, I849, Portland (Wood); Nov., I871, Middletown (G. B. Goode) ; Sept., I874, Wallingford (W. F. Lane) ; Dec. 7, 1877, Portland (W. W. C.) ; Nov. 23, 1878, Pomfret, blown inland during severe gale (in coll. of C. M. Jones). ${ }^{5}$

$1 \mathrm{Job}$, The Sport of Bird Study, p. 289.

2 C. K. Averill, $A u k$, viii, 3, pp. 307-8.

- Merriam, Birds of Conn., p. 138.

${ }^{4} N$. Y. Tribune. Dec. 10, 1893.

5 . and $O$., viii, 4 , p. 32. 
Order LONGIPENNES. Long-winged Swimmers.

Family STERCORARIIDE. Skuas and Jaegers.

Stercorarius parasiticus (Linnæus). Parasitic (or Richardson's) Jaeger.

Merriam refers to this species as a "rare winter visitor." Linsley notes it from Bridgeport.

Taken at Portland, fall of 1875 (J. H. S.) ; at Noank, Sept. 10, 1903 (Dr. C. B. Graves, in coll. of J. H. S.).

Stercorarius longicaudus Vieillot. Long-tailed Jaeger.

The only record of this species appears in Merriam's Birds of Connecticut, p. I3I. "I have just received from Wm. F. Lane, a beautiful adult specimen of this Larine plunderer, which he shot on the Community Lake at Wallingford, Conn., Aug. 3oth, I873."

\section{Family LARIDÆ. Gulls and Terns.}

Subfamily Larinæ. Gulls.

Rissa tridactyla tridactyla (Linnæus). Kittiwake.

A very rare winter visitant on the coast.

April 2, 1880, large numbers in the Thames River, Norwich (S. T. H.) ;2 Nov. 15, I883, one brought to the Peabody Museum and seen in the flesh by L. B. B.; Dec. 3, I884, one seen alive at West Haven by L. B. B.; Dec. II, I886, and March I9, I887, seen at New Haven by L. B. W.; Jan. 2I, I895, a young male taken at Stamford (in coll. of Mr. Schaler).

\section{Larus leucopterus Faber. Iceland Gull.}

The only record for Connecticut is a young male which was shot by a fisherman between Rye and Stamford, March 3, I894, and is now in the collection of L. H. Porter. ${ }^{3}$

Larus kumlieni Brewster. Kumlien's Gull.

A young female in the collection of $\mathrm{Mr}$. Porter was shot in Stamford Harbor, Feb. 16, 1894.

1 Merriam, Birds of Conn., p. 13 r.

$O$. and $O ., v i, 4$, p. $3 \mathrm{I}$.

? $A u k$, xii, 1, p. 76 . 
Larus marinus Linnæus. Great Black-backed Gull. A rather rare and very shy winter resident of the Sound. Earliest record. New Haven, Nov. IO, I883, Oct. II, 1886 (L. B. W.).

Latest record. New Haven, Jan. 19, I895, April 2, I887 (L. B. W.).

\section{Larus argentatus Pontoppidan. Herring Gull.}

An abundant winter resident on the Sound and along the inland waterways.

Earliest record. New Haven, Aug. 14, 1883; Portland, Oct. 6, 1892.

Latest record. New Haven, May 24, I900; Portland, April 20, 1908.

During the day these birds are abundant in New Haven Harbor, but the majority do not sleep there, for they may be seen flying west along the coast toward sunset and returning from that direction about sunrise.

Small flocks may often be seen during the migration in May flying high in an easterly direction and at some distance inland. A large flight, estimated at over 1,000 birds, in flocks of from three to twelve individuals, was seen at Hartford, March 20, I889, by W. E. Treat.

Larus delawarensis Ord. Ring-billed Gull.

A rare fall migrant on the coast.

Connecticut records. Nov. 29, 1886, West Haven (L. B. W.) ; Oct. 19, 1893, Stamford (in coll. of Mr. Porter); Dec. 6, I893, Stamford (in coll. of Mr. Schaler); Dec. 4, 1896, Stony Creek (J. E. Cooper, in coll. of L. B. B.) ; Oct. 23, 1905, Oct. 7, I908, Branford (L. C. S., the latter in coll. of L. B. B.).

Merriam asserts that it is not rare and that the young of this species may frequently be seen in the winter associated with $L$. argentatus. $^{1}$

Larus atricilla Linnæus. Laughing Gull.

At present only an accidental summer visitor. Never common.

Linsley found it at Stonington. Mr. Osborne informed Dr. Merriam that he had seen one, June I, $1876 .{ }^{1}$ 
The only recent record is that of L. C. S., who saw an adult in breeding plumage, followed by a young bird, at Branford, Sept. I, 1904 .

\section{Larus philadelphia (Ord). Bonaparte's Gull.}

A rather rare late fall migrant and occasional winter resident on the Sound. Rare inland.

Earliest record. New Haven, Nov. IO, I883, Oct. I I, I889 (L. B. W.) ; Stamford, Sept. I5, I904 (Schaler).

Latest record. New Haven, Dec. 29, I884, Jan., I887 (E. F. Coe).

Inland records. Litchfield, July I, I892 (examined by L. B. W. and E. S. W.) ; Sept. 24, I895, four (E. S. W.) ; April, 1905 (in coll. of Litchfield Sci. Soc.) ; Haddam Neck, Nov. I7, I900 (in coll. of J. H. S.) ; Wallingford, fall, I874 (eight seen by W. F. Lane). ${ }^{2}$

Summer records. Litchfield, July I, I892;1 Saybrook, Aug. 8, I896 (A. Taylor, in coll. of J. H. S.).

Formerly "quite common about Faulkner's Island, Conn., in October and November" and occasionally seen " at Goose Island in the summer". 2

\section{Subfamily Sterninæ. Terns.}

Sterna hirundo Linnæus. Common Tern.

A rather rare though formerly common ${ }^{3}$ summer resident, breeding in a few small colonies on islands in the Sound and in the extensive salt marshes of the eastern part of the state.

Breeding sites. Prior to I898, when the Government took over Great Gull Island on Long Island Sound for coast defense fortifications, this island was the location of a colony of 7000 terns. Since their dispersion at this time they have taken all the available islands off the Connecticut shore for nesting sites, where from one to a dozen pairs may be found every season. These include Goose I. (near Faulkner's I.), Duck I. (near Saybrook), Goose Rock (south of Niantic), Waterford I. (Niantic Bay), Two Tree I. (Millstone Point), Liddy's I. and Rocky I. (near Stonington) (Hill). A few formerly bred on Goose Island. ${ }^{3}$ 
On the mainland also this species occasionally breeds. L. B. B. found about twenty-five pairs breeding on the salt marshes at the mouth of the Hammonasset River, Clinton, June 23, 1904. Another colony of a dozen pairs was found at Grove Beach, Clinton, June 16 , I900, by Messrs. J. B. Canfield and C. H. Watrous.

Nest. The eggs are either laid on the sand of the beach or in hollows in the drift seaweed lying on the wet salt marsh.

Eggs, 2 to 5 ; average set, 3 .

Nesting dates. Earliest record, May 25, 1900, three eggs (Hill). Latest record, July 24, I882, one egg (L. B. B.).

In the fall migration this tern is occasionally common in the western part of the Sound. Mr. Hoyt reported them abundant at Stamford in August, I894. L. B. B. saw them in West Haven as late as Sept. 20, I889, and Sept. 27, I901.

Sterna paradisæa Brünnich. Arctic Tern.

In 1876 Merriam recorded the Arctic Tern as "a rare visitor to our shores". The only specific reference to its occurrence in Connecticut is from J. N. C. of Saybrook, who wrote: "I have an undoubted specimen in the fall plumage of the young, taken here last season - never captured a mature bird." 1

Sterna dougalli Montagu. Roseate Tern.

Formerly an abundant summer resident. At present, very rare.

On Goose Island, about one mile from Faulkner's Island, a colony of several hundreds of these birds was carefully protected by Capt. O. N. Brooks, the keeper of the Faulkner Light, until he resigned in 1883 . It is of this colony that Merriam writes: "They cover the rocks, almost hiding them from view. . . The eggs were now hatching and thousands of downy young covered the island." 2 This colony was visited by L. B. B. in the summer of I88I, I882, and I883, when many eggs were found and numerous birds seen, but in 1884 not a bird was to be seen and the ground was strewn with fresh or broken eggs. Practically the entire colony had been killed by a taxidermist soon after the birds had settled there for the summer. A few returned to the island the following year, when L. B. B. found one nest with two eggs and 
four with one egg each, but these terns are no longer common anywhere along the coast. The last record is a set of five eggs from Goose Island in 1888.

According to Hill, a few still breed with the Common Terns on the different islands, though he has not identified any eggs as positively belonging to this species.

The Roseate Tern was formerly common also in Stamford Harbor, though it is not found there now (Hoyt).

\section{Sterna antillarum (Lesson). Least Tern.}

Formerly common in certain localities along the coast. No . recent records.

J. N. C. reported them as quite abundant at Saybrook during migrations. ${ }^{1}$ (This was prior to 1876 .) Linsley took it at Stratford. ${ }^{1}$ They were also formerly common at Stamford Harbor according to Hoyt, but never occur there at present.

Sterna fuscata Linnæus. Sooty Tern.

The following records appear from Connecticut: 1876, Saybrook, picked up stunned by concussion with a wharf depot (in coll. of J. N. C.) ; Sept., I876, two adults killed themselves by flying against the Faulkner Light (one in coll. of Capt. Brooks) ;2 summer, 1876, specimen killed with a stone by Mr. E. Coe, Stony Creek ;2 Sept. 20, I876, specimen taken at Granby ;2 Sept. 16, I878, a young male knocked down with an oar in Stamford Harbor (in coll. of Mr. Porter) ; Oct., I89I, one found dead in the woods at Torrington after a severe storm. ${ }^{4}$

Hydrochelidon nigra surinamensis (Gmelin). Black Tern.

A rare visitor, usually late in August.

Connecticut records. Aug. 25, I891, Stamford, a young female (in coll. of Mr. Porter); Aug. 29, 1892, Little River Marshes, Middletown, four, one secured (in coll. of J. H. S.) ; Aug. 24, I893, Milford, two shot; ${ }^{5}$ Aug. 29, I893, Quinnipiac Marshes,

I Merriam, Birds of Conn., p. 134.

3 Merriam, Birds of Conn., pp. 134-5.

Auk, xii, I, p. 86.

4 Job, The Sport of Bird Study, p. 289.

- Forest \& Stream, xli, p. 250. 
New Haven, a flock of between thirty and forty, probably driven from their course by a southeast gale (L. B. B.) ; fall, I899 (?), Old Park Pond, Winsted, ${ }^{1}$ one seen; Sept. 6, I909, Hammonasset Marshes, Clinton, one young shot (C. R. Hooker, in coll. of L. B. B.). Dr. Merriam records it as a rare visitor, noting but two specimens, one taken near Goose Island by Capt. Brooks (about I864), another shot late in August at Milford. ${ }^{2}$

\section{Family RYNCHOPIDÆ. Skimmers.}

\section{Rynchops nigra Linnæus. Black Skimmer.}

One was taken near the Yale boat-house in New Haven Harbor about June 16,1883 , and was identified, June 18 , by L. B. B. Judge John N. Clark wrote J. H. S., Nov. 8, 1894: "A Black Skimmer was killed here (Saybrook) a few days ago."

\section{Order TUBINARES. Tube-nosed Swimmers.}

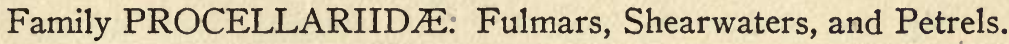

\section{Subfamily Fulmarine. Fulmars.}

Fulmarus glacialis glacialis (Linnæus). Fulmar.

A single bird of this species was shot by A. H. V. at the Thimble Islands, Stony Creek, Oct. 10, 1909, and brought to L. C. S. in the flesh. It is now in the collection of L. C. S. This is the only record for Connecticut, except the doubtful reference in Linsley's list, of which Merriam does not consider he had sufficient proof. $^{3}$

Subfamily Pufrinine. Shearwaters and Petrels.

Puffinus gravis (O'Reilly). Greater Shearwater.

According to Merriam (I876), "not rare in winter off the coast, but generally keeps outside the Sound." Linsley recorded it as common about Stonington. Merriam further notes that " in the Museum of Wesleyan University at Middletown is the head of a bird of this species which is said to have been killed at Granby, Conn."'

$1 \mathrm{Job}$, The Sport of Bird Study, p. 290.

2 Merriam, Birds of Conn., p. 135.

- Merriam, Birds of Conn., p. 146.

- Merriam, Birds of Conn., p. 136 . 
Subfamily Procellarinne. Storm Petrels.

Oceanodroma leucorhoa (Vieillot). Leach's Petrel.

Pelagic. Rarely seen within the limits of this state.

Connecticut records. Oct. 27, I857, one shot by Geo. Meigs on the Connecticut River above Hartford ; 1 Merriam also records (1876) that he himself has "twice seen it on the Sound in the vicinity of Faulkner's Island, and near New Haven;" Sept. 17, 1903, a female picked up in Middletown, driven inland by a terrific storm; Oct. 18, 1904, a specimen killed in Portland (both the latter in coll. of J. H. S.) ; Oct., I904, one taken by Mr. James Truelove on Lake Wononscopomus, Lakeville (in coll. of L. B. B.). Mr. Wm. Hansen reports seeing a mounted bird which was found dead in Torrington, Sept., 1902. ${ }^{2}$

Subfamily Oceanitine. Long-legged Storm Petrels.

Oceanites oceanicus (Kuhl). Wilson's Petrel.

We have no specific records of this species. Merriam characterizes it as "not common; occurs off the coast in summer.", Linsley says that he has seen this species " not only in our Sound, but even west of Stratford." 3 Mr. Holt of Lyme told W. E. T. that this species "occasionally flies over land and is usually seen hovering over fern bushes" (J. H. S.).

About a dozen petrels, almost certainly of this species, were seen in Long Island Sound not far from the mouth of New Haven Harbor, Aug. 5, I9I I, by L. B. B. ; and to this species should probably be referred three petrels seen by Mr. Edward Everit near Branford Beacon, June 20, 1909.

\section{Order STEGANOPODES. Totipalmate Swimmers.}

\section{Family SULID瓜. Gannets.}

Sula leucogastra (Boddaert). Booby.

The only record of this species in Connecticut is one taken at Guilford by Linsley." Merriam refers to it as "a rare and accidental visitor from the South."

${ }^{1}$ Merriam, Birds of Conn., pp. $135-6$.

$2 J o b$, The Sport of Bird Study, p. 290.

- Merriam, Birds of Conn., p. 136 .

- Merriam, Birds of Conn., p. 130. 
Sula bassana (Linnæus). Gannet.

A very rare winter visitant. The following references are found in Merriam:1 Capt. Brooks of Faulkner's Island has seen two of this species, one of which "was killed at Guilford in the spring about ten years ago" (i. e., about I866), and is now in his collection. Linsley took it at Stratford (now in Peabody Museum). Both these birds are in juvenile plumage. Mr. Robert Morris saw an adult specimen shot off Branford late in the fall of 1872 or 1873 .

\section{Family PHALACROCORACIDA. Cormorants.}

\section{Phalacrocorax carbo (Linnæus). Cormorant.}

A very rare fall migrant on the Sound. Formerly a "tolerably common winter visitant." 2

Capt. Brooks wrote Merriam that they were plentiful in April and May, and were sometimes seen in the fall. Linsley took this species at Stonington.

The only recent record is that of a young bird shot at Branford, Nov. 22, 1904. It is now in the collection of L. C. S.

Phalacrocorax auritus auritus (Lesson). Double-crested Cormorant.

A rare spring and fall migrant on the Sound, though apparently more common than $P$. carbo; very rare inland.

Spring records. Linsley records a specimen from Stratford which is in nuptial plumage (in coll. of Bridgeport Hist. Soc.) ; May, 1876, Capt. Brooks saw "large flocks of them feeding about Faulkner's Island";2 April 30, 1888, one taken at Branford by W. H. Gardner (now in Peabody Museum) ; June 8, 1892, three seen at the mouth of Connecticut River by J. H. S.; April 29, I896, one from a flock of six taken at New Haven (seen in the flesh by L. B. B.) ; May 7, I89I, Guilford (H. W. F., now in coll. of Wm. Brewster).

Fall records. Oct. 29, I875, one killed in Connecticut River at Portland (in coll. of W. W. C.) ; Oct., I879, one shot at Bolton (in coll. of W. W.) ; Nov. IO, I883, a small flock seen off Guilford

1 Merriam, Birds of Conn., p. 129.

2 Merriam, Birds of Conn., p. 130. 
by L. B. B. ; Oct. 23 , 1890, one adult seen at Little River Marshes, Middletown, by W. E. T. and S. R.; Nov. 2, 1890, one seen at Hartford by W. E. T.; Sept. 25, 1904, a flock seen on the beacon in Branford Harbor by G. E. V.; Oct. 17, I908, a young male shot at Double Beach, Branford, by C. R. Hooker (in coll. of L. B. B.).

Summer record. July I8, 1906, Madison, two seen (A. A. S.).

Inland records. Portland, Oct. 29, I875 (see above); Bolton, Oct., 1879 (see above) ; Middletown, Oct. 23, 1890 (see above) ; Hartford, Nov. 2, 1890 (see above).

\section{Family PELECANIDÆ. Pelicans.}

Pelecanus occidentalis Linnæus. Brown Pelican.

The only record of the Brown Pelican in Connecticut is that of an apparently uninjured specimen caught alive off Guilford Harbor, June 6, I902, by Mr. Levi Thrall, who reported that it seemed unable to fly far, so that he easily caught it by chasing it in a rowboat. L. B. B. saw it in the flesh. It is at present in the collection of L. C. S.

Family FREGATID压. Man-o'-war-birds.

Fregata aquila (Linnæus). Man-o'-war-bird.

The only record of this species in Connecticut (noted both in the American Naturalist and in Merriam's Birds of Connecticut), 1 is that of Capt. Brooks, who killed a female on Faulkner's Island in the autumn of 1859 , while it was hovering over the island. It is still in the collection of Capt. Brooks (L. B. B.).

\section{Order ANSERES. Lamellirostral Swimmers.}

Family ANATIDAE. Ducks, Geese, and Swans.

Subfamily Mergrnæ. Mergansers.

Mergus americanus Cassin. Merganser.

A tolerably common winter resident from December to February, frequenting fresh-water lakes and inland waterways.

Earliest record. (Coast) Clinton, Dec. 2, 1898; (Inland) Portland, Dec. 3, I 888.

Latest record. (Coast) Stamford, Feb. 25, 1898; (Inland) Portland, April 23, 1904. (J. H. S. records this species at Portland as late as April, in 1875, 1887, 1899, 1904, and 1909.) 
Unusual records. June 26, I888, Portland (J. L. Goff) ; July 3I, I879, Portland (J. H. S.).

H. K. J. reports the Merganser as a fairly common migrant and winter resident in Litchfield County between November and April. $^{1}$

Mergus serrator Linnæus. Red-breasted Merganser.

A rather common winter resident on the Sound from November to March; occasional inland.

Earliest record. New Haven, Oct. 21, 1882.

Latest record. New Haven, April 4, 1895.

Inland record. Portland, Nov. 9, 1884 (in coll. of W. W. C.).

Lophodytes cucullatus (Linnæus). Hooded Merganser.

A rare and irregular spring and fall migrant.

Spring migration. Earliest record. Portland, March 6, 1876. Latest record. Portland, April I, I899.

Fall migration. Earliest record. Litchfield, Sept. 15, 1905 (L. S. W.). Latest record. Portland, Dec. 5, 1887.

Several specimens of the Hooded Merganser have been shot in the Quinnipiac Marshes (North Haven) and in Lake Saltonstall (East Haven) ; viz., Jan. 9, I883, one (L. C. S.) ; Oct., I885, three young (L. C. S.) ; Nov. I4, 1904, two young (A. J. G.) ; March, 1904, one (A. J. G.) ; March, 1904, several (Devine) ; March 20, I907, two (Uhl); Nov. II-I3, I908, seven (Haines, in coll. of L. B. B.).

H. K. J. reports that Mr. C. H. Williams "saw a female with young in Winchester about fifteen years ago" $(c .1893){ }^{1}$

Dr. William Wood of East Windsor Hill wrote in 1880 : "It is not common here, yet some seasons I get half a dozen or more, and then several seasons may intervene before anather is captured." 2

There is a male of this species in the collection of J. M. W. shot on a pond in Canterbury late in October, $1880 .^{3} \mathrm{Mr}$. J. Y. Stetson of New Haven has an adult male which he shot from a pair at Neversink Lake, Danbury, late in March, about 1885.

- 1 Job, The Sport of Bird Study, p. 290.

$2 O$. and $O ., \mathrm{v}, 12, \mathrm{p} .93$.

s $O$. and $0 ., \mathrm{v}, 10, \mathrm{p} .78$. 
Subfamily Anatin w. River Ducks.

Anas platyrhynchos Linnæus. Mallard.

Formerly a rare fall migrant on the coast, but much more common in recent years; occasionally a winter resident.

Earliest record. New Haven, Oct. 25, 1904.

Latest record. New Haven, Jan., I897, and 1899 (L. C. S.); Clinton, March 27, I889 (J. F. Parker).

This species probably occurs regularly on the Quinnipiac Marshes and Lake Saltonstall (where L. B. B. and others have obtained many records), as well as along the Connecticut River.

Merriam $^{1}$ characterizes the Mallard as a " rare migrant." $\mathrm{He}$ notes their occurrence Sept. 30, Oct., and Nov. I3, 1875, and the observations of Grinnell in October and November, I876. $\mathrm{Mr}$. Hoyt states one was taken in Stamford in the fall of 1879 . C. M. Jones of Eastford records ${ }^{2}$ a pair shot in Eastford, Oct. 30, I882, adding that it "is the first time I have ever known of this species occurring here." The first records for New Haven were November 5, I883, when L. B. B. reported three taken in the Quinnipiac Marshes, and Aug. 4, 1886, when E. L. Munson ${ }^{3}$ took an adult male at the same locality. However, since that time the Mallards have been increasing, so that recent records are quite numerous for this species in Connecticut.

Judge Clark reported an unusual flight at Saybrook in the winter of I9OI-2, saying he had seen more that winter than in the rest of his life.

Anas rubripes Brewster. Black Duck.

A common fall and tolerably common spring migrant and winter resident; rare summer resident.

Spring migration. Earliest record, Portland, March Io, 1878. Latest record, New Haven, June 27, 1884; Portland, May I I, 1908.

Fall migration. Earliest record, New Haven, Sept. 16, 1904; Portland, Sept. I4, I877. Latest record, Portland, Nov. 8, 1892.

Winter records. Portland, Dec. 9, 1896, Jan. 2, 1906. Winters at New Haven.

${ }_{1}$ Merriam, Birds of Conn., p. 123.

$2 O$. and $O$., viii, 4, p. 32 .

: $O$. and $O$., xii, 9, p. 156 . 
Nest. Eggs laid on bank of a stream, in a meadow, or in a thicket, some distance from the water.

Eggs. Usually 9 (II).

Breeding records. May I2, I898, nine eggs, and June 8, 1899 , nine eggs, New London (Hill) ; May 20, I90I, eleven eggs, Kent (H. K. J.) ; April 22, 1904, five eggs, incomplete, Kent (Austin). At Saybrook Judge Clark found two nests of this duck.

Fall migrants reached Litchfield on Sept. 7, 1905 (E. S. W.).

Chaulelasmus streperus (Linnæus). Gadwall.

Very rare.

Merriam ${ }^{1}$ states that it occurs during migrations, though not common (1876). At that time Capt. Brooks wrote Merriam that these birds were "occasionally seen" about Faulkner's Island. Linsley wrote that "flocks of the Gray Duck were here as early as August last season" (1842). One was shot at East Hartford, Nov. 5,1883 (W. E. T.).

The only recent records are those of $\mathrm{H}$. K. J., who heard of two being shot at Twin Lakes about the middle of November, $1907,{ }^{2}$ and states that Mr. W. A. Miles has killed others there; and the two young males taken on the Quinnipiac Marshes (North Haven), Oct. 12, 1912, by A. and W. Ganung (in coll. of L. B. B.).

\section{Mareca americana (Gmelin). Baldpate.}

A rare winter resident on the Sound from October to March.

Earliest record. Quinnipiac Marshes, New Haven, Oct. II, I909 (A. Ganung).

Latest record. Clinton, March 27, 1899 (J. F. Parker).

Inland records. Hamden, Oct. 16, 1880 (Woolsey, in coll. of Peabody Museum); Middletown, fall, I882, five out of a flock of seven killed by J. Taylor (J. H. S.) ; Portland, April, I883, a male shot (J. H. S.) ; Portland, Oct. 23, I888, a female shot by J. L. Goff (in coll. of J. H. S.) ; Bantam Lake, Litchfield, one shot Oct. 20, 1904, and another, Oct. 20, 1905, by H. Sanford (E. S. W.). 
Besides these records a number of birds have been taken at Lake Saltonstall and in the Quinnipiac Marshes, the majority of which are in the collections of L. C. S. and L. B. B., in addition to a few birds taken at Branford, Clinton, and Stony Creek.

Merriam ${ }^{1}$ mentions this species as " not particularly rare during the migrations." It was taken by Linsley at Stratford, and one by Dr. Wood at East Windsor Hill.

Nettion crecca (Linnæus). European Teal.

Very rare in North America. The only Connecticut reference is furnished by W. E. T. of East Hartford, who received from a * resident gunner a fine adult male, shot Nov. 14, 1889, while flying with another, apparently of the same species, over an open field. It is now in the collection of J. H. S. ${ }^{2}$

Nettion carolinense (Gmelin). Green-winged Teal.

A tolerably common fall and rare spring migrant, and a rare winter resident.

Fall migration. Earliest record. New Haven, Sept. 3, 1886; Portland, Sept. 27, 1903; Litchfield, Sept. 8, I906 (E. S. W.). Latest record. New Haven, Oct. 16, I883; Portland, Nov. 27 , 1896.

Spring records. April 8, I874, and April 6, 1887, Portland (J. H. S.) ; March 21, I896, Stony Creek (E. M. Cooper, in coll. of L. B. B.) ; March 8, 1899, Clinton (J. F. Parker, in coll. of L. B. B.) ; "Have seen it in March" (Merriam). ${ }^{1}$

Winter record. Jan. I4, I902, one taken in Branford Harbor by Mr. J. Lanfear (in coll. of L. C. S.).

Querquedula discors (Linnæus). Blue-winged Teal.

A tolerably common fall and rare spring migrant.

Fall migration. Earliest record. New Haven, Sept. I, 1886; Portland, Sept. 8, 1897. Latest record. New Haven, Sept. 20, 1896; Portland, Oct. 17, 1874.

Spring records. April I4, I896, Quinnipiac Marshes (A. R. Andrews, in coll. of L. B. B.) ; April 9, 1902, Portland; April 27, I905, West Haven (W. L. Ganung, in coll. of L. B. B.).

${ }_{1}$ Merriam, Birds of Conn., p. 124.

${ }^{2}$ W. E. Treat, $A u k$, viii, I, p. II2. 
Unusual record. July 26,1890 , Quinnipiac Marshes, seen by Prof. C. C. Trowbridge and L. C. S.

Spatula clypeata (Linnæus). Shoveller.

A very rare migrant along the coast.

Connecticut records. March 20, 1854, two full-plumaged males taken at Lyme by Horace Champion (formerly in coll. of J. C. Comstock) (J. H. S.) ; Dec. 8, 1874, specimen shot by Mr. Pease at Saybrook (in coll. of W. W. C.) ; Oct. 8, 1875, two or three, near Milford (Grinnell) $;{ }^{1}$ Oct. 29, 1886, four taken in West Haven (formerly in coll. of L. C. S.) ; Nov. 27-30, 1893, a flock frequented the Quinnipiac Marshes (A. R. Andrews and E. Mitchell); Oct., 1894, one taken in Stamford (in coll. of Hoyt). Linsley obtained two males at Stratford ${ }^{1}$ (in Linsley Coll. of Bpt. Sci. Soc.); has been taken at Twin Lakes (Miles). ${ }^{2}$

\section{Dafila acuta (Linnæus). Pintail.}

A rare straggler in the fall.

Coast records. Quinnipiac Marshes, one, Sept. 26, 1883 (in coll. of L. B. B.) ; flock of seven, Sept. 28, 1907 (J. Y. Stetson); two, Oct. 23, 1909 (A. Ganung, in coll. of L. B. B.) ; West Haven, Oct. 13, 1906, seven seen (A. Ganung, one in coll. of L. B. B.) ; one, Oct. 22, 1906 (E. S. W.) ; Stratford, Nov. 10, 1889 (in coll. of Bpt. Sci. Soc.); Stamford, about 1890 (Schaler); Stratford, (Linsley) ; Saybrook (J. N. C.), not particularly rarę (1876). ${ }^{3}$

Inland records. East Windsor Hill, two (in coll. of Dr. Wood, I876) ;3 Portland, Oct. 9, I89o, a young male killed (Parkinson, in coll. of J. H. S.) ; Middletown, Oct. I2, I89I, four seen, one shot (W. E. T. and S. R., in coll. of J. H. S.) ; Oct. I8, 1893, four seen by same; Essex, Jan. 22, 1894, fifteen seen, two shot (in coll. of J. H. S.) ; Torrington, Oct. 25, 1907, one shot (Hanson) ;2 Twin Lakes (Miles). ${ }^{2}$

Aix sponsa (Linnæus). Wood Duck.

A summer resident, breeding throughout the state but becoming more rare each year.

1 Merriam, Birds of Conn., pp. 124-5.

$2 \mathrm{Job}$, The Sport of Bird Study, p. 291.

Merriam, Birds of Conn., p. 123 . 
Earliest record. New Haven, March 21, 1884; Portland, March 20, 1879. I888.

Latest record. New Haven, Nov. 17, I883; Portland, Dec. 3,

Nest. Usually located in a hollow tree at a height of from eight to thirty feet from the ground.

Eggs. Nine or ten; the last of May.

Nesting dates. Earliest record. May I4, I900 (H. K. J.). Latest record. July 2, 1904 (J. C. A. M.).

Breeding records. c. May 28, I875, Portland, nest with I4 eggs (J. H. S.) ; May 24, I885, Hamden, nest with 9 eggs (R: Morley) ; June 18, 1891, Chester, a set of Io eggs (Watrous, in coll. of H. W. F.) ; May I4, I900, Kent, Io eggs in a hay-loft of an old barn (H. K. J.) ; May, Igor, East Lyme, nest with 9 eggs (Way) ; July 2, 1904, Litchfield, nest with Io eggs (J. C. A. M.).

\section{Subfamily Fuliguline. Sea Ducks.}

Marila americana (Eyton). Redhead.

A very rare bird until recent years, when it seems to have occurred quite regularly as a winter visitant.

Merriam ${ }^{1}$ refers to this bird as "rare," noting that it has been taken at Westbrook (prior to I876). Linsley took it at Stratford. At Stamford it has been seen frequently in the Sound, and one was taken in the winter of 1886 (W. H. H.). The next record is that of Mr. Holt of Saybrook, who says he shot twenty-eight in 1889, while he later records two or three flocks there, Oct. 19, I893. Four were taken at Lake Saltonstall, Dec. 20, I897, by A. J. G., and one at Stratford, Dec., I897, by J. Locke.

However, since 1902, the species has become more common, and we have records from Branford, Dec., Igor, Jan. 6, Nov. 15, 1902, March, 1904 (L. C. S.), and Jan. I, 1901 (Locke); Lake Saltonstall, East Haven, Oct. 25, 1902, Dec. 22, 1903 (A. J. G.), April 3, 1907 (A. A. S.) ; West Haven, April 2, 1910 (H. K. J.) ; Litchfield, Nov. 3, 6, I905 (H. Sanford); Portland, Oct. 29, I903, Oct. 16, 1906, Nov. 26, 1907, Nov. 26, 1909 (J. H. S.).

Marila valisineria (Wilson). Canvas-back.

A very rare accidental winter visitor.

1 Merriam, Birds of Conn., p. 125. 
Connecticut records. 1876, Merriam $^{1}$ records this species as "rare"; May 7, 1876 , one seen by $R$. Morris in New Haven (?) ; J. H. Hand reports it "very rare" at Westbrook, I876; Linsley took it at Stratford ; ${ }^{1}$ March 20 , I887, a flock reported seen at Lake Saltonstall by Mr. Folsom; I889, two reported killed at Saybrook by Mr. Jas. Holt; fall, I894, one reported taken at Stony Creek by E. M. Cooper (?); Nov., I896, one shot from a flock at Twin Lakes by W. A. Miles;2 Jan., 1902, two males taken at Lake Saltonstall by A. J. G. (in coll. of L. C. S.) ; April I, I904, one male taken at North Branford (in coll. of L. C. S.).

Marila marila (Linnæus). Scaup Duck.

A common winter resident on the Sound, most abundant in November and March. Rare inland.

Earliest record. New Haven, Sept. 5, I886.

Latest record. New Haven, May 23, I902.

Inland records. Portland, Oct. I I, I888, a young male shot in Connecticut River by J. L. Goff (in coll. of J. H. S.) ; Portland, Dec. I4, I888, a female shot by Goff; Litchfield, Nov. 3, I905, one shot by H. Sanford (E. S. W.).

Unusual date. July $2 \mathrm{I}$, I882, one "pensioner" taken at Stony Creek by L. C. S.

\section{Marila affinis (Eyton). Lesser Scaup Duck.}

A tolerably common winter resident on the Sound, associating with $M$. marila, and most frequently taken in November and March. Less common inland.

Earliest record. New Haven, Oct. 20, 1902.

Latest record. Unusual date. July I4, I904, Quinnipiac Marshes, New Haven, a non-breeding adult male in worn plumage taken by L. B. B. New Haven, March 26, I895.

Inland records. East Hartford, April 26, I889, Oct. 8, I888 (W. E. T.) ; Middletown, Little River Marshes, one seen Oct. 23, I890, by W. E. T. and S. R., a female seen there also by J. H. S., June 10, I905, and a male, June I7, I905; Portland, Job's Pond, one shot July 9, I895 (in coll. of J. H. S.) ; Litchfield, Oct.

${ }^{1}$ Merriam, Birds of Conn., p. 126.

$2 \mathrm{Job}$, The Sport of Bird Study, p. 292. 
I9, I907, one shot (E. S. W.) ; one killed in the vicinity of East Windsor Hill by Dr. Wm. Wood (no date given). ${ }^{1}$

Marila collaris (Donovan). Ring-necked Duck.

A rare accidental winter visitor.

Connecticut records. Merriam ${ }^{1}$ records that Linsley took it at Stratford, and also that "G. B. Grinnell has secured several specimens in the vicinity of Milford"; April Io, I883, East Hartford, adult male shot (W. E. T.) ; Dec. I9, I885, New Haven, adult male secured by C. R. Hooker (formerly in coll. of L. C. S.) ; Oct. 26, 1887, Little River Marshes, Middletown, female shot by Dr. A. K. Fisher in company with J. H. S. (in coll. of J. H. S.) ; Oct. 3, r889, East Hartford, female shot (W. E. T.) ; April 9, 1895, Quinnipiac Marshes, New Haven, adult male taken by R. G. Van Name (in coll. of H. W. F.) ; Jan. 7, I898, Lake Saltonstall, young male taken by A. J. G. (in coll. of L. B. B.).

Clangula clangula americana Bonaparte. Golden-eye.

A tolerably common winter resident, especially along the coast, from December to March.

Earliest record. New Haven, Nov. I9, I904, Nov. I7, 1905 (E. S. W.) ; Portland, Oct. 29, I898; Litchfield, Oct. 30, 1905 (E. S. W.).

Latest record. New Haven, March 30, 1882, April 12, 1907 (A. A. S.) ; Portland, April 20, 1888.

Clangula islandica (Gmelin). Barrow's Golden-eye.

The only records for this state are: (I) that of A. J. G., who is well acquainted with the American Golden-eye, and who is positive that he took two males of this species at Lake Saltonstall, East Haven, Dec. 25, I883 (unfortunately these birds were not preserved); (2), a typical male adult specimen in the collection of J. H. S., which was purchased by him in the flesh, Nov. 14, 1867, from a man who said it was killed in the Sound, and whose statement there seems to be no reason for doubting. ${ }^{2}$

Charitonetta albeola (Linnæus). Buffle-head.

Formerly an abundant winter resident on the Sound and tidal

1 Merriam, Birds of Conn., p. 125.

2 Merriam, Birds of Conn., p. 126. 
creeks from December to February; also formerly common inland, especially during March. Now not more than tolerably common.

Earliest record. New Haven, Nov. 26, I884, Nov. 2, 1888 (L. B. W.) ; Portland, Oct. 25, I890; Bantam Lake, Litchfield, Oct. 23, I905 (E. S. W.) ; H. Sanford reports them on same date from same locality. ${ }^{1}$

Latest record. New Haven, Feb. I3, I894, April I0, I882 (A. H. Baldwin) ; Portland, April 26, I887.

Unusual record. July I4, I858, Lyme, female taken by R. Champion reported in MS. Journal of Jno. C. Comstock (J. H. S.).

\section{Harelda hyemalis (Linnæus). Old-squaw.}

An abundant winter resident on the Sound from November to April. Less common, if not rather rare, inland.

Earliest record. New Haven, Oct. 24, I895.

Latest record. New Haven, May 21, I888.

Inland records. Portland, Nov. 6, I888, Oct. 15, 1890, March 23, 1894, Oct. 18, I897, Oct. I4, I905; Litchfield, Oct. 19, 1907, one taken (E. S. W.).

' Summer records. June 17, 1896, an adult male in nuptial dress, prevented from going north by an old fracture of the wing, taken at New Haven by A. R. Andrews (in coll. of L. B. B.); Woodmont, Aug. 2-4, 1906, three seen (A. A. S.).

Breeding record. A pair with young was seen near Little Gull Island at the eastern end of the Sound in the summer of I886 by L. C. S. Mr. Grinnell in Merriam's Birds of Connecticut $^{2}$ notes that they occasionally breed here, though probably these are "pensioners."

Histrionicus histrionicus (Linnæus.) Harlequin Duck.

The only record for this state appears in Job, The Sport of Bird Study: "Mr. Williams examined a male (Histrionicus histrionicus) in full plumage shot by Matthew Parsons on Old Park Lake, Winsted, in October, seven or eight years ago"1 (I900 or I90I).

Camptorhynchus labradorius (Gmelin). Labrador Duck.

1 Job, The Sport of Bird Study, p. 292.

- Merriam, Birds of Conn., p. 127. 
The only references to this species appear in a paragraph in Merriam: "A very rare winter visitor. Linsley took it at Stratford, Conn. Pennant, in his Arctic Zoölogy, says that this species was 'sent from Connecticut to Mrs. Blackburn in England.' Arctic Zoölogy, vol. ii, p. 559, I785." 1

Somateria dresseri Sharpe. Eider.

Connecticut records. Linsley states that one or two Eider Ducks were killed at Stratford by Mr. Lucius Curtis. ${ }^{1}$ Grinnell informed Merriam that he had seen a specimen killed on the Sound near Milford, May 29, 1877, and that two, probably of this species, were shot there in the fall of $1874 .{ }^{1}$ Branford, Dec. 2, 1879, two shot, one in coll. of Dr. Fred. Sumner Smith of Chester (J. H. S.).

Mr. Alanson Ganung shot a young male, Dec. 20, 1909, off West Haven. It is now in the collection of L. B. B. This is the only recent record for this state.

Somateria spectabilis (Linnæus). King Eider.

A rare winter straggler in the Sound.

Connecticut records. Nov. 4, I883, an adult female taken near Milford by E. L. Munson ${ }^{2}$ (now in coll. of L. B. B.) ; Nov. I7, I886, one shot at Portland (in coll. of J. H. S.) ; Oct. 22, I890, a female found in the bag of some sportsmen at Stony Creek by A. E. V. (now in Peabody Museum) ; Nov. II, I893, one received by J. H. S. from Mr. Henry Noyes of Lyme; Nov., I900, a female taken near New Haven (in coll. of L. C. S.) ; winter, I902-3, a female taken in New Haven Harbor by A. Ganung; Nov. I4, I904, an adult male positively identified at Branford by L. C. S.; Oct. 26, male, Nov. 14, 1907, female, taken at Stratford (in coll. of L. B. B.); Nov. 2, 1908, two young shot at Stratford; Nov. 4, I908, a young male shot at New Haven by W. Ganung (in coll. of L. B. B.). Linsley also records obtaining two specimens at Stratford. C. L. Rawson states that a stuffed specimen is in Noank, shot off Groton Long Point in the winter of $1884^{3}$

Oidemia americana Swainson. Scoter.

1 Merriam, Birds of Conn., p. 127.

20 . and $O$., xii, 9, p. 156 .

3 . and $0 ., \mathrm{x}, 5, \mathrm{p} .74$. 
A rare fall migrant on the Sound; very rare along the inland waterways.

Coast records. Linsley records it from Stratford, and Merriam $^{1}$ calls it a "tolerably common winter resident," having seen it as early as Oct. 4, 1876. Oct., 1879, New Haven Harbor, one female collected by Dr. G. Woolsey (in Peabody Museum); April 23, 1889, Stony Creek, one seen (J. H. S.); Oct., I900, Branford, male taken by L. C. S. (in coll. of L. B. B.) ; Oct. 22, 1902, Branford, male taken by L. C. S.; Oct. 24, 1906, Stony Creek, young bird shot by A. H. V. (in coll. of L. B. B.) ; Oct. 4, 1909, West Haven, two males taken by A. Ganung (in coll. of L. B. B.).

Inland records. Oct. 9, 1888, Portland, seventeen of a flock of thirty shot by J. L. Goff (seven in coll. of J. H. S.) ; Oct. 2I, I890, Portland, flock of twenty-five seen (five in coll. of J. H. S.); Oct. 2, 1893, Portland, one seen by W. E. T.; Oct. 16, 1899, Middletown, two shot (in coll. of J. H. S.) ; Oct. 19, 1900, Portland, two shot.

Spring record. April 23, 1889, Stony Creek, one seen by J. H. S.

Oidemia deglandi Bonaparte. White-winged Scoter.

A common winter resident on the Sound, especially abundant in October and November, March and April. Not usually common inland.

Earliest record. New Haven, Oct. 13, 1883; Portland, Oct. 4, 1895 .

Latest record. New Haven, May 21, I888; Sachem's Head, June 8,1892 (J. H. S.).

Inland records. Oct. 19, 1881, Eastford, female shot (in coll. of C. M. Jones) ;2 Oct. 4, I895, Portland, about seventy-five seen in Connecticut River by S. R.; Oct. 12, 1895, Portland, adult male shot in Connecticut River (in coll. of J. H. S.) ; Oct. 16, I900, Portland, one killed by C. E. Lincoln; Oct. 20, 30, Nov. 3, 6, 1905, Oct. II, 28, 1907, common at Bantam Lake, Litchfield (E. S. W.).

Unusual record. Aug. 30, 1906, Pine Orchard (A. A. S.).

1 Merriam, Birds of Conn., p. 127.

$2 O$. and $O$., viii, 4, p. 32 . 
Oidemia perspicillata (Linnæus). Surf Scoter.

A common winter resident on the Sound, though not as common as $O$. deglandi, except in November. Rare inland.

Earliest record. New Haven, Oct. I3, I893.

Latest record. New Haven, April 19, I904; Stony Creek, April 23, I889 (J. H. S.).

Inland record. Oct. I5, I890, female shot at Portland by J. L. Goff (in coll. of J. H. S.).

Merriam $^{1}$ records one on the Sound as late as June $29,1877$.

Erismatura jamaicensis (Gmelin). Ruddy Duck.

Formerly a fairly common fall migrant on the Sound and larger lakes; now rare. Very rare in the spring.

Earliest record. New Haven, Oct. 24, I885; Oct. I4, I908 (P. B. Haines).

Latest record. New Haven, Nov. I, I882; Portland, Nov. I2, 1889; Litchfield, Dec. I, 1906 (E. S. W.).

Spring records. March 19, I889, East Hartford, five seen (W. E. T.) ; June 5, I893, Portland, three of a flock of five killed in Connecticut River (in coll. of J. H. S.).

Recent records. Since 1896 we have the following records only: Oct. 25, 1904, North Haven, a young female taken by Mrs. L. A. Farnham (in coll. of L. B. B.) ; E. S. W. reported them common on Bantam Lake, Litchfield, from Oct. 9 to Nov. I I, I905, also Nov. 24, I906, and Oct. II-28, I907; E. S. W. shot one, Dec. I, I906; Oct. I4, I908, a young male shot at North Haven by P. B. Haines (in coll. of L. B. B.) ; April I3, I906, Lake Saltonstall (A. A. S.) ; Oct. 5, 1907, Lake Burton (A. A. S.).

Subfamily Anserinde. Geese.

Chen hyperboreus nivalis (J. R. Forster). Greater Snow Goose.

An extremely rare winter visitor.

Connecticut records. Linsley records seven specimens of Snow Geese from Stratford; Merriam² reports a specimen in the possession of W. W. C., which had been killed near Saybrook in 
the fall of 1875 ; E. H. Austin informs us that three Snow Geese, undoubtedly of this species, spent the winter of $1868-9$ at Stratford; Nov. 20, I884, Portland, one adult male taken (in coll. of J. H. S.) ; Feb. 3, I893, L. H. Porter purchased two adults and two young in Fulton Market, New York City, where they had been sent a few days before from Stratford.

On the death of Dr. W. H. Hotchkiss of New Haven in 1907 , there was found among his effects the head of an adult male of this species, mounted. Dr. H. had previously informed L. B. B. that all of his collection had been taken in Connecticut about I878, so that this Snow Goose was in all probability killed in this state.

Branta canadensis canadensis (Linnæus). Canada Goose.

A common late fall and early spring migrant. Winters rarely.

Fall migration. Average, Oct. I5-Dec. I5. Earliest record. New Haven, Sept. I I, I883; Portland, Oct. I3, I886. Latest record. New Haven, Dec. 28, 1909 (Merrill); Portland, Dec. I 5, I89I.

Spring migration. Average, March I5-April 25. Earliest record. New Haven, March 20, I888; Portland, Feb. I7, I89I. Latest record. New Haven, April 25, I889 (L. B. W.), April 25, I909 (J. Lamb) ; Portland, May 30, I885.

Winter records. Merriam records ${ }^{1}$ that Grinnell told him that over two hundred remained about the mouth of the Housatonic River during the winter of 1876-7. In January, I904, a New Haven daily paper reported that a flock was wintering along the shore of the Sound east of Stonington. W. W. Coe ${ }^{2}$ saw one shot in the Middlefield reservoir, Jan. 4, I883. Three were shot from a flock of six at Clinton, Dec. 28, 1909, by C. A. Merrell (one in coll. of L. B. B.).

Branta canadensis hutchinsi (Richardson). Hutchins' Goose. Very rare.

Linsley records it from Stratford. G. B. Grinnell ${ }^{1}$ says it is recognized by the gunners about Milford (1877). E. H. Austin informs us that this species used to occur in small numbers at Stratford, and that he remembers seeing three, May 23, in the

1 Merriam, Birds of Conn., p. 122.

O. and O., viii, 3, p. 24 . 
sixties, in the possession of a gunner at Milford Point. He also reports one shot in South Kent a few years ago (about I900).

Branta bernicla glaucogastra (Brehm). Brant.

A rare straggler on the Sound in the fall and winter.

Linsley recorded the Brant as "common" in Stratford in the winter. Merriam ${ }^{1}$ gives the following records: spring, I877, Stratford Light, two killed (Grinnell) ; April I4, I876, mouth of East Haven River, three seen (Osborne); spring, 1876, Connecticut River above Hartford, one shot (Dr. Wood).

The following recent records appear: 1893-4-5, a large number wintered off Stamford (Porter); Dec. 21, I895, Stony Creek, a male taken by E. M. Cooper (in coll. of L. B. B.) ; Feb. 2r, I903, Stratford, two males and one female shot by G. Greenway (in coll. of L. C. S. and L. B. B.).

\section{Subfamily Cygnine. Swans.}

Olor columbianus (Ord). Whistling Swan.

The only records for Connecticut are as follows: Linsley mentions four specimens, two of which were killed, at Stratford; Merriam $^{2}$ records that two Swans were seen in Branford Harbor during a severe gale about the middle of March, 1876 (Beers), and several were seen at the same time near Milford (Grinnell); a young bird was shot off Grass Island, Guilford Harbor, by Mr. Reuben Hill, Nov. 2 or 3, 1893, and mounted by Capt. Brooks ${ }^{3}$ (now in the possession of Mr. Norton of Guilford); an adult taken in Fairfield is in the Linsley collection of the Bpt. Sci. Soc.

- Order HERODIONES. Herons, Storks, Ibises, etc.

Suborder IBIDES. Spoonbills and Ibises.

Family IBIDIDE. Ibises.

Guara alba (Linnæus). White Ibis.

The only record for New England is one reported by Merriam ${ }^{4}$ as seen by G. B. Grinnell, who wrote: "Late in the afternoon of May 23 (1875), I observed near Milford, Conn., a specimen of Ibis alba. I recognized the bird as it flew over me, and following it to a small pond, where it went down, discovered it perched upon

1 Merriam, Birds of Conn., p. 121.

2 Merriam, Birds of Conn., p. 120.

3 Reported by L. B. B., $A u k$, xi, 1, p. 74.

- Merriam, Birds of Conn., p. I10. 
a tree over the water. I carefully examined it with a good glass, at a distance of about one hundred and fifty yards, and by this means was enabled to note every detail of form and color. It was in full plumage, the white being pure, and the naked skin about the head bright red. After watching it for a few moments I tried to approach it, but before I came within gunshot it flew, uttering a hoarse cackle as it went off."

\section{Plegadis autumnalis (Linnæus). Glossy Ibis.}

Linsley obtained five specimens at Stratford. ${ }^{1}$

The only other record is that of Dr. J. Barratt ${ }^{2}$ of Middletown, who wrote in the Middletown Sentinel and Witness for May 2I, I850, that "One of these rare birds (Ibis falcinella) was shot in Middletown on the banks of the Connecticut, May 9th, time of high flood. It has been carefully preserved and is now in the cabinet of Dr. J. Barratt." He adds, "The Ibis falcinella is very rarely seen in the United States. This is the first that has come to our notice on the Connecticut, and has not been known in this country many years." Since this article appeared, the specimen has been presented to the Wesleyan University Museum, Middletown, and is in good condition.

- On page 92 in the copy of Nuttall's Manual (Water Birds) owned by Dr. Barratt, is the following marginal note in his handwriting: "My specimen, 28 inches, May, 1850. J. Barratt." (J. H. S.).

Suborder HERODII. Herons, Egrets, Bitterns, etc.

Family ARDEID瓜. Herons, Bitterns, etc.

Subfamily Botaurinæ. Bitterns.

Botaurus lentiginosus (Montagu). Bittern.

A common fall and less common spring migrant; rare summer resident. Most common during September and October, and April.

Fall migration. Earliest record. New Haven, Aug. 27, 1895; Portland, Sept. I4, I892. Latest record. New Haven, Nov. 2, 1903; Portland, Oct. 24, 1890.

'Merriam, Birds of Conn., p. Iro.

2 This specimen is also recorded in Merriam, p. Iro, and by J. H. S. in the $A u k$, iv, 3, pp. 253-4. 
Spring migration. Earliest record. New Haven, April 20, I887; Portland, April 8, 1887; Columbia; March 26, I894 (W. E. T.). Latest record. New Haven, May 4, 1898; Portland, May 2I, 1907.

Summer records. June 9, 1892, Portland (J. H. S.) ; June 24, 1893, June 21, 1894, Quinnipiac Marshes, North Haven (A. H. V. and L. B. B.) ; June 20, 1904, Salisbury (J. H. S. and L. B. B.) ; May 30, June II, I5, I89I, June 30, 1905 (E. S. W.), July 3, 1895, Litchfield (L. B. W.) ; July 23, I910, Portland (J. H. S.).

Winter record. Dec. 29, 1904, Stamford, a male in perfect condition taken (in coll. of Hoyt).

Nesting records. June, Portland, eggs taken (J. H. S.) ; June 27, 1907, Litchfield, four young in nest (E. S. W.).

\section{Ixobrychus exilis (Gmelin). Least Bittern.}

A rather rare summer resident of the marshes along the coast, occasional inland. Formerly common.

Earliest record. May 29, 1875, Portland.

Latest record. Sept. 22, 1902, New Haven.

Nest. Usually a mere hollow of rushes fastened to the flags of a grass-grown marsh.

Eggs. 4-5; middle of June.

Nesting dates. Earliest record. June 8, I898, five eggs (Hill). Latest record. June 27, I876, one egg (Nichols).

Merriam $^{1}$ notes this species as a pretty regular summer resident, having been particularly abundant throughout the state during the season of 1875 . At that same time W. W. C. informed Merriam that they bred regularly in the vicinity of Portland. Of recent years the Least Bittern has become relatively scarce.

Recent records: May, about 1896 , Winchester, pair seen (Williams) ;2 May, 1904, New Haven (A. A. S.) ; June 23, I904, Stratford, a breeding pair taken by E. Perry, Jr.; June I8, I907, Portland (J. H. S.) ; June 19, 1909, Morris Cove, New Haven, nest with four eggs (A. A. S.) ; Sept. 13, 1909, Goodspeed's Landing, bird taken (C. R. H.) ; June 15, I910, New Haven, deserted nest with one egg (H. K. J.) ; July 23, I9IO, Portland (J. H. S.).

1 Merriam, Birds of Conn., p. II3.

Job, The Sport of Bird Study, p. 293. 
Subfamily Ardeinse. Herons and Egrets.

Ardea herodias herodias Linnæus. Great Blue Heron.

A tolerably common spring and fall migrant. Very rare summer resident.

Spring migration. Average, April I-20. Earliest record. New Haven, March 22, 1902; Portland, April 3, 1896. Latest record. New Haven, April 29, 1884, and 1890, May 16, 1907 (A. A. S.); Portland, May II, I875.

Fall migation. Average, Aug. 20-Oct. 20. Earliest record. New Haven, July I4, 1893; Portland, Aug. 2, I880. Latest record. New Haven, Nov. 16, I904; Portland, Nov. 25, 1892 ; coast, Nov. 26, 1875 (Merriam). ${ }^{1}$

Summer records. June 2, 1877, New Haven (W. P. Nichols) ; ${ }^{1}$ May 15, 1897, May 21, I898, New Haven (L. B. B.); June 7, 1897, May 13, I8, June 3, 1905, Litchfield (E. S. W.). E. S. W. says this species is often seen in the summer at Bantam Lake, Litchfield. Nest found in Winchester about 1900 by Williams (Job). ${ }^{2}$

Herodias egretta (Gmelin). Egret.

- An irregular transient visitor in late summer.

Connecticut records. Prior to 1877 , a specimen was shot near Middletown (in Museum of Wesleyan University) $; 3$ Grinnell reported seeing it on the marshes near Milford in September; ${ }^{3}$ Dr. Wood reported one near East Windsor Hill "several years ago" (i. e., before 1877$) ;^{3}$ a pair, seen at Lake Saltonstall, July, 1876, and later not less than seven (F. S. Smith) ; $;^{3}$ Aug. 2, I878, and Aug. II, I882, specimens shot by J. R. Chalker near Saybrook (latter in coll. of J. H. S.) ; April I, I883, Stamford, adult in full nuptial plumage taken (Schaler); Aug. 14, 1883, Hartford (W. E. T.) ; ${ }^{5}$ 1883, East Haven (L. T. Hotchkiss, in Peabody Museum) ; July 29, I897, July 30, I898, Aug. 8, 1898, Stamford, young taken (Schaler); Aug. 19, 1897, Clinton, one shot; Aug., 1897, Quinnipiac Marshes, North Haven, one seen (Robert-

1 Merriam, Birds of Conn., p. Iro.

2 Job, The Sport of Bird Study, p. 293.

Merriam, Birds of Conn., p. III.

4. and $O$., vii, 24, p. 189 ; viii, $I$, p. 4 .

- $A u k$, iv, 1, p. 78. 
son); Aug., I899, flock of a hundred seen near East Haven marshes, a number ropsting nightly at Branford (Nichols); July 28, I899, Kent, one taken by Hall (in coll. of H. K. J.) ;1 July 25 , I906, Canaan, one shot (in coll. of Pease) ; Aug., I9I I, near Greenwich, one seen (P. G. Howes) ;2 Aug. 15-30, I9I I, West Haven, two seen (J. Hitchcock).

Egretta candidissima candidissima (Gmelin). Snowy Egret.

Merriam ${ }^{3}$ characterizes this species as "a rare accidental visitor from the South." He further states that Linsley saw it at Stratford and that Dr. Crary has taken it at Hartford (prior to 1877). C. L. R. of Norwich writes in O. and O.:4 "In early October I have seen eleven Snowy Herons at the point (Groton Long Point) at once, at another time nine, and smaller groups in other seasons." Mr. Jno. C. Comstock, in his journal kept at Lyme, records five specimens seen July 28, 1853, and thirteen Aug. I6, I853 (J. H. S.).

Florida cærulea (Linnæus). Little Blue Heron.

A rare straggler from the South.

Merriam ${ }^{3}$ gives the following records: Linsley took it at Stratford; April, 1877, one seen in Lake Whitney (doubtful record); May (I876?), Suffield, one shot (doubtful record).

Other records: July 28, I875, Wethersfield, two seen, a young male killed by Mr. Ransom T. Hewitt (in coll. of W. W. C., and recorded in part by Merriam); Aug. I2, 188I, Saybrook, a specimen in immature plumage obtained from a flock of about six (J. N. C.) ; summer, I895, one taken near New Haven and mounted by a local taxidermist; Aug. 4, 1897, Niantic, one taken (P. J. McCook); July '2I - Aug. 5, I899, Lyme, seven seen, two taken (A. W. Brockway) ;6 Sept. 15, 1899, Stratford, one young in a flock of three taken (in coll. of L. C. S.) ; April 27, I900, Portland, female in adult plumage shot by Hurlburt (in coll. of J. H. S.) ; Aug. 2, I90I, Guilford, young shot (in coll. of L. B.

1 H. K. Job, The Sport of Bird Study, p. 294.

2 Oölogist, xxviii, 9, p. 152.

3 Merriam, Birds of Conn., p. III.

- $O$. and $O ., \mathrm{xvi}, 4$, p. 59 .

- $O$. and $O ., \mathrm{vi}, 7, \mathrm{p}$. $5 \mathrm{I}$.

$A u k$, xvi, 4, p. 152 . 
B.) ; July 22-Aug. 18, and Sept. 7, 1904, Niantic, one to ten seen (McCook). ${ }^{1}$

Butorides virescens virescens (Linnæus). Green Heron.

A common summer resident throughout the state, arriving early in May, and the majority leaving early in September.

Earliest record. New Haven, April 27, I886; Portland, April 24, 1902.

Latest record. New Haven, Oct. 2, 1902, Oct. 15, 1898 (E. S. W.) ; Portland, Oct. I, I894; Guilford, Oct. 22, I909 (H. E. Watrous).

Nest. In a cedar, hemlock, or white birch, as a rule, and at a height of from 8 to 30 feet from the ground. Frequently in a small colony, but often alone.

Eggs. 4 or 5, usually 5 ; the last of May.

Nesting dates. Earliest record. May II, I906, five eggs (E. S. W.). Latest record. July 8, 1882, five young (L. B. B.).

Nycticorax nycticorax nævius (Boddaert). Black-crowned Night Heron.

A summer resident from May to October.

Earliest record. New Haven, April 3, I888; Portland, April 28, 1905 .

Latest record. New Haven, Nov. 17, 1900; Portland, Nov. I2, 1902.

Nest. Usually high in the top of a pine or hemlock and in colonies.

Eggs. 3-5; the latter part of May.

Nesting dates. Earliest record. May 4, 1902, five eggs (Beers). Latest record. June 20, 1886, two eggs. (Eames).

Colonies. Rocky Hill, 1872, hundreds reported breeding in a heronry;2 Lake Whitney, prior to I88I, a colony in Heron Swamp - again occupied by many pairs in 1904 and later (Bennett); near Norwalk, I903, twenty to twenty-five pairs breeding in a heronry (Canfield and Watrous), numbers greatly increased in 1904 (Perry); Wood ${ }^{3}$ reported a rookery where

1 Auk, xxii, 1, p. 77 .

2 Merriam, Birds of Conn., p. II 2.

- Samuels, Birds of New England, p. 4 Io. 
"thousands" bred, fourteen miles from East Windsor, now practically abandoned (J. H. S.).

Unusual record. Feb. 9, I0, and II, I880, a specimen flushed in the open spaces of water on the Thames River, Norwich, by C. L. R. ${ }^{1}$

Albino. Summer of I894, Stamford, young bird, creamy white with markings of pale russet and écru-drab (W. H. Hoyt, in coll. of L. B. B.).

Order PALUDICOLÆ. Cranes, Rails, etc.

Suborder RALLI. Rails, Gallinules, Coots, etc.

Family RALLIDÆ. Rails, Gallinules, and Coots.

Subfamily RaLline. Rails.

Rallus elegans Audubon. King Rail.

Rare.

Linsley found it breeding at Stratford; Merriam ${ }^{2}$ reports a specimen in the possession of J. N. C., taken at Saybrook, Jan. I4, 1876; Sept. 17, 1879, Portland, female killed (in coll. of J. H. S.) ; c. I882-5, specimens shot at Glastonbury, Wethersfield, and East Haddam (reported by Sperry to L. B. B.) ; Sept. 23, I892, Middletown (W.E.T.) ; Sept. I, I895, Little River Marshes, Middletown, male taken (in coll. of C. H. N.) ; Sept. 5, I90I, Quinnipiac Marshes, North Haven, young male taken (G. V. Smith, in coll. of L. B. B.) ; Sept. 26, 1905, same location, young female (Sperry, in coll. of L. B. B.) ; April 22, 24, I9IO, Leete's Island, two females trapped (in coll. of L. C. S.) ; J. N. C. informed L. B. B. that he had taken one set of eggs many years ago.

Rallus crepitans crepitans Gmelin. Clapper Rail.

A rather rare summer resident of the salt-water marshes of the western part of the state; occasionally wintering.

Earliest record. East Haven, May 24, I879 (Woolsey).

Latest record. Fairfield, Nov. 13, I891 (Eames).

Winter record. Feb. 9, I900, Stamford (Hoyt).

Nest. A nest of rushes in the marshes.

10. and $0 ., \mathrm{v}, 10, \mathrm{p} .78$.

2 Merriam, Birds of Conn., p. 115 . 
Eggs. 8-14; in June.

Nesting dates. Earliest record. June 17, 1893, eight eggs (Schaler). Latest record. June 25, I891, twelve eggs (Lucas).

Recent records. Stamford, 1874, fourteen eggs, Sept., 1893, four taken, Feb. 9, I900, male taken (Hoyt), June 17, 1893, female and eight eggs (Schaler), Sept. 27, I893, female taken (Porter) ; Fairfield, Nov. 13, I891, female taken (Eames) ; Stratford, June 25, I891, twelve eggs taken (W. H. Lucas), ${ }^{1}$ Sept., I893, one taken (in coll. of L. C. S.) ; Milford, Dec. 20, I892 [?] (A. H. V.), May 26, 1900, male taken (Beers); West Haven, May 30, 1904, female taken (L. B. B.) ; New Haven, r882, twelve eggs (E. H. Barbour), Sept. II, I886, female taken (C. H. Webb) ; East Haven, May 24, I879, male taken (Woolsey); Guilford, Sept. 10, 1884, female taken (L. B. B.) ; Saybrook, one record (J. N. C.).

Rallus virginianus Linnæus. Virginia Rail.

A rather rare summer resident from May to October, and a tolerably common fall migrant.

Earliest record. New Haven, May 19, I904, April 20, 1906 (E. S. W.) ; Portland, April 22, I910.

Latest record. New Haven, Oct. 29, 1904; Portland, Oct. 20, I890.

Nest. In rushes in fresh-water marsh.

Eggs. 7-ro; early in June.

Nesting dates. Earliest record. May 18, 1910, eleven eggs (C. G. H.). Latest record. July 3, I892, ten eggs (J. H. S.).

Porzana carolina (Linnæus). Sora.

An abundant fall migrant in September and October, frequenting the wild rice and cat-tail rushes in the tidal marshes, as well as the marshes along the inland waterways. Rare in the spring.

Fall migration. Average, Sept. I - Oct. 25. Earliest record. New Haven, Aug. 23, 1902; Portland, Aug. 17, 1897. Latest record. New Haven, Nov. I, 1895; Portland, Nov. 5,.1894.

Spring records. May 28, I898, New Haven, a female taken (Andrews, in coll. of L. B. B.) ; June 3, 1905, Litchfield (E. S.

1 Recorded in Averill's Birds of Bridgeport as Gallinula galeata. 
W.) ; May I-5, I908, May I7, I909, May I6, I910, Portland (J. H. S.).

Summer record. Aug. 12, I900, Westville (G. V. Smith).

Winter record. Dec. 29, I88I, Hartford, a male shot (H. T. G.). ${ }^{1}$

Breeding records. I882, Norwich, three sets of nine eggs each (C. L. R.) ;2 May 30, 1909, Talmage Hill (New Canaan), eleven eggs (P. G. Howes). ${ }^{3}$ Nested at Portland in the early sixties, and eggs taken at that time have ever since been in the coll. of J. H. S. No recent record.

Albino. Quinnipiac Marshes, Sept. 30, I901, young female taken, colored yellowish tawny olive with markings of broccolibrown (C. R. Hooker, in coll. of L. B. B.).

Coturnicops noveboracensis (Gmelin). Yellow Rail.

A fall migrant in October to our marshes; probably not uncommon, but seldom taken owing to its secretive habits.

Merriam ${ }^{4}$ records that they breed about Middletown (W. W. C.), and that several have been taken near Milford (Grinnell) and Stratford (Linsley).

Earliest record. Little River Marshes, Middletown, Sept. 8, I894 (in coll. of J. H. S.).

Latest record. Milford, Nov. Io, 1876 (Grinnell).4

Spring record. March 24, I888, Gaylordsville, a male taken by E. H. Austin (in coll. of Bpt. Sci. Soc.).

Fall records since 1894. Middletown, Sept. 8 (1894)-Oct. 25 (1894), five taken (Gould, Strong, Tryon, in coll. of J. H. S.) ; Quinnipiac Marshes, Sept. I5 (I908)-Oct. I5 (I894), twelve taken (Andrews, A. Ganung, P. Stetson, Whitney, H. W. F., L. C. S., L. B. B., in coll. of H. W. F., L. C. S., and L. B. B.).

Breeding record. The only breeding record is that of W. W. C., ${ }^{4}$ who informed Merriam that they bred about Middletown in I874 and 1875. A questionable record - probably a misunderstanding ( $J$. H. S.).

Creciscus jamaicensis (Gmelin). Black Rail.

A rare summer resident.

10. and 0. , vii, 15, p. 119.

20 . and 0 ., vii, 22, p. 173 .

- Oölogist, xxviii, 5, p. 90.

1 Merriam, Birds of Conn., p. II8. 
Connecticut records. July 10, 1876 , Saybrook, female sitting on nest of ten eggs (four eggs in coll. of J. N. C.) ; June I3, I884, Saybrook, nine eggs taken (J. N. C.) ;2 July Ir, I893, Aug. I2, 1904, Quinnipiac Marshes, North Haven, flushed (?), but not obtained (L. B. B.) ; Sept. 14, 1904, Essex, young bird (Whitney, in coll. of L. C. S.).

\section{Crex crex (Linnæus). Corn Crake.}

The only record of this species in Connecticut is that of $\mathrm{J}$. N. C. of Saybrook, who obtained an adult male, Oct. 20, I887, in a swampy thicket at the head of a marsh some two miles from Long Island Sound. It is recorded and described in $O$. and $O$., xiii, 3 , pp. $45-6$.

\section{Subfamily Gallinuline. Gallinules.}

Ionornis martinicus (Linnæus). Purple Gallinule.

A very rare accidental visitor from the South.

Merriam $^{1}$ records a specimen taken near Middletown, about 1855, and now in the Wesleyan University Museum; Henry R. Smith of Stamford mounted a specimen taken there in 1877 , while Hoyt reports another from Stamford in the spring of 1884 ; a female was collected at Bridgeport, Jure 26, 1903, by J. H. Canfield (in coll. of Beers).

Gallinula galeata (Lichtenstein). Florida Gallinule.

A rather rare fall visitant, occasionally taken by sportsmen while shooting Rail.

Although Grinnell ${ }^{1}$ called it a rather common summer resident, the only summer record which we have is a specimen in the Peabody Museum, taken by E. L. Coe, in New Haven, in June, I899.

Coast records. Sept. 28, I889, Stratford, female taken (in Averill coll. of Bpt. Sci. Soc.) ; Sept. 20, 1903, Sept. 15, 1904, Essex (in coll. of L. C. S.) ; Sept. 30, 1902, New Haven (H. Whitney); Sept. 4, 1906, Essex (F. F. Brewster, in coll. of L. B. B.) ; Oct. 16, 1906, Stratford (L. C. S.) ; Sept. 15, 28, 1908, New Haven (P. Stetson); Sept. 25, I9I I, Stratford, two taken (H. W. B.). 
Inland records. Sept. 23, I892, young female, Sept. 21, 1894, young female, Oct. 15, I895, female, Sept. 3, 1903, male shot at Little River Marshes, Middletown (in coll. of J. H. S.) ; Sept., I907, Canaan, one shot by Stevens, who also saw one that had been shot there in Sept., I906 (H. K. J.) ; ${ }^{1}$ Sept., I895, one collected at Litchfield by H. Sanford (E. S. W.) ; Oct. 12, I908, Goodspeed's Landing, one shot (Brackett, in coll. of L. B. B.).

\section{Subfamily Fulicinæe. Coots.}

Fulica americana Gmelin. Coot.

A tolerably common fall migrant in September and October; much rarer than formerly. Seldom seen in spring.

Earliest record. New Haven, Sept. 21, I896; Portland, Sept. 19, I893.

Latest record. New Haven, Oct. 3, I888; Portland, Nov. I4, I892.

Spring records. May I, 1887, April 22, May 15, I888, Portland (J. H. S.) ; April 2-23, I9I0, West Haven (H. K. J.).

Summer record. July 19, 1906, Portland (J. H. S.).

Order LIMICOLAE. Shore Birds.

Family PHALAROPODID无. Phalaropes.

Phalaropus fulicarius (Linnæus). Red Phalarope.

An accidental visitor during migrations.

The first record is that noted by $\operatorname{Merriam}^{2}$ (1877): "W. W. Coe has a specimen in his cabinet killed at Portland in September." May 22, I881, Portland, one obtained by C. H. N.; Sept. 27, I886, Hartford, female shot by W. E. T. ;3 Oct. 21, I890, Portland, female shot by J. L. Goff (in coll. of J. H. S.) ; May 24, 1894, East Haven, a male in nuptial dress taken by L. B. B.; Nov. 24, 1895, Portland, male taken, Oct. 2, 1903, female shot (in coll. of J. H. S.) ; Sept. 25, I908, West Haven, a young female shot by P. B. H. (in coll. of L. B. B.).

Lobipes lobatus (Linnæus). Northern Phalarope.

An accidental visitor in the spring and fall. 
Connecticut records. Aug. 4, 1886, ${ }^{1}$ Sept. 12, I889, Quinnipiac Marshes, North Haven, males, taken by E. L. Munson; Aug. 24, 1893, West Haven, taken by A. H. V. (in coll. of Porter) ; May 20, I894, Bridgeport, male killed by flying against electric wires (in coll. of J. C. A. M.) ;2 May 21, 1894, Quinnipiac Marshes, four seen, two females taken (L. B. B.) ; May 22, 1894, East Haven, two males and a female secured (H. W. F.).

Steganopus tricolor Vieillot. Wilson's Phalarope.

The only record of this species in Connecticut is the specimen recorded by Linsley as killed in Bridgeport. It is a female in breeding plumage, and is now in the collection of the Bpt. Sci. Soc.

Family RECURVIROSTRID死. Avocets and Stilts.

Recurvirostra americana Gmelin. Avocet.

Merriam $^{3}$ notes the only specimen recorded from this state: 187r, between Saybrook and East Lyme, a specimen caught in an old seine strung out on the beach to dry, and kept alive for some time (J. G. Ely).

\section{Family SCOLOPACID无. Sandpipers, etc.}

Philohela minor (Gmelin). Woodcock.

A summer resident, though more common during migrations; occasionally wintering. Breeds in less numbers than formerly. Most common during March, and from Sept. 15 to Nov. 25.

Earliest record. New Haven, March 3, 1883; Portland, Feb. 28, 1878 .

Latest record. New Haven, Nov. 22, 1894, Nov. 26, 1906 (E. S. W.) ; Portland, Nov. 28, 1895.

Winter records. Dec. I8, I882, Dec. 31, I895, New Haven (L. B. B.) ; Feb., I884, New London County (C. L. R.) ${ }^{4}$; Jan. 26, I890, Bridgeport (W. H. Lucas); Jan. I, I903, East Haven (H. W. F.) ; Dec. 9, 1906, Dec. 28, 1907, New Haven (A. A. S.).

1O. and $O$., xii, 9, p. 156.

2 Auk, xii, I, p. 77; wrongly recorded as $P$. fulicarius (L. B. B.).

3 Merriam, Birds of Conn., p. 103.

1O. and $O$., ix, 2, p. 57 .

- $O$. and $O ., \mathrm{xv}, 2$, p. 3 . 
Nest. Eggs are laid on a bed of dry leaves or on moss, with no pretense of a nest.

Eggs. 4.

Nesting dates. Earliest record. March 24, 1886, egg ready for nest taken from bird (L. B. B.) ; March 29, 1898, four eggs (Hill). Latest record. June 3, 1875, Norwich, four eggs (C. L. R.). ${ }^{1}$

The strange habit of grasping its young between its claws and carrying it through the air in its flight has been noted both by J. H. S., May 30, 1874, and by L. B. B., April 27, 1894.

Albino. New Haven, Nov. 7, 1894, abdomen white, and rest of plumage very pale, taken by J. B. Robertson.

Gallinago delicata (Ord). Wilson's Snipe.

A tolerably common spring and fall migrant in April, October and November, but rapidly decreasing in numbers. Very rare summer or winter resident.

Spring migration. Average, March 25 to May 1o. Earliest record. New Haven, March.29, I898, March I9, I894. (H. W. F.) ; Portland, March I8, I874. Latest record. New Haven, May I3, I882; Portland, May I4, I874, May I3, I9o9.

Fall migration. Average, Sept. I to Oct. 25. Earliest record. New Haven, Sept. 18, 1895; Portland, Sept. I, 1892, 1893. Latest record. New Haven, Dec. I, 1882; Portland, Dec. 7, 1877.

Winter records. Feb. 4, 1872, Portland (W. W. C.) ; Jan. 22, I896, New Haven (L. B. B.).

Summer records. Aug. 5, I886, North Haven (E. L. Munson) ; Aug. I2, I889, East Hartford, one found under a telegraph wire (W. E. T.).

Breeding record. May 13,1874 , Portland, nest with three eggs found and fully identified, since parent bird was on nest (J. H. S. and W. W. C. $)^{2}$. Several birds of this species were in the meadow at the time and also on the following day, but we saw only the one nest (J. H. S.).

Macrorhamphus griseus griseus (Gmelin). Dowitcher.

Very rare; now merely an accidental fall migrant in July and August.

2 Merriam, Birds of Conn., p. 105. 
Connecticut records. Merriam" characterizes it as " not rare during the migrations." Linsley took it at Stratford. Aug. 2I, 1874, Saybrook, two shot by W. W. C., one in collection of J. H. S.; Aug. 20, I892, Grove Beach, Clinton, a young male, Aug. I5, I894, a young male and two young females (H. W. F.) ; July, I892, and I894, Stamford (Schaler) ; Aug. 27, I897, Guilford, a young female (L. B. B.) ; Capt. Jas. Holt of Lyme informed W. E. T. that he had seen eight (about I893).

Macrorhamphus griseus scolopaceus (Say). Long-billed Dowitcher.

The only record for Connecticut is that of an adult taken on the Quinnipiac Marshes, North Haven, Aug. 5, 1886, by Dr. E. L. Munson (in coll. of L. C. S.).

Micropalama himantopus (Bonaparte). Stilt Sandpiper.

A rare straggler in May, August, and September.

Connecticut records. June, 1874, three, Aug. 30, 1886, Quinnipiac Marshes, North Haven (in coll. of Dr. E. L. R. Thompson), incorrectly reported in Merriam ${ }^{2}$ and $O$. and $0 .^{3}$ as Curlew Sandpipers (corrected by L. C. S.) ; Sept. I6, r886, same locality, one young taken (E. L. Munson) ; Sept. I7, I886, near New Haven (in coll. of L. C. S.) ; Aug. 20, I892, Grove Beach, Clinton, adult female taken (H. W. F.) ; May 30, I894, West Haven, adult female taken (L. B. B.).

Tringa canutus Linnæus. Knot.

A rare straggler on the coast in the spring and fall. Formerly "common during migrations."

Connecticut records. Merriam records that W. W. C. has "found it about the Connecticut River near Middletown in summer" [probably a misunderstanding as to species (J. H. S.)]. Aug. 21, 1874, Saybrook (J. H. S.) ; Sept. 20, 1882, West Haven, one taken (A. H. Baldwin) ; Sept. 9, I885, same place, one young taken (Munson, in coll. of L. C. S.) ; Sept. 25, I903, same place, young male (A. Ganung, in coll. of L. B. B.) ; Jas. Holt of Lyme

1 Merriam, Birds of Conn., p. I05.

2 Merriam, Birds of Conn., p. 106.

30 . and 0. , xii, 9, p. 156.

4 Merriam, Birds of Conn., p. 107. 
says they were found in September (1893?) ; L. C. S. informs us that seven were shot in West Haven by Hotchkiss several years ago.

Arquatella maritima maritima (Brünnich). Purple Sandpiper.

A rare late fall migrant, frequenting the rocky islands off the coast, and an occasional winter resident.

Capt. Brooks wrote Merriam ${ }^{1}$ that "Purple Sandpipers come here [Faulkner's Island] in early fall and stay till spring."

Connecticut records. Nov., 1879, Stamford, two taken by Hezekiah Weed (Hoyt); April 22, I88I, Saybrook, female taken (in coll. of J. H. S.) ; c. I882, Saybrook, one secured (J. N. C.) ; Nov. IO, I883, Guilford, one secured from a small flock (L. B. B.) ; Nov. 28, 1885, Stony Creek (G. E. V., in Peabody Museum); Nov. I5, 1888, Stamford, one taken (Hoyt) ; Nov., I891, Stamford, two taken by Hecker (Hoyt) ; Jan. I, I893, New Haven, one shot (C. Webb, in coll. of Porter); March 31, I893, May, 1897, Dec. I8, I897, Branford (L. C. S.) ; Jan. I, 1894, New Haven (A. H. V.) ; Nov. 20, I895, Stony Creek, one shot (E. M. Cooper) ; winter, $1898-9$, a few seen frequently on the small rocky islands at the eastern end of the Sound (G. E. V.).

Pisobia maculata (Vieillot). Pectoral Sandpiper.

A common fall migrant; unknown in the spring.

Earliest record. New Haven, July 30, I890; Portland, Sept. 25,1890 .

Latest record. New Haven, Oct. 21, I895; Portland, Oct. 31, I89I.

The adults pass in August, Aug. I7 (I882) to Aug. 27 (I882, 1897). The young follow in September, Sept. 6 (I894) to Oct. 2 I ( 1895 ).

Summer record. July 26, I890, Quinnipiac Marshes, North Haven, flock of ten seen (Trowbridge).

A hybrid between $P$. maculata and $P$. fuscicollis was taken on the Quinnipiac Marshes, Aug. 4, I894, by L. B. B. It was with a few Spotted Sandpipers, and was remarkably tame. No Pectoral or White-rumped Sandpipers were seen that day. This 
bird was an adult male with rather undeveloped genitalia, its remarkably unworn plumage also indicating that it had not bred. In general coloring it resembles $P$. fuscicollis in breeding plumage, the rump more nearly approaching that of $P$. maculata. The upper tail coverts are white, the feathers, as a rule, broadly banded or striped with brown. The breast feathers are washed with brownish, as in $P$. maculata, and their dark centers are broader than in $P$. fuscicollis. In measurements this bird is exactly halfway between males of the two species, and practically identical with females of $P$. maculata: length, 8.25 in.; extent, I6.62 ; exposed culmen, 1.07; wing, 5.07; tail, 2.46; tarsus, I.12; middle toe with nail, I in. The sternum also is about the size of that of the female $P$. maculata, and intermediate between males of the two species.

Pisobia fuscicollis (Vieillot). White-rumped Sandpiper.

A tolerably common fall migrant on the coast in September and October. Rare inland.

Earliest record. New Haven, Aug. 24, 1895.

Latest record. New Haven, Oct. 19, I904; Lyme, Oct. 2I, 1893 (W. E. T.) ; Branford, Oct. 23, I905 (L. C. S.).

Adults pass during September, Aug. 24 (I895) to Sept. 30 (I886). The young follow in October, Sept. 30 (1894) to Oct. I9 (I904).

Inland records. Oct. 30, I891, Oct. 24, 1895, East Hartford (W. E. T., latter specimen in coll. of J. H. S.).

Unusual records. Nov. 4, I896, Quinnipiac Marshes, North Haven, a wounded bird taken (L. B. B.) ; May 19, I904, same place, one seen (L. B. B.).

Pisobia bairdi (Cones). Baird's Sandpiper.

A rare and probably accidental fall migrant.

Connecticut records. Oct. 28, I887, West Haven, a female shot, Oct. I9, I889, a male shot (L. B. W.) ;1 Nov. 3, I888, Stratford, female taken (C. K. A., Jr.) ;2 Sept. 29, I894, Bridgeport, two taken by H. H. Taylor (Eames); fall, I9or, Saybrook, several taken (J. N. C.) ; Sept. I4, I904, West Haven, young 
male taken by A. Ganung (in coll. of L. B. B.) ; Sept. 9, I9ro, Bridgeport, female taken (H. W. B.).

\section{Pisobia minutilla (Vieillot). Least Sandpiper.}

A common spring and fall migrant along the coast; not rare inland.

Spring migration. Earliest record. New Haven, May 8, I900, May 6, I905 (A. A. S.). Latest record. June 5, 1894.

Fall migration. Earliest record. New Haven, July 14, I904. Latest record. Sept. 22, 1883.

The old birds pass south about the middle of July, and the young birds follow during August and the first half of September.

Inland records. May 19, I883, Portland, one taken (in coll. of J. H. S.) ; Sept. 9, r892, Middletown, four killed (in coll. of J. H. S.) ; May 23, I893, East Hartford (W. E. T.) ; May I7, I895, Portland, three shot by C. H. N. (two in coll. of J. H. S.).

Pelidna alpina sakhalina (Vieillot). Red-backed Sandpiper.

A rare spring and tolerably common late fall migrant along the coast.

Fall migration. Earliest record. New Haven, Sept. 25, 1903. Latest record. New Haven, Oct. 29, 1895.

Spring record. May 19, 1904, Quinnipiac Marshes, North Haven (L. B. B.).

Almost all specimens of this Sandpiper taken in Connecticut are young birds.

A young female in the collection of L. B. B., shot by A. Ganung in West Haven, Sept. 29, 1904, is almost as small as a European Dunlin (Pelidna alpina alpina) : length, 8.44; culmen, I.42; wing, $4.5 \mathrm{I}$; tarsus, I.I2. It was very lean, as if it had traveled far without resting, whereas our Red-backed Sandpipers are usually very fat in the fall. It is only a trifle larger than an adult female Dunlin from England; but, as the chief character separating these races is the length of the bill, and as the bills of most sandpipers do not reach their full size until late in the first fall, it seems safer to consider this bird merely an unusually small Red-backed Sandpiper. 
Ereunetes pusillus (Linnæus). Semipalmated Sandpiper.

An abundant spring and fall migrant on the coast; not rare inland.

Spring migration. Earliest record. New Haven, May II, 1897. Latest record. New Haven, June I, r894.

Fall migration. Earliest record. New Haven, July 30, 1896. Latest record. Oct. 23, 1894 .

The adults go south in August, Aug. 2 (1894) to Aug. 27 (1895), and the young follow in August, September, and October, Aug. 9 (I882) to Oct. 23 (I894).

Inland records. Sept. 25, I890, Middletown, one killed ( $\mathrm{J}$. H. S.) ; Oct. 7, r891, Middletown, seen by W. E. T. and S. R.

A partially albinistic young female with the wings largely white, in the collection of L. B. B., was taken in West Haven, Oct. 2, 1903, by A. Ganung.

Breeding record. The only breeding record is that appearing in Merriam, ${ }^{1}$ of the four eggs found by Nichols in Branford, July 20, 1877; but an examination of the only one of these four eggs now extant (in the Brewer collection in the Museum of Comparative Zoölogy, Cambridge), by Mr. Outram Bangs and L. B. B., has proven this to be an unusually small egg of Actitis macularia. It does not resemble eggs of either the Semipalmated or the Least Sandpiper in shape, color, or markings, while in all these respects it is typical of Actitis macularia. We have therefore no breeding record of $E$. pusillus.

Ereunetes mauri Cabanis. Western Sandpiper.

Probably occurs regularly in the fall, but in so small numbers as to escape notice.

Connecticut records. Sept. 4, I889, Lyme, six seen and three shot by W. E. T. (in coll. of J. H. S.) ;2 Aug. 17, 1892, Clinton, young female taken (H. W. F.) ; Aug. 27, 1895, Quinnipiac Marshes, North Haven, young female shot (L. B. B.).

Calidris leucophæa (Pallas). Sanderling.

Formerly an abundant spring and fall migrant; now rare, and occurring regularly only in the fall. 
Fall migration. Earliest record. New Haven, Aug. 20, 1902. Latest record. Oct. 20, 1902.

Spring record. May 13, 1878, Saybrook, one male taken by H. W. F. (in coll. of Brewster).

Inland record. Sept. I2, I894, one male taken at East Hartford by W. E. T. (in coll. of J. H. S.).

Linsley took it at Stratford. Merriam ${ }^{1}$ says it "occurs during migrations, and is extremely abundant in fall."

\section{Limosa fedoa (Linnæus). Marbled Godwit.}

Connecticut records. Aug., 1842, Stratford, an adult female (?) (Linsley, in coll. of Bpt. Sci. Soc.) ; Aug. 26, 1909, West Haven, adult female shot by Wm. Ganung (in coll. of L. B. B.).

Limosa hæmastica (Linnæus). Hudsonian Godwit.

Connecticut records. Stratford (Linsley ${ }^{2}$ and E. H. Austin). ${ }^{3}$

On page 178 in the copy of Nuttall's Ornithology (Water Birds) owned by the late Dr. J. Barratt, of Middletown, Conn., is the following marginal note, in his handwriting, relating to this species: "A pair shot by Jenkins Oct. 25, I845 - these were bought by me and set up." (J. H. S.)

Oct. 30, I852, Lyme, taken by Jno. C. Comstock (MS. Journal of Jno. C. Comstock, J. H. S.) ; Oct. II, 1897, Little River Marshes, Middletown, one shot by L. E. King (in coll. of J. H. S.).

Totanus melanoleucus (Gmelin). Greater Yellow-legs.

A tolerably common spring and more common fall migrant, but becoming rarer at both seasons.

Spring migration. Earliest record. New Haven, April 2I, 1897; Portland, May 3, 1893. Latest record. New Haven, June 4, I900; Portland, June 5, 1882; Litchfield, June 9, 1905 (E. S. W.).

Fall migration. Earliest record. New Haven, Sept. 3, r886; Portland, Sept. 24, 1881. Latest record. New Haven, Nov. 3, 1906; Portland, Oct. 27, 1894.

Unusual records. March 25, I893, West Haven (L. C. S.) ; Nov. 22, 1895, West Haven, wounded bird (A. H. V.) ; July,

1 Merriam, Birds of Conn., p. 107.

$2 \mathrm{Am}$. Jour. of Sci. and Arts, [1] xliv, 2, p. 267.

Averill, Birds of Bridgeport, p. 8. 
I897, New Haven, ten taken (Trowbridge) ; Dec. II, I902, Portland (J. H. S.).

Totanus flavipes (Gmelin). Yellow-legs.

A common fall migrant on the coast; less common on the inland waterways.

Earliest record. New Haven, July 26, I894.

Latest record. New Haven, Nov. Io, I883.

The young pass south in August and September, July 30 (1896) to Oct. 13 (1903).

Spring records. May 7, 1877 , near Meriden, on a fresh-water pond (Merriam) ; May 20, I897, New Haven, one seen (L. B. W. ).

Summer record. July 21, I900, North Haven, eighteen taken (H. W. F.).

Helodromas solitarius solitarius (Wilson). Solitary Sandpiper.

A tolerably common spring and fall migrant in May, August, and September.

Spring migration. Earliest record. New Haven, May ro, 1898, April 29, I905 (A. A. S.) ; Portland, May I, I905 ; Litchfield, April 27, I905 (E. S. W.). Latest record. New Haven, May 26, I882; Portland, May I9, I909; Litchfield, May 31, I892 (E. S. W.).

Fall migration. Earliest record. New Haven, Aug. 7, I903; Portland, Sept. 8, 1887. Latest record, New Haven, Oct. 6, 1897; Portland, Oct. I3, I892.

Unusual records. June Io (Grinnell). ${ }^{1}$ East Hartford, July I9, I887, one shot, July I4, I888 (W. E. T.).

Catoptrophorus semipalmatus semipalmatus (Gmelin). Willet.

Connecticut records. Linsley found it breeding at Stratford. Merriam $^{1}$ records that Grinnell took it late in the summer at Milford, and that W. W. C. took a nest containing three eggs at Madison, June 5, 1873. An adult in the Linsley collection of the

1 Merriam, Birds of Conn., p. 108. 
Bpt. Sci. Soc. and a young specimen in the Averill collection of the Bpt. Sci. Soc. were taken at Stratford, the latter on Aug. 9, 1888. Aug. 12, 1887, West Haven, one from a flock of three shot by W. G. Van Name.

Catoptrophorus semipalmatus inornatus (Brewster). Western Willet.

Connecticut records. Sept. 3, 1885, West Haven, one young taken (in coll. of L. C. S.) ; Oct., I888, Fayerweather Island, found dead by Averill (subspecies doubtful) ; Aug. 15, 1897, Stony Creek, two taken from small flock by A. H. V. ( in coll. of A. E. V. and L. B. B.) ; Oct., 1904, West Haven, eighteen taken by A. Ganung [?] ; Aug. 26, 1909, West Haven, one young (W. Ganung, in coll. of L. B. B.).

Bartramia longicauda (Bechstein). Upland Plover. Bartramian Sandpiper.

Formerly a common summer resident, breeding here; now a rare spring and fall migrant, more often heard than seen when migrating.

Spring records. May 2, 1874, Portland, three seen (J. H. S.) ; May 3, I90I, New Haven (L. B. B.) ; May ro, 1905, Litchfield (E. S. W.) ; May 30, 1907, Washington (L. B. B.). ${ }^{1}$

Fall records. Sept. 20, 1882, West Haven (Baldwin); Sept. I, 1886, Guilford (L. B. B.) ; Aug. 30, 1886, Aug. 13, I895, I903, New Haven (L. B. B.) ; Sept. 6, rgor, Litchfield ( E. S. W.) ; Sept. 5, I9Io, Bridgeport, male taken (H. W. B.).

Summer records. Aug. I, I885, Portland (J. H. S.) ; July 3, I888, Litchfield (L. B. W.) ; July 27, 1905, Litchfield (E. S. W.).

Season unrecorded. I873, Stamford, several seen in hands of a taxidermist (Hoyt) ; $1874-6$, Greenwich Point, seen (Hoyt).

Breeding records. Merriam ${ }^{2}$ was informed by W. W. C. (I877) that large numbers of them bred on Plum Island off New London; June 8, I879, Winchester, a set of eggs taken by Williams (H. K. J.) ; May, I902, Torrington, a pair evidently breeding found by Hanson (H. K. J.) ; summer, I904, Litchfield, pair with young seen (reported by E. S. W.).

1 Bird Lore, ix, 5, p. 217.

Merriam, Birds of Conn., p. 109.

3 Job, The Sport of Bird Study, p. 295. 
Tryngites subruficollis (Vieillot). Buff-breasted Sandpiper.

A rare straggler in the fall.

Merriam $^{1}$ (1877) records that J. G. Ely reports two killed near Saybrook "a few years ago," and Dr. Crary has one in his collection shot near Hartford "some years ago."

Sept. 6, 1889, Quinnipiac Marshes, North Haven, a young male taken (E. L. Munson, in coll. of Porter); Sept. 30, I895, same place, a young male (C. C. Trowbridge).

Actitis macularia (Linnæus). Spotted Sandpiper.

A commion summer resident from May to August, the adults almost all going south before the middle of July.

Earliest record. New Haven, April 22, 1889, 1903; Portland, April I8, I899.

Latest record. New Haven, Sept. 27, I882; Portland, Oct. I5, 1895 .

Nest. Eggs laid in a field of grain, the grass of a meadow, or a clump of weeds, usually not far from the water.

Eggs. 4; laid early in June.

Nesting dates. Earliest record. May 24, 1897, four eggs (Hill). Latest record. June 19, 1893, four eggs (Watrous); July 2, I904, two eggs, almost hatched, but deserted (L. B. B.).

Numenius americanus Bechstein. Long-billed Curlew.

The only records for this species in addition to Linsley's record of taking it at Stratford appear in Merriam:1 Capt. Brooks, Faulkner's Island, reported that "occasionally one stops here in the fall;" summer, I873, Milford, seen by Grinnell; Saybrook, sometimes occurs in the fall, but rare (J. N. C.) ; taken near Hartford (Dr. Crary).

A young bird of this species is in the Linsley collection of the Bpt. Sci. Soc.

Numenius hudsonicus Latham. Hudsonian Curlew.

A rare straggler in spring and fall.

Connecticut records. Linsley took it at Stratford, and Dr. Crary at Hartford. 1 Shot at Lyme, Sept. 27, 1853, by J. C. Com-

1 Merriam, Birds of Conn., p. 109. 
stock, and his MS. journal contains this entry: "Lyme, Aug. 16, I858, large flocks of this species" (J. H. S.). Aug. 27, r877, Saybrook, two specimens killed (one in coll. of W. W. C.); June 4, 1886, East Haven, one shot (Mitchell, in coll. of L. C. S.) ; July 26, I890, Quinnipiac Marshes, North Haven, one seen (L. C. S. and Trowbridge) ; c. May 18, 1896, Milford (in coll. of L. B. B.) ; Sept. 19, 1900, New Haven, three shot (seen in market by L. C. S.) ; Sept. 20, 1904, West Haven, young female taken by A. Ganung (in coll. of L. B. B.) ; Sept. I3, Igog, Sept. 4, I9I I, Fairfield (H. W. B.).

Numenius borealis ( $J$. R. Forster). Eskimo Curlew.

Formerly an accidental visitor in the fall migration.

Connecticut records. Linsley took it at Stratford, and J. N. C. has a fine specimen killed at Saybrook, Oct. 13, 1874; Sept., I886, West River Marshes, New Haven, one killed by flying against a wire, given to L. C. S.; Sept. 12, 1889, Quinnipiac Marshes, New Haven, a male taken by E. L. Munson (in coll. of Porter).

\section{Family CHARADRIID压. Plovers.}

Squatarola squatarola (Linnæus). Black-bellied Plover.

The young are sometimes tolerably common along the coast in the fall migration, but the adults are always rare.

Spring migration. Earliest record. New Haven, May 28, 1894. Latest record. New Haven, May 30, I894.

Fall migration. Earliest record. New Haven, Sept. I3, I904; Stamford, Sept. 2, I892 (Porter). Latest record. New Haven, Oct. 21, 1903.

Linsley took it at Stratford. Merriam ${ }^{2}$ recorded the taking of a specimen in the fall (no date) at the mouth of the Connecticut River by W. W. C., and several taken by Dr. F. W..Hall, Oct. 18, 1873. An adult female in the collection of Porter was taken at Stamford, Sept. 2, I892.

Charadrius dominicus dominicus (Müller). Golden Plover. A rare fall migrant; formerly "common during migrations."2 
Fall migration. Earliest record. Guilford, Aug. 27, I883. Latest record. West Haven, Oct. 25, 1909 (A. Ganung).

Merriam $^{1}$ records that Capt. Brooks informed him that they were "plenty at Guilford in spring and early fall," and occasional in the fall, at Faulkner's Island; Linsley found it at Stratford, and W. W. C. recorded it from Portland.

Other records. "Plentiful at Lyme, Sept. I, 1858, 104 being shot on that day by John Grumley" (MS. notes of J. C. Comstock, J. H. S.) ; Aug. 27, 30, 1883, Guilford, three adults seen and one secured (L. B. B.); Oct. 24, 1885, Hartford, a young male flushed from a stubble field (W. E. T.) ;2 Sept. 3, r886, Quinnipiac Marshes, North Haven [?], a young bird taken (A. H. V., in Peabody Museum); Sept. 12, I889, same place, one taken (Munson); Oct: 17, 1893, Portland, one shot (in coll. of J. H. S.) ; Sept. 25 to Oct. 2, 1903, West Haven, about twenty taken (A. Ganung) ; Sept. 20-I, 1904, four young, Oct. 20, 1906, fifteen, Oct. 7, 1907, two, Sept. 15, Oct. 25, 1909, one, all at West Haven (A. Ganung, many of these in coll. of L. B. B.) ; Sept. 19, 1908, Sept. 10, 1909, Sept. 4, I9I I, Stratford (H. W. B.).

\section{Oxyechus vociferus (Linnæus). Killdeer.}

A rather rare summer resident, apparently increasing during the last decade.

Earliest record. New Haven, March 6, 1902; Portland, Feb. 24,1875 (W. W. C.). 1

Latest record. New Haven, Oct. 27, I9II (H. K. J.) ; Middletown, Nov. 6, 1908 (J. H. S.).

Connecticut records. Mr. J. C. Comstock, in his MS. notes, records seeing them at Lyme during the whole winter of $185 \mathrm{I}-2$ (J. H. S.) ; April 5, I875, Middletown, male killed (J. H. S.) ; March 12, I886, Saybrook (J. N. C.) ; Aug. 4, I886, Quinnipiac Marshes, North Haven, one taken (Munson); April 22, 1887, New Haven (L. B. W., one in coll. of L. C. S.) ; April 16, 1888, New Haven (Webb) ; summer, I889, North Haven (Munson); Feb. I, I889, May 23, I902, May 25, July 2, I904, taken, Sept. 15, 1902, Aug. 13, 1903, heard, near New Haven (L. B. B.); Nov., 1892, New Haven (seen in gun store, Dec., by $L$.

1 Merriam, Birds of Conn., p. 102.

$2 A u k$, iv, I, p. 78. 
B. B.) ; July 28,1894 , Bloomfield, adult and young (W. E. T., in coll. of L. B. B.) ; Aug. 18, 1894, East Haven, three shot, Aug. 21, one shot (recorded by H. W. F.) ; July 9, 1896, East Hartford, adult and young (W. E. T., in coll. of L. B. B.) ; May, I901, Newtown (Hamlin); March 6, I902, Stony Creek (in coll. of L. B. B.) ; July 17-I8, 1905, Mt. Tom (H. Sanford) ; Oct. 8, 1906, one, Oct. II, three, Oct. I3, one shot, West Haven (A. Ganung, in coll. of L. B. B.) ; Nov. 6, 1908, Middletown (in coll. of J. H. S.) ; March 18, I9I 1, Milford, male (H. W. B.) ; Oct. 27, I9I I, West Haven (H. K. J.).

Breeding records. According to Merriam, W. W. C. informed him (1877) that it bred on Plum Island and in the vicinity of Portland; Guilford, two eggs collected many years ago (E. C. M. Hall, in Peabody Museum) ; " about twenty years ago," a set of eggs taken in Winchester by Williams (H. K. J.) ;" May 14, 1898, Darien, four eggs taken (Howes) ;3 July, I90I, Bridgewater, nest with four eggs found (recorded by G. L. Hamlin); 1906, Danbury, a pair watched nesting and rearing their young (G. L. Hamlin). Formerly nested in Bloomfield in considerable numbers.

An unusual flight of Killdeer took place along the New England coast the latter part of November, I888. Only two specimens, however, were reported from Connecticut."

Egialitis semipalmata (Bonaparte). Semipalmated Plover.

A common spring and fall migrant along the coast in May, August, and September; rare inland.

Spring migration. Earliest record. New Haven, May II, I897; East Haven, May I, I880 (Woolsey). Latest record. New Haven, June I, r894.

Fall migration. Earliest record. New Haven, July 30, 1896. Latest record. New Haven, Oct. 3I, 1902.

Inland records. June 4,1875 , Portland, female taken by C. H. N. (in coll. of J. H. S.) ; Sept. 17, I891, East Hartford, one shot (W. E. T.) ; May 22, I894, Portland, specimen shot by C. H. N.; June 3, I905, Litchfield (E. S. W.).

1 Merriam, Birds of Conn., p. 102.

3 Job, The Sport of Bird Study, p. 296.

3 Oölogist, xxviii, 1911, p. 151 .

4 Chadbourne, $A u k$, vi. 3, pp. 255-263. 
Ëgialitis meloda (Ord). Piping Plover.

Formerly a summer resident of the sandy beaches; now nearly or quite extinct in the breeding season, and very rare in the migrations.

Connecticut records. Merriam ${ }^{1}$ recorded that it had been found breeding at Stratford (Linsley) and Saybrook (J. N. C.), and W. W. C. has taken it at Portland; Samuels ${ }^{2}$ (I872) stated that it was "pretty abundantly distributed along the coast of New England as a summer resident;" Aug. 29, I886, West Haven, one taken by E. L. Munson; May 28, 1888, Bridgeport, an adult male collected by C. K. A. (in coll. of Bpt. Sci. Soc.) ; Sept., 1904, New Haven Harbor, one seen by L. C. S.

Ochthodromus wilsonius (Ord). Wilson's Plover.

Accidental visitant.

Taken at Stratford by Linsley. ${ }^{1}$ Seen at Bridgeport, July 28 , I888. ${ }^{3}$

Family APHRIZID压. Surf-birds and Turnstones.

Subfamily Arenarinse. Turnstones.

Arenaria interpres morinella (Linnæus). Ruddy Turnstone.

A rather rare migrant frequenting the rocky islands in the Sound. Occasional about inland waters.

Connecticut records. Aug. I4, I883, Faulkner's Island, several (L. B. B.) ; Sept. I, I883, June 27, I884, several (L. B. B.) ; Sept. 9, 1885, New Haven (in coll. of L. C. S.) ; May 24, I886, Saugatuck (in coll. of E. S. W.) ; May I3, I888, Portland, one killed by J. L. Goff; Aug. 20, 1904, West Haven (A. Ganung, in coll. of L. B. B.) ; Sept., 1904, West Haven (seen by L. C. S.) ; Sept. I, 5, I9ro, Stratford (H. W. B.).

\section{Hæmatopus palliatus Temminck. Oyster-catcher.}

The only record is that of Linsley, ${ }^{4}$ who says (I843): "The Oyster-catcher is now rare here, but fifteen years since they were not very uncommon in autumn."

${ }^{3}$ Merriam, Birds of Conn., p. 102.

2 Samuels, Birds of New England, p. 421.

Averill, Birds of Bridgeport, p. 9.

4 Am. Jour. Sci. and Arts, [I] xliv, p. 265; quoted by Merriam, Birds of Conn.. p. 103. 
Order GALLIN E. Gallinaceous Birds.

Suborder Phasiani. Pheasants, Grouse, Partridges, Quails, etc.

Family ODONTOPHORIDE. Bob-whites, Quails, etc.

Colinus virginianus virginianus (Linnæus). Bob-white.

A common resident, especially near the coast, but rather rare in the northwestern part of the state.

Nest. Eggs laid on a bed of leaves, on the ground in a field or meadow.

Eggs. 10-32; in June.

Nesting dates. Earliest record. June 4, 1902, twenty eggs (Beers and J. C. A. M.). Latest record. Aug. 7, 1892, fourteen eggs (Beers).

A nest containing thirty-two eggs of this species (possibly laid by two females) was seen in North Haven by H. W. F. in the spring of 1903 , and on revisiting the nest a few days later he found that all had hatched.

This species suffered severely during the cold winters of 1903-4 and 1904-5, and was almost exterminated over a large part of the state. Since then, and for some years earlier, large numbers of Quail from the South and West have been released, so that now it is impossible to determine what proportion of Connecticut Quail are descendants of the original stock.

Family TETRAONIDÆ. Grouse, Spruce Partridges, Ptarmigans, etc.

Bonasa umbellus umbellus (Linnæus). Ruffed Grouse.

A common resident.

Nest. Eggs laid on the ground under a log or fence or at the foot of a stump in the woods or brush land.

Eggs. 12-16; early in May.

Nesting dates. Earliest record. May 4, I892, fifteen eggs (Beers). Latest record. May 26, I885, thirteen eggs (L. B. B.).

An interesting albino taken by Mr. C. E. Alling, Litchfield, Oct., 1903, is entirely grayish or yellowish-white, the latter shade predominating on the head and upper parts. The dark mark- 
ings of the plumage are plainly indicated in slate gray. Many of the tail feathers, although of full length, are still encased in their pin-feather sheaths, except at the tips.

Bonasa umbellus togata (Linnæus). Canada Ruffed Grouse.

Two Grouse taken by E. S. W. in Litchfield, about Nov. 28, 1906, and given in the flesh to L. B. B., belong to this subspecies, as do others collected there by E. S. W.

\section{Order COLUMBE. Pigeons and Doves.}

Family COLUMBIDE. Pigeons and Doves.

Ectopistes migratorius (Linnæus). Passenger Pigeon.

Formerly very abundant during migrations and occasionally breeding. Now virtually extinct.

The latest definite record we have of the presence of this bird in Connecticut is of one adult male and three young which $\mathrm{Mr}$. Outram Bangs tells us he saw within thirty yards near Willimantic early in October, IgOI.

Mr. Hoyt informs us the last record for Stamford was that of a female shot there in the fall of 1879; a young male taken by Andrew Bassett near Lake Saltonstall in October, I882, is the last taken and preserved near New Haven (in coll. of L. B. B.) ; and a young male shot Oct I, I889, is the last record for Portland (in coll. of J. H. S.).

A flock of about two hundred doves, some of which were certainly Passenger Pigeons, was seen by L. B. B. in North Guilford on Sept. 4, I883; a single bird was seen by him on Prospect Street, New Haven, May I3, I882, and others in Guilford on Sept. II, I883. A pair of very large wild pigeons, believed to be of this species, was seen in East Haven by H. W. F. and L. B. B., May 20, I893. In Portland J. H. S. recorded this species April 7, I6, May I3, and Sept. 26, I887.

As to the abundance of the species at one time, Mr. Henry Townshend tells L. B. B. that his uncles have told him that in the old days it was an easy thing on a "pigeon morning" in September to shoot enough of these birds before breakfast to load a hay-wagon, with the sides on, full to the brim.

"Pigeon mornings" were the cool, frosty mornings of late 
September and early October. To the top of the highest trees on the summit of the low hills east of New Haven long poles were fastened at an angle of about thirty degrees from a perpendicular, and near the bases of these trees huts of leafy branches were built in such a position that the hunter hiding within could rake the pole with a discharge of his gun. The migrating pigeons would alight on these poles, and great numbers were often killed in the early morning hours. Such pigeonambushes L. B. B. well remembers seeing often in the seventies. The pigeons were probably migrating along the coast, and L. B. B. has been told that after stopping for a few minutes on these hills they would fly to the salt-marshes of the Quinnipiac.

Regarding one of the last, if not the last, flight of any size recorded from Connecticut, Mr. Hill writes us. "On the afternoon of September Io, I876, the writer and William Colfax went to Groton, across the river from New London, to shoot plover or shore birds that usually come along about this time during the fall migration. The wind had been blowing heavily from the northwest for some days. Nearing our destination, we observed flocks of birds circling and hovering over the woods near by. Investigation and a shot brought to hand birds we thought and proved to be wild pigeons. We bagged about three dozen, and when we turned homeward we could see flock after flock come along and alight in the woods for food and rest. None flew over the river, for it was near sunset. That evening I made arrangements with Hiram Chappell (still living) to try the pigeons again, and we were on the grounds by daylight next morning, the IIth, and soon the pigeons commenced to fly about, and I shot ninety-six and my friend as many more. It seemed to us that the whole town, as well as the inhabitants of Groton, were out gunning for pigeons. Old flint-locks, queen's arms, and boys with gun locks tied on with string - any kind of firearm that could kill a pigeon was called into service. The height of the flight was on this day. The large flocks were the most wary, flying high in air, and were made up of many small flocks that had evidently been detached and scattered in quest of food, and when on their way to catch up with the main flight their speed was marvelous. The Thames river, at its mouth, the point where the pigeons finally crossed as they flew to the westward, 
is about a mile wide, and many flocks would easily span this distance by one-half or three-quarters of a mile wide. The total number of pigeons in this flight was something wonderful and astounding. I shall never forget it. The flight lasted two days. You ask how many pigeons were in the flight? Seventy-five to one hundred thousand. And how many were killed? Remember the shooting was going on on both sides of the river; say sixty shooters averaged forty or fifty pigeons per man, 2500 per day. Two days, 5000. This is a conservative estimate. Everybody had pigeon pot-pie. As to ammunition, the boys always tell that on the two days the only available shot to be had was buck shot. Ammunition dealers were cleaned out. The crops of the pigeons were filled with acorns. Mr. Chappell and I have gone over the event carefully."

One morning early in the fall during the seventies, possibly at the same date recorded by Mr. Hill, L. B. B. visited Guilford and found the Green strewn with feathers of these birds that had been shot during a flight on the previous day.

On May 6, I897, a dove was flushed by L. B. B. from the borders of a small swamp on the outskirts of New Haven, and to his surprise two eggs were seen lying on a few leaves on the ground in an open space about one foot wide, in a narrow line of alders, that stretched between a small clearing and the swamp. The eggs impressed him as unusually large, and the Mourning Dove is not known to nest on the ground in Connecticut. A few minutes later the bird was again flushed from the nest, and, after flying some distance, showing an unusually white tail, wide spread, as it flew, returned and settled in a tree about thirty yards away. There it was watched for some time through powerful opera-glasses; but the light was not very good and the position in which the bird sat not favorable for study. It was evidently either a Passenger Pigeon or a Mourning Dove, and appeared to be somewhat larger than the latter, and had distinct dark markings near the tips of the outer greater primary coverts. These markings seem to be usually present in females of E. migratorius and not in females of Zenaidura macroura carolinensis. The bird would not allow a nearer approach; and, as the Passenger Pigeon was practically extinct in Connecticut, and had never been known to breed on the ground, L. B. B. de- 
cided he was mistaken in thinking the size of the eggs abnormal, and collected them, as they were not far from a well traveled road. The eggs were well advanced in incubation and one of them slightly nest-cracked. They measure, respectively, I.52 inches by I.I2, and I.5I by I.I2. They are evidently either eggs of the Passenger Pigeon, or eggs of the Domestic Dove which had been substituted by some one for eggs of the Mourning Dove. Dr. Charles W. Richmond, who kindly compared these eggs with a series of eggs of the Passenger Pigeon in the U. S. National Museum, informed L. B. B. that they had more gloss than any eggs of the latter in the collection, but that, as most of these eggs had been taken from the oviducts of birds found in market, this difference was not conclusive. Although there is of course no possibility of certain identification the incident seems worth recording.

An egg in the cabinet of L. B. B. was collected by Mr. A. A. Kellogg of New Haven, in New Hartford before I87o. It measures $\mathrm{I} .43$ by $\mathrm{I} .03$ inches.

In the collection of J. H. S. are two eggs taken by W. W. C. in Portland. One was found May 29, 1873, the male pigeon being on the nest and afterwards shot and mounted; the other June 6,1875 . J. H. S. saw the latter nest, which was on a small tree and not over ten feet from the ground.

Mr. G. L. Hamlin writes that they formerly bred commonly near Neversink Pond. Near Bethel he knew of their last nesting in 1874 , the nest being in a swamp maple near the edge of a small tract of woodland; but the young birds were taken from the nest by a Cooper's Hawk, and that was seen by his father. In September, 1880, he saw the last large flock, some 500 birds. In August and September, 1892, a flock of seven frequented a field of buckwheat near his home in Bethel for about a month, and one bird he shot was in full moult and therefore not preserved. A single bird was seen by him in 1893 , and no more until September, 1902, when for some time a flock of twenty-seven frequented a field of buckwheat and new mown rye. Of this flock all he was able to secure were the feathers of wings and tail of one that had been killed by a hawk. 
Zenaidura macroura carolinensis (Linnæus). Mourning Dove.

A tolerably common summer resident from April to October, decreasing in recent years. Occasionally winters.

Earliest record. New Haven, March 18, 1882; Portland, April 23, I892.

Latest record. New Haven, Oct. 30, I897; Portland, Nov. 30, 1895 .

Winter records. Dec. 19, 1884, Jan. 20, 1896, Portland; Jan. and Feb., 1894, Lake Saltonstall, East Haven (A. J. G.); last week in Dec., 190r, North Haven (Ludington); Feb. 20, 1882, Melrose (Thompson); Jan. 16, I883, Saybrook (J. N. C.) ; ${ }^{2}$ Feb. I6, I9I I, Portland (J. H. S.).

Nest. Most frequently in an evergreen, but occasionally in a deciduous tree or in the fork of a kalmia, at the height of from three to fifteen feet from the ground.

Eggs. 2; in May.

Nesting dates. Earliest record. April 29, 1894, two eggs (L. B. B.). Latest record. July 27 , I889, Norwalk, two fresh eggs (W. I. C.). ${ }^{3}$

\section{Order RAPTORES. Birds of Prey.}

Suborder SARCORHAMPHI. American Vultures.

Family CATHARTID压. American Vultures.

Cathartes aura septentrionalis Wied. Turkey Vulture; Turkey Buzzard.

A rare visitor from the south.

Connecticut records. Linsley recorded it as "not uncommon" when he was a child, "having at that period counted twenty in a flock in Northford in the month of August;" while an old hunter told J. N. C. that they used to be very common about the mouth of the Connecticut; 4 Merriam further records that Dr. W. O. Ayers took one at New Haven in I853, J. N. C. saw them at Saybrook prior to 1873 , Dr. Wood saw one at East Windsor Hill in I874, Rev. J. H. Hand took one at Cromwell,

I $O$. and $O$. , vii, 23, p. $18 \mathrm{r}$.

$2 O$. and $O$., viii, 10, p. 80 .

- Oölogist, vi, 12, p. 231.

4 Merriam, Birds of Conn., pp. 91-2. 
Sept. 23, 1874, at Westbrook, Oct. 16, 18, 1875, and Grinnell reported one taken by Merwin at the mouth of the Housatonic River in June, 1875.

Fall, 1879, Stamford, one seen (Hoyt); April 20, 1882, North Stonington, one shot by O. G. Brown (in Peabody Museum) ;1 March I5, I886, East Haven (L. C. S.) ; Aug., I888, Stamford (Hoyt) ; April 23, I893, Stratford, one seen (Eames); Aug. 3I, I898, Old Lyme, one seen (Brockway) ; Aug. I7, I902, New Milford, one male caught by W. C. Pomeroy (H. K. J., in coll. of L. B. B.) ; Aug. 2I, I902, Torrington, one seen by Hanson (H. K. J.) ;3 Aug. 27, I902, Gaylordsville, one seen by E. H. A. and H. K. J.; summer, 1903, Danbury, one wounded and kept in captivity (J. C. A. M.); May 19, 1907, Danbury, one shot (J. C. A. M., in coll. of L. B. B.).

Catharista urubu (Vieillot). Black Vulture.

Besides the doubtful record referred to by Merriam ${ }^{4}$ of three specimens killed by J. H. Hand at Westbrook, Aug. Io, Sept. I2, 21, I874, the only records for Connecticut are: an adult male, shot by Robert Payne at East Lyme, July 6, I901 (in coll. of Hill) $;^{5}$ and a specimen seen at Bolton reservoir, Oct. 10, I879, by Dr. Wm. Wood (MS. note to J. H. S.).

Suborder FALCONES. Vultures, Falcons, Hawks, Buzzards, Eagles, Kites, Harriers, etc.

Family BUTEONID王. Hawks, Eagles, Kites, etc.

Elanoides forficatus (Linnæus). Swallow-tailed Kite.

Connecticut records. Summer, I86r, Portland, one seen, which "suddenly dove and arose with a snake in its talons," which it devoured in mid-air (H. W. C., recorded by Merriam) ; July 2, I877, Lyme, one seen (J. G. Ely, recorded by Merriam); June I6, I889, Saybrook, one seen, " an unmistakable specimen, gracefully soaring in slowly receding circles; his long, pointed,

10 . and 0 ., vii, 18 , p. $14 \mathrm{r}$.

$2 A u k, \mathrm{xv}, \mathrm{I}, \mathrm{p} .53$.

'Job, The Sport of Bird Study, p. 296.

4 Merriam, Birds of Conn., p. 93.

-Auk, xix, 1902, I, p. 94.

- Merriam, Birds of Conn., pp. 76-7. 
narrow wings, fully expanded tail with the outer feathers of great length, pure white under parts in contrast with the dark upper, presented distinctions so marked from all other native species that recognition was instantaneous and unmistakable" (J. N. C.). ${ }^{1}$

Circus hudsonius (Linnæus). Marsh Hawk.

A tolerably common summer resident from April to October. Occasional in winter.

Earliest record. New Haven, March 22, I884, March I2, I887 (L. B. W.) ; Portland, April I, I882.

Latest record. New Haven, Nov. II, I903; Portland, Nov. 3, 1908 .

Winter records. Feb. 8, 1882, Dec. 18, 1903, New Haven (L. B. B.) ; Dec. 25, 1903, Bristol (F. Bruen).

Nest. Often built of sticks, lined with grass, and located on the ground or on a slight hillock in an open marsh of high grass.

Eggs. 3 to 7 ; the middle of May.

Nesting dates. Earliest record. May 9, I878 (C. L. R.). ${ }^{2}$ Latest record. June 18 , I884, three eggs (C. L. R.). ${ }^{3}$

Accipiter velox (Wilson). Sharp-shinned Hawk.

A tolerably common summer resident from May until October; abundant in the fall migration in September and early October. Occasional in winter.

Earliest record. New Haven, March 19, I904, March 9, I887 (E. S. W.) ; Portland, March 27, I886, I899.

Latest record. New Haven, Nov. 4, I897; Portland, Nov. 23, 1909.

Winter records. Feb. 4, I881, Jan. I9, I887, Feb. 22, I890, Feb. 4, Dec. I3, I895, Dec. 3, 8, I898, Portland (J. H. S.) ; Dec. I3, I900, Woodbridge (Smith, in coll. of L. B. B.); Jan. 14, 1902, Northford (L. B. B.) ; Feb. 22, 1887, New Haven (L. B. W.).

Nest. Almost invariably, in a hemlock or pine tree, occasionally in a maple, to to 50 feet above the ground. Nest made

10 . and $O .$, xiv, 8, p. 123 .

$2 O$. and $O$., ix, 2, p. 16.

$O$. and $O ., \mathrm{x}, 2, \mathrm{p} .25$. 
of hemlock or pine sticks and twigs, the larger ones on the outside, the smaller ones inside, with a small depression for the eggs.

Eggs. 3 to 7 , usually 5 ; toward the end of May.

Nesting dates. Earliest record. May 7, 1896, two eggs (L. B. B.). Latest record. June 26,1883 , three eggs (C. L. R.). ${ }^{1}$

C. L. R. states that " "the first clutch almost always contains five, but, if the eggs are taken successively as laid, the normal clutch may run perhaps to fifteen or eighteen," e. g., May 23, I880, seventeen eggs. ${ }^{1}$

Both ovaries were developed in $\mathrm{I} 7$ of 20 females, chiefly young, examined between 1902 and 1905 by L. B. B.

Accipiter cooperi (Bonaparte). Cooper's Hawk.

A tolerably common summer resident from April to October, though more common during the migrations; occasionally winters. This species is annually becoming rarer over most of the state.

Earliest record. New Haven, March 16, 1887, March 10, I888 (Webb) ; Portland, March I4, I898.

Latest record. New Haven, Nov. I9, I904; Portland, Nov. I2, 1904 .

Winter records. Feb. 20, 1888, Feb. I, I894, Dec. 30, 1902, New Haven (L. B. B.) ; Jan. 12, Ig0I, Portland (J. H. S.) ; Jan. 31, I902, Saybrook (J. N. C.).

Nest. In a hemlock or deciduous tree, usually toward the center of a large piece of woodland; 30 to 70 feet above the ground.

Eggs. 4 to 6 ; usually 4 or 5 ; about the middle of May.

Nésting dates. Earliest record. April 28, I884, one egg (L. B. B.) ; April 30, 1886, three eggs (Eames). Latest record. June 24, I9I I, four eggs (C. G. H.).

A pair of hawks will breed year after year in the same woods, often in the same nest (C. L. R.). . $^{3}$

Frequently several days elapse between the laying of the different eggs of a set, oviposition usually occupying ten days.

1O. and $O$., xiii, 3 , pp. 34-7.

$2 O$. and $O$., vii, 15, p. 117 .

$8 O$. and $O$., ii, 4, p. 25. 
For interesting articles on the nesting and breeding habits of Hawks in this state, consult those of C. L. Rawson, who has made a special study of Hawks in Norwich, as noted in the bibliography.

One instance of the development of both ovaries has been noticed by L. B. B.

Astur atricapillus atricapillus (Wilson). Goshawk.

A rather rare and irregular winter resident, occasionally appearing in considerable numbers.

Earliest record. Oct. 5, 1886, New Haven (L. C. S.).

Latest record. April 12, 1907, Guilford (S. E. Watrous, in coll. of L. C. S.).

Large flights recorded in January, 1897 , especially in the northern and eastern parts of the state (J. H. S.) ; in early November, 1906, and on through to March, I907, near New Haven (L. B. B.) ; and in the fall of 1907 , in different parts of the state (J. H. S.).

There are about thirty-five records of this species being either seen or captured in this state.

Breeding record. $\mathrm{H}$. K. J. ${ }^{1}$ records that "Mr. Williams found a nest in Winchester, about fifteen years ago [about I8937. It was in a chestnut tree, sixty feet up, and contained two eggs. He shot the female for identification, and has the eggs and complete data."

Buteo borealis borealis (Gmelin). Red-tailed Hawk.

A common resident of the wooded hills of the interior of the state; much rarer on the coast except in the fall migrations.

Most abundant (Portland) from April I5 to May 25, and from Oct. I to Nov. 25, although recorded there during the entire year. The majority pass through the state as migrants, but this species winters regularly in small numbers throughout the state, and is more common on the coast at that season than in summer.

Nest. Very large nest of sticks and twigs, usually in a deciduous tree, from 45 to 75 feet from the ground. It favors

${ }^{1} \mathrm{Job}$, The Sport of Bird Study, p. 297. 
"dry hillsides where the woods are rather open and a wide range of view can be had." (C. L. R.) $)^{1}$

Eggs. I to 3; early in April.

Nesting dates. Earliest record. March 24, 1903, two eggs (Beers). Latest record. April 30, I888, two eggs (Eames); May 23,1873 (W. W. C.). ${ }^{2}$

This species will occupy the same nest year after year unless disturbed, when it will build another nest in the vicinity (W. W. C. ${ }^{2}$ and C. L. R.). ${ }^{3}$

Mr. Rawson also notes the facility with which they are mated when one of the pair is killed, the survivors often pairing within a week or two, leading to the supposition that the old ones probably pair with the young of previous years. ${ }^{3}$

Buteo lineatus lineatus (Gmelin). Red-shouldered Hawk.

A common resident of the lowlands of the larger river valleys and the marshy woodlands of the coast; the majority passing farther south in October and returning in March, but many wintering regularly throughout the state.

In breeding these hawks return regularly to the same woods, and often use the same nest as the previous year, unless that was robbed. In that case they usually take the one in which they had succeeded in raising their second set, or the nest occupied in an earlier year. If the first set is taken, a second set is laid in from three weeks to a month.

The following nesting records are a summary of II 2 occupied nests of this species examined by L. B. B., as well as about 60 examined by C. L. R."

Nest. Location: all in deciduous trees; chestnuts $(72, \mathrm{~L} . \mathrm{B}$. B., 39, C. L. R.), oaks (22, L. B. B., ro, C. L. R.), maples (9, L. B. B., I, C. L. R.), beeches (I each), yellow birch, ash, and hickory. Height: average, 35-50 feet from the ground, with the extremes of 20 (C. L. R.) and 75 (L. B. B.). Situation in tree: usually in the forking of the trunk at the top of the tree, frequently lower down against the trunk at a point where two or

10. and 0. vi, 5 , p. 37 .

${ }^{2}$ Merriam, Birds of Conn., pp. 85-6.

$\because O$. and $O$., ii, 4, p. 25 .

$O$. and $O$. , xvi, 1, pp. $1-19$. 
more branches leave it, very rarely in the fork of a limb at some distance from the trunk (L. B. B.). Material: sticks, frequently lined with pieces of hemlock, cedar, pine, or ground pine $(83$, L. B. B.), or without evergreen (II, L. B. B.), or lined with leaves (C. L. R.). Oftentimes feathered. Old nests of crows and other hawks often utilized.

Eggs. 2-5, usually 3 or 4 ; about the middle of April. Set of 5 (L. B. B.), sets of 4 (I7, L. B. B., I4, C. L. R.), sets of 3 (57, L. B. B., 27, C. L. R.), sets of 2 (25, L. B. B., I3, C. L. R.), sets of I (3, L. B. B.). Eggs from the same wood and probably from the same birds have usually a certain resemblance in size, color, or markings. The number of eggs in the first set seems to depend largely on the weather in March, a warm open March with little snow being followed by large sets, a cold and stormy March by small sets. The most heavily marked egg is usually laid first.

Nesting dates. Earliest record. March 30, 1894, two eggs (L. B. B.). Latest record. May 6, I901, two eggs (L. B. B.). Late sets. May 28, I899, four eggs (Hill, New London) ; June I, I884, two eggs (C. L. R., Norwich).

In actions at the nest these hawks vary greatly individually; some leaving silently almost as soon as one enters the woods and not returning, others waiting until the tree is struck before leaving the nest, when they perch near by, crying frequently, and swooping to within ten feet of the climber. As a rule, however, the degree of solicitude shown depends on the length of incubation of the eggs; the nearer the eggs are to hatching, the more anxiously the hawks protect them. .

The egg of a Barred Owl in the nest of a Red-shouldered Hawk has twice been found by L. B. B.; both times in the same piece of woodland, which had been reduced from an extensive tract by wood-choppers, thus leaving few suitable nesting-places for large birds. One (April 13, I90I) contained three eggs of the Hawk and one of the Barred Owl, with the Owl on the nest; the other (April I, I902) contained two eggs of the Hawk and one of the Barred Owl, with the Red-shouldered Hawk on the nest. As the hawks' eggs were in both instances further advanced in incubation, this species was probably the original owner of both nests. 
During the winter these hawks seldom circle high in the air, as is so common at other seasons of the year, although they have been noticed doing this (Feb. I4, I903, L. B. B.).

Mr. C. L. Rawson of Norwich, who has made an extensive study of the hawks in that vicinity, has recorded in his numerous articles in $O$. and $O$. a considerable mass of interesting data on eggs of this species, peculiar markings, and the recurrence of these markings in one individual. Other data as to the number and description of eggs taken from the same bird in successive years are numerous, as well as descriptions of nests and their location. We refer those interested in the subject to his articles as recorded in the bibliography.

Buteo platypterus (Vieillot). Broad-winged Hawk.

A tolerably common summer resident from May to September, and common fall migrant in September; breeds most abundantly in Litchfield county.

Earliest record. New Haven, April 21, I888; Portland, April 19, I893.

Latest record. New Haven, Oct. 16, I901, Nov. 13, 1906 (E. S. W.) [?] ; Portland, Oct. 22, 1892.

Nest. Situated in the center of the deepest woodland accessible. They vary in material from nests like those of the Redshouldered Hawk, well-lined with various soft materials, to others resembling those of Cooper's Hawk, a loose platform of sticks lined with a few square pieces of bark.

Eggs. 2 or 3; about the middle of May.

Nesting dates. Earliest record. April 19, I884, one egg, later three (L. B. B.) ; May 6, 1900, two eggs (Blackwood); May 14, I894, three young, ten days old (G. L. H.). Latest record. June 16,1898 , two eggs (H. W. F.).

The bird is very shy and is seldom seen on the nest.

One bird of this species with both ovaries developed has been found by L. B. B.

This species frequently predominates in the hawk flights described by C. C. T. ${ }^{1}$ 
Archibuteo lagopus sancti-johannis (Gmelin). Roughlegged Hawk.

A rather uncommon winter resident, living about the larger marshes from November to March.

Earliest record. New Haven, Nov. 4, I897. Latest record. New Haven, March 8, I901, April 20, I889 (L. C. S.).

Connecticut records: Dr. Wood of East Windsor Hill occasionally found it abundant in that locality, ${ }^{1}$ and took about forty specimens ; ${ }^{2}$ Merriam $^{1}$ saw it near New Haven, Nov. 20, I875; Dec. 25, 1875, Feb. 16, I880, specimens killed near East Windsor Hill (in coll. of J. H. S.) ; Sept., 1879, Stamford, one taken (recorded by Hoyt); Sept. (?), I883, Saybrook (in coll. of J. N. C.) ; Oct., I884, near Stamford (Hoyt, in coll. of L. B. B.) ; March 30, 1887, Glastonbury (in coll. of J. H. S.) ; Feb. I7, I888, New Haven (in Flint coll. of Brewster); April 20, I889, New Haven (in coll. of L. C. S.) ; Nov. I6, I892, Stamford (Schaler, in coll. of Porter); Dec. 8, 1894, New Haven (A. H. V., in coll. of L. B. B.) ; Jan. 3I, 1895, Nov. 4, 1897, Jan. 16, 1899, Jan. 24, 1900, March 8, 1901, Feb. 7, Dec. I, Dec. I8, 1903, between New Haven and Guilford (seen by L. B. B.); Dec. 24, I896, Fair Haven, seen in taxidermist's shop (L. B. B.) ; Nov. 20, I90I, Cromwell, two (in coll. of J. H. S.) ; Feb. 24, March 6, I906, New Haven (E. S. W.).

Aquila chrysaëtos (Linnæus). Golden Eagle.

A rare winter visitant.

Connecticut records. Winter, 1856-7, Hartford, adult taken, seen in the flesh by J. C. Comstock (J. H. S.) ; Dr. Wood occasionally saw it about Hartford (prior to 1877 ); Nov. I3, I875, Deep River, one shot (in coll. of H. W. F.) ; May, 1877, Saybrook, one seen (J. N. C.) ; 1879 , Southbury, female shot (Wood coll.) ; Oct. 29, 1881, Ragged Mountain, Barkhamsted, one young shot by $\mathrm{H}$. Wedge of Riverton; 5 Nov., I884, and Nov. 5, I896, Stamford, two taken (recorded by Hoyt) ; Oct., I887, Preston, one shot (in coll. of G. H. Martin) ; ${ }^{6}$ Nov. I, I892,

${ }^{1}$ Merriam, Birds of Conn., pp. 87-8.

2 Samuels, Birds of New England, p. 576.

O $O$ and $O$., viii, 10, p. 80 .

4 Merriam, Birds of Conn., p. 89.

$5 O$. and $O$. , vi, 10, p. $76 ; 12$, p. 94 (more fully described).

- $O$. and $O$., xii, 12, p. 206. 
Essex, adult female (in coll. of J. H. S.) ; Oct. I, I896, Woodbridge, one female shot (in coll. of A. E. V.) ;1 Nov. 20, I896, East Haven, young male trapped (in coll. of L. C. S.) ; Jan. 19, 1897, Salem, adult male trapped (in coll. of C. L. R.) ; Oct. 9, 1909, East Haven (in coll. of L. C. S.).

Haliæetus leucocephalus leucocephalus (Linnæus). Bald Eagle.

A rather rare spring and fall migrant and occasional summer resident; formerly bred in more unsettled parts of the state, possibly a few still breeding.

Earliest record. New Haven, April I7, I885; Portland, April 25, I889; South Glastonbury, March I6, I899 (seen by J. H. S.).

Latest record. New Haven, Sept. Io, I883, Nov. 20, I875 (Merriam). ${ }^{3}$

Winter records. Jan. 26, Feb. 25, I891, Stamford (Hoyt); Dec. 25, I893, Middletown (J. H. S.).

Summer records. Numbers of this species have been seen during May, June, July, and August, at various places in the state (Deep River, Haddam Neck, Litchfield, Middle Haddam, Middletown, New Haven, North Haven, Portland, Saybrook, Stratford, Stevenson) in I880, I882, I883, I886, I888, I890, I89I, I905.

Breeding record. Job records" that "Late in April, about a dozen years ago (1896), Mr. Williams found in Winsted a nest on a rocky ledge which contained two good-sized young. Several years previously he had found another nest in an unclimbable tree, and also has seen young which could not have been raised far off."

Haliæetus leucocephalus alascanus C. H. Townsend. Northern Bald Eagle.

A young female was shot near Willimantic, Oct. 27, I909, by G. H. Champlin, and sent to L. B. B. in the flesh by C. R. H. That the majority of Connecticut Bald Eagles belong to this subspecies, is the belief of L. B. B.

I $A$ k, xiv, I, p. 89.

2 Auk, xiv, 2, p. 215.

- Merriam, Birds of Conn., p. 90.

${ }^{4} \mathrm{Job}$, The Sport of Bird Study, p. 297 
Family FALCONIDÆ. Falcons, Caracaras, etc.

Subfamily Falconinæ. Falcons.

Falco rusticolus obsoletus Gmelin. Black Gyrfalcon.

There are only two records for this state: Winter, I879, west of Stamford ( $1 / 4$ mile over the boundary in New York State, but probably driven there from Connecticut by the northeast gale then raging), killed by Dr. Chas. Rowell (seen by L. B. B.) ; Jan. 27, 1907, Durham, female shot by A. Banks (in coll. of J. H. S.). ${ }^{1}$

Falco peregrinus anatum Bonaparte. Duck Hawk.

A rare but probably regular fall migrant; a very rare summer resident.

Fall migration. Earliest record. New Haven, Sept. 29, 1903; Lyme, Sept. I4, I895 (W. E. T.). Latest record. Guilford, Oct. 30, 1907 (L. C. S.).

Winter records. Feb. 23, I876, Milford (Grinnell) ; Jan. 19, I894, Stamford (in coll. of Porter).

Spring records. April 30, 1886, Portland, male shot (in coll. of J. H. S.) ; May 9, I888, Mt. Carmel (Webb and Searles); May 9, I899, Mt. Carmel (Bernard); May, I900, Hamden (Osborne); spring, I9ıo, Mt. Carmel (H. K. J. and Buttrick).

Nest. Eggs laid on a shelf of some precipitous cliff.

Eggs. 2-4; early in May.

Breeding records. May 25, I86I, Talcott Mt., near Hartford, four young (Moses, recorded in Hartford Times, June 29, I86r, and by Merriam) ;2 summer, I863, same locality, two pairs breeding (Dr. Wood) $;^{3}$ May r, r872, Talcott Mt., three eggs taken by P. H. Woodford (J. H. S.) ; May 9, I888, Mt. Carmel, three eggs (Webb and Searles, in coll. of $\mathrm{L}_{\text {. }}$ B. B.) ; May 9, I899, Mt. Carmel, two eggs (Bernard, in coll. of L. B. B.) ; spring, I9Io, Mt. Carmel, one pair and empty nest (H. K. J. and Buttrick).

Falco columbarius columbarius Linnæus. Pigeon Hawk.

A tolerably common spring and fall migrant, most abundant in October. Occasional in winter.

s Samuels, Birds of New England, p. II. 
Spring migration. Earliest record. New Haven, March 30, 1904; Portland, April 24, 1873. Latest record. New Haven, April 25, I885; Portland, May 25, 1882.

Fall migration. Earliest record. New Haven, Sept. Io, 1902; Portland, Sept. 9, 1899. Latest record. New Haven, Nov. 6, I901 ; Portland, Nov. 6, 1876.

Winter records. Dec. 24, I875, Portland; March 4, I885, New Haven; Jan. 5, I897, Portland; Dec. 6, 1900, and Jan. I7, 1905, New Haven; Dec. 25, 1903, Bristol (E. A. Smith).

Falco sparverius sparverius Linnæus. Sparrow Hawk.

A tolerably common resident, most frequently seen in the early spring and the late fall. More common in the northern half of the state.

J. H. S. and L. B. B. record this species during the entire year.

Nest. Hole in tree, oftentimes the deserted nest of a Flicker or other bird.

Eggs. 3 to 5 ; early in May.

Nesting dates. Earliest record. April 29, 1890, five eggs (Trowbridge). Latest record. May 20, 1882, five eggs (J. H. S.) ; July 4, 1900, four young (Hill).

This species was formerly rare, Merriam ${ }^{1}$ thus characterizing it, adding that it breeds near Portland (W. W. C.) and sometimes near East Windsor Hill (Wood). Between 1890 and 1900 , however, it became somewhat if not very common during migrations, and since then has been frequently noted. It is still comparatively rare as a breeder in this state.

\section{Family PANDIONIDA. Ospreys.}

Pandion haliaëtus carolinensis (Gmelin). Osprey.

A tolerably common spring and fall migrant; a rare summer resident near the coast in the southeastern part of the state.

Spring migration. Earliest record. New Haven, March 24, I904; Portland, March 25, 1903. Latest record. New Haven, May .30, I901 ; Portland, May 20, 1882.

Fall migration. Earliest record. New Haven, Aug. 27, 1895; 
Portland, Aug. I I, I897. Latest record. New Haven, Oct. I8, I888; Portland, Oct. I8, I893; Danbury, Nov. I3, I892. ${ }^{1}$

Eggs. 2 to 4 ; early in May.

Nesting dates. Earliest record. April 22, 1897, three eggs (Hill). Latest record. July 4, I870 (F. S. Smith). ${ }^{2}$

They do not breed in the vicinity of Portland (W. W. C. and J. H. S.), nor along the Connecticut River, except near its mouth, where J. H. H. reports a colony of twenty-two pairs at Niantic. C. L. R. reports them breeding commonly along the shores of the Sound in New London County, and in several swamps a dozen miles in the interior up the Thames River valley. ${ }^{3}$ Mr. Williams has known a pair to nest in Litchfield County. ${ }^{4}$ L. B. B. saw a specimen in Warren, Litchfield County, June 7, I900, and E. S. W. saw one in Litchfield, July I, I893, and July 4 , 1905. These last are our only inland records during breeding season.

\section{Suborder STRIGES. Owls.}

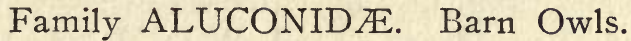

Aluco pratincola (Bonaparte). Barn Owl.

A very rare accidental visitor from the south.

Connecticut records. Merriam ${ }^{5}$ notes the following: Linsley took it at Stratford; about I84I, Hartford (Ayres) ; Oct. 28, I868, Sachem's Head (in coll. of Wood); "some years ago" (before I877), Madison (in coll. of Capt. Brooks).

Later records. About 1875, Stamford, one taken (Schaler); June I5, I891, Leesville, one shot by W. Chase (in coll. of J. H. S.) ; Aug. 28, I89I, Litchfield, one shot (in coll. of L. B. W.) ; I892, Winsted, nest with six young in an old factory found by H. Kinney (H. K. J.) $;^{7}$ I893, same locality, same nest, set of seven eggs taken by Williams (H. K. J.) ; June 25, I896, Portland, a young male taken (in coll. of J. H. S.) ; Sept. II, I903, Stratford, male (in coll. of L. C. S.) ; Sept. I4, I906, Portland,

1O. and $O$, , xvii, II, p. 172 .

2 Merriam. Birds of Conn., p. 88.

O. and $0 ., \mathrm{x}, 6, \mathrm{p} .89$.

Job, The Sport of Bird Study, p. 297.

- Merriam, Birds of Conn., pp. 66-7.

- Auk, ix, 2, p. 202.

${ }^{7}$ Job, The Sport of Bird Study, p. 298. 
one shot (in coll. of J. H. S.) ; Jan. I5, I9II, East Hartford, one taken (in coll. of J. H. S.). C. L. R. has recorded several specimens from New London County.

Family STRIGID瓜. Horned Owls, etc.

Asio wilsonianus (Lesson). Long-eared Owl.

A common winter and rare summer resident.

Earliest record. New Haven, Oct. 25, I904; Portland, Oct. 8, I892.

Latest record. New Haven, March 21, I904; Portland, March 25, 1875 .

Nesting records. April (prior to I877), Berlin, nest with four eggs (Brandegee) ; April 25, 1880, Ellington, five eggs taken (J. M. Wade) ;2 spring, I88I, Bristol, a set of eggs taken (E. N. Brandegee); May 9, I886, Woodbridge, nest with four young (Augur) ; May, I890, Northford, set of four eggs (Trowbridge, in Trinity College Museum).

Other summer records. July I, I885, Litchfield (L. B. W.); April 24, 1906, New Haven (L. B. W.) ; May I, 1906, North Haven (L. B. B.).

Asio flammeus (Pontoppidan). Short-eared Owl.

A common fall and tolerably common spring migrant; most frequently noted in October and March; winters rarely.

Spring migration. Earliest record. New Haven, March 2, 1894, Feb. I7, 1905 (Sherman); Portland, Feb. 9, I9I I. Latest record. New Haven, March 3I, I896; Portland, April 29, I883.

Fall migration. Earliest record. New Haven, Sept. 7, I906; Portland, Oct. 8, I89o. Latest record. New Haven, Nov. 29, I884; Portland, Dec. I2, I903.

A favorite haunt of these birds is the salt-water marshes, where they sometimes congregate in flocks. Between sixteen and twenty of these Owls were found by L. B. B. in the marshes at Guilford, Oct. 17, I890, more than half of them being within a space twenty yards square.

Breeding records. "Nests on the ground. Not uncommon" (Merriam). ${ }^{3}$ Dr. William Wood of East Windsor Hill recorded ${ }^{4}$

1 Merriam, Birds of Conn., pp. 69, 70.

20 . and 0 ., vii, pp. $16 \mathrm{r}-2$.

- Merriam, Birds of Conn., p. 70.

40 . and 0 ., ix, 1 , pp. I0-Ir. 
that a nest was found "some thirty years ago" half a mile from his office, the nest being on elevated ground, in a meadow, and composed of fine grass, and containing four eggs; 1876 , an egg presumably of this species found in the grass at Groton Long Point, and brought to C. L. R. ${ }^{1}$

Strix varia varia Barton. Barred Owl.

A common resident along the coast; rarer in the interior, where it is most common during October and November.

Nest. Usually in a hollow tree or in the deep crotch of a tree; frequently in old hawks' nests; most common location a chestnut tree; height from the ground, 6 to 45 feet; nest often heavily feathered, and so deep as to hide bird from observation.

Eggs. 2-4 (of 22 nests recorded by C. L. R., ${ }^{2} 7$ contained 3 eggs and I 5 contained 2 eggs each); March 25-April I 5 .

Nesting dates. Earliest record. March I7, I886, one egg (L. B. B.). Latest record. May Io, I879, two eggs (C. L. R.).

J. N. C. wrote L. B. B. that he considered this species "the most destructive enemy of birds, game, and domestic fowls among all the Hawks and Owls."

In the winter the numbers of the resident birds are often augmented by a flight from the north. This was the case in the winter of 1882-3, when twenty-six were brought to Mr. Herrman, then taxidermist of the Peabody Museum; and again in the fall of 1894 , when twenty-five were brought to A. H. V. to be mounted.

Scotiaptex nebulosa nebulosa (J. R. Forster). Great Gray Owl.

A very rare straggler from the north.

Connecticut records. Jan. 6, 1843, Stratford, one taken (Linsley);3 Jan. 22, 1893, North Haven, a male secured by a farmer (A. H. V., in Peabody Museum); March, 1907, East Haven, one secured by an Italian and sold to a restaurant in New Haven, where it was purchased, a then freshly mounted specimen, by L. C. S.

1O. and $O$., $x v i, 4$, p. 59 .

$2 O$. and $O ., x, 2$, p. 25 ; xiii, 3 , pp. $37-40$.

${ }^{3}$ Am. Jour. Sci. and Arts, [1] xliv, 2, p. 253; recorded by Merriam, Birds of Conn., p. 70. 
Cryptoglaux funerea richardsoni (Bonaparte). Richardson's Owl.

An extremely rare accidental visitor.

The only records for this state are: mid-winter, about I860, near East Windsor, one captured and presented to Dr. Wood: 1 Nov. 12, 1906, Kent, a male found dead by an Indian woman (obtained by H. K. J., in coll. of L. B. B.). ${ }^{2}$

Cryptoglaux acadica acadica (Gmelin). Saw-whet Owl.

A rather rare resident, most frequently observed in the winter, but breeding rarely.

Of the 42 records which we have for this species, 39 were between October 12 and March 28, the other 3 being summer records. This Owl has been recorded from the vicinity of Portland (I9 times, J. H. S.), New Haven (9), Stamford (3), Bridgeport (2), Milford (2), Chester, Stony Creek, Fairfield, Winsted (I each), Litchfield (4), thus showing a pretty general distribution. Merriam ${ }^{3}$ is of the opinon that the apparent scarceness of the bird may rather be due to its "diminutive size and nocturnal habits."

Summer records. April I, I894, Chester, a set of five eggs taken by H. Bennett (in coll. of H. W. F.) ; June 8, I896, Bridgeport, one seen, and later its nest probably identified (Beers); May, I895 (?), Winsted, a pair with three young seen in an old Crow's nest (Williams). ${ }^{4}$

These little owls seem to suffer both from the weather and from the persecution of larger owls. One in the coll. of Porter was found dead in very cold weather, and their remains have been found in the woods several times by L. B. B. One found April 10, I893, had been apparently killed by an owl; and another was found in the stomach of a Barred Owl, which had been shot at Lake Saltonstall, March 3, 1883 .

Development of both ovaries has been seen once by L. B. B.

Otus asio asio (Linnæus). Screech Owl.

A tolerably common resident.

Nest. In a hollow tree, most frequently an apple tree in an orchard.

${ }^{1}$ Merriam, Birds of Conn., p. 73.

2 Job, The Sport of Bird Study, p. 298.

'Merriam, Birds of Conn., p. 74.

${ }^{4} \mathrm{Job}$, The Sport of Bird Study, p. 299. 
Eggs. 4 or 5 ; the last of April.

Nesting dates. Earliest record. April 9, I910, three eggs (C. G. H.). Latest record. May 9, 1892, two eggs (Beers).

This species frequents even our largest cities, as one was seen by L. B. B. on New Haven Green on the evening of Feb. 22, I885, and another on April 3, I893.

Bubo virginianus virginianus (Gmelin). Great Horned Owl.

A tolerably common resident, especially of the wilder portions of the state.

Nest. This owl usually occupies the old nest of a hawk, crow, or squirrel, though occasionally building for itself. Height: 45-75 feet from the ground. Location: most frequently in a hemlock or pine, or perhaps a chestnut or cedar.

Eggs. 2-3; last of February or early in March.

Nesting dates. Earliest record. Feb. 19, 1877, two eggs (J. H. S.) ; March 9, I904, three young (L. B. B.). Latest record. April 25, 1902, two eggs (Hill).

L. B. B. and H. K. J. have both noted an unusual habit of the parent birds in apparently destroying the nest when the young become old enough to balance themselves in the fork of the tree, thus removing the conspicuous nest and leaving the bird well protected by the harmony of its colors with the bark of the tree.

\section{Nyctea nyctea (Linnæus). Snowy Owl.}

At present a rather rare and irregular winter resident, probably absent most winters, but occasionally occurring in considerable numbers, especially along the coast. Most frequently recorded in November and December.

Earliest record. Stamford, Sept. I8 (Schaler), Oct., I874 (Hoyt). Latest record. Branford, April I5, 1902 (G. V. Smith).

Recent records. Although this species was noted pretty regularly up to 1890 or thereabout, records in later years have been growing increasingly scarce. During the winter of I90I-2 large numbers of Snowy Owls appeared on the New England coast and not a few of them reached Connecticut'; captures were reported during this period from Stonington, Mystic, Noank, New London, and Niantic by Hill, from Saybrook by J. N. C., from Clinton by J. Peck, from Milford by L. C. S., and from Branford 
by L. B. B. About April I5, 1902, Branford (G. V. Smith); Nov. 18, 1905, Nov. 20, 1906, Portland (J. H. S.) ; Nov. 19, 1905, Stamford (Porter); Nov., 1905, New Haven (L. C. S. and L. B. B.) ; Dec. 23, 1905, Danbury (J. C. A. M.) ; Nov. 22, 1910, New Haven (Minor).

\section{Surnia ulula caparoch (Müller). Hawk Owl.}

The following are the only records for this state: Nov., I869, New Haven, bird secured by Dr. F. W. Hall (recorded by Merriam $^{1}$ as the first Connecticut specimen); winter, I879, near Stamford, one seen at a distance of twenty feet in flight and plainly identified (Hoyt).

\section{Order COCCYGES. Cuckoos, etc.}

\section{Suborder CuculI. Cuckoos, etc.}

Family CUCULID无. Cuckoos, Anis, etc.

Subfamily Coccrzinæ. American Cuckoos.

Coccyzus americanus americanus (Linnæus). Yellowbilled Cuckoo.

A tolerably common summer resident from the middle of May to the middle of September.

Earliest record. New Haven, May Io, I894, May 8, I894 (A. H. V.) ; Portland, May 7, 1895.

Latest record. New Haven, Oct. I6, I900; Portland, Oct. I7, I894.

Nest. Usually in a bush or slender tree in a thicket; height from ground, 5 to ro feet (one 40 feet); composed of sticks and twigs, and just large enough to hold the eggs.

Eggs. 3-5; usually early in June.

Nesting dates. Earliest record. May 24, 1898, four eggs (J. H. H.). Latest record. Aug. 26, 1889, two eggs (W. I. C.) ${ }^{2}$

Unusual records. June 7,1894 , a nest containing two eggs of this species and two of the Black-billed Cuckoo, with the female Yellow-billed sitting, was found by L. B. B.; about 1877 , a single egg found in a Robin's nest along with eggs of the latter 
species (L. B. B.) ; two nests with five eggs each, found in summer of 1884 (C. E. L.). ${ }^{1}$

In a single apple tree, J. C. A. M. found, June I5, I902, nests containing either eggs or young of the Yellow-billed Cuckoo, the Scarlet Tanager, Robin, Baltimore Oriole, Wood Thrush, and Least Flycatcher.

Coccyzus erythrophthalmus (Wilson). Black-billed Cuckoo. A common but irregular summer resident from the middle of May to August; not nearly as plentiful now as in the nineties. Earliest record. New Haven, May Io, 1904, May 7, 1905 (A. A. S.) ; Portland, April 23, I886; Litchfield, May 9, I905 (E. S. W.).

Latest record. New Haven, Sept. 14, 1903, Sept. 21, I907 (A. A. S.) ; Sept. 28, 1875 (Merriam) ;2 Portland, Sept. I9, I899; Litchfield, Sept. 2I, I89I (L. B. W.) ; East Hartford, Oct. 3, I887 (W. E. T.).

Nest. In a small bush or young tree in a thicket or occasionally in an orchard; 2 to 12 feet from the ground.

Eggs. 2-4, usually 3; early in June.

Nesting dates. Earliest record. May I8, I89I, one egg (J. C. A. M.). Latest record. Aug. 2, I88I, three eggs (L. B. B.).

Unusual records. May 29, 1896 , nest containing three eggs of C. erythrophthalmus and one of C. a. americanus, and June 6, I897, two eggs of the former with one of the latter (L. B. B.), in both instances the Black-billed Cuckoo being on the nest; June 7, I893, nest containing seven eggs of the Black-billed Cuckoo (L. B. B.) ; June Io, I894, three eggs, of which one measured only .75 by $.6 \mathrm{I}$ inch (J. C. A. M.).

Suborder ALCYONES. Kingfishers.

Family ALCEDINID瓜. Kingfishers.

Ceryle alcyon (Linnæus). Belted Kingfisher.

A common summer resident from April to October; rarely wintering.

Earliest record. New Haven, April 3, I902, March 27, I907 (A. A. S.) ; Portland, April 5, 1893.

$1 O$. and $O$., ix, to, p. 128.

- Merriam, Birds of Conn., p. 63. 
Latest record. New Haven, Nov. 4, Igor, Nov. I3, I875 (Merriam) ; 1 Portland, Nov. 22, I895.

Winter records. Feb. 13, I874, Hartford (Humphrey); Jan. I4, I883, Portland (W. W. C.) ; Jan. I5, I883, Middletown (C. H. N.) ; Feb. I4, 1888, Seymour (Eames) ; Feb. 17, 1902, Saybrook_(J. N. C.) ; Jan. 17, I905, Stamford (Vanhavenberg, recorded by Hoyt) ; winter, I905-6, a number wintering in Stamford (Porter); Jan. 20, I906, North Haven (E. S. W.) ; New Haven, one seen, Dec. 25, 1905-March 7, 1906, and Dec. 5, I906-March I7, I907 (A. A. S.).

Nest. A burrow excavated in a sand-bank to the depth of $4 \frac{1}{2}$ to 7 feet; no nesting material as a rule for fresh eggs, while those incubated repose on a mass of small fish bones and scales.

Eggs. 4-Io, usually 7; latter part of May.

Nesting dates. Earliest record. May 9, I881, six eggs (Beers). Latest record. July 2, I88I, seven young (L. B. B.).

Unusual records. June, I88I, Litchfield, nest with ten young (L. B. W.).

May Io, I904, a hole was found in a sand-bank near New Haven by L. B. B. about which a pair of Rough-winged Swallows were flying. Early in the morning of Monday, May 23, neither hole nor swallows were to be seen, all evidence of the former having disappeared by the caving of the bank, caused by the removal of sand. After some effort the entrance was found, a stick passing easily through the loose sand that concealed it. At a depth of about five feet a male Kingfisher was found sitting on seven eggs and a round pebble about the size of an egg. This bird must have remained there imprisoned since the carting of sand ceased on Saturday, although with one stroke of its powerful bill it could have regained its freedom, to burrow out being, apparently, beyond its mental power.

Order PICI. Woodpeckers, Wrynecks, etc.

Family PICID㤅. Woodpeckers.

Dryobates villosus villosus (Linnæus). Hairy Woodpecker.

30 and $O$., viii, 4 , p. 32 . 
A tolerably common resident; apparently more numerous in the winter.

Nest. In a cavity in a living limb, but usually a short distance below a dead limb of sufficient size to affect the density of the wood below. Location, an apple tree in an orchard or a deciduous tree in the woods. Height from ground, usually between $\mathrm{I}_{5}$ and 30 feet.

Eggs. 2-4; early in May.

Nesting dates. Earliest record. April 30, I904, two eggs (L. B. B.). Latest record. May 30, rgor, four eggs (Hill).

Dryobates pubescens medianus (Swainson). Downy Woodpecker.

A common resident.

Nest. Usually in the dead limb of a tree in the orchard, woods, or along the roadside. (Of $\mathrm{I} 3$ nests recorded by $\mathrm{J} . \mathrm{H}$. S. six were located in willow trees or stumps, the remainder in poplars, maples, and black birch trees.) Height from ground, ro-40 feet. Building, April 30 - June 3.

Eggs. 4-5; the last of May.

Nesting dates. Earliest record. May I6, I896, five eggs (H. W. F.) ; May I6, I899, five eggs (Hill). Latest record, June 12, I882, four eggs (J. H. S.).

Both the Downy and the Hairy Woodpecker excavate holes during the fall in which they pass the winter nights.

Picoides arcticus (Swainson). Arctic Three-toed Woodpecker.

Merriam ${ }^{1}$ records that a specimen was taken at Simsbury in I860 (in Shurtleff coll., Wesleyan University Museum), and that Dr. Wood had taken it at East Windsor Hill. These are the only Connecticut records.

Sphyrapicus varius varius (Linnæus). Yellow-bellied Sapsucker.

A tolerably common spring and fall migrant in April, October, and November; rarely wintering.

${ }^{1}$ Merriam, Birds of Conn., p. 64. 
Spring migration. Earliest record. New Haven, April 2, I888; Portland, April 9, I875. Latest record. New Haven, April 27, I900; Portland, April 23, 1902.

Fall migration. Earliest record. New Haven, Sept. 28, I898, Sept. I6, I887 (H. W. F.) ; Portland, Sept. I7, I894. Latest record. New Haven, Dec. 2, I882; Portland, Oct. 25, I896.

Winter records. Dec. I7, I88I, New Haven, young female taken (L. B. B.) ; Feb. 1o, 1899, New Haven, one taken (Osborne and Austin).

Summer records. May ıo, I887, Portland (J. H. S.) ; May 6, 1893, Fairfield (Eames, in coll. of Beers).

Breeding record. H. K. J. reports ${ }^{1}$ that Mr. Williams has in his possession two sets of eggs found in two nests in Winsted about 1893 .

Phlœotomus pileatus abieticola (Bangs). Northern Pileated Woodpecker.

A rare winter and spring visitant; very rarely breeding.

Connecticut records. Linsley reported it from Stratford and New Haven ;2. W. W. C. noted one killed in Portland in Novem-

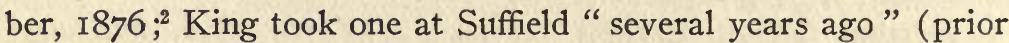
to 1877$) ;$; spring, I879, Stamford, two seen and plainly identified (Hoyt) ; Nov. I, I890, Granby, one taken by Welch (J. H. S.) ; May Io, I894, Neversink Swamp, Danbury, one seen (Hamlin); winter, 1894-5, Granby, one seen (Welch) ; Dec., I900, Cornwall, one seen; June I3, 1903, New Hartford, one shot by Sweetland (in coll. of J. H. S.).

Breeding records. May 30, I90I, Torrington, nest with one young found 20 feet from the ground in a pine tree in a very large cavity (Hanson); $\mathrm{Mr}$. Williams found nests of this species a dozen years ago (1896) in the vicinity of Litchfield. ${ }^{5}$

Melanerpes erythrocephalus (Linnæus). Red-headed Woodpecker.

A rare fall migrant; a very rare spring migrant and summer resident; an irregular winter resident; formerly an abundant resident.

${ }^{3}$ H. K. Job, The Sport of Bird Study, p. 299.

2 Merriam, Birds of Conn., p. 64.

Auk, x, 4, p. 371.

- Auk, xviii, 2, p. 193.

- H. K. Job, The Sport of Bird Study, p. 300. 
Old records. Dr. Wood of East Windsor Hill recorded ${ }^{1}$ in I88I that "forty years ago they were about as common as the Yellow-hammer [Flicker] in this part of the state. They entirely disappeared in 1847 , and I did not see another specimen until r86o." Prof. Silliman informed Prof. A. E. Verrill in 1864 that these birds were abundant residents near New Haven as late as 1840 . Linsley gave it from Stratford, and Merriam ${ }^{2}$ recorded it as rare in $I 877$, noting also that it was rare in the vicinity of Portland (W. W. C. and J. H. S.). Hence this bird may be considered abundant until the forties, since which time it has become increasingly rare.

Fall records. Most of the recent records of this species in Connecticut are for the fall (late September and early October), when the Red-headed Woodpecker is occasionally noted accompanying the Flickers in their fall migration. New Haven, abundant between Oct., I88I, and March, I882 (L. B. B.) ; also, I2 records by L. B. B., 3 by L. B. W., 2 by Webb, I by A. H. V. Portland, 9 fall records by J. H. S. Litchfield, 3 records by E. S. W., I by L. B. W. Stamford, 3 records by Hoyt. Bridgeport, 2 records by Beers and Eames.

Breeding records. Prior to 1863 , East Windsor Hill, two eggs collected by Dr. Wood (in Peabody Museum); prior to I880, Guilford, one egg taken (in coll. of L. B. B.) ; May 20, 1882, Portland, five eggs (J. H. S.) ; 1893, New Haven, nest with young (Hedges); May Io, 1898, New Haven, pair seen by A. H. V. and L. B. B.; June 23, 1906, Litchfield, set of four eggs (E. S. W.) ; brood of young seen about July, I909, New Haven (A. A. S.).

Other spring records. Portland, May I5, I883 (J. H. S.) ; New Haven, May 19, 24, 25, 1883 (L. B. B.) ; May 22, 1886, March 7, I887, May 10, I888 (Webb); May 20, I902, May 19, 1907 (A. A. S.) ; spring of 1908, birds seen and nest found (N. H. Bird Club).

Summer records. July 3,1876 , June 3,1898 , Portland ( $\mathrm{J}$. H. S.) ; summer of 1882 rather common, June 29,1884 , New Haven (L. B. B.).

10. and 0. , vi, 10, pp. 78-9.

2 Merriam, Birds of Conn., p. 65 . 
Winter records. Dec. 31, I872, Dec. 3, I88I, Dec. 30, I895, Dec. 2I, I9I0, Portland (J. H. S.) ; Dec. I3, I883, New Haven (L. B. B.).

Centurus carolinus (Linnæus). Red-bellied Woodpecker. The following are the only Connecticut records: Linsley saw one " ascending an apple tree on the I6th of October, I842 " ${ }^{1} \mathrm{Dr}$. Crary informed Merriam ${ }^{2}$ that he had killed it near Hartford, and E. I. Shores that he had taken a female, July 30, I874, at Suffield. In the Linsley collection of the Bpt. Sci. Soc. is a mounted bird of this species collected by Sidney Mather, but it may not have been taken in Connecticut.

Colaptes auratus luteus Bangs. Northern Flicker. ${ }^{3}$

A common summer resident from April to October, the majority passing through the state as migrants; a few winter regularly.

Earliest record. New Haven, March I8,.I882; 4 Portland, March Io, I898.

Latest record. New Haven, Nov. Io, I903; Portland, Nov. 3, 1908 .

Winter records. New Haven, Dec., I882, 83, 96; Jan., I882, $83,86,94,95,98$, I901, 02, 03, Feb., 1883, 1904, 1912 (L. B. B.) ; Jan., I884 (L. C. S.) ; Portland, Dec., I885, I908, Jan., I898, I909, I I, I2, Feb., I9Io (J. H. S.).

Fall flight. Large numbers of these birds fly westward along the coast late in September in the fall migration, flying early in the morning and alighting on the dead tops of trees. The mornings on which these birds are most abundant are similar in temperature conditions to those formerly known as "pigeon mornings"- clear, cool mornings following a sudden drop in temperature; and, until the law protecting these birds put a stop to the practice, "Yellow-hammer shooting" filled the gap left by the extermination of the Passenger Pigeon. Poles were fastened on the tops of tall and isolated trees, and the hunter waited below, hidden under a screen of boughs, and shot the Flickers as they

1 Am. Jour. Sci. and Arts, [r] xliv, p. 263; recorded also by Merriam.

'Merriam, Birds of Conn., p. 65.

'Known also as the Yellow-hammer, Golden-winged Woodpecker, Highhole, and Pigeon Woodpecker. Called "Woodquoi" in Portland.

4 Migrants. 
alighted on this pole. Recently large numbers of these birds, sometimes as many as several hundred in the course of an hour in the early morning, flying rapidly westward, have been seen by L. B. B. near New Haven, Sept. 28, I898, Sept. 25, I900, Sept. 29, 30, 1903, Sept. 22, 1904.

Nest. A hollow excavated by the bird, or a natural cavity in a tree, at from 5 to 30 feet from the ground.

Eggs. 5-10, commonly 7 or 8; latter part of May.

Nesting dates. Earliest record. May 9, 1896, five eggs (J. H. S.). Latest record. June 19, 1872, seven eggs (J. H. S.); July I2, I88I, six young (L. B. B.).

L. B. B. found a nest, June 6, I882, containing in eggs and 2 young; but, as one-half the eggs were perfectly fresh, the cavity was doubtless occupied by two females; one taken by C. W. W., May 21, 1888, contained to eggs.

Forty-eight holes made by woodpeckers were counted on one side of a large dead stump in the woods at Guilford by L. B. B., March I4, I885, about twenty of them having been made by this species.

A. H. V. shot a Flicker with the upper mandible so deformed as to be useless for working on wood, Sept. 28, 1897; and L. B. B., one with the feet and head so badly infected with some kind of fungous disease that one eye was entirely closed, Oct. I6, I906; both are in coll. of L. B. B.

\section{Order MACROCHIRES. Goatsuckers, Swifts, etc.}

Suborder CAPRIMULGI. Goatsuckers, etc.

Family CAPRIMULGID压. Goatsuckers, etc.

Antrostomus carolinensis (Gmelin). Chuck-will's-widow.

A mounted specimen in the Peabody Museum was caught alive by Mr. Decatur Morgan in New Haven, May 17, 1889.

This bird has been recorded also by Mr. A. H. Verrill. ${ }^{1}$

Antrostomus vociferus vociferus (Wilson). Whip-poorwill.

A common summer resident of woodland from May to August.

1O. and O., xiv, 6, p. 96. 
Earliest record. New Haven, April 22, I893; Portland, April 23, 1886.

Latest record. New Haven, Sept. 17, 1900; Portland, Sept. 21, 1893.

Nest. Eggs deposited on a few dead leaves on the ground, usually not far from the border of the woods.

Eggs. 2; the last of May.

Nesting dates. Earliest record. May 18, I893, two eggs ( $\mathrm{J}$. H. S.). Latest record. July 4, 1884, two eggs (H. W. F.).

Late fall records. Nov. I, I880, Noank (C. L. R.) ; Oct. 5, 1901, Westville (G. V. Smith, in coll. of L. B. B.).

Chordeiles virginianus virginianus (Gmelin). Nighthawk.

Formerly an abundant summer resident of the open pastures from the middle of May to September; now rare through most of the state in the breeding season, and occurring commonly only in the fall migration.

Earliest record. New Haven, May 7, I888; Portland, April 28,1888 .

Latest record. New Haven, Oct. I7, I890; Portland, Oct. Io, 1902.

Nest. Eggs laid on a rock, or on a bare place on the ground in a pasture; rarely on the flat roofs of houses in the cities.

Eggs. 2, rarely $\mathrm{I}$; early in June.

Nesting dates. Earliest record. May 26, I896, two eggs $(\mathrm{H}$. W. B.) ; May 26, 1900, twa eggs (H. W. F.). Latest record. July I, I898, two eggs (J. H. H.).

Recent breeding records. Although this bird is reported as still tolerably common in the vicinity of Stamford both by Hoyt and Porter, throughout most of the state it is only a rare summer resident. The last pair seen near New Haven by L. B. B. was on May 15, 1900, this pair having left the open fields where they have been so persecuted, and taken refuge in a small opening in the woodland. The last nest recorded by J. H. S. from the vicinity of Portland is one found June 6, 1894 .

A remarkable migration of these birds was witnessed by L. B. B. near Sachem's Head, Guilford, early in September, I880 (?), late in the afternoon. Large numbers of these birds, collected 
in a broad band that extended from horizon to horizon, were watched flying westerly not far from the coast for about a quarter of an hour; the number of birds still passing showing little diminution when he was obliged to leave.

\section{Suborder CYPSELI. Swifts.}

Family MICROPODID瓜. Swifts.

Subfamily Chжturinж. Spine-tailed Swifts.

Chætura pelagica (Linnæus). Chimney Swift. An abundant summer resident from May until September. Earliest record. New Haven, April 19, I884, April I4, I876 (Osborne) ;' Portland, April 18, 1896.

Latest record. New Haven, Oct. 29, I888; Portland, Oct. I I, 1877.

Unusual record. New Haven, Nov. 7, 1907, one found dead after a heavy storm (L. B. B.).

Nest. In a chimney.

Eggs. 3 to 5 ; latter part of June.

Nesting dates. Earliest record. June 4, I897, five eggs (J. H. H.). Latest record. July 4, I890, three eggs (H. W. B.).

In the latter part of the summer these birds often collect in large flocks, sometimes three or four hundred strong, and spend the night together in some commodious chimney. Flying over this chimney in a broad circle toward dark, some of them are constantly dropping into it until all have disappeared for the night. One such roosting chimney was found in Portland by J. H. S. in 1877 , and another in Guilford by L. B. B. in 1884 .

Suborder TROCHILI. Hummingbirds.

Family TROCHILID E. Hummingbirds.

Archilochus colubris (Linnæus). Ruby-throated Hummingbird.

A tolerably common summer resident from the middle of May until August, but apparently not as common as formerly.

Earliest record. New Haven, May 4, 1882; Portland, May 5, 1905 . 
Latest record. New Haven, Sept. 29, I882, Oct. I6, I874 (Merriam); Portland, Oct. 2, 1905.

Unusual record. March I, I902, Saybrook, a female beat itself against the panes in a window in the house of J. N. C., trying to reach some flowers inside.

Nest. Usually made of lichens or material closely resembling the bark of the tree on which it is located; as a rule from 9 to I2 feet from the ground, in orchard or garden, in the woods or in the shade trees of the city streets.

Eggs. 2 (invariably); early in June.

Nesting dates. Earliest record. May I3, I89I, two eggs (H. W. B.). Latest record. Aug. 4, I88I, two eggs (Smith) ;2 Aug. 14, I9Io, two eggs (C. G. H.).

\section{Order PASSERES. Perching Birds.}

Suborder ClamatoRes. Songless Perching Birds.

Family TYRANNIDÆ. Tyrant Flycatchers.

Muscivora forficata (Gmelin). Scissor-tailed Flycatcher.

The only record of this species is a specimen shot, April 27, I876, at Wauregan, by Mr. Carpenter. "The bird first attracted Mr. Carpenter's attention by its opening and closing the tail while flying about a small sheet of water in quest of insects." 3

Tyrannus tyrannus (Linnæus). Kingbird.

A common summer resident, arriving during the first two weeks in May, and going south in August.

Earliest record. New Haven, May I, I896, April I3, I877 (Dayan) ; Portland, April 28, I88I. Thirty-five out of thirtynine years' records for Portland were between May I and May I4 (J. H. S.).

Latest record. New Haven, Sept. I5, I902; Portland, Sept. Io, 1887 .

Nest. Usually on the topmost branch of an apple tree at from 12 to 25 feet from the ground.

Eggs. $2-6$, usually 2 or 3 ; early in June.

2 Merriam, Birds of Conn., p. 62.

$O$. and $O$., vi, 7, p. 53 .

3 Bull. Nuttall Ornith. Club, ii, r, p. 21; recorded also by Merriam, Birds of Conn., p. 50.

4 Merriam, Birds of Conn., p. 49. 
Nesting dates. Earliest record. May 29, 1898, four eggs (J. H. H.). Latest record. July 4, I882, four eggs (L. B. B.). Unusual sets. June 3 , I894, Branford, nest with six eggs found (Nichols) ; July 6 , I882, New Haven, nest with six young (L. B. B.).

Albinos. Aug., I880, Laurel Hill, near Norwich, an albino Kingbird found the body pure white, wings and tail a light cream color (no date given). ${ }^{1}$ Aug., I890 (?), Woodbridge, a remarkable albino taken; its bill, tarsi, toes, nails, and the entire plumage being pure white, except that the wings and tail were tinged with sulphur yellow. The eyes were deep pink. (In possession of J. M. Blake, New Haven.)

Myiarchus crinitus (Linnæus). Crested Flycatcher.

A tolerably common summer resident of orchards and woodland from the middle of May until August. In Litchfield it is rare (E. S. W.).

Earliest record. New Haven, May I, I906; Portland, May $4,1896$.

Latest record. New Haven, Sept. 18, I903.

Nest. An old woodpecker's hole or other cavity, usually from 7 to 15 feet from the ground; in an apple tree.

Eggs. 3-6; early in June.

Nesting dates. Earliest record. May 27, I896, six eggs (L. B. B.). Latest record. June 18 , I892, five eggs (J. C. A. M.). Unusual record. May 27, I889, Northford, set of seven eggs (A. M. Linsley). ${ }^{2}$

A nest of this species was once found by Mr. W. R. Nichols built somewhat like that of a Kingbird on the branch of a tree. This is very unusual, as this species practically always occupies a cavity in a tree.

Sayornis phœbe (Latham). Phœbe.

A common summer resident, arriving the last of March and remaining until October.

Earliest record. New Haven, March 20, I894, March 14, 1902 (A. A. S.), Feb. 25, I876 (Hall) ;3 Portland, March I8,

10 . and $O ., \mathrm{v}, 6, \mathrm{p} .47$.

2 Oölogist, vi, 12, p. 233.

9 Merriam, Birds of Conn., p. 52. 
I898, I907; Hartford, March 13, I898; Jewett City, March I5, 1902. ${ }^{1}$

Latest record. New Haven, Oct. 18, 1904, Oct. 26, 1906 (E. S. W.) ; Portland, Oct. I4, I89r, I893.

Winter records. New Haven, Dec. 25, 1909 (D. B. P., C. H. P., and A. W. H.) ; one seen, Dec. 21, 1905-March 1o, 1906, and Nov. 25, 1906 - Jan. 22, 1907 (A. A. S.).

Nest. On the pillar of a porch, the rafter of a shed, inside an abandoned house, in the cellar of a barn, under a bridge, on a ledge of rocks, under the overhanging edge of a bank, or in the upturned roots of a tree; nest of mud and moss, lined with horse-hair.

Eggs. 3-6; early in May.

Nesting dates. Earliest record. April 27, 1898, five eggs (L. B. B.). Latest record. July Io, I882, six eggs (C. L. R.). ${ }^{2}$

Nests are occasionally placed in abandoned nests of the Barn Swallow, while one containing five eggs was found placed in an old Robin's nest on a girder in a barn, May ${ }^{5}$, 1893, in Trumbull (Beers).

An unusual nesting site was noted by W. W. C., Portland, on "a brace under the guards of the steam ferry-boat running [at that time] between Middletown and Portland."3 This nest was seen by J. H. S.

Nuttallornis borealis (Swainson). Olive-sided Flycatcher.

A rare spring and fall migrant in late May and September.

Spring records. May 24, I892, New Haven, male taken (Hedges, in coll. of L. B. B.) ; May 24, 1893, New Haven, female taken (A. H. V.) ; May 23, I900, May 23, I902, and May I9, 1909, New Haven, two taken, another seen (L. B. B.).

Fall records. Aug. 5, 1874, Suffield, male taken (Shores) ; Oct. 18, 1875, New Haven, one seen (Merriam) ;4 Aug. 27, 1903, Danbury, young female taken, and pair with three young seen several times during summer of 1903 (Hamlin); Sept. 13, 1904, New Haven, young female taken (L. B. B.) ; Aug. 31, 1904,

1 Bird-Lore, x, 5, p. 2 Io.

2O. and $O$., xvii, 5, pp. 77-8.

$O$. and $O$., vii, 23, p. 183 .

- Merriam, Birds of Conn., p. 53. 
Sept. 8, 1906, New Haven, seen (L. B. B.) ; Sept. 15, 1905, Litchfield, one taken (E. S. W.).

Myiochanes virens (Linnæus). Wood Pewee.

A common summer resident of woodlands and shade trees from the latter part of May until late in August.

Earliest record. New Haven, May Io, I899; Portland, May 6, 1879,1905 .

Latest record. New Haven, Sept. 30, 1903; Portland, Oct. 3,1890 .

Nest. In an orchard, a shade tree (frequently an elm), or in the woods, about ro to 20 feet from the ground.

Eggs. 2-4; the latter part of June.

Nesting dates. Earliest record. June 8, 1884, one egg (E. H. E.). Latest record. July I2, 1903, three eggs (J. C. A. M.).

Flying young were seen by J. H. S. and L. B. B. in Salisbury on the unusually early date of June 16,1904 .

Sets of three eggs each on the same fork of the same limb of a certain tree were found by J. C. A. M., June I6, I895, June I3, 1897 , and June 19, I898, with no nest there in 1896 , and all three sets very different in their markings.

Empidonax flaviventris (W. M. and S. F. Baird). Yellowbellied Flycatcher.

A rather rare spring and fall migrant in May, August and September, keeping in secluded nooks in young woodland as it passes through the state.

Spring migration. Earliest record. New Haven, May 16, 1888, 1900. Latest record, May 28, 1909.

Fall migration. Earliest record. New Haven, Aug. 15, 1907. Latest record, New Haven, Sept. I, I896, I906; Sept. I7, 1875 (Merriam). ${ }^{1}$

At Stamford in late summer this bird is occasionally common, as Mr. Porter secured ten males between Aug. I7 and Sept 26, 1893. $^{2}$ Hoyt took one at Stamford, May 17, 1890, and L. B. B., one, May 25, 1905; Eames, at Stratford, May 7, 1892, and at Bridgeport, May 27, I892; W. E. T., one at East Hartford, Sept. 20, 1887, and three, May 23, 1892 (in coll. of J. H. S.).

1 Merriam, Birds of Conn., p. 59.

2Auk, xii, I, p. 86. 
Empidonax virescens (Vieillot). Acadian Flycatcher.

A rare summer resident of the southern border of the state; most common west of Stamford.

Earliest record. Stamford, May 17, I890 (Hoyt).

Latest record. Stamford, Sept. I9, 1893 (Porter).

Spring records. June 24, I874, Suffield, one taken (Shores) ;1 May 17, 1890, Stamford, male taken (Hoyt, in coll. of L. B. B.) ; June 13; r891, New Haven, male taken (Hedges, in coll. of L. B. B.) ; June 3, I896, Guilford, male taken (L. B. B.).

Breeding records. Spring, 1875, Stamford, nest with five eggs (Hoyt) ; June 25, 1893, Greenwich, nest with three young (Voorhees);2 June 2, I894, Stamford, nest with three eggs (Rowell) ; May 20, I903, Danbury, one pair, believed to be breeding, collected (Hamlin); June 2, 1906, Stamford, two nests with three eggs each, two other pairs of breeding birds, six old nests, found (Porter). ${ }^{3}$ Mr. Porter describes the nests as always loosely thrown together with shreds hanging down from the sides; made of hemlock bark or grass.

Empidonax trailli alnorum Brewster. Alder Flycatcher.

A rare late spring and late summer migrant; regular summer resident in northwestern part of the state.

Spring migration. Earliest record. New Haven, May 26, 1909; Litchfield, May 27, 1905 (E. S. W.). Latest record. New Haven, May 31, I904.

Fall migration. Earliest record. New Haven, Aug. 9, I904. Latest record. New Haven, Sept. 7, 1905; Litchfield, Sept. 28, 1900 (E. S. W.).

Breeding records. June 22, I886, Litchfield, nest with three well incubated eggs (L. B. W.) ; June 12, 1900, Warren, unfinished nest found, and a female, which would have laid in a few days, taken (A. H. V. and L. B. B.) ; June I3, 1905, Litchfield, three nests found, containing two sets of four eggs each and one of three eggs, nests in alders and a spruce, between $I$ and 2 feet from the ground (E. S. W.) ; June 18, 1906, Litchfield, nest with four eggs (E. S. W.).

1 Merriam, Birds of Conn., p. 58.

$2 A$ uk, xi, 3, p. 259.

3 Auk, xxiv, I, p. 99 . 
Empidonax minimus (W. M. and S. F. Baird). Least Flycatcher.

A common summer resident of the orchards and shade trees of the state from early May to August.

Earliest record. New Haven, April 27, I885; Portland, April 2I, I880; Hadlyme, April 26, I899; ${ }^{1}$ Hartford, April 27, I902. ${ }^{1}$

Latest record. New Haven, Sept. Io, I883, Oct. I, I907 (A. A. S.) ; Portland, Sept. 4, I893; Litchfield, Oct. I, I890 (L. B. W.).

Nest. Of the 25 nests recorded in the last 5 years by J. H. S., 7 were in elms, 6 in willows, 6 in ash trees, 3 in wild cherries, and 3 in poplars; height from ground, $15-30$ feet, except one at 5 feet and another at 40 feet; location, commonly an open swampy place, occasionally in thick growth. Building, May I5-June 8.

Eggs. 3-5; early in June.

Nesting dates. Earliest record. May 23, 1906, two eggs (same nest, four eggs, May 26) (J. H. S.). Latest record. June 27, I888, five eggs (E. H. E.).

\section{Suborder Oscines. Song Birds.}

Family ALAUDID压. Larks.

Otocoris alpestris alpestris (Linnæus). Horned Lark.

An irregular winter visitor from November to March; most common in small flocks along the coast.

Earliest record. New Haven, Nov. 2, I906, Oct. 29, I888 (L. B. W.).

Latest record. New Haven, April I5, 1882.

Inland records. March 22, I875, Portland, two killed (one in coll. of C. H. N.) ; Dec. 3, I889, East Hartford, two seen (W. E. T.) ; March 25, I890, Portland, flock of thirteen seen (C. H. N.) ; March 27, I899, about thirty seen, March 30, I899, about twelve seen, Portland (S. R., one in coll. of J. H. S.) ; Oct. 27, I903, Nov. I4, I904, Litchfield, small flocks seen (E. S. W.).

A bird in which one tarsus had been broken and the foot had become fastened in the feathers of the abdomen was taken by L. B. B. in Guilford, Feb. I I, 1898. 
Otocaris alpestris praticola Henshaw. Prairie Horned Lark.

A rare winter resident in the state; breeding in Litchfield County.

Winter records. Feb. I, 1889, Guilford, one female taken (L. B. B.) ; middle of Sept. to Oct. 10, 1900, Litchfield, a small flock seen, and specimens collected Oct. 7, 8 (L. B. W.); Feb. 6, 1904, Westville, small flock, one shot (Smith, in coll. of L. B. B.) ; Nov. II, I905, West Haven, flock of three taken (E. S. W. and L. B. B.) ; Jan. 3, I910, West Haven, female taken (D. B. Pangburn, in coll, of L. B. B.).

Summer records. June 20, 1904, Salisbury, seen flying (J. H. S. and L. B. B.) ; July 3I-Aug. 4, I905, Goshen; April 22, June 2, July 8, 1906, Litchfield (E. S. W. and H. Sanford).

Breeding records. May 24, I891, Torrington, set of four eggs with the female taken (Gath) ;1 1904, Watertown, pair breeding (Dutcher); $;^{1}$ May 25, 1905, Litchfield, pair breeding (E. S. W.) ;2 March 26, I908, Danbury, nest with four eggs, hatched March 27 (Judd). ${ }^{3}$

Nest of this species thus described by Judd: ${ }^{3}$ "A neat, wellmade structure of fine, soft dead grass was placed in a hollow caused by the removal of a small stone on the gravelly western slope of a large round-topped sand hill."

Otocoris alpestris hoyti Bishop. Hoyt's Horned Lark.

A very rare accidental visitor.

Connecticut records. March 4, 1893 , Bridgeport, one male and one female taken, somewhat nearer this form than a true alpestris (Eames, in coll. of Beers); Feb. 17, 1894, Stamford, male (Porter); March 7, 1903, Guilford, a male taken along with two typical alpestris males from a flock of Horned Larks (L. B. B.) ; Jan. 24, 1905, West Haven, male taken (A. Ganung, in coll. of L. B. B.); Nov. 3, 10, 1906, Guilford, two taken (E. S. W.).

${ }^{1} \mathrm{H}$. K. Job, The Sport of Bird Study, p. $30 \mathrm{r}$.

$2 A u k$, xxiii, 4 , p. $46 \mathrm{r}$.

8 Bird-Lore, X, 3, pp. 129, 130. 
Family CORVID E. Crows, Jays, Magpies, etc.

Subfamily Garrulinæ. Magpies and Jays.

Cyanocitta cristata cristata (Linnæus). Blue Jay.

A common summer resident, a few wintering regularly; the majority going south early in October when there is a regular western flight, and returning in April.

Earliest record. New Haven, March 25, I893; 1 Portland, Feb. 8, 1896, Feb. 12, 1900, 06, 07, 08.

Latest record. New Haven, Nov. 30, I901; Portland, Nov. 27, 1889 .

Winter records. New Haven, Jan., I882, 83, 84, 85, I894, 95, 96, 98, 1900, о1, о2, о5 ; Dec., 1882, 83, 84, 1893, 95, 96, 1900, 03, 04, 05; Portland, Jan., I88ı, Dec., I88I, 85, 87 .

Nest. In a conifer or deciduous tree, usually near the border of dense brush or woodland; height from ground, $5^{-1} 5$ feet.

Eggs. 3-6; early in May.

Nesting dates. Earliest record. April 25, 1900, three eggs (L. B. B.). Latest record. July I, I882, six eggs (L. B. W.). Migrating flocks observed near New Haven, April I, 1896, Oct. 3, I882, Sept. 30, I890, Sept. 29, I897, Sept. 29, 30, I903 (L. B. B.).

\section{Subfamily Convine. Crows.}

Corvus corax principalis Ridgway. Northern Raven.

Very rare.

Connecticut records. Dec. 28, I889, West Haven, a bird, from its size, flight, and the marked emargination of its primaries, believed by L. B. B. to be a Raven, flew by him, about 125 yards away and roo feet from the ground. As it uttered no sound, its identity is doubtful. Sept. 18 , 1890, South Manchester, "a specimen of the American Raven was taken at this place" (O. J. Hagenaw). ${ }^{2}$

Corvus brachyrhynchos brachyrhynchos Brehm. Crow. An abundant resident, gathering in flocks along the seashore in winter, but many going farther south in October. 
A regular migration westward occurs near the coast late in October, as has often been witnessed by L. B. B. and many others.

Roost. In the early eighties there was a larger winter roost in a pine grove in Hamden, containing probably 10,000 birds on the night of Feb. 22,1882 (L. B. B.).

Nest. Large nest of sticks, dry weeds, etc., often lined with grapevine bark, usually close to the trunk of a chestnut or conifer, or in the top of a poplar, birch, or other tree; 12 to 80 feet from the ground.

Eggs. $4-7$, commonly 4 or 5 ; middle of April.

Nesting dates. Earliest record. April Io, I882, three eggs (L. B. B.). Latest record. June I2, I892, four eggs (J. C. A. M.).

Unusual eggs. Six pinkish eggs were found in a nest near New Haven, May 8, I884 (two in coll. of L. B. B.) ; light blue, almost unspotted eggs also occur in nests in which the other eggs are normal; a single egg in a set of six found measuring only I.20 by .87 inch, May I8, I893, Stratford (J. C. A. M.) ; a set of four pinkish eggs is in the Wood collection at the Morgan Memorial, Hartford, taken at South Windsor (J. H. S.).

A set of seven eggs was collected in the spring of 1893 near New Haven (H. W. F.).

L. B. B. records a Crow found in New Haven, Sept. I, I906, with a peculiar hoarse voice, which upon examination was learned to be due to a profuse purulent rhinitis.

A cinnamon colored Crow is recorded from Groton, Aug. 20, I879. ${ }^{1}$

Corvus ossifragus Wilson. Fish Crow.

A rather rare resident near the coast, and extending some distance up the larger rivers.

Distribution. Small colonies and isolated nests have been found. near the shore of the Sound at Woodmont, Milford, and Stratford (J. C. A. M.) ; at Niantic (Hill); New Haven (L. B. B. and C. C. T.) ; Fairfield and vicinity (Eames) ; $^{2}$ various points in Fairfield County (Beers); along the Housatonic Valley, as far north as Gaylordsville (Eames); along the Connecticut River 
(Canfield and Watrous). One was taken in North Haven, Feb. 20, 1902, by Mr. Harry Ludington (in coll. of L. B. B.).

Nest. Usually located in the small branches at the top of the tallest tree in the vicinity, at a height of $35-60$ feet from the ground; the birds breed in single pairs or in small colonies, near the coast.

Eggs. 3-5; early in May.

Nesting dates. Earliest record. May 5, 1895, five eggs (J. C. A. M.). Latest record. June 3, I894, two eggs (J. C. A. M.). Breeding records. May, I888, New Haven, three eggs (C. C. T.) ; May I2, 16, I89I, Fairfield, four and five eggs respectively (Eames) ;1 June 3, 1894, two eggs (J. C. A. M.) ; May 5, 1895, five eggs (J. C. A. M.); May 4, I900, four eggs, and May 19, 1906, five eggs (Beers); May I2, 1901, Niantic, colony with five, five, four, and three eggs, and four young (Hill); May I4, I904, four eggs, May 21, 1904, four young, and May 10, 1905, two sets of five eggs (L. B. B.).

Family ICTERIDÆ. Blackbirds, Orioles, etc.

Dolichonyx oryzivorus (Linnæus). Bobolink.

A common but decreasing summer resident from the last of May until August, most abundant in the northern part of the state.

Earliest record. New Haven, May 5, 1898; Portland, April 27, I89r. The usual arrival is between May 5 and 15 (average of 44 years' records, J. H. S.).

Latest record. New Haven, Sept. 25, I895; Portland, Oct. 15 , 1890.

Nest. Eggs deposited on the ground in a meadow.

Eggs. 4-6; early in June.

Nesting dates. Earliest record. May 25, 1897, six eggs ( $\mathrm{H}$. R. Buck). Latest record. June 20, 1887, four eggs (H. W. F.).

In the southern part of the state the Bobolink now breeds commonly only in the meadows bordering the larger salt marshes, as at Stratford and Hammonasset Point.

Mr. Buttrick notes ${ }^{1}$ that, from observations of this species made at Woodmont, he believes the Bobolink is at times polygamous; also that the young leave the nest before they are able to fly, when they are cared for by the females. 
Molothrus ater ater (Boddaert). Cowbird.

A common summer resident from April to November; occasionally lingers to January and probably winters.

Earliest record. New Haven, March I9, I90I ; Feb. 20, I887 (L. B. W.) ; Portland, March 21, I9Io.

Latest record. New Haven, Dec. I, 1903; Portland, Oct. 22, 1877.

Winter records. Jan. I5, I874, Jan. I6, I875 (Grinnell) ; Feb., I886, Woodbridge (Augur); Jan. I I, I887, East Hartford (W. E. T.) ; Jan. I7, I889, Bridgeport (Eames) ; Dec. II, I894, Dec. I3, I895, Portland (J. H. S.) ; Dec. 25, I901, Jan. Io, I902, North Haven (Ludington, in coll. of L. B. B.) ; Dec. 26, I904, Stratford (H. W. B. and J. C. A. M.).

Nest. The Cowbird does not build a nest, but deposits its egg or eggs in the nest of another and usually. smaller species, the Red-eyed Vireo, Yellow Warbler, and Oven-bird being most frequently selected.

The following table shows the distribution of the eggs as recorded by J. H. S. and L. B. B. in II9 nests examined. The numbers in the three columns are the numbers of nests of the species named containing, respectively, one, two, and three eggs of the Cowbird.

$\begin{array}{lrl}\text { Red-eyed Vireo } & \text { I6 } & 4 \\ \text { Yellow Warbler } & \text { I6 } & \text { I } \\ \text { Oven-bird } & \text { I I } & 2 \\ \text { Wilson's Thrush } & 7 & \\ \text { Redstart } & 6 & \text { I } \\ \text { Indigo Bunting } & 5 & \text { I } \\ \text { Field Sparrow } & 5 & \\ \text { Phœbe } & 3 & \text { I } \\ \text { Maryland Yellow-throat } & 3 & \text { I } \\ \text { Song Sparrow } & 3 & 2 \\ \text { Yellow-throated Vireo } & 3 & \\ \text { Chestnut-sided Warbler } & 3 & \\ \text { Prairie Warbler } & 3 & \\ \text { Purple Finch } & 2 & \\ \text { Scarlet Tanager } & 2 & \end{array}$


Wood Thrush 2

Blue-winged Warbler 2

Louisiana Water-Thrush I I

Yellow-breasted Chat I I

One Cowbird's egg was found in one nest of each of the following species, viz., Orchard Oriole, Chipping Sparrow, Cedar Waxwing, White-eyed Vireo, Worm-eating Warbler, Black and White Warbler, Wood Pewee, and Brown Thrasher.

Other species recorded are Robin (J. C. A. M.), Towhee (J. C. A. M. and Beers), Bobolink (L. B. W.), Bluebird (A. A. S.).

Eggs. I-3, per nest; about the last of May or early in June.

Dates. Earliest record. May I I, 1904, April 29, 1906, one in Phœbe's nest (A. A. S.). Latest record. Aug. 4, 1882, two in Red-eyed Vireo's nest (L. B. B.).

There can be little doubt that the Cowbird often injures and sometimes removes one or more of the eggs of the host. Frequently the rightful egg has been found (L. B. B.) to be pierced with small holes, and at least twice one lying on the ground outside the nest. On the average a nest containing an egg of this parasite will be found to contain one less egg of the species owning the nest than is normal to that bird.

Occasionally, as is well known, some of our smaller birds will build a false bottom to the nest covering the intruding egg, and lay their own above it. In a nest of the Yellow Warbler and one of the Chestnut-sided Warbler, each containing four eggs and an egg of the Cowbird buried in the bottom, found by J. C. A. M., it is certain that the Cowbird's egg was the first laid, as in each instance he had visited these nests a week earlier and had found the Cowbird's egg alone in each.

Although remaining in flocks practically all the year, Cowbirds seem to separate into pairs for a short time in the spring. At this time a single male may often be seen seated in some treetop, calling, while probably the female is looking for a nest in which to lay.

Xanthocephalus xanthocephalus (Bonaparte). Yellowheaded Blackbird.

Accidental. 
Connecticut records. 1878 (?), New Haven (?), a female formerly in the collection of Dr. W. H. Hotchkiss and now in the collection of L. B. B. (without label, but Dr. H. informed L. B. B. that all of these birds were taken near New Haven, chiefly during the spring of I878); July, I884, Hartford, one in a flock of Red-wings shot (W. E. T.) ;1 July, 1888, Stamford, female shot (E. K. Colbron). ${ }^{2}$

Agelaius phœniceus phœniceus (Linnæus). Red-winged Blackbird.

An abundant summer resident, occasionally wintering; the males arriving on the average more than a month in advance of the females.

Males. Average date of arrival, March 5-20. Earliest record. New Haven, Feb. Io, I896, Feb. I9, I887 (Hooker), Feb. 20, 1887 (L. B. W.) ; Portland, Feb. 26, 1906.

Females. Average date of arrival, May I-Io. Earliest record. New Haven, April I3, I887; Portland, April 26, 1910.

Latest record. New Haven, Dec. 7, 1893; Portland, Nov. 23, 1906.

Winter Records. Jan. I5, I874, Jan. I6, I875 (Grinnell) ; Dec. 28, 1882, Dec. 27, 1883, Guilford, small flocks (L. B. B.) ; Dec. 25, I901, Jan. IO, I902, North Haven, several collected (Ludington, in coll. of L. B. B.) ; Jan. 7, 1905, Falls Village, one seen (H. K. J.) ; Jan. I, I9Io, New Haven, several seen, one female taken (C. H. P.).

Nest. On a tussock of marsh grass, a clump of weeds, a bunch of cat-tails, royal fern, or in a low bush (alder).

Eggs. 2-5; the last of May.

Nesting dates. Earliest record. May 16, I894, four eggs (J. C. A. M.). Latest record. July 2, 1881, three eggs (L. B. B.).

Agelaius phœniceus fortis Ridgway. Thick-billed Blackbird.

A very rare straggler from the West in the fall, occurring occasionally with the flocks of the other blackbirds in the roosts in the Quinnipiac Marshes.

$1 A u k$, iv, 3, p. 256.

$2 O$. and $O$., xiii, 12, p. 189.

3 Merriam, Birds of Conn., p. 45. 
Connecticut records. Dec. 25, I90I, one adult male, Jan. Io, I902, young male and young female, Nov. II, I903, young male, Quinnipiac Marshes, North Haven (Ludington and L. B. B., in coll. of L. B. B.).

Sturnella magna magna (Linnæus). Meadowlark.

A common summer resident of the meadows and pastures; a number winter regularly, sometimes in large flocks in the salt marshes along the coast, and scatter about the country in the last of March or early April.

Nest. Eggs laid in a tussock of grass in a field, or under a piece of drift on a salt marsh.

Eggs. 4-6; the last of May.

Nesting dates. Earliest record. May 17, 1890, three eggs (J. H. S.) ; May 19, I899, five eggs (J. H. H.) ; May 19, I904, five eggs (L. B. B.). Latest record. July 2, 1888, five eggs (Beers) ; Aug. 14, 1883, four deserted eggs (L. B. B.).

One was heard singing as laté as Oct. 22 (1892) by L. B. B.

Icterus spurius (Linnæus). Orchard Oriole.

A tolerably common summer resident along the coast from the middle of May until July, breeding as far up the Housatonic valley as Gaylordsville; breeds rarely inland, however.

Earliest record. New Haven, May 2, 1908; Portland, April 30, 1896.

Latest record. New Haven, July 30, I896; Portland, June I6, 1904.

Nest. Usually in an apple or pear tree in an orchard; height from ground, 7-15 feet.

Eggs. 4-5; early in June.

Nesting dates. Earliest record. May 29, 1896, four eggs (L. B. B.). Latest record. June 28, I904, four eggs (Perry); July 3 , I882, four young (L. B. B.).

Inland nesting records. June 2, 1885, Portland, nest with five eggs (J. H. S.) ; June Io, 1900, Gaylordsville, nest found (Austin and L. B. B.).

Unusual nesting site. Feb. 16, 1907, Portland, old nest in an elm, 40 feet from the ground (J. H. S.). 
One bird has been seen by Mr. Williams in Winchester. ${ }^{1}$ One seen in Danbury, May 4, I905 (J. C. A. M.).

Icterus galbula (Linnæus). Baltimore Oriole.

An abundant summer resident of the orchards and shade trees of the roads and city streets, from May until August.

Earliest record. New Haven, May 2, I894; Portland, April 30, I888. Average of 40 years' records, May 6 (J. H. S.).

Latest record. New Haven, Sept. 13, 1885; Portland, Sept. $8, \mathrm{I} 885$.

Winter records. Nov. 15 $_{5}$ 1885, Portland (J. H. S.) ;2 Dec. 22, I892, Portland (C. H. N.) ; North Haven, Dec. 9, I90I (found dead by Mrs. L. Hemingway).

Nest. Usually in an elm, poplar, or maple; 20-75 feet from the ground; built by the female, May 15 - June Io.

Eggs. 4-7; early in June.

Nesting dates. Earliest record. May 23, 1906, two eggs (J. H. S.) ; May 25, 1895, five eggs (H. W. F.). Latest record. June 21,1882 , one egg and three young (L. B. B.).

Abundance of species. Fifteen nests of this species were noticed in the trees bordering Quinnipiac Avenue in Montowese, in a distance of about two miles, March 3, 1893 (L. B. B.). Again, in a walk of about the same length on Whitney Avenue, New Haven, 35 nests were counted, almost all in elms, Jan. 9, I90I ; but in the same walk on Feb. I7, I908, only Io nests could be found, showing the great decrease of this species near New Haven in recent years (L. B. B.).

Euphagus carolinus (Müller). Rusty Blackbird.

A common fall migrant in October; less common spring migrant.

Spring migration. Earliest record. New Haven, March 24, 1888, March 20, 1905, 1906 (A. A. S.) ; Portland, March 20, 1905. Latest record. New Haven, April 20, 1905, May 13, I907 (C. H. Pangburn); Portland, May II, Ig08.

Fall migration. Earliest record. New Haven, Sept. 25, 1897, Sept. 15, 1897 (A. H. V.) ; Portland, Sept. 17, 1895. Latest

${ }_{1}^{1}$ Job, The Sport of Bird Study, p. 302.

$2 A u k$, iii, 1, p. 135.

3 $O$. and $O$., xviii, 3, p. 47. 
record. New Haven, Nov. 22, I900, Dec. I3, 1906 (A. A. S.), Dec. 25, I9II (C. H. P.). Portland, Nov. 3, 1908; Litchfield, Nov. 24, 1906 (H. Sanford).

Quiscalus quiscula quiscula (Linnæus). Purple Grackle.

A common summer resident of the pines and spruces about the towns and cities of the southern part of the state; breeds as far north as Bethel, Litchfield, and Portland.

Earliest record. New Haven, March 4, 1882, Feb. I9, 1902 (A. A. S.) ; Portland, Feb. 20, I880.

Latest record. New Haven, Nov. 8, I90I ; Portland, Nov. 8, 1892. These birds seem to migrate in two divisions, the first leaving between August 24 and 30, the second between Sept. 25 and Oct. 30 (J. H. S.).

Winter records ${ }^{1}$. Dec. 20, 1887, New Haven (L. B. W.); Dec. 28, I895, Hartford (J. P. Hall) ; Dec. 12, 1907, New Haven (A. A. S.).

Nest. In a conifer, from to to 40 feet from the ground.

Eggs. 3-5; May.

Nesting dates. Earliest record. April 25, I892, five eggs (J. H. S.), April 25, I895, five eggs (H. W. F.). Latest record. June 8 , I887, five eggs (Watrous).

Unusual nest. A nest in the rushes of a marsh near Kent found by $\mathrm{H}$. K. J. Very unusual, since all other nests recorded were in trees and usually at some distance from the ground.

By the latter part of June, the duties of nidification over, the birds assemble in flocks and frequent the tops of trees in the woods.

Intermediates between Quiscalus quiscula quiscula and aneus are found breeding at Portland.

Quiscalus quiscula æneus Ridgway. Bronzed Grackle.

A tolerably common summer resident in the northern part of the state, breeding in the conifers about the towns as far south as Portland. An abundant fall migrant in October and November and irregular spring migrant in the southern part of the state, and a common spring and fall migrant in the northern part.

${ }^{1}$ Probably some of these winter records refer to Quiscalus quiscula ceneus. 
Spring migration. Earliest record. New Haven, March 25, I898, Feb. 27, March Io, I906 (E. S. W.) ; Portland, March 2 I, I89I. Latest record. New Haven, April 24, I907.

Fall migration. Earliest record, New Haven, Oct. 6, I903. Latest record. New Haven, Dec. I2, I889; Portland, Nov. 3, Igo8.

Winter records. Jan. 23, I884, Hamden (Munson); Jan. I7, 1895, New Haven (L. B. B.) ; Dec. 15, I907, Jan. 22, I908, East Haven (F. F. Burr).

Summer records. July 8, I886, Plymouth, adult female (Webb, in coll. of L. B. B.) ; July 3, 1907, Litchfield, one shot (E. S. W.)

Roost. In the fall, thousands, probably tens of thousands, of blackbirds roost in the broad beds of cat-tail rushes in the Quinnipiac Marshes, about six miles north of New Haven. A1though there are hordes of Red-wings, Cowbirds, Rusty Blackbirds, and Purple Grackles in late October and early November, the Bronzed Grackles far outnumber any other if not all other species combined. The blackbirds assemble as early as Sept. 26 (I904), increasing steadily to a maximum number at the end of October, falling off to the middle of November, with a few lingering into December in an open fall.

Soon after daylight each morning, the blackbirds leave the rushes, the vast majority flying westward in two or three enormous flocks, each several thousand strong, curving back and forth in long sweeps across the sky, and disappearing over the high ground to the west. Later small scattering flocks fly to all points of the compass. Toward the latter part of the afternoon ( 4 o'clock) the flocks begin to return from the west, a few from other directions, settling at first in the trees, and then in the rushes, until by $4: 30$ or 5 o'clock all have settled there for the night. How far these flocks go to feed, L. B. B. has been unable to ascertain; but it must be many miles, for he has frequently seen flocks flying toward these marshes after 4 P. M. at various places eight or more miles away (e. g., Yale field, Orange; Saltonstall heights, East Haven; West Rock Ridge, some miles north of Lake Wintergreen). They all go off to feed, so that, during the daytime in the fall, blackbirds of all species are rather rare in the immediate vicinity of New Haven. 
In a swampy spot, grown up with bushes and small trees, in the Little River marshes, near Middletown, is a roost where thousands of blackbirds congregate. Here the Purple and Bronzed Grackles outnumber all other species in early November. (J. H. S.)

Family FRINGILLIDÆ. Finches, Sparrows, etc.

Hesperiphona vespertina vespertina (W. Cooper). Evening Grosbeak.

A very rare accidental winter visitor; only recorded in recent years.

Connecticut records. Last week in February, 1890, Cobalt (Chatham), nine or ten seen, two killed, March 6, one male (Bailey, in coll. of J. H. S.) ; March 2, I89o, East Hampton (Chatham), flock of I2-I4 seen, one male killed (in coll. of $\mathrm{H}$. E. Rich) ;2 March Io, I890, Gaylordsville (New Milford), female shot from flock of four or five (E. H. Austin) ; April I2, I9II, Woodstock, male and female taken (in coll. of Wadsworth Atheneum, Hartford).

The following reports of the presence of this species in Connecticut have appeared in print. That of February, 1905, in Litchfield was investigated carefully by Mr. E. S. Woodruff, who decided the birds were not Evening Grosbeaks; and some of the other records seem open to question, as no specimens were collected. Feb. I-I4, I905, Litchfield, flock of thirty (Hutchins) ${ }^{4}$; Feb. 5-22, 1907, Bristol, several seen (Bruen); Oct. I7, I909, Talcott Mt., West Hartford, seen (St. John) ${ }^{5}$; Jan. I3, I9II, Canaan, flock of eight $(\text { Adam })^{5}$; Feb. 12, I9I I, Talcott Mt., West Hartford, one pair seen (St. John) ${ }^{5}$; Feb. I3, I9I I, Taftville, a flock of eight males and eighteen females seen (Werking) ${ }^{5}$; Dec., I9Io-April, I9II, Woodstock, flock of about seventy-five seen ${ }^{6}$.

\footnotetext{
1 Forest and Stream, xxxiv, 10, p. 187.

'Auk, x, 2, p. 207.

3 Auk, vii, 2, p. 211.

- Bird-Lore, vii, 3, p. 173.

Bird-Lore, xiii, 2, p. 94.

- Hartford Courant, Apr. 4, I9r.
} 
Pinicola enucleator leucura (Müller). Pine Grosbeak.

A rather rare and irregular winter resident from November to March; usually absent, but occasionally occurring in considerable numbers.

Earliest record. New Haven, Oct. 3I, I903; Portland, Nov. I, 1903 .

Latest record. New Haven, March II, I884; Portland, April 6, 1903.

Occurrence. New Haven, Feb., March, I883 (G. E. V.); Jan., March, I884 (L. B. B.) ; March, I884 (L. C. S.) ; March, I893 (L. B. B.) ; Jan., I893 (H. W. F.) ; March, I907 (L. B. B.). ; Jan., Feb., I896, large flights in New Haven and Stamford (L. B. B., Andrews, Hoyt) ; Oct., Nov., 1903, and winter, I903-4, large flights, New Haven and Stamford (L. B. B., Hoyt). Portland, Feb., March, I873, Nov., I874-March, I875, Nov., I875, Dec., I877, I878, Jan., I88r, Dec., I882 - Feb., I883, Jan. - March, I884, Dec., I887, Jan. - March, I893, Nov., I895March, I896, Dec., I896, Jan., I898, I900, Nov., I903-April, I904, large flights, Nov., I906, Nov., I907-March, I908, large flights, Jan., I909. Litchfield, Oct. $26-$ Dec. Io, I903, several small flocks, Nov., I906 (E. S. W.). New Canaan, I903-4, 1904-5 (Mrs. Neide, by W. H. H.). Clinton, Nov., I903 (H. W. F.). Westbrook, Nov., I903 (Hooker). Sharon, Jan., I904 (Smith). Lakeville, 1903-4 (J. Truelove). Northford, Nov., 1906 (E. S. W.).

The above records show the irregularity of the occurrence of this species, some winters passing without a record, and other winters having several. It further shows the two greatest flights, the winter of $1895-6$, and $1903-4$, the latter flight being recorded not only from New Haven and Portland, but also from Stamford, Litchfield, New Canaan, Sharon, Lakeville, Clinton, and Westbrook.

Carpodacus purpureus purpureus (Gmelin). Purple Finch. A tolerably common summer resident; winters irregularly in the southern part of the state; most abundant during migrations in March, October, and November.

Spring migration. Earliest record. New Haven, March 9, I904; Portland, March Io, I894. Latest record. New Haven. 
May I5, 1907, I909, May 25, I907 (A. A. S.) ; Portland, May 30, 1889 .

Fall migration. Earliest record. New Haven, Sept. 30, I903; Portland, Oct. 8, I894. Latest record. New Haven, Dec. 4, I896; Portland, Dec. 9, I884.

Winter records. New Haven, Jan. 4, Feb. II, I882, Dec. 28, I883, Feb. I6, Dec. 29, I884, Jan. I5, I902, Feb. 24, I912; Dec. 26, 1906-Feb. 27, 1907, and up to Jan. 2, I908 (A. A. S.). Portland, Dec. I2, I4, 21, I877, Feb. 25, I882, Feb. 29, I884, Dec. 16, 1895, Feb. 3, I896, Feb. I5, I898, Jan. 23, I909.

Nest. In a conifer; about 20 feet from the ground.

Eggs. 2-4; last of May.

Nesting dates. Earliest record. May 25, I898, four eggs (J. H. H.). Latest record. July 8, I884, two eggs (E. H. E.). In Litchfield it is a common summer resident (E. S. W.), but it is rare at that season in the southern part of the state.

Loxia curvirostra minor (Brehm). Crossbill.

$A$ rare and irregular winter resident between November and May.

Earliest record. New Haven, Oct. II, I906; Portland, Dec. Io, 1874 .

Latest record. New Haven, May 12, 1883; Portland, May 2, 1907.

Occurrence. New Haven, May I2, I883 (L. B. B.), April I4, I884 (Trowbridge) ; March 3-9, I888 (H. W. F., A. H. V.) ; Dec., I889 (H. W. F.) ; Jan. 24-5, Feb. I, I890 (L. B. W.) ; Jan. 3I, Feb. I4, I895, Jan. 24, I900, Nov. 4, I903, Oct. I I - Nov. 27, 1906 (L. B. B.) ; Dec. 25, I906 (A. A. S.) ; Dec. 26, 1909 (C. H. P. and A. W. H.). Portland, Dec. Io, I874, Jan 26, I875, April 5, I885, March 14, April 19, I893, March 5, I895, May 2, 1907. Bridgeport, Feb. 27, I900 (Beers) ; Feb. 28, I905 (Hamlin). Stamford, Feb. Io, I890 (L. B. W.) ; Feb., I893 (Porter). New London, winter, I899-I900, large numbers (Hill). Cheshire, Jan., I897 (Hotchkiss).

Loxia leucoptera Gmelin. White-winged Crossbill.

A rare straggler in winter.

Earliest record. New Haven, Nov. 3, I906; Portland, Dec. I4, I899. 
[Bull.

Latest record. New Haven, Feb. 21, I900, Feb. 26, I888 (C. C. T.) ; Portland, May I2, I900.

Connecticut records. Dec. 25, I874, Jan. 27, 1875, Portland (J. H. S.) ; Jan., Feb., March, I875, "not uncommon" (Merriam) ${ }^{1}$ Dec. 7, 9, 1880, Norwich (Case, recorded by S. T. Holbrook) ;2 Feb. 10-26, 1888, New Haven (Trowbridge); Dec., I889, New Haven (H. W. F.) ; Jan. 27, I894 (A. H. V.) ; (for winter, I899-I900, see next paragraph); winter, I903-4, New Canaan (reported by Hoyt); Nov. I, I906, Stony Creek (A. H. V.) ; Nov. 3-Dec. I5, 1906, New Haven, common (L. B. B. and E. S. W.) ; Jan. 5 - Feb. 20, I907, New Haven (A. A. S.) ; Feb. 27-March 2, I909, Middletown, two remained feeding in a spruce tree for several days (Bliss).

Unusual flight, winter, I899-I900. A great flight of this species that visited New England this winter reached southern Connecticut, being frequently noted in several places: Portland, Dec. I4-April I6, frequently seen, especially abundant in Jan. and Feb. (J. H. S.) ; New London, until March I, in large numbers (Hill) ; Saybrook, early in Nov., through Dec. (J. N. C.) ; Guilford, Jan. 24 (A. H. V., L. B. B.) ; New Haven, common in flocks Feb. 6-2I (L. B. B.) ; Bridgeport, Feb. 27, hundreds seen (Beers) ; Stamford, March Io (Hoyt). They obtained á large portion of their food from the fallen seeds of the hemlock, feeding among the dry leaves like sparrows.

Acanthis hornemanni exilipes (Coues). Hoary Redpoll.

Connecticut record. Nov. 24, 1906, East Haven, an adult female shot from a flock of common Redpolls by L. B. B. in company with E. S. W.

Acanthis linaria linaria (Linnæus). Redpoll.

An irregular winter resident; formerly sometimes common; scarce between 1882 and 1906 in southern Conneçticut.

Earliest record. New Haven, Nov. 24, I906, Oct. 29, I906 (A. A. S.) ; Portland, Nov. 27, 1889.

Latest record. New Haven, April 5, 1907 (A. A. S.) ; Portland, May II, Ig00. 
Occurrence. Portland, Feb. 22, 1875, Dec. 6, 1878, Dec. 21, I880, Dec. 30, I882, Feb. 9-10, I883, Dec. 9, 1884, March 29, I888, Nov. 27, I889, April 5, I890, Yan. 30, I896, Feb. I9, I896, Dec. 6, I899, May II, I900. New Haven and vicinity, I866 (Whitney); Jan. I5, 22, 1879 (Woolsey, in Peabody Museum); Jan. 22, 1879 (Osborne, in coll. of L. B. B.) ; about Feb. I5, I883 (Osborne); March 2, I884 (Allen); April I, I890 (L. B. W.) ; Jan. 27, I894 (A. H. V.) ; Feb. 27, I900 (Beers) ; Oct. 29, 1906 (A. A. S.) ; Nov. 24, Dec. 8, 18, 1906, Jan. 22, 27, 1907 (E. S. W. and L. B. B.) ; abundant Dec. 12, 1906 - March I5, 1907 (A. A. S.) ; seen frequently, winter of $1908-9$ (C. H. P., D. B. P., A. W. H.). Bridgeport, Nov. 22, I889 (Lucas, in coll. of Beers). Fairfield, Feb. 22, I900 (Beers). Stamford, Jan., I889 (Camp, in coll. of L. B. B.). Stony Creek, Nov., I902 (A. E. V.). Branford, Jan. 3I, I904 (Nichols). Litchfield, March, I896 (Sanford) ; Nov. 29-Dec. I, I906 (E. S. W.). Danbury, common, winter of 1908-9 (J. C. A. M.). Middletown, March 6, Igog (flock appeared about two weeks before) (Bliss). Middle Haddam, Jan. 28, I912 (G. N. Lawson).

Acanthis linaria rostrata (Coues). Greater Redpoll.

The only Connecticut record is as follows: Dec. I7, 1878, New Haven, two taken by Dr. W. H. Hotchkiss (in coll. of L. B. B.).

Astragalinus tristis tristis (Linnæus). Goldfinch.

An abundant resident, keeping in flocks from September to May.

Nest. Frequently in a maple in the streets of some village, or in some other tree, at from 5 to 30 feet from the ground.

Eggs. 4-6; late in July or early in August.

Nesting dates. Earliest record. July I, I900, five eggs (Hill). Latest record. Aug. 31, 1906, five eggs (A. A. S.).

Spinus pinus (Wilson). Pine Siskin.

An irregular winter resident from November until April; sometimes very abundant, but usually absent.

Earliest record. New Haven, Oct. 8, I906; Portland, Oct. 15, I908. 
Latest record. New Haven, May 7, 23 (?), I888, May I9, 1907 (A. A. S.) ; Portland, May 22, I9I I.

Occurrence. New Haven, Nov., I882, Dec., I884, Oct., I887 (L. B. W.), May, Oct., I888, Oct., I889 (L. B. W.), March, I894, Feb., April, I896, Jan., Feb., April, I900, Oct., I906, Jan., May, I907, Nov., I9II ; Portland, March, I884, Oct., I887 May, I888, Nov., I889-May, I890, April, I892, Dec., I895March, I896, Dec., I899-March, I900, March, I902, May, 1904, Feb., I907, Feb. - May, I908, Oct., I908 - May, I909, May, I9ı I, Feb.-April, I9I2.

Plectrophenax nivalis nivalis (Linnæus). Snow Bunting.

An irregular winter resident from November to March, most frequent near the coast; occasionally in large flocks, but more often not more than a dozen birds together.

Earliest record. New Haven, Nov. 2, I906, Oct. 22, I889 (L. B. W.) ; Portland, Oct. 29, I876.

Latest record. New Haven, March 8, 1882; Portland, March 20, 1875 .

At Stamford it has been taken in September (Schaler), and as late as March 19, I892 (L. H. P.).

Large flocks. Jan. 25, I875, Portland, flock of 200 seen (J. H. S.) ; Feb. I5, 1883, Hamden, a flock that covered acres (Osborne); Jan. I8, I884, Portland, flock of 150 seen (J. H. S.) ; Jan. 27, I898, Orange, flock of 200 (L. B. B.) ; Jan., I905, Danbury, flock of over 200 (J. C. A. M.).

Calcarius lapponicus lapponicus (Linnæus). Lapland Longspur.

A rare and probably accidental late fall migrant.

Connecticut records. Merriam ${ }^{1}$ recorded (1877), that one was taken, Nov., I874, at Suffield by Shores, others at New Haven (no date) by Nichols, and others at Portland by W. W. C. (reported by Grinnell); March I, I875 (approximately), Portland, one received, caught here (W. W. C.) ; Nov. 29, I884, Saybrook, male (H. W. F., in coll. of Brewster); March 29, I888, Saybrook, a male shot (W. E. T., in coll. of J. H. S.) ; Dec. I2, I89I, Stratford, male and female taken (Beers); Nov. 
II, I892, West Haven, male captured (H. W. F.) ; March 4, I893, Bridgeport, four males, (Eames); April 2, I893, West Haven (A. H. V., in coll. of L. B. B.) ; Nov. Io, 1893, West Haven, a male (A. H. V., in coll. of Porter); Dec. 30, I893, Stratford, a female (Dunbar, in coll. of Beers) ; Nov. 22, r895, West Haven, a male (A. H. V.) ; Oct., I904, Winchester, flock of seven or eight seen by Williams (H. K. J.) ; ${ }^{1}$ winter, 1904-5, North Bridgeport, three flocks seen (Hamlin); Feb. I2, 1905, Kent, one seen (H. K. J.) ; Jan. 2I, I907, New Haven, seven seen (A. A. S.).

Poœcetes gramineus gramineus (Gmelin). Vesper Sparrow.

Formerly an abundant summer resident of the upland meadows from April until October; now rare over most of the state, none being found in places along the coast where they were common a few years ago.

Earliest record. New Haven, April 3, I888, March 23, 1907 (C. H. Pangburn) ; Portland, April I, 1905, I908; Bridgeport, March I4, I9O2 ;2 Jewett City, March 20, 1889. ${ }^{2}$

Latest record. New Haven, Nov. 3, I897, 1906, Nov. 4, 1906 (A. A. S.) ; Portland, Oct. $2 \mathrm{r}$, I890.

Winter records. Dec. $3 \mathrm{x}$, 1887, New Haven, one male taken (A. H. V.) ; Feb. r, I889, Guilford, one taken (L. B. B.) ; Feb. I7, 1902, Saybrook, two spending winter there (J. N. C.).

Nest. On the ground, usually in the grass of a dry and sandy field.

Eggs. 3-5; last of May.

Nesting dates. Earliest record. May I, 1906, four eggs (A. A. S.) ; May 3, r88r, four eggs (J. H. S.). Latest record. July 26, r894, three eggs (H. W. B.).

This species seems never to have recovered from the great freeze of 1895 , when so many thousands of birds perished in the southern states, and has become rarer annually since that date.

Passerculus princeps Maynard. Ipswich Sparrow.

A rare migrant and still rarer winter resident, in the beach grass of the seashore from November to March.

1 Job, The Sport of Bird Study, p. 303.

2 Bird-Lore, xiii, 2, p. 86. 
Connecticut records. Nov. 4,1875 , New Haven, female taken (Merriam) ; 1 March 24, I883, Madison, one taken (L. B. B.); Nov. 26, 1884, West Haven, one taken (L. B. B.) ; Nov. I2, I4, Dec. 31, 1887, West Haven, three males (A. H. V.) ; Jan. 2, I888, Woodbridge [?], female (A. H. V.).; Oct. I9, two, Oct. 22, one, 23, one, 30, one, I889, West Haven (L. B. W.) ; Jan. 5, I892, Bridgeport, male (Eames) ; Nov. I, one, Nov. 3, two, I892, West Haven (H. W. F.) ; Nov. 25, 1905, New Haven, male (E. S. W.) ; Oct. 22, 1906, New Haven (E. S. W.) ; Jan. 3, I910, West Haven (A. A. S., in coll. of L. B. B.) ; Nov. 8, I9I I, West Haven, one (L. B. B.).

Passerculus sandwichensis savanna (Wilson). Savannah Sparrow.

An abundant fall migrant in September and October throughout the state; a tolerably common spring migrant in April on the coast, rarer inland; a few breed at the borders of the larger salt marshes and on inland meadows; they very rarely winter.

Spring migration. Earliest record. New Haven, March 29, I90I, March 24, 1906 (E. S. W.), March 24, I883 (L. C. S.); Portland, April 6, I890; Hartford, March 31, I888. ${ }^{2}$ Latest record. New Haven, May 22, I909; Portland, May 27, I88I.

Fall migration. Earliest record. New Haven, Aug. 27, 1897; Portland, Sept. 21, 1892, 1893. Latest record. New Haven, Nov. 21, I904 ; Portland, Oct. 26, I892 ; Hartford, Nov. 29, I888. ${ }^{2}$

Winter records. Jan. I9, I895, West Haven, male taken, Dec. 26, I9I I, East Haven, male taken (L. B. B.).

Nest. In the grass of a meadow bordering the large salt marshes, as those at Hammonasset Point, the Stratford'Marshes, and formerly the Quinnipiac Marshes.

Eggs. 4-5; early in June.

Nesting dates. Earliest record. May 30, I887, four eggs (Watrous). Latest record. June II, I888, four eggs (H. W. F.).

This species is found as a tolerably common summer resident in Litchfield by L. B. W.

Ammodramus savannarum australis Maynard. Grasshopper Sparrow. 
A common summer resident from May to July, chiefly of the dry upper meadows, but breeding also to the borders of the salt marshes of the coast.

Earliest record. New Haven, April 22, 1888; Portland, May 5, 1879, I902, 1904.

Latest record. New Haven, Aug. 6, I896; Litchfield, Sept. I8, I89I (E. S. W.) ; East Hartford, Oct. 21, I885 (W. E. T.).

Nest. On the ground in a meadow.

Eggs. 4-6; the last of May.

Nesting dates. Earliest record. May 23, I897, six eggs ( $\mathrm{J}$. C. A. M.). Latest record. Aug. 22, I895, four eggs (H. W. B.). This species has never been found at Stamford by either Hoyt or Porter.

Passerherbulus henslowi henslowi (Audubon). Henslow's Sparrow.

A summer resident; common locally in Litchfield County, rare elsewhere in Connecticut.

Earliest record. April 27, I905, Litchfield (E. S. W.).

Latest record. Oct. 8, I90I, Litchfield (E. S. W.).

Records outside of Litchfield County. Danbury (Fairfield Co.): May I4, I905, two seen; June I, I905, set of five eggs; May 6, I906, and later, seen; 1908, a number seen (J. C. A. M.). Bridgeport (Fairfield Co.): April 30, I903. ${ }^{1}$ West Haven (New Haven Co.): Oct. 27, I888, one found dead (L. B. W.). Northford (New Haven Co.): I890, two pairs breeding there (A. M. Linsley). ${ }^{2}$ Killingworth (Middlesex Co.): July I8, 1873, one killed (Hall). ${ }^{3}$ Norwich (New London Co.): July 3, I882, set of eggs found ("Hawk").4 Eastford (Windham Co.) : May, I88I, C. M. Jones records ${ }^{5}$ that Henslow's Sparrows have been on the increase there during the past five or six years. Pomfret (Windham Co.) : June I, 1906, heard singing (L. B. B.). Windsor (Hartford Co.) : May 24, I906, male shot (E. S. W.).

Nest. On the ground among the ferns and grasses, composed of dry grass, loosely woven together.

1 Bird-Lore, xii, r, p. 14.

2 Oölogist, viii, 9, p. 180.

3 Merriam, Birds of Conn., p. 37.

4 Young Oölogist, i, I1, p. 154.

- $O$. and $O$., vi, 3, pp. $17 \cdot 18$. 
Eggs. 3-5; early in June.

Nesting dates. Earliest record. June I, 1905, five eggs (J. C. A. M. and L. B. B.). Latest record. Aug. 6, I879, three eggs (C. M. Jones). ${ }^{1}$

This species frequents hillside meadows and swamps partially overgrown with shrubbery.

Passerherbulus caudacutus (Gmelin). Sharp-tailed Sparrow.

An abundant summer resident of the salt marshes from May to October, often lingering into December and probably occasionally wintering.

Earliest record. New Haven, May 4, I887, April 30, 1889 (L. B. W.).

Latest record. New Haven, Nov. I0, I883, Nov. I2, I892 (H. W. F.).

Winter records. Dec. 2, I882, Dec. 3I, I885, Dec. I2, I889, Guilford (L. B. B.).

Nest. In the salt grass, frequently under a little drift material.

Eggs. $3-7$, usually 4 or 5 ; the last of May.

Nesting dates. Earliest record. May 2I, I890, nest with eggs (L. B. W.). Latest record. June 2I, I882, three eggs (L. B. B.). A set of 7 eggs taken, New Haven, May 31, I897 (L. B. B.).

Partial albino records. Dec. 31, 1885, Guilford (L. B. B.) ; Oct. 12, 1900, Nov. 7, 1903, West Haven (L. B. B.) ; Oct. 24, 1904 (L. B. B.), Oct. 8, I909 (L. C. S.), Quinnipiac Marshes, North Haven; Oct. 25, 1905 (E. S. W.), Oct. 14, 27, I905 (L. B. B.), New Haven.

Another anomaly. A few of the feathers of the juvenal plumage on the upper parts remained adherent to the tips of the feathers of the first winter plumage, as the natal down usually does to the juvenal, in specimens of this species taken in West Haven, Oct. 12, I900, Oct. 18, I90I, and Oct. 2I, I903 (L. B. B.).

A female hybrid between this species and the Seaside Sparrow (Passerherbulus maritimus maritimus) was collected near New Haven, May I, I890, by H. W. F. (now in coll. of Brewster). 
Passerherbulus nelsoni nelsoni (Allen). Nelson's Sparrow.

A tolerably common fall migrant in early October; a rare spring migrant the last of May; confined almost exclusively to the salt marshes of the coast, and the wild rice, or water oats, growing along the larger rivers.

Spring migration. Earliest record. New Haven, May 30, 1902. Latest record. New Haven, June I, Igor.

Fall migration. Earliest record. New Haven, Sept. 14, 1904; Portland, Sept. 21, 1892. Latest record. New Haven, Oct. 29, I904; Portland, Oct. 22, 1894; East Hartford, Oct. 30, I89I (W. E. T.).

Unusual record. Litchfield, Sept. 28, 1906 (E. S. W.). (Inland, and at a distance from a large river.)

In large series of $P$. nelsoni nelsoni and $P$. nelsoni subvirgatus, and an equal number of $P$. caudacutus, in coll. of L. B. B., no intermediates can be found.

Passerherbulus nelsoni subvirgatus (Dwight). Acadian Sharp-tailed Sparrow.

A common fall migrant in October, and much rarer spring migrant the last of May, keeping very closely as a rule to the salt marshes of the coast, and the wild rice, or water oats, growing along some of the larger rivers.

Spring migration. Earliest record. New Haven, May 24, I900, May 2I, I892 (H. W. F.). Latest record. North Madison, June 9 (Dr. J. Dwight, Jr.). ${ }^{1}$

Fall migration. Earliest record. New Haven, Sept. 27, r900; Portland, Sept. 26, I892; Lyme, Sept 25, I896 (W. E. T.). Latest record. New Haven, Nov. 8, I904; Portland, Oct. 21, I893.

Passerherbulus maritimus maritimus (Wilson). Seaside Sparrow.

An abundant summer resident of the salt marshes from May until September.

Earliest record. New Haven, April 30, 1894, April 28, 1890 (H. W. F.). 
Latest record. New Haven, Oct. I9, I893, I900, Oct. 30, I889 (L. B. W.).

Winter records. Dec. 30, 1882, Dec. 12, 1889, Guilford (L. B. B.) ; Jan. I8, 1888 (A. H. V.), Jan. I7, I888, Nov. I7, I892 (H. W. F.), New Haven; Dec. I7, I884, West Haven (Webb).

Nest. In the salt grass.

Eggs. 3-5; last of May.

Nesting dates. Earliest record. May 16, 1894, four eggs (L. B. B.). Latest record. July I2, I883, four eggs (J. N. C.).

Partial albinos. Oct. 30, I889, New Haven (L. B. W.) ; Dec. I2, I889, Guilford, male, the entire interscapular region, most of the scapulars, the entire lower parts, and scattered contour feathers in the rest of the plumage, white (L. B. B.) ; Nov. I7, 1892, Quinnipiac Marshes, female with many white feathers (H. W. F.).

Zonotrichia leucophrys leucophrys (J. R. Forster).. Whitecrowned Sparrow.

A rather rare and irregular spring and fall migrant in May and October; more common in the fall.

Spring migration. Earliest record. New Haven, May 4, 1896; Portland, May 12, 1889, 1905. Latest record. New Haven, May I9, I902; Portland, May 22, I888.

Fall migration. Earliest record. New Haven, Sept. 29, I903; Portland, Oct. 2, 1893. Latest record. New Haven, Oct. 26, I905; Portland, Oct. I6, I893.

Winter records. Nov. 28, Dec. 5, I874 (Merriam) ; March 20, 1875, Portland (J. H. S.).

During the fall of 1893 this species was frequently noted in the vicinity of Portland by J. H. S., and in the fall of 1903 near New Haven by L. B. B. Near New Haven it has been noted I9 times in I I different years since I88I by L. B. B. Other records outside of Portland and New Haven include the following: Stamford, May 12, I890 (Hoyt), Oct. 8, I892 (Porter); Litchfield, Oct. Io, I89I (L. B. W.), Oct. IO, I905 (Sanford); East Hartford, May 6, I893, Oct. I6, 19, I895 (W. E. T.) ; Danbury, May 2I, 1905 (J. C. A. M.) ; Stratford, Oct. I4, I89I, I892 (Eames). 
Zonotrichia albicollis (Gmelin). White-throated Sparrow.

A common spring migrant in April and May, and even more common fall migrant in late September and October; occasionally winters; rare summer resident.

Spring migration. Earliest record. New Haven, March II, I882; Portland, April I3, I892. Latest record. New Haven, May 25, 1909; Portland, May 21, 1888.

Fall migration. Earliest record. New Haven, Sept. I3, I904; Portland, Sept. 15, 1877. Latest record. New Haven, Nov. 20, I907; Portland, Nov. 28, I885.

Winter records. Jan. 6, I882, Dec. 19, 1900, Guilford (L. B. B.) ; Jan. I, I886, Dec. 25, I902, Feb. 7, 1903, Jan. 26, 1905, Portland (J. H. S.) ; Dec. 20, I904, Woodmont (L. B. B.); abundant from Dec. 13, 1906, until spring of 1907, New Haven (A. A. S.) ; Dec. 25, I909, New Haven (C. H. P. and A. W. H.).

Summer records. June I8, I904, Salisbury (J. H. S. and L. B. B. ) (?) ; July 8, 1905, Winsted (J. H. S.) ; June 26 , I906, Litchfield (E. S. W.).

Spizella monticola monticola (Gmelin). Tree Sparrow.

A common winter resident, arriving in November and leaving in March; very abundant during these two months.

Earliest record. New Haven, Oct. 16, 1900, Oct. 15, 1906 (A. A. S.) ; Portland, Oct. I0, I89o.

Latest record. New Haven, April 18, 1885, April 28, 1907 (A. A. S. and Pangburn); Portland, April 25, 1907, 1908.

The majority of these birds wintering in this state seem to be males. Their songs may be heard almost any mild day during the winter.

Spizella passerina passerina (Bechstein). Chipping Sparrow.

An abundant summer resident of orchards and gardens from April to October.

Earliest record. New Haven, April 2, 1904, March 28, 1902 (A. A. S.) ; Portland, April 5, I892, I910; Hartford, April 4, 1906; Jewett City, April 5, 1907. ${ }^{1}$

1 Bird-Lore, xi, 6, pp. 256-7. 
Latest record. New Haven, Oct. 3I, I902; Portland, Oct. 23, I890, I909; Hartford, Oct. 29, I887;1 East Hartford, Nov. 19, I 888 (W. E. T.).

Winter records. Feb. 23, I877 (Grinnell) ;2 Nov. I7, I905, Light House Point, New Haven (E. S. W.) ; Dec. 8, I906, New Haven (E. S. W.).

Nest. In a bush, vine or tree, 5-I5 feet from the ground.

Eggs. 2-5; the last of May.

Nesting dates. Earliest record. May 10, 1896, four eggs (J. C. A. M.). Latest record. Aug. 23, I883, two young (L. B. B.).

The Chipping Sparrow chooses some very odd places for its nest. It has been found built on the ground (L. B. B. and J. C. A. M.), in very low bushes just a few inches from the ground, on a dead limb (J. H. S.), etc.

A set of five eggs was taken near New London, May 29, I897 (J. H. H.), and an unspotted egg in North Haven, May 23, I883 (W. A. Robbins, in coll. of L. B. B.).

A female, many of whose breast feathers had dark central shafts - as in juvenal Plumage - was taken in East Haven, May Ig04 (L. B. B.).

Spizella pusilla pusilla (Wilson). Field Sparrow.

An abundant summer resident from April to November ; rarely wintering.

Earliest record. New Haven, March 29, I898, March 14, 1902 (A. A. S.) ; Portland, March 28, 19 Io.

Latest Record. New Haven, Nov. 30, I90I ; Portland, Oct. 26, 1892.

Winter records. Dec. 2, I875 (Merriam) ;2 Dec. 3I, I883, New Haven (L. C. S.) ; Jan. 3I, I885, New Haven (L. B. B.) ; Jan. I, I886, Portland (J. H. S.) ; Jan. I I, 26, I886, Jan. 20-6, I887, East Hartford (W. E. T.) ; Jan. 5, I891, Feb. 6, I I, I892, New Haven (Hedges) ; Jan. 26, I901, Dec. I8, I906, New Haven (L. B. B.) ; Jan. 26, I907, North Haven (E. S. W.) ; a small flock, Jan. I9 - Feb 4, I906, Dec. I I, 1906-Feb. 26, 1907, and Dec. 7,1907 , New Haven (A. A. S.).

1 Bird-Lore, xi, 6, pp. 256-7.

2 Merriam. Birds of Conn., p. 39.

$8 A u k$, iv, 3. p. 259. 
Nest. On the ground near the borders of an open field, or I to 3 feet from the ground in a bush, frequently a juniper.

Eggs. 3-5; late in May.

Nesting dates. Earliest record. May 10, I887, four eggs (H. W. B.), May Io, I896, four eggs (J. C. A. M.). Latest record. July 29, 1900, three eggs (J. C. A. M.).

Partial albinos. Aug. 26, I893, Stamford, entire plumage unusually pale, tail feathers almost white (Porter); May 2, I899, New Haven, male with scattered white contour feathers (L. B. B.) ; Jan. 26, I907, North Haven (E. S. W.).

Junco hyemalis hyemalis (Linnæus). Slate-colored Junco.

An abundant fall and spring migrant in October, November, and March, and common winter resident.

Earliest record. New Haven, Sept. I9, I900; Portland, Sept. I5, 1903 .

Latest record. New Haven, May 4, I898; Portland, April 27, 1907.

Summer record. A young male in striped juvenal plumage taken at New Haven, July 27, 1903 (L. B. B.).

Partial albinos. A young bird having the crown and most of the wings and tail ashy white, taken at New Haven, Dec. 2I, I900 (L. B. B.). Birds with the greater primary coverts spotted with white have been taken near New Haven, Oct. 25, I90I, Nov. IO, I903, and March 29, I904 (L. B. B.).

Melospiza melodia melodia (Wilson). Song Sparrow.

An abundant summer and tolerably common winter resident, the great majority arriving early in March and leaving in November.

It winters regularly along the shores of the Sound, and was especially abundant near New Haven and Bridgeport in December, 1904.

Period of singing. Earliest record. Feb. 2I, I900. Latest record. Oct. 24, I892.

Nest. On the ground, or in bushes and vines, 3-8 feet from the ground, usually partially covered with dry grass, weeds, or leaves, so as to be protected.

Eggs. $3-8$; usually 4 or 5 ; the last of May. 
Nesting dates. Earliest record. May 3, 1886, four eggs (Webb). Latest record. Aug. 24, I883, three eggs (L. B. B.).

Unusual set. May 24, I894, Stamford, eight deserted eggs found, all closely resembling one another (Porter).

Partial albino. A female with head and throat unspotted white, taken in Bridgeport, May 28, I890 (Eames, in coll. of H. W. B.).

Melospiza lincolni lincolni (Audubon). Lincoln's Sparrow.

A rare fall and still rarer spring migrant in September and May.

Spring records. Merriam records ${ }^{1}$ one taken in spring of 1875, at Saybrook, by J. N. C., three in spring of I877, at Lyme, by J. G. Ely, and three more at Suffield, by E. I. Shores; April 24, I886, East Hartford (W. E. T.) ;2 May 18, I890, Stamford Porter); May 23, I892, East Hartford, male and female shot (W. E. T.) ; May 15, 1900, New Haven (L. B. B.) ; May, I901, Stamford (Hoyt); May 12, 1907 (A. A. S.).

Fall records. Sept. 21, I885, East Hartford, female (W. E. T.) ; Sept. 15, 1887, Sept. 27, 1888, New Haven (H. W. F.) ; fall, I891, Stamford (O. P. Hoyt) ; Sept. 21, I892, Portland, one taken, Sept. 21, 27, 30, Oct. 3, 5, 1893, Portland, many seen, eight obtained by W. E. T. (in coll. of J. H. S.) ; Sept. 2, I893, Stamford (Porter) ; Sept. 14, 24, New Haven (L. B. B.) ; Sept. 23, New Haven (A. H. V.) ; Sept. 25, 28, Oct. 26, I895, New Haven (H. W. F.) ; Sept. 29, Oct. I3, I903, New Haven (L. B. B.) ; Oct. I3, I906, New Haven (E. S. W.) ; Oct. 6, I9I I, New Haven (L. B. B.).

Melospiza georgiana (Latham). Swamp Sparrow.

A common spring and abundant fall migrant in April, May, September, and October; a tolerably common summer resident of the northern part of the state, but in the southern part known to breed only in the upper section of the Quinnipiac Marshes, where it is common, and near Bridgeport; very rare winter resident.

${ }^{1}$ Merriam, Birds of Conn., pp. 38-9.

$2 A u k$, iii, 4, p. 487.

s Auk, x, 2, p. 206. 
Spring migration. Earliest record. New Haven, Apri1 2, 1895, I901; Portland, March I4, I893. Latest record. New Haven, May 23, I882, 1907 (A. A. S.) ; Portland, May 2I, I900.

Fall migration. Earliest record. New Haven, Sept. 16, 1904; Portland, Sept. 21, 1892, 1893. Latest record. New Haven, Nov. II, I903, Nov. 26, 1905 (E. S. W.) ; Portland, Nov. 28, I885.

Winter records. Jan. 27, 1883, New Haven, one taken (W. Kent); March 7, I888, New Haven, one taken (H. W. F.); Jan. 3, I903, Bethel, one taken (R. C. Judd); Feb. 12, 1906, Portland (J. H. S.) ; Jan. II, I9ro, New Haven (C. H. Pangburn, in coll. of L. B. B.) ; Dec. 26, I9I I, East Haven (A. W. H., D. B. P. and L. B. B.).

Nest. In a tussock of marsh grass in a fresh-water swamp.

Eggs. 4-5; the first part of June.

Nesting dates. Earliest record. May 18, 1890, four eggs (H. C. Judd). Latest record. June 22, 1907, four eggs (J. H. S.).

Partial albinos. Young female taken at New Haven, Oct. I3, I903, has greater wing coverts white and much white in rest of plumage (L. B. B.) ; another female taken at Litchfield, Oct. 12, 1903, has back pure white and throat and breast chiefly white (E. S. W.).

\section{Passerella iliaca iliaca (Merrem). Fox Sparrow.}

- A common spring migrant in March and early April, and a common fall migrant the last of October and November; wintering rarely.

Spring migration. Earliest record. New Haven, March 6, I894, Feb. 25, 1906 (E. S. W.) ; Portland, March 2, I883. Latest record. New Haven, April I8, I885, April 25, 1907 (A. A. S. and Pangburn); Portland, April 26, 1875.

Fall migration. Earliest record. New Haven, Oct. 2, 1907, Sept. I6, I895 (H. W. F.) ; Portland, Oct. I7, I890, I893. Latest record. New Haven, Nov. 30, I90I ; Portland, Nov. 27, I874.

Winter records. Jan. 5-6, I882, Dec. 18, 1903, Jan. 9, 1905, Guilford (L. B. B.) ; Dec. 29, 1883, Bridgeport (C. K. Averill); 
Dec. 5, 1906, Dec. 24, 1907, New Haven (A. A. S.) ; Dec. 25, I909, New Haven (C. H. P. and A. W. H.) ; Dec. 26, I9I I, East Haven (A. W. H., D. B. P. and L. B. B.). Bridgeport, rare, but occurs in winter (Eames).

This species suffered severely in the winter of 1895 , and not until about I90I did it regain its former numbers. For example, J. N. C. wrote in March, I902, that they were common at Saybrook for the first time in five years.

They often sing as they pass through the state, a large flock in full song having been noticed by L. B. B. on such winter dates as Nov. II (1903), Nov. 2 (1904), March I5 (1894).

Pipilo erythrophthalmus erythrophthalmus (Linnæus). Towhee.

A common summer resident from the latter part of April until the middle of October. A rare winter resident.

Earliest record. New Haven, April 24, I885, April I4, I904 (A. A. S.) ; Portland, April 2r, 1909.

Latest record. New Haven, Nov. 3, 1883; Portland, Nov. II, 1903 .

Winter records. Jan. 22, 1876, Portland (J. H. S.) ; Feb. I I, I882, Woodbridge (L. B. B.) ; Dec. 29, I884, Guilford (L. B. B.) ; Jan. I6, I899, Guilford (L. B. B.) ; Dec. 26, 1904, Stratford (J. C. A. M.) ; Jan. 16, 1905, East Haven (H. W. F.) ; Dec. 23, I900, New Haven (A. A. S.).

Nest. Located on the ground in brush, under a bush, or at the foot of a tree; occasionally a foot or two from the ground in a small tree.

Eggs. 3-5; May 25-30.

Nesting dates. Earliest record. May 16, I894, four eggs (J. C. A. M.). Latest record. July $2 \mathrm{I}$, I895, three eggs (J. C. A. M.).

Probably eggs are laid at an even later date, as two males that were evidently breeding were taken by L. B. B., July 26 , 1904. Others were heard singing, July 27, 1903, and Aug. 9, I904; and a female still in juvenal plumage was collected, Sept. $8,1903$. 
Cardinalis cardinalis cardinalis (Linnæus). Cardinal.

Connecticut records. Merriam ${ }^{1}$ records that a specimen was found in 1874 in New Haven by Mr. Thomas Bostwick and was identified as a wild bird by Grinnell; May, 1885, Trumbull, a pair seen (Beers); a male in the collection of M. B. Tobey of Canaan may have been taken here, but is open to great doubt, since the collection contains a number of birds from the South and the West, and is not labelled; late in May, about I900, Winchester, a male with full crest seen (Williams). ${ }^{2}$

Zamelodia ludoviciana (Linnæus). Rose-breasted Grosbeak.

A common summer resident from May until July.

Earliest record. New Haven, May 5, 1897, 1906, April 30, 1906 (A. A. S.) ; Portland, May I, I890, I891, I896, 1906, 1907. Average of 32 years' records, May 7 (J. H. S.).

Latest record. New Haven, Sept. 24, I906, Sept. 28, I892 (H. W. F.) ; Portland, Sept. 28, 1892.

Winter records. Nov. 25, 1874, New Haven (Merriam) ; Nov. I5, 1904, Bridgeport, an adult male found dead, apparently killed by a recent storm (Beers). This was a peculiarly interesting specimen, in that the recently assumed winter plumage differed from that of the spring only in having a few brown tips to the feathers of head, back, throat, breast, and flanks, these tips hiding the black only on the back, and in having a conspicuous white malar stripe.

Nest. In the top of a slender tree, or bush, e. g., elder, willow, elm, in a thicket in swampy woods ; $5-15$ feet from the ground, occasionally higher.

Eggs. 3-5; early in June.

Nesting dates. Earliest record. May 19, I891, four eggs (J. C. A. M.). Latest record. June 18, I888, three eggs (E. H. E.) ; June 18, 1900, three eggs (L. B. B.).

Males hatched the previous year have occasionally in the spring many of the feathers of the throat and upper parts tipped with brown, and the rose-red of the breast prolonged almost to

1 Merriam, Birds of Conn., p. 44.

2Job, The Sport of Bird Study, p. 305.

${ }^{3}$ Merriam, Birds of Conn., p. 43. 
the bill. One in the collection of Porter has many of the feathers of the head and upper parts edged with rose-red.

In 1849, by request of the late Dr. Jno. C. Comstock, many of whose notes are published in this report, the name of the Rosebreasted Grosbeak was added to the list of song birds protected by the first act of the Connecticut legislature, and probably the first legislation in New England, for such a purpose. At that time the bird was scarcely known, but now it appears to be increasing in numbers throughout the state (J. H. S:).

\section{Passerina cyanea (Linnæus). Indigo Bunting.}

\section{A common summer resident from May until August.}

Earliest record. New Haven, May 8, I897, I908, May 3, I888 (Webb) ; Portland, May 6, I887, I894; Litchfield, May 3, 1905 (E. S. W.). 1893.

Latest record. New Haven, Oct. 2, I895; Portland, Oct. I6,

Nest. In a shrub or bush, rarely in the woods; $2-3$ feet from the ground.

Eggs. 3-5; early in June.

Nesting dates. Earliest record, May 30, I900, three eggs (J. C. A. M.). Latest record. Aug. 18, 1906, eggs, hatched Aug. 29 (A. A. S.).

Spotted eggs. Rare. Set of four, June 5, I890, New Haven (Hedges, in coll. of L. B. B.) ; one, June 6, 1883, New Haven (Robbins and L. B. B.).

A female with the crown, rump, and upper tail feathers blue, and many blue feathers in other parts of the plumage, especially on the throat and breast, and the abdomen white, was collected by $\mathrm{H}$. W. F. near New Haven, May 26, 1892.

Heard singing as late as July 27 (I903) and July 22 (1904) (L. B. B.).

\section{Spiza americana (Gmelin). Dickcissel.}

Formerly an abundant summer resident, but none have been taken in Connecticut in many years.

Up to 1840 this species was very abundant near New Haven; in fact it was almost as common as the English Sparrow is to-day, according to Professor Silliman of Yale, who thus reported it to Professor Verrill. A male and female of this species are in the 
Peabody Museum, these specimens having come from the Yale Natural History Society, in a collection of mounted birds, some of which were collected by Linsley at Stratford, and the others probably near New Haven.

Hoyt records a specimen being seen near Stamford in the summer of 1904 by Miss Fessenden; but the possibility of mistaking a male English Sparrow for the Dickcissel has been more than once proved by experienced ornithologists.

\section{Family TANGARIDÆ. Tanagers.}

Piranga ludoviciana (Wilson). Western Tanager.

A young male of this species was collected by $\mathrm{H}$. W. Flint on Fair Haven Heights, in New Haven, Dec. 15,1892 . "It is not an escaped bird, as the feet and plumage clearly indicate."1

Piranga erythromelas Vieillot. Scarlet Tanager.

A common summer resident from May until September.

Earliest record. New Haven, May 1, 1907; Portland, May 3, 1908.

Latest record. New Haven, Oct. Io, I90I; Portland, Oct. 9, r891.

Nest. In a tree in orchard or woodland, 5-20 feet from the ground.

Eggs. 3-5; early in June.

Nesting dates. Earliest record. May 28, 1898, four eggs (L. B. B.). Latest record. Aug. Io, I909, three eggs (M. T. Smith).

Unusual eggs. Occasionally the eggs are very faintly and finely spotted, altogether lacking the usual bold markings; e. g., June 5, 1888, New Haven, set of four (Parsons) ; May 28, 1898; set of four (L. B. B.) ; June 2, 1903, Chester, one (Canfield) ; May 29, I898, near New London, set of five (J. H. H.).

Variations in plumage of the males in the spring are many and interesting; e. g., one with the prevailing color of the plumage except the wings and tail coral-red, taken by A. H. V. and L. B. B., May I7, I894; another with the prevailing color rufous, taken by L. B. B., July 9, 1904; others show patches of cadmium-yellow, or have occasionally the lesser coverts and 
bases of the greater coverts chrome-yellow or vermilion, or even more rarely the greater coverts tipped with vermilion. Adult males occasionally complete the fall moult before leaving for the south, specimens in full winter dress having been collected by L. B. B. the last of September.

Piranga rubra rubra (Linnæus). Summer Tanager.

Very rare summer visitant.

Connecticut records. Linsley recorded it from Stratford and New Haven. Merriam ${ }^{1}$ noted that Shores killed one at Suffield, July 2I, I876; May 23, I882, Whitneyville, female collected (L. C. S. in company with L. B. B.) ; April 8, 1886, New Haven, male taken (Hooker, in coll. of L. B. B.) ; April 28, I893, Portland, a male which had died of exposure taken (Hurlburt, specimen examined by J. H. S.) ; April 27, 1895, Old Saybrook, male taken (J. N. C.). ${ }^{3}$

\section{Family HIRUNDINID王. Swallows.}

Progne subis subis (Linnæus). Purple Martin.

Formerly an abundant summer resident from May until July; now rapidly decreasing throughout the state.

Earliest record. New Haven, April 20, I889; Portland, April 4, 1903 .

Latest record. New Haven, Sept. 2, 1885; Portland, Sept. 19, 1892.

Nest. Breeds in small colonies in martin-houses, though it has also been noted nesting in a hollow fence rail. ${ }^{4}$

Eggs. 4-6; early in June.

Nesting dates. Earliest record. May 2I, I880, four eggs. ${ }^{4}$ Latest record. June 19, I898, six eggs (Hill).

Formerly Purple Martins bred commonly around New Haven and even in the center of the city; but their numbers decreased in the eighties with the multiplication of the English Sparrows, so that they are now seldom seen there except as a rare migrant. In fact the last record in the breeding season for New Haven

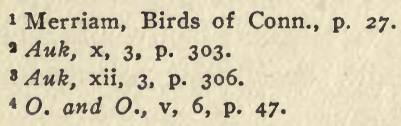


by L. B. B. is June I7, I893, and he has seen none at any season there since 1905 .

In Guilford Martins were abundant much later, but their numbers have markedly decreased, and now most of the martin-boxes are untenanted except by English Sparrows. Only one small colony there and another in Madison were found by L. B. B. in the summer of 1904. Hoyt reports that there was in 1905 at least one colony still breeding in Stamford. Colonies in Middletown and Portland were breeding in I9I2. These birds should be encouraged by erecting boxes for them, care being taken to protect them from the English Sparrow, their worst enemy.

\section{Petrochelidon lunifrons lunifrons (Say). Cliff Swallow.}

A locally common summer resident from May until August; over most of the state only a tolerably common spring and fall migrant; decreasing, but not as rapidly as the Purple Martin.

Earliest record. New Haven, May 3, I882, April I5, I877 (Osborne), ${ }^{1}$ April 21, 1906 (E. S. W.) ; Portland, May I9, I905; Litchfield, April 30, I905 (E. S. W.).

Latest record. New Haven, Sept. I8, I895, Sept. 30, I907 (A. A. S.) ; Portland, Sept. I4, 1877.

Nest. Breeds in colonies under the eaves of barns and outbuildings.

Eggs. 3-5; early in June.

Nesting dates. Earliest record. May 30, I898, five eggs (Hill). Latest record. June I3, I882, four eggs (L. B. B.).

Unusual eggs. In a set of five eggs collected in Meriden, May 3 I, I885 (L. B. B.), one egg is pure white with a few purplish brown specks at the larger end, another pale cream-buff, heavily blotched with dull heliotrope-purple and mummy-brown at the base, while the other three are normal.

Albino. Aug. 22, 1902, Gaylordsville, one seen (Austin).

Hirundo erythrogastra Boddaert. Barn Swallow.

An abundant summer resident from May until August.

Earliest record. New Haven, April 13, I887, April 7, I888 (Webb) ; Portland, April 6, I889.

Latest record. New Haven, Sept. 2I, I903, Oct. 29, I888 (L. B. W.) ; Portland, Oct. I9, I89I.

${ }^{1}$ Merriam, Birds of Conn., p. 30. 
Nest. On a beam or against a rafter in a barn or shed, or more rarely under the eaves.

Eggs. 4-7; last of May.

Nesting dates. Earliest record. May I5, I894, one egg (L. B. B.). Latest record. Sept. 3, 1892, five eggs slightly incubated (Dickerman of Danbury). ${ }^{1}$

A set of seven eggs was collected by L. B. B. in New Haven, May 24, I893.

Iridoprocne bicolor (Vieillot). Tree Swallow.

An abundant spring, summer, and fall migrant in April and May, and from July to October; a rare summer resident, but more common in Litchfield county; still rarer winter resident.

Spring migration. Earliest record. New Haven, March 25, 1893; Portland, March 27, I899. Latest record. New Haven, May 27, 1902; Portland, May I7, I901.

Fall migration. Earliest record. New Haven, July 8, I904; Portland, July I4, I886. Latest record. New Haven, Nov. 2I, 1900; Portland, Nov. I, I9Io.

Winter records. Winter, IgOI-2, several spent the winter at Saybrook (J. N. C.), where about a dozen were seen Jan. 3I, and 20 or 30 more by L. B. B., March 18 , besides a probable straggler from that flock in Guilford, March 24. The stomachs of three collected were full of bayberries upon which they had lived during the winter.

Nest. Usually in a hollow tree in an old woodpecker's nest, IO-I 5 feet from the ground.

Eggs. 4-6; early in June.

Nesting dates. Earliest record. May 24, I884, four eggs ( $\mathrm{J}$. H. S.). Latest record. June 20, I898, five eggs (Hill).

In the spring there appear to be two flights, one chiefly of adult males early in April, the other largely of females about the middle of May. This swallow is the earliest migrant to return from the north, as many as 500 having been seen near New Haven as early as July I4 (I904) by L. B. B., and the last swallow to stay with us in the fall, several hundred having been seen by him on Oct. 6, I903, and about a thousand on Oct. 24, I898, and Oct. 13, I905, which had been spending the nights in the rushes on the Quinnipiac marshes. 
Riparia riparia (Linnæus). Bank Swallow.

A summer resident from May until August, abundant locally where suitable banks occur along the larger rivers, but absent through much of the state except as a migrant.

Earliest record. New Haven, April 25, I888; Portland, April I7, I882.

Latest record. New Haven, Sept. I I, I902, Sept. 23, 1906 (A. A. S.) ; Portland, Sept. 25, I89I.

Nest. In a narrow burrow several feet deep, excavated by the birds in a sand bank, usually on the bank of a river; generally composed largely of feathers.

Eggs. 2-6; the last of May.

Nesting dates. Earliest record. May I7, 1872, one egg, May 2I, four eggs (J. H. S.) ; May 22, I904, six eggs (J. C. A. M.). Latest record. June 14, I893, three eggs (J. C. A. M.).

Unusual set. June 17, 1905, Litchfield, two incubated eggs (E. S. W.).

Stelgidopteryx serripennis (Audubon). Rough-winged Swallow.

A tolerably common summer resident of the southern border of the state from May until August; much rarer in the interior.

Earliest record. New Haven, May I, I897, April 30, I907 (A. A. S.).

Latest record. New Haven, Aug. I3, I903.

Unusual record. March 3, I888, Stamford (Hoyt, in coll. of L. B. B.).

Nest. Located in a burrow in a sand bank, usually excavated by the birds themselves, wide enough to admit a man's arm, and somewhat broader than high, and from 3 to 5 feet long. Nest large and bulky and usually composed of sticks, weed stalks, grass, and leaves. Nests have also been found in empty pipes (A. A. S. and Case), ${ }^{1}$ in an old Kingfisher's nest (E. S. W. and J. C. A. M.), in a crevice of the arch of a stone bridge (Porter, May 26, 1894), and in the drain-pipe of a bridge (Beers, May 30, 1904).

Eggs. 5-7; the last of May.

Nesting dates. Earliest record. May 22, 1904, seven eggs (J. C. A. M.). Latest record. June 24, I900, five eggs (Hill). 
The bank selected for the nest is usually a.small one, often in the woods or at the roadside, seldom near the water. Usually only one pair, and very rarely more than two, are found breeding at one place, but a colony of at least ten birds was found in New Haven, June 24, 1907 (A. A. S.). As a rule these swallows nest alone, though one pair was found breeding in a colony of Bank Swallows (J. C. A. M., I904).

This Swallow has been seen in New Milford (E. H. Austin) and in Kent (H. K. J.). ${ }^{1}$ A female, and three young just beginning to fly, seen at Portland, July I3, I888, by J. H. S.

\section{Family BOMBYCILLIDA. Waxwings.}

Bombycilla garrula (Linnæus). Bohemian Waxwing.

Connecticut records. Feb. II, I875, New Haven, one seen (?) (Smith) ;2 Merriam further records ${ }^{2}$ that Dr. Wood of East Windsor Hill shot one by accident while shooting into a flock of Cedar Birds (specimen now in Atheneum collection, Hartford); fall, I899, Torrington, one shot from a flock of Cedar Birds (in possession of Hochstein). ${ }^{1}$

Bombycilla cedrorum Vieillot. Cedar Waxwing.

A tolerably common summer resident and irregular winter resident, often abundant in the migrations from March to May, and from September to November.

Earliest record. New Haven, March 2, 1904; Portland, March 7, 1878.

Latest record. New Haven, Nov. 22, I900; Portland, Oct. 9, 1892.

Winter records. New Haven, Dec., I88I, Jan., Feb., Dec., I882, Jan., I900, I902 ; Portland, Jan., I884, Dec., I885, Jan., I886, Feb., I887, 1893, 1895.

Nest. Most frequently in an apple or cedar growing in open country at from Io to I5 feet from the ground; made of dead twigs, which the bird has once been seen to break off from the lower limbs of a tree.

Eggs. 4-5; late in June. 
Nesting dates. Earliest record. June II, I88I, one egg (L. B. B.) ; June 15, 1884, five eggs (Eames). Latest record. Aug. 23, I874, four eggs (J. H. S.). Thirteen nests of this bird were found in one thicket of young maples at West Haven in August and September, 1906, and four other nests were discovered there after the leaves had fallen (A. A. S.).

A few of the rectrices are occasionaily tipped with red in both sexes, and more rarely in the male many of the primaries; while the red tips of the secondaries are not unusual in juvenal plumage.

\section{Family LANIID压. Shrikes.}

Lanius borealis Vieillot. Northern Shrike.

A winter resident from November to March; probably occurring regularly, but seldom in large numbers, and not nearly as common at present as twenty years ago.

Earliest record. New Haven, Nov. 6, I901; Portland, Oct. $26,1888$.

Latest record. New Haven, March 31, 1906, April 17, 1907 (A. A. S. and Pangburn), April I8, I885 (F. W. Wentworth); Portland, April 4, 1873.

In March, before going north, the males occasionally mount to the top of some tree standing in rather open country, and warble in a harsh voice a song somewhat like that of a Bluebird. This singing has been watched by L. B. B. on March 28,1883 , and March 15, 1894, some of the notes on the latter occasion resembling those of the Chickadee.

Lanius ludovicianus migrans W. Palmer. Migrant Shrike.

A rare and irregular fall migrant and winter resident from August until February, occurring chiefly near the salt marshes along the coast.

Earliest record. New Haven, Aug. 18, 1903; Portland, Sept. 20, 1899 .

Latest record. New Haven, Feb. 15, 1902; Portland, April II, 1900 .

Breeding record. Latter part of May, about 1893 , Winchester, nest with five eggs found in an apple orchard (Williams, recorded by H. K. J.). ${ }^{1}$

1 Job, The Sport of Bird Study, p. 306. 
Connecticut records. Nov., 1876, Portland, one taken (Goff, in coll. of W. W. C.) ; Aug. 22-4, I882, Guilford, seen (L. B. B.) ; Jan. 30, I883, Branford, male taken (Nichols, in coll. of L. B. B.) ; late Aug., I880, one seen, and late Aug., I885, two seen together, one shot, Bridgeport (Averill) ; July, I886, New Haven, male taken (H. W. F.) ; Aug. I5, I888, North Haven, male taken (A. H. V., in coll. of Porter) ; Aug. 29, I888, Bridgeport, young female (Averill, in Bpt. Sci. Soc.) ; Aug., I892, New Haven (L. C. S., in coll. of L. B. B.) ; Sept. I8, I895, North Haven, young female (L. B. B.) ; Sept. 20, Dec. 7, I899, Portland, male (in coll. of J. H. S.) ; April I I, I900, Portland, female (in coll. of J. H. S.) ; Feb. 25, I90I, Stamford, male (Hoyt) ; Sept. I8, I90I, Saybrook, one seen (J. N. C.) ; Jan. I5, I902, Portland, female (J. H. S.) ; Jan. 20, I902, North Haven, adult male (Ludington, in coll. of L. B. B.) ; Feb. I5, I902, New Haven, female (L. B. B.) ; Oct. 2, I902, Hamden, female (L. B. B.) ; Aug. 18, I903, Branford, seen (L. B. B.) ; Oct. 6, I903, North Haven, seen (L. B. B.) ; Nov. 6, I903, Orange, female (Sherman, in coll. of L. B. B.) ; Sept. 16, I904, Stratford, young male (Beers and Perry); Oct. 25, I904, Middletown, female (in coll. of J. H. S.) ; Feb. I7, I905, South Norwalk (Smith, recorded by J. A. Allen). ${ }^{2}$

Family VIREONIDÆ. Vireos.

Vireosylva olivacea (Linnæus). Red-eyed Vireo.

An abundant summer resident of the woodland from the middle of May until September.

Earliest record. New Haven, May 4, I882, May 2, I906 (A. A. S.) ; Portland, April 26, 1896.

Latest record. New Haven, Oct. I0, I901, Oct. I2, I906 (A. A. S.) ; Portland, Oct. 8, I890; Hartford, Oct. 25, I900. ${ }^{3}$

Nest. Usually in a small tree or bush in dark woodland, 3 to 20 feet from the ground.

Eggs. 3 or 4 ; early in June.

Nesting dates. Earliest record. May 25, 1906, one egg, May 28, four eggs (J. H. S.) ; May 28, 1889, four eggs (C. F.

- Bird-Lore, xi, 2, p. $8 \mathrm{r}$. 
Hedges). Latest record. Aug. 4, I882, two eggs and two Cowbirds' eggs (L. B. B.).

This species is especially persecuted by the Cowbird; and, of I9 nests with 3 or more eggs recorded by L. B. B., I I contained eggs of this parasite.

It sings constantly its monotonous ditty through the summer months, and has been heard repeating it by L. B. B. as late as Sept. 8 (I902) and Sept. I4 (I903).

Vireosylva philadelphica Cassin. Philadelphia Vireo.

A very rare spring and fall migrant.

Spring records. May 19, I888, near New Haven, male taken (A. H. V.) ; May 18, 1900, Westville, male taken (L. B. B.) ; May 17, I905, Litchfield, female taken (E. S. W.).

Fall records. Sept. 2I, I893, Gildersleeve Island, Portland, male taken (S. R., in coll. of J. H. S.) ; Sept. I7, I894, same locality, female taken (S. R., in coll. of J. H. S.) ; Oct. 4, I899, Litchfield, female taken (E. S. W.) ; Sept. I4, I905, East Haven, male taken (L. B. B.) ; Sept. 2I, I905, New Haven, female taken (L. B. B.).

Vireosylva gilva gilva (Vieillot). Warbling Vireo.

A common summer resident of the shade trees of the villages and cities, from May until September; but rare elsewhere in the state.

Earliest record. New Haven, May 2, I899; Portland, April 26, I908; Jewett City, April 20, 1898.2

Latest record. New Haven, Sept. 14, I903, Sept. 19, 1906 (A. A. S.) ; Portland, Sept. I7, I895; Litchfield, Oct. I, I890 (L. B. W.).

Nest. High in an elm or maple; occasionally in an apple tree.

Eggs. Usually 4; early in June.

Nesting dates. Earliest record. May 26, 1895, four eggs (H. R. Buck). Latest record. June 14, 1876, four eggs (J. H. S.).

This bird has been heard singing as late as Sept. I2 (1885) and Sept. I4 (I903) (L. B. B.).

10 . and 0. , xiii, 7, p. 103.

2 Bird-Lore, xi, 2, p. 79. 
Lanivireo flavifrons (Vieillot). Yellow-throated Vireo.

A tolerably common summer resident of the orchards, shade trees, and more open woodland, from May until August.

Earliest record. New Haven, April 27, I886; Portland, April 26, 1889 .

Latest record. New Haven, Sept. 20, 1900, Oct. I2, 1906 (A. A. S.) ; Portland, Sept. 21, I893.

Nest. In tall tree, 12 to 35 feet from the ground.

Eggs. Usually 4; early in June.

Nesting dates. Earliest record. June 6, 1900, three eggs and one Cowbird's egg (L. B. B.). Latest record. June I7, I893, four eggs (H. W. F. and L. B. B.) ; July Io, I894, one young and one spoiled egg (L. B. B.).

J. H. S. notes that this species and Vireosylva gilva gilva usually migrate together.

Lanivireo solitarius solitarius (Wilson). Blue-headed Vireo; Solitary Vireo.

A common fall and much rarer spring migrant in early May and October; very rare summer resident.

Spring migration. Earliest record. New Haven, May 3, I909, April 20, I892 (Hedges); Portland, April 18, I908, Litchfield, April 25, I905 (E. S. W.). Latest record. New Haven, May 8, I907, May I2, I89I (H. W. F.) ; Portland, May 9, I882; Litchfield, May 26, 1905 (E. S. W.).

Fall migration. Earliest record. New Haven, Sept. 22, 1896; Portland, Sept. 28, I899; Litchfield, Sept. 18, I89 (L. B. W.). Latest record. New Haven, Oct. I8, I888, Oct. 23, I906 (A. A. S.) ; Portland, Oct. I9, I892.

Nest. In young tree or bush, from 5 to ro feet from the ground.

Eggs. Usually 4; late in May and early in June.

Nesting records. Eastford, May 31, I880, four young; June 6, I885, two eggs and one Cowbird's egg; May 14, I886, building, May 27, four eggs; May 27, 28, I886, nests ; June IO, I886, nest, birds hatched and flown away (C. M. Jones). ${ }^{1}$ Norfolk, June 23, I893, four fresh eggs (W. E. T., in coll. of J. H. 
S.). Bethel, June 9, I895, nest with four eggs (Hamlin). Millington, May 30, I899, nest with four eggs (J. H. S.). West Simsbury, June 8, I894, nest with four eggs (Case). ${ }^{1}$ Litchfield, late in June, I907, male in full song (H. K. J. and E. S. W.) ; shot, July I, 1907 (E. S. W.)

Vireo griseus griseus (Boddaert). White-eyed Vireo.

A common summer resident in the southern part of the state from May until August; rarely breeds in Litchfield County.

Earliest record. New Haven, April 30, I885; Portland, May 4, I892.

Latest record. New Haven, Sept. I4, I886; Sept. 20, I906, 1907 (A. A. S.) ; Portland, Sept. 15, 1877.

Sept. 29, I890, May 25, I897, May I7, I905, and July I2, I906, are the only records from Litchfield (L. B. W. and E. S. W.) ; Lake Waramaug, June IO, I900, one seen (L. B. B.).

Nest. Usually in a dense bush or thicket, from $I \frac{1}{2}$ to $2 \frac{1}{2}$ feet from the ground.

Eggs. Commonly 4; early in June.

Nesting dates. Earliest record. May 26, 1887, four eggs (H. W. F.). Latest record. June $2 \mathrm{I}$, 1888, four eggs $(\mathrm{H} . \mathrm{W}$. F.) ; July 2, 1907, half-grown young (A. A. S.).

A set of unspotted eggs has been found near Bridgeport by J. C. A. M., and a single similar egg in a nest containing young at New Haven by L. B. B.

This bird has been heard singing its ludicrous song as late as Aug. I5 (I904) by L. B. B.

Family MNIOTILTIDE. Wood Warblers.

Mniotilta varia (Linnæus). Black and White Warbler.

A common summer resident from early May until September; most abundant during the migrations in May and September.

Earliest record. New Haven, April 26, I900, 1906, I909, April 20, I907 (Kedzie); Portland, April 23, I909.

Latest record. New Haven, Oct. 4, I901, Oct. 7, I907 (A. A. S.) ; Portland, Oct. 6, I892.

2 Job, The Sport of Bird Study, p. 306. 
Nest. On the ground in woods with considerable undergrowth, though occasionally in the grass of an open field.

Eggs. 4-5; the last of May.

Nesting dates. Earliest record. May 20, 1895, five eggs (H. W. F.). Latest record. June 13,1896 , four eggs (J. H. S.) ; June 16, I884, four young and one Cowbird (Prior). ${ }^{1}$

This warbler has been heard singing as late as July 22 (I904) by $\mathrm{L}$. B. B.

Protonotaria citrea (Boddaert). Prothonotary Warbler.

The only records of this warbler for the state are, New Haven, Nov. 27, I9ri, a young female found dead (W. F. Smith), ${ }^{2}$ and Glastonbury, May 14, I910, one seen plainly (L. W. Ripley).

Helmitheros vermivorus (Gmelin). Worm-eating Warbler.

A tolerably common summer resident along the coast; occurring rarely in the interior as far north as Kent and Portland; from the middle of May until early in August.

Earliest record. New Haven, May 6, I904, May 3, I892 ( $H$. W. F.) ; Portland, May 6, 1896.

Latest record. New Haven, Aug. 22, 1903; Portland, June 18, 1896; Seymour, Sept. 30, I888 (Eames).

Nest. On the ground among dead leaves under some small plant on a hillside in the woods.

Eggs. 3-6; the last of May.

Nesting dates. Earliest record. May 20, 189I, five eggs (Watrous). Latest record. June I9, 1890, five eggs (H. W. F.).

Occurrence. This species was reported as "rare" by Merriam" in New Haven, but since then (1877) has become tolerably common east of the city, though still rare to the west. It has been taken also at East Haven (H. W. F.), Pine Orchard (L. B. B.), Saybrook (J. N. C.), New London (Hill), Stamford (Porter), Bridgeport (Eames) ; inland, at Portland (J. H. S.), Seymour (Eames), Bethel (Judd), Danbury (J. C. A. M.), Kent (H. K. J.), ${ }^{4}$ Suffield (Shores). ${ }^{3}$

$1 O$. and $O ., \mathrm{ix}, 9$, p. 109.

aird-Lore, xiv, 2, p. rog.

- Merriam, Birds of Conn., p. 12.

4 Job, The Sport of Bird Study, p. 306. 
Vermivora pinus (Linnæus). Blue-winged Warbler.

An abundant summer resident of southern Connecticut from early May until August, outnumbering any other warbler with the possible exception of the Oven-bird; rarer farther north, though breeding at Portland and at Lake Waramaug in Litchfield County.

Earliest record. New Haven, May 2, I899, April 30, 1908 (C. H. P.) ; Portland, May 2, 1902.

Latest record. New Haven, Sept. 16, 1904; Portland, Aug. 27, 1910.

Nest. Usually at the base of some small plant, often a goldenrod, where woods and meadow join, but also frequently in a small glade in the woods or smaller opening in brush land.

Eggs. 4-6; the last of May.

Nesting dates. Earliest record. May 20, 1896, five eggs (H. W. F.). Latest record. June 16 , 1899 , four eggs (J. C. A. M.).

Occurrence. From Bridgeport to New Haven the Bluewinged Warbler is a very abundant summer resident, Dr. Eames having seen at Bridgeport fully sixty males in song on May 9, I889; but east of Branford it becomes rare, and has been seldom noticed by L. B. B. at Stony Creek or Guilford. At the mouth of the Connecticut they are again abundant. In the interior of the state they are likewise rather rare except in the spring migration, J. H. S. having noted its occurrence only once after June I3 (Aug. 27, 1910), and having observed only three nests; and E. S. W. having noted it only four times in Litchfield. At Danbury a male was taken April 27, 1908 (J. C. A. M.) ; and it has been seen in Kent in August, 1907 (G. E. Hix), at Lake Waramaug, June 10, 1900, and in Washington, May 30, 1907 (L. B. B.).

This species was found interbreeding with $V$. chrysoptera, at Portland, June $13,1889,{ }^{1}$ and a male said to be mate of a female $V$. chrysoptera was taken with it in Woodbridge, May 23, 1898 (A. H. V., in coll. of L. B. B.).

Males showing an approach to $V$. lazerence $i$ in having much black on lores and auriculars or one or two black feathers on

'Auk, vi, 3, p. 279. 
throat have been taken at New Haven on May 23, I902, June 5, 1905, May 24, 1907, and May I8, 1908 (L. B. B.).

Vermivora chrysoptera (Linnæus.) Golden-winged Warbler.

A rare summer resident in most parts of the state, very local in its distribution; a regular summer resident in small numbers at Portland.

Earliest record. New Haven, May II, I904, I905, May 7, I895 (H. W. F.) ; Portland, May 3, I896; Litchfield, May 7, I905 (E. S. W.). Average date of arrival at Portland for thirty-three years, May 14.

Latest record. New Haven, May I2, I894, May 23, I898 (A. H. V.) ; Portland, June 22, I894; Litchfield, July I2, 1906 (E. S. W.) ; Suffield, July 7, I876 (Shores) ; 1 New Haven, Aug. 24, 1912 (L. B. B.).

Occurrence. Bethel, breeding (Stetson, Judd, and Hamlin); Stratford (Eames); New Haven (Hedges, H. W. F., A. H. V., E. S. W., L. B. B.) ; Litchfield (E. S. W.) ; Danbury, breeding (J. C. A. M.) ; Kent (Job) ; Portland, breeding (J. H. S.). It has not been found at New London by Hill, nor at East Hartford by W. E. T., nor at Saybrook by J. N. C., though J. H. S. found one at Saybrook, May 30, I877.

Nest. On the ground in brush land near a swamp.

Eggs. Usually 4 or 5 ; the last of May.

Nesting dates. Earliest record. May 29, 1895, five eggs (Hamlin). Latest record. June 2I, I894, four eggs (J. H. S.).

A nest containing five young with the male parent of this species and the female $V$. pinus was found at Bethel, June II, 1905. June 16 , the young had left the nest; but one was caught which had an olive-green back and yellow throat, breast, and lower parts, showing no black on throat or through eye (J. C. A. M. and R. C. Judd).

Vermivora rubricapilla rubricapilla (Wilson). Nashville Warbler.

A common spring and fall migrant in May and September; breeds in small numbers throughout the state, but more frequently in the northern part. 
Spring migration. Earliest record. New Haven, April 30, 1908; Portland, May 3, 1899. Latest record. New Haven, May 23, I898, May 3I, I907 (A. A. S.) ; Portland, May 30, I894, 1905.

Fall migration. Earliest record. New Haven, Sept. I4, I905; Portland, Sept. 27, I893. Latest record. New Haven, Oct. 9, 1907; Portland, Sept. 27, 1893.

Occurrence. Deep River, two nests (H. W. F.) ; New Haven, three nests (H. W. F.), one nest (L. B. B.) ; Bridgeport, one nest (Beers and Canfield) ; Seymour, breeds somewhat commonly, five or six pairs breeding regularly each year ${ }^{1}$ (Eames); Kent,

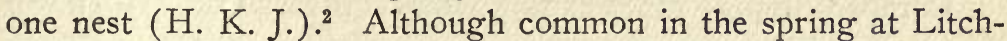
field (L. B. W. and E. S. W.) and at Portland (J. H. S.), no nests have been found at the former place and but one at the latter (June 4 , I889, four young, J. H. S.).

Nest. On the ground, usually just within the edge of the woods.

Eggs. 4-5; the last of May.

Nesting dates. Earliest record. May 30, 1890, five eggs (H. W. F.). Latest record. June 8, I888, five eggs (E. H. E.).

Vermivora celata celata (Say). Orange-crowned Warbler.

A rare straggler from the West during the migrations.

Connecticut records. May 8, I888, East Hartford, male shot, in company with Nashville Warblers (W. E. T.) $;^{3}$ Nov. II, 1893, Stamford, female (Porter); Oct. I, 1906, New Haven, male taken (L. B. B.) ; Oct. 8, 1906, New Haven, young male taken (E. S. W.) ; Oct. 6, I9I I, New Haven, one seen (L. B. B.).

Vermivora peregrina (Wilson). Tennessee Warbler.

A rare spring and fall migrant in May and September.

Spring records. June 8, I875, Suffield, one shot (Shores) $;^{4}$ May 24, I876 (Osborne), May 26, I876 (Bragg), New Haven ; May, 1876, Deep River (H. W. F.) ; May 26, 1888, Seymour (Eames); May 26, I888, New Haven (H. W. F.); May 24, I889, Bridgeport (Eames) ; May 20, I891, New Haven (Webb); May 20, 1892, three, Stamford (Porter); May 23, 1892, East

1 A $u k$, x, r, p. 90 .

2 Job, The Sport of Bird Study, p. 307.

8 Auk, v, 3, p. 323.

- Merriam, Birds of Conn., p. I4. 
Hartford (W. E. T.) ; spring, I894, New Haven (W. C. Morgan) ; May I7, I899, Portland (S. R.) ; May 16, I900, Portland (J.H.S.) ; May 19-27, 1905, Litchfield, tolerably common, several being secured (E. S. W.) ; June 3, I907, Kent (H. K. J.) ;1 May I5-17, I909, Portland (J. H. S.); May 23, I9ro, Portland (J. H. S.):

Fall records. Sept. 24, I887, New Haven (H. W. F.) ; Sept. I5, I892, I896, Litchfield (E. S. W.) ; Oct. 5, 1905, Sept. 8, Oct. 8, 1906, Oct. 9, I907, New Haven (L. B. B.).

Compsothlypis americana usneæ Brewster. Northern Parula Warbler.

A common spring and fall migrant in May and September, breeding wherever it finds trees covered with Usnea.

Spring migration. Earliest record. New Haven, April 29, 1882, April 28, I888 (L. B. W.), I902 (A. A. S.) ; Portland, May I, 1882. Latest record. New Haven, May 21, I900, I902; Portland, May 30, I904.

Fall migration. Earliest record. New Haven, Sept. I, I903, Aug. 19, 1906 (A. A. S.) ; Portland, Sept. 21, 1893. Latest. record. New Haven, Oct. 14, I907; Portland, Oct. 18, I899.

Winter records. Dec. I4, 1877, Deep River (H. W. F.); Nov. 28, Ig0I, New Haven, found dead after a severe storm by Prof. Reynolds (identified by L. C. S.).

Nest. Built in and of the Usnea, generally growing on cedars in the woods, also in swamp oaks, maples, hornbeams, etc., covered with Usnea; 3 to 20 feet from the ground.

Eggs. $3-8$; usually 3 or 4 ; early in June.

Nesting dates. Earliest record. May 18, I894, two eggs (L. B. B.). Latest record. June 29, I886, four eggs (C. L. R.). Of 30 nests recorded by C. L. R. ${ }^{2}$ between $\mathrm{I} 88 \mathrm{I}$ and $\mathrm{I} 887,25$ were found between June $I$ and 12 . The number of eggs in these 30 nests was as follows: 2 nests with 2 eggs, 7 nests with 3 eggs, I8 nests with 4 eggs, I nest with 5 eggs (May 3I, I887), I nest with 7 eggs (June I2, I886), and I nest with 8 eggs (June I2, I890).8

${ }^{1} \mathrm{Job}$, The Sport of Bird Study, p. 307.

$2 O$. and $O$., xiii, 1 , pp. 1.5 .

S 0 . and $0 ., x v i, 4$, p. 60 . 
These Usnea-covered trees have decreasd greatly near New Haven in the past twenty years, and with them have gone the Parula Warblers as summer residents.

Dendroica tigrina (Gmelin). Cape May Warbler.

A very rare spring and fall migrant.

Connecticut records. Spring, 1876, Suffield, not uncommon (Shores) ;1 May 13, 1876, Portland, two adult males seen in the garden, one shot (J.H. S.) ; May 23, 1882, Lake Whitney, Hamden, male taken (L. B. B.) ; May 4, I887, East Hartford, male taken (C. C. H.) ; Aug. 28, r889, Bridgeport, one taken (W. H. Lucas) ;' Sept. I4, I890, East Hartford, one seen (W. E. T.) ; May I3, I89I, East Hartford, male shot (W. E. T.) ; May 7, I900, Kent, male taken (H. K. J.) ; spring, I900, Saybrook, one taken and another seen (J. N. C.) ; May 8, 1905, Litchfield, male secured (E. S. W.) ; May 10, 1907, New Haven, one seen (A. A. S.) ; May 12, I909, Cromwell, one picked up dead (in coll. of J. H. S.).

Dendroica æstiva æstiva (Gmelin). Yellow Warbler.

A common summer resident from May until August, frequenting the alders and willows along the streams.

Earliest record. New Haven, April 30, I888, I894, I908, April 29, 1902 (A. A. S.) ; Portland, April 29, I88I, 1902, 1908.

Latest record. New Haven, Sept. 25, 1900, Nov. 7, 1907 (A. A. S.) ; Portland, Sept. 23, I893.

Nest. In a bush or sapling in a swampy thicket, or less commonly in dry woods. Of 86 nests recorded by J. H. S., 1905-9, the distribution was as follows: 48 in elder; 7 in willow; 6 in alder; 2 each in ash, apple, and elm; I each in wild cherry, buttonwood, poplar, pear, and clematis; and 4 in small bushes. Height from ground varied from 3 to 30 feet, usually 3 to 6

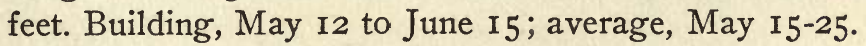

Eggs. 3-5; last of May.

Nesting dates. Earliest record. May 22, 1899, four eggs (J. H. H.). Latest record. June 30, 1895, three eggs (J. C. A. M.).

1 Merriam, Birds of Conn., p. 17.

20 . and $O$., xiv, 10, p. 160 . 
Double nests. Nests with a double bottom built over an intruding Cowbird's egg, found June 30 , 1895, and May 27, 1900 (J. C. A. M.) ; June, 1893 or 1894 (Porter) ; June 2, I898 (L. B. B.).

Dendroica cærulescens cærulescens (Gmelin). Blackthroated Blue Warbler.

A common spring and autumn migrant in May and September; breeds tolerably commonly in Litchfield County at least as far south as Warren.

Spring migration. Earliest record. New Haven, May 5, I894, April 30, I908 (C. H. Pangburn) ; Portland, May 4, I896; Hartford, April 29, I89ı. ${ }^{1}$ Latest record. New Haven, May 28, I907, May 29, 1907 (A. A. S.) ; Portland, May 26, 1894.

Fall migration. Earliest record. New Haven, Sept. II, I902, I903; Portland, Sept. 23, I893. Latest record. New Haven, Oct. II, I906, Oct. I7, I888 (H. W. F.) ; Portland, Oct. 9, I883.

Nest. Just off the ground in thicket, usually of Kalmia; in woods.

Eggs. 3-5; early in June.

Breeding records. June $8, I_{3}, I_{874}$, two nests, and June 7 , I88I, four eggs, Eastford (C. M. Jones) ;2 June 8, I900, Kent, nest with four eggs, female secured (L. B. B.) ; June 7, 1905, nest with five eggs, June IO, I905, three eggs, Litchfield (E. S. W.).

The authors found this species tolerably common in Salisbury between June I6 and 20, I904, frequenting wooded hillsides, overgrown with Kalmia.

Dendroica coronata (Linnæus). Myrtle Warbler.

A common spring and fall migrant in April, October, and November; a tolerably regular winter resident, especially near the coast.

Spring migration. Earliest record. New Haven, March I5, I894; Portland, March II, I882. Latest record. New Haven, May 18, 1884, May 21, 1905 (A. A. S.) ; Portland, May 22, I905; Litchfield, May 24, 1905 (E. S. W.).

2 Merriam, Birds of Conn., p. 15. O. and O., vi, 7, pp. 49-50. 
Fall migration. Earliest record. New Haven, Sept. 21, I903; Portland, Sept. 21, 1892, I893; Litchfield, Sept. I4, I905 (E. S. W.). Latest record. New Haven, Nov. 25, I903; Portland, Nov. I, I89o.

Winter records. New Haven or Guilford, Jan. 5, Feb. 8, 22, Dec. I2, 28, I882, Jan. I, I883, Feb. I7 (?), I886, Jan. 2, I894, Jan. 22, I896, Jan. I7, Feb. I I, I898, Jan. I6, I899, Jan. 24, Dec. I2, I900, Jan. I5, I902, Dec. 18, I903, Feb. 27, 1904, Jan. 24, 1906 (L. B. B.) ; Portland, Dec. I5, I882, Jan. 22, I884, Dec. 29, 1892, Feb. 8, 1896, Feb. 23, I903 (J. H. S.). Other records: Jan. I, 1883, Portland (C. H. N.) ; Jan. 29, 1905, New Haven (Stetson).

Dendroica magnolia (Wilson). Magnolia Warbler.

A common spring, and somewhat less common fall, migrant, in May and September; may breed in Litchfield County.

Spring migration. Earliest record. New Haven, May 7, I888, May 3, I886 (Webb) ; Portland, May 6, I896. Latest record. New Haven, May 26, 1882, I894, May 29, I907 (A. A. S.) ; Portland, May 29, I907, I909; Litchfield, June 8, I89I (E. S. W.) ; Salisbury, early in July, Igo6 (?). (H. K. J.).

Fall migration. Earliest record. New Haven, Aug. I4, Ig03; Portland, Sept. 21, I893. Latest record. New Haven, Oct. 4, I90I; Portland, Sept. 28, 1892.

Partial albino. May I7, I888, Seymour, a male with the entire top of the head, hind neck, and a broad eye ring white (Eames, in coll. of Beers).

Dendroica cerulea (Wilson). Cerulean Warbler.

A straggler to the southern border of the state; possibly a very rare summer resident.

Connecticut records: April, I84I, Stratford (Linsley) ;2 June I2, 1875, Suffield, male taken (Shores) ; May 10, 1888, Seymour, a female taken in a flock of Parulas (Eames) ; May 12, 1900, Bridgeport, male taken (Beers, the two latter being in the collection of Beers).

$1 O$. and $O$., viii, 4 , p. 32.

2 Merriam, Birds of Conn., pp. 15-16.

3 Bull. Nuttall Ornith. Club, ii, 1, p. 21; recorded also by Merriam as above.

$4 A u k$, v, 4, pp. 431-2. 
Dendroica pensylvanica (Linnæus). Chestnut-sided Warbler.

A common summer resident from May until August; breeding more abundantly in the northern part of the state.

Earliest record. New Haven, May 2, I899; April 30, I908 (C. H. P.) ; Portland, April 28, I908.

Latest record. New Haven, Sept. I4, I895, Sept. 24, I887 (H. W. F.) ; Portland, Sept. 5, 1892.

Nest. In a small bush, usually in a brush lot, occasionally in the woods; I-4 feet from the ground.

Eggs. 2-4; early in June.

Nesting dates. Earliest record. May 23, 1896, four eggs (H. W. B.). Latest record. June 24, 1895, three eggs and one Cowbird's egg (Hamlin); July 22, I904, young just out of the nest (L. B. B.).

This species has been found occupying a deserted Red-eyed Vireo's nest, the only part it had constructed being the lining of hair (Hamlin, June 22, 1895). A nest containing four eggs, and one of the Cowbird half buried in the bottom, was found, May 3I, I899 (J. C. A. M.).

Heard singing as late as July Io (1888), by Eames.

A male taken in Litchfield, Aug. I7, I892, by E. S. W. has a very slender bill, the maxilla being .5 inch long, and the mandible slightly shorter with a scoop-shaped tip.

Dendroica castanea (Wilson). Bay-breasted Warbler.

Usually a rare spring migrant and still rarer in the fall; occasionally common for a few days in May.

Spring migration. Earliest record. New Haven, May Io, 1900 ; Portland, May 12, 1905. Latest record. New Haven, June 6, I882; Portland, May 26, I882.

Fall records. Sept. 30, Oct. I7, I876 (Osborne) ; Sept. 25, 1890, Sept. 18, 1893, Portland (J. H. S.) ; Sept. 16, Oct. 5, I887, East Hartford (W. E. T.) ; Sept. 26, I893, Stamford (Porter); Sept. 6, I3, I905, Litchfield (E. S. W.) ; Sept. 27, I9I1, New Haven (L. B. B.).

Spring occurrence. New Haven, I882 (common), I884, I886 (Webb), I892 (Flint), I900 (common), I902, 1905, 1906, 1907 
(A. A. S.), I909; Stamford, I888 (L. B. B.), I902, I905 (Porter) ; Seymour, I888 (Eames); Bridgeport, I892 (Eames); Milford, 1893 (Eames); Portland, I874, 1875, 1876, 1882, 1892, I896, 1898, 1899, 1900, 1902, 1905, 1907, 1908, 1909. J. N. C. wrote in 1900 that in all his collecting he had only seen or taken two Bay-breasted Warblers at Saybrook.

Dendroica striata (J. R. Forster). Black-poll Warbler.

An abundant spring and fall migrant in the last of May and in September and October; their presence in the spring usually indicating the close of the warbler migration.

Spring migration. Earliest record. New Haven, May I3, 1904, April 29, 1908 (Pangburn) ; Portland, May 8, I880. Latest record. New Haven, June 9, I907, June I6, I907 (A. A. S. and Barnum); Portland, June I7, 1907.

Fall migration. Earliest record. New Haven, Sept. 8, I902; Portland, Sept. 14, 1908; East Hartford, Sept. I, 1887, 1890 (W. E. T.); Litchfield, Sept. 7, 1905 (H. Sanford). Latest record. New Haven, Oct. 25, I906; Portland, Oct. 25, 1887.

Oct. 30, I906, New Haven, a pensioner was taken by L. B. B.

Dendroica fusca (Müller). Blackburnian Warbler.

A tolerably common spring and much rarer fall migrant in May and September; a few spending the summer in the pine groves of the northern part of Litchfield County, and doubtless breeding there.

Spring migration. Earliest record. New Haven, May 4, 1900, April 29, I9I I (A. W. H.); April 30, I908 (Pangburn); Portland, May 6, I891, I896. Latest record. New Haven, May 26, I900; May 30, 1907 (Moore); Portland, May 30, 1882.

Fall migration. Earliest record. New Haven, Sept. 13, 1905; Portland, Sept. 5, I892 ; Stamford, Aug. 30, Sept. 4, I893 (Porter) ; Litchfield, Aug. 29, 1892 (E. S. W.). Latest record. New Haven, Oct. 2, 1888 (H. W. F.) ; Portland, Sept. 28, I875 ; Litchfield, Sept. I3, I905 (E. S. W.).

Summer records. July, 1873, Lyme, a female taken (J. G. Ely) $;^{2}$ June 25, I879, Cornwall, male and female taken (Woolsey, in Peabody Museum); June 19, 20, 1904, Salisbury, two

1 Merriam, Birds of Conn., p. 16. 
breeding males taken (J. H. S. and L. B. B.) ; June 16, 21, 24, 29, I905, Litchfield (E. S. W.).

Dendroica virens (Gmelin). Black-throated Green Warbler.

A common summer resident of the hemlock groves throughout the state from May until October; most abundant during the migration in May and September.

Earliest record. New Haven, April 21, I886; Portland, April $27,1886$.

Latest record. New Haven, Oct. 20, 1908; Nov. 7, I907 (A: A. S.) ; Portland, Oct. 2I, 1890.

Nest. On the horizontal limb of a hemlock, less frequently in a birch or cedar; 3 to 30 feet from the ground.

Eggs. $4-5$; the last of May.

Nesting dates. Earliest record. May 2I, I890, four eggs (H. W. F.). Latest record. June 20, I894, four eggs (J. H. S.).

Dendroica vigorsi (Audubon). Pine Warbler.

A rather rare migrant, chiefly in April, and still rarer summer resident.

Spring migration. Earliest record. New Haven, April Io, 1890, March 30, I907 (A. A. S.) ; Portland, April 2, I882, Seymour, April 3, 1885 (Eames). Latest record. New Haven, May 3, I882, May 12, I880 (Woolsey); Portland, April 28, I90r.

Fall records. East Hartford, Sept. 26, Oct. 5, 1885, Sept. 9, Oct. 5, I887 (W. E. T.) ; Portland, Sept. 21, Oct. 5, I892; New Haven, Oct. IO, 1893 (L. B. B.), Oct. 4, I906 (E. S. W.), Oct. 8-23, I906 (?) (A. A. S.) ; Litchfield, Oct. 8, 1905 (H. Sanford, by E. S. W.).

Breeding records. July 4, I893, East Haven, nest with young in a pine about 20 feet from the ground (H. W. F.) ; May 24, 1906, Windsor, a few evidently breeding (E. S. W.); June I, 1909, East Haven, nest with three eggs in pitch pine (L. B. B.).

Dendroica palmarum palmarum (Gmelin). Palm Warbler.

A rare but probably regular fall migrant, the latter part of September.

Fall records. New Haven, Sept. I8, I878, male taken (Woolsey, in Peabody Museum), Oct. 7, 1905, two (E. S. W.), Sept. 24, I895, male, Oct. I, I895, male, Sept. 19, I903, female, Sept. 
26, I905, two, Oct. 5, I905, one female, Oct. 9, I906, Sept. 26, 1907 (L. B. B.) ; Windsor, Sept. 4, I893, one young taken; Portland, Sept. 7, I893, one shot in garden of J. H. S. by S. R.; Branford, Sept. I5, 1906, two (L. B. B.) ; East Haven, Oct. 5, 1907 (L. B. B.).

Spring record. May 5, I888, Stamford, female taken (Hoyt).

Dendroica palmarum hypochrysea Ridgway. Yellow Palm Warbler.

A common spring and fall migrant in April and October; possibly occasionally wintering.

Spring migration. Earliest record. New Haven, April Io, I889, March 24, I890 (L. B. W.) ; Portland, April 4, I9Io. Latest record. New Haven, May I3, I882, May I4, I907 (A. A. S.); Portland, May 8, I893.

Fall migration. Earliest record. New Haven, Sept. 26, I901, I907; Portland, Sept. 29, I893; Litchfield, Sept. 22, I898 (E. S. W.). Latest record. New Haven, Oct. 30, 1907, Nov. 12, 1892 (H. W. F.) ; Portland, Oct. 3I, 1908.

Winter record. Dec. $25, \mathrm{I} 887$, Woodmont, one taken (R. D. Camp).

\section{Dendroica discolor (Vieillot). Prairie Warbler.}

A common summer resident of the southern part of the state from May until July; less common farther north.

Earliest record. New Haven, May 2, 1882, I899, April 27, 1907 (A. A. S.) ; Portland, April 27, I888.

Latest record. New Haven, Oct. I7, I904; Portland, Sept. 2I, I892.

Nest. In a small shrub, often a birch or bayberry, in a thicket, $I / 2$ to 3 feet from the ground.

Eggs. 3-5; the last of May.

Nesting dates. Earliest record. May 27, 1894, four eggs and one Cowbird's egg (Morgan and L. B. B.). Latest record. June 25, r888, four eggs (Eames).

Dr. Eames found it breeding commonly in Seymour in hazel bushes, and has heard it singing as late as July Io (I888). It is very rare in Stamford (Hoyt and Porter). Mr. E. S. Woodruff found a few at Rainbow, Windsor, May 24, 1906. 
Seiurus aurocapillus (Linnæus). Ovenbird.

An abundant summer resident of woodland from May until September.

Earliest record. New Haven, April 27, I907, April 26, 1902 (A. A. S.) ; Portland, May 2, 1902, 1908; Hartford, April 26, 1893. ${ }^{1}$

Latest record. New Haven, Oct. 9, I894; Portland, Sept. 28, rgor.

Nest. On the ground in the woods, covered; usually composed of leaves, strips of bark and vines, and weeds, and lined with fine grass and hair.

Eggs. 2-6, usually 3-5; the last of May.

Nesting dates. Earliest record. May 20, 1886, four eggs (J. H. S.) ; May 20, I895, five eggs. (Beers). Latest record. July Io, I900, three eggs (L. B. B.).

A set of six eggs was collected near New Haven, May 30, I89I, by H. W. F.; a set of two eggs watched from May 3I to June 5, I884, by Hamlin, ${ }^{2}$ and another set of two incubated eggs watched from June I to June 5,1896 , by L. B. B. ; a nest with two infertile eggs and five young birds was found June 16,1883 , by L. B. B.

This species is much persecuted by the Cowbirds, II out of 30 nests examined by L. B. B. containing eggs of this pest.

The Ovenbird has been heard singing as late as July 22 (I904) by L. B. B.

Seiurus noveboracensis noveboracensis (Gmelin). WaterThrush.

A common migrant in May, August, and early September, frequenting the swamps and sluggish watercourses.

Spring migration. Earliest record. New Haven, May 6, 1899, May 2, I888 (H. W. F.), May 2, 1906 (A. A. S.) ; Portland, April 27, 1908; Litchfield, May I, 1905 (E. S. W.). Latest record, New Haven, May 29, I907, May 31, I907 (A. A. S.) ; Portland, May 30, I905; Litchfield, June 3, I905 (E. S. W.).

Fall migration. Earliest record. New Haven, Aug. 3, I898; Portland, Aug. I7, I886. Latest record. New Haven, Oct. 6,

20 . and 0. , xvii, 7, p. 103 . 
I895; Portland, Oct. 3, I890, I893, I894; Litchfield, Sept. 23, 1905 (E. S. W.).

Seiurus noveboracensis notabilis Ridgway. Grinnell's Water-Thrush.

A rare visitor during migrations.

Connecticut records. Sept. 7, 1904, Hamden, young female; Sept. 21, I904, East Haven, young male; May 20, 1905, Orange, adult male; Aug. 25, Sept. 7, I906, New Haven - all taken by L. B. B.; Aug. 29, I907, Branford, one found dead (L. C. S., in coll. of L. B. B.).

Seiurus motacilla (Vieillot). Louisiana Water-Thrush.

A tolerably common summer resident from April until July, breeding throughout the state but most abundant near Saybrook.

Earliest record. New Haven, April Io, I896; Portland, April I3, I892.

Latest record. New Haven, Aug. I, I904.

Unusual record. Feb. I5, I882, Deep River, one shot (H. W. F.). ${ }^{1}$

This species is rare in Litchfield County, but we have the following records: July 3I, Aug. I, 5, 9, I893, Litchfield (E. S. W.) ; June I3, I900, Warren, adults with young seen (L. B. B.) ; June 20, I904, Salisbury, an adult (J. H. S. and L. B. B.); June I4, I905, June 28, 1906, Mt. Tom, Litchfield County (E. S. W.).

Nest. In an upturned root, a mossy bank, or under the edge of the cut bank of a stream, usually within I to 5 feet of the water.

Eggs. 4-6; the middle of May.

Nesting dates. Earliest record. May 6, I902, three eggs ( J. C. A. M.) ; May 9, 1900, six eggs (J. H. H.). Latest record. June ro, 1894, four eggs (L. B. B.).

Heard singing as late as July 22 (1904) by L. B. B.

Oporornis formosus (Wilson). Kentucky Warbler.

Very rare summer visitant along the southwestern coast.

Connecticut records. May 30, 1888, West Stratford, a male shot (W. H. Lucas) ; July Io, I892, Greenwich, a female seen

$1 O$. and $O .$, vii, 19, p. 147 .

20 . and 0 ., xiv, 4, p. 62 . 
feeding a well-fledged nestling in the swampy woods; later, the same day, the male secured (C. G. Voorhees). ${ }^{1}$

Oporornis agilis (Wilson). Connecticut Warbler.

A tolerably common fall migrant in late September and early October; shy, and frequenting damp young woods with dense undergrowth; unknown in the spring.

Earliest record. New Haven, Sept. 12, I904; Portland, Sept. 7, I899; Litchfield, Sept. I, I893 (E. S. W.) ; East Hartford, Sept. I, I887 (W. E. T.).

Latest record. New Haven, Oct. 8, I909, Oct. I3, I906 (E. S. W.) ; Portland, Oct. I2, I909; Litchfield, Oct. II, I900 (E. S. W.) ; Easton, Oct. 3, Ig08 (H. W. B.).

This warbler is reported by E. S. W. as tolerably common in the fall at Litchfield. L. B. B. has a dozen or so records from New Haven, and J. H. S. an equal number from Portland. At other places it seems to be rather rare, Porter reporting it from Stamford only once (Sept. 28, 1893), Perry and Beers at Bridgeport once (Sept. I5, I904), and Hoyt from Washington once (Oct. 10, I904).

Adult males seem to be very rare, one being taken Sept. 27, I886, by H. W. F., another Sept., I893, by A. H. V. (in coll. of Porter), and one seen Oct. 5, I90I, by L. B. B. Taken at Portland, Sept. 23, 25, Oct. 5, 1893, by W. E. T. (in coll. of J. H. S.).

Oporornis philadelphia (Wilson). Mourning Warbler.

A rare late spring and fall migrant.

Connecticut records. Merriam ${ }^{2}$ records the following: May, 1875, Milford, male and female killed (Grinnell); May I5, I7, I876, New Haven (Osborn); May 24, I876, New Haven, male (Bragg) ; May 25, I876, New Haven, two males (Dayan); May 27, 1876, New Haven, several seen (Merriam); May 25, I877, Savin Rock, New Haven, male (Merriam). Other records are: May 30, I877, Saybrook (J. H. S.) ; May 30, I879, Whitneyville, female (Woolsey, in Peabody Museum) ; May 23, I882, Deep River, male (H. W. F., in Brewster collection); May 8, I885, Litchfield, two seen (L. B. W.) ; Sept. 24, I89I, Litchfield, a female, the only fall record (E. S. W.) ; May 17, I8, I892, New

1 A k,$\quad$ X, I, p. 86.

2 Merriam, Birds of Conn., p. 23. 
Haven, two males (H. W. F.) ; May 26, I892, East Hartford, male taken (W. E. T.) ; May 26, I893, Whitneyville, male seen (L. B. B.) ; May 26, 27, I893, Portland, male taken (J. H. S.) ; May 31, 1898, Hamden, male taken (A. H. V., in coll. of L. B. B.) ; May 21, I900, Kent (H. K. J.) ; June 17, 1907, Portland, adult male seen (J. H. S.).

Geothlypis trichas trichas (Linnæus). Maryland Yellowthroat.

A common summer resident, from May until October.

Earliest record. New Haven, May 2, 1899, 1908, May I, I902, 1907 (A. A. S.) ; Portland, April 29, I908.

Latest record. New Haven, Nov. 3, 1883; Portland, Nov. 7, I884.

Nest. On the ground under a plant, or a few inches from the ground in a tussock of grass or a skunk cabbage in a wooded swamp, or in a bush in a thicket.

Eggs. 4-5; the last of May.

Nesting dates. Earliest record. May 22, I888, five eggs (C. L. R.). 1 Latest record. June 29, I905, four eggs (E. S. W.). This species has been heard singing as late as Aug. I (I904), by L. B. B.

A young male with bill twisted like that of a Crossbill taken in East Haven, Oct. 4, I905 (L. B. B.).

Icteria virens virens (Linnæus). Yellow-breasted Chat.

A common summer resident from May until July, breeding in brush lots throughout the state, but most abundantly in the southern portion.

Earliest record. New Haven, May 2, I899, I908; Portland, May 6, 1896.

Latest record. New Haven, Aug. 17, I894, Sept. 21, I904 (?).

Unusual records. Oct. 3, 1896, New Haven, one just shot seen in a gun store (L. B. B.) ; Dec. 24, I9II, Jan. I, I9I2, South Norwalk (W. F. Smith). ${ }^{2}$

Nest. In a thick bush in brush lot, $1 \frac{1 / 2}{2}$ to 7 feet from the ground.

Eggs. 2-5, usually 4; the last of May.

1O. and $O$., ii, $\mathrm{x}, \mathrm{p} . \mathrm{x}$.

2 Bird-Lore, xiv, 2, p. 114 . 
Nesting dates. Earliest record. May 22, I896, four eggs (L. B. B.). Latest record. July 7, 1888, four eggs (Eames).

Unusual sets. New Haven, June 9, I899, set of two exceedingly small eggs (H. W. F.) ; Hamden, May 27, 1896, five eggs and two Cowbirds' eggs (L. B. B.).

Wilsonia citrina (Boddaert). Hooded Warbler.

A tolerably common summer resident of the southern part of the state from May to July; very rare inland.

Earliest record. New Haven, May 8, I894; East Haven, May 4, I886 (L. C. S.) ; Saybrook, May 2 (J. N. C.). ${ }^{1}$

Latest record. New Haven, July 22, 1904, Westville, Sept. 20, 1897 (A. H. V., in coll. of L. B. B.).

Inland records. Suffield (E. I. Shores);2 Beacon Falls and Newtown (Eames); Winchester, I900, nest with four eggs (Williams). ${ }^{3}$

Nest. Usually in the fork of a small Kalmia growing in the woods, I-2 feet from the ground; composed of dry leaves, grapevine bark, woolly and cottony material, and lined with fine new grass, grape-vine bark, root fibers, or horse-hair.

Eggs. 2-5, usually 4 ; the beginning of June.

Nesting dates. Earliest record. May 25, I880, four eggs (J. N. C. .). Latest record. June 24, I893, four eggs (H. W. F.).

Breeding localities. This species has been found breeding in Stamford (Porter), Bridgeport (Beers and J. C. A. M.), up the Housatonic as far as Beacon Falls and Newtown (Eames), near New Haven (H. W. F., A. H. V., L. B. B.), Saybrook (abundant, J. N. C.), Deep River (H. W. F., Watrous), New London (Hill).

This species frequents the dense Kalmia thickets of wooded hillsides. On account of its shy habits it is not as frequently seen as heard. The Hooded Warbler has been heard singing as late as July 22 (I904) by L. B. B.

Wilsonia pusilla pusilla (Wilson). Wilson's Warbler.

A spring and fall migrant in May and September; usually rather rare, and most often seen in the spring.

1O. and 0. , vi, 2, p. 9.

2 Merriam, Birds of Conn., p. 25.

Job, The Sport of Bird Study, p. 309. 
Spring migration. Earliest record. New Haven, May II, 1893, I900; Portland, May 8, I894, I905. Latest record. New Haven, May 22, 1893, 1907, June 3, 1907 (A. A. S.) ; Portland, June I, 1907.

Fall migration. Earliest record. New Haven, Aug. 27, 1907. Latest record. New Haven, Sept. 22, 1904; Portland, Sept. 27, I893.

This bird frequents chiefly thick shrubbery in its passage through the state.

Wilsonia canadensis (Linnæus). Canada Warbler.

A common late spring migrant in May, and much rarer late summer migrant in August; undoubtedly breeds more or less regularly in the northwestern part of the state, although few nests have been taken.

Spring migration. Earliest record. New Haven, May 8, I894; Portland, May I, 1905. Latest record. New Haven, June I, 1898, 1907, June 3, 1907 (A. A. S.) ; Portland, June 10, 1907; Milford, June 3, 1900 (J. C. A. M.).

Fall migration. Earliest record. New Haven, Aug. 12, 1904. Latest record. New Haven, Sept. I, 1903; Portland, Sept. I, I892 ; Litchfield, Sept. 9, 1892 (E. S. W.); East Hartford, Sept. I6, 1885 (W. E. T.).

Summer records. June 15, 1885, June 9, I891, Aug. 2, 1893, June 13, I4, 1905, Litchfield (L. B. W. and E. S. W.) ; June 15, I894, near New Haven, a male with a female and young seen (A. H. V., the male taken by L. B. B.) ; July 3 , 1896, Norfolk, young taken by W. E. T. (in coll. of J. H. S.) ; June 8, 1900, Kent (L. B. B.) ; June II, I900, Warren (L. B. B.) ; June I2, I900, Romford (L. B. B.) ; June 18,20 , 1904 , Salisbury (J. H. S. and L. B. B.) ; early July, 1906, Salisbury (H. K. J.).

Nest record. May 30,1889 , Northford, nest containing five eggs in a raspberry bush in a pasture, male identified while on the nest (A. M. Linsley). ${ }^{1}$

As all of the birds noted above in June kept closely to the locality in which they were first seen as long as they were observed, and as the males taken were certainly breeding birds, this species must be entered as a summer resident in this state. Dur- 
ing this time this warbler frequents secluded ravines or wooded hillsides, with thick undergrowth of Kalmia, and carpeted with dry leaves.

Setophaga ruticilla (Linnæus). Redstart.

A common summer resident from May until September, breeding in somewhat larger numbers in the northern part of the state.

Earliest record. New Haven, April 30, I908; Portland, April 30, 1903 .

Latest record. New Haven, Sept. 29, 1897, Oct. 5, Ig07 (A. A. S.) ; Portland, Sept. $26,1890$.

Nest. Usually in a fork of the trunk of a small deciduous tree, from Io to 20 feet from the ground. Building, May 20, to June I5.

Eggs. 3-5, usually 4; early in June.

Nesting dates. Earliest record. May 20, 1894, five eggs (H. W. F.). Latest record. June 27, 1883, three eggs (Eames).

Young males with the plumage somewhat brighter than the juvenal, with scattered black feathers on the throat, are common in the spring, and also occasionally noted in the fall (Sept. I7, I900, Sept. IO, I904, L. B. B.). L. B. B. is inclined to believe that this is the normal plumage of the male in the second year, and that it is assumed the first fall.

The Redstart has been heard singing as late as Aug. I 5 (I904) by L. B. B.

Family MOTACILLIDÆ. Wagtails.

Anthus rubescens (Tunstall). Pipit.

An abundant fall migrant in October and early November in the salt marshes; much rarer in the spring and in the interior of the state.

Spring migration. Earliest record. New Haven, April 2, I898; Portland, April 8, I909; Stamford, March 26, I894 (Porter). Latest record. New Haven, April 24, I889, May I6, I888 (L. B. W.) ; Portland, May 8, I905; Bridgeport, May 4, I892 (Eames).

Fall migration. Earliest record. New Haven, Sept. 25, I903; Portland, Sept. 27, 1892. Latest record. New Haven, Nov. 9, I903, Nov. 23, 1907 (A. A. S.) ; Portland, Nov. 5, I89o.

Winter records. Samuels recorded that this species "re- 
mained throughout mild winters in southern New England." 1 Dec. I, I883, Dec. 3I, I885, Dec. I2, I889, Guilford (L. B. B.).

Family MIMID Æ. Thrashers, Mockingbirds, etc.

Mimus polyglottos polyglottos (Linnæus). Mockingbird. Very rare visitant.

Connecticut records. Linsley recorded it from Stratford and New Haven ${ }^{2}$; Milford (G. B. Grinnell) ${ }^{2}$; Suffield (Lester) ${ }^{2}$; Saybrook (J. N. C. $)^{2}$; May 30, 1877, near New Haven (Osborne) ${ }^{2}$; Dec. 18, 1882, New Haven (formerly in coll. of L. C. S., seen in flesh by L. B. B.) ; June 20, 1884, Jewett City, nest with five eggs, June 28 , second clutch of three eggs, female shot and identified (Prior) ${ }^{3}$; July 21, I894, West Haven, one reported seen, in the New Haven Journal and Courier; Nov. 2, 1904, New Haven, one flew into greenhouse (J. Y. Stetson, seen by L. B. B.) ; June 9, 1907, Middletown, one seen (Cady); Nov. 30, I910-Feb. 9, I9II, West Hartford, one seen and identified by Mrs. L. A. Cressy; another seen the same winter (St. John) ${ }^{4}$; Feb. 8-April 4, I9I I, Portland, one seen by C. H. N.

The late Frank L. Burr, of the Hartford Times, once told me that about the time of the Civil War a pair of Mockingbirds nested in the meadow north of Avon St., Hartford. There was no question as to the identity of the birds, but the eggs were destroyed. A year or two later a pair had a nest quite near a house on Wethersfield Ave. in the same city, and in the vicinity of Armsmear, the residence of the late Mrs. Samuel Colt. This nest also had eggs which were destroyed. Gurdon Trumbull, the artist and ornithologist of Hartford, now dead, informed me that he remembered distinctly two or three pairs of these birds nesting, about I860, in what was then known as Gillette's Grove, Hartford. He saw the birds and heard them sing. The eggs were taken by Mr. Trumbull and a boy friend, now a well-known actor and playwright. (J. H. S.)

Dumetella carolinensis (Linnæus). Catbird.

An abundant summer resident from May until September; winters accidentally. 
Earliest record. New Haven, April 30, 1908, April 29, 1882 (L. C. S.) ; Portland, April 27, 1908.

Latest record. New Haven, Nov. 2, I904, Nov. 4, I874, I875 (Merriam) ; Portland, Oct. 12, 1909.

Winter records. Jan. 24, I900, Guilford, one taken (A. H. V. and L.B.B.) ; Jan. 4, 1904, Berlin, bird which had spent winter, being fed by people, died of starvation (seen by J. H. S.) ; Dec. 24, I9I I, South Norwalk (W. F. Smith). ${ }^{2}$

Nest. In a thicket, such as in an elder bush or grape-vine, or low willow, or tangle of bushes, 3 to I2 feet from the ground.

Eggs. 2-5, commonly 4; the last of May.

Nesting dates. Earliest record. May 17, 1887, nest with five eggs (J. N. C.). ${ }^{3}$ Latest record. July 26 , I889, nest with three fresh eggs (W. I. C.) ; Aug. 4, I882, two young (L. B. B.).

Unusual nesting records. June 5, I889, nest composed largely of paper (L. B. B.) ; May 20, 1893, nest with five eggs, built inside old Robin's nest (Beers); June 3, 1894, Branford, nest with six eggs (Nichols).

Mr. John Nichols records having seen eggs of this species spotted with red.

Toxostoma rufum (Linnæus). Brown Thrasher.

A common summer resident from May until September; winters accidentally.

Earliest record. New Haven, April 23, 1906, April 21, 1906 (A. A. S. and E. S. W.) ; Portland, March 28, I879, April 20, I9ro.

Latest record. New Haven, Oct. 24, I9II ; Portland, Oct. 20, I890; Branford, Nov. 29, I9I I (John Nichols).

Winter records. Shortly before Feb. 15, 1896, Bethel, collected by E. T. and H. C. Judd (in coll. of H. C. Judd); Jan. I7, Feb. II and 22, 1912, South Norwalk (W. F. Smith). ${ }^{5}$

Nest. Commonly on the ground at the foot of a stump, in a heap of brush, in bushes up to 4 feet from the ground, or very

1 Merriam, Birds of Conn., p. 8.

Bird-Lore, xiv, 2, p. I14.

3 . and O., xii, ro, p. 174 .

4 Oölogist, vi, 12, p. 23 I.

-Bird-Lore, xiv, 2, p. I14. 
rarely higher in a tree, I2 feet from the ground, May 30, 1896 (Camp and L. B. B.).

Eggs. 3-5; the last of May.

Nesting dates. Earliest record. May 12, I894, five eggs (L. B. B.). Latest record. July 8, I882, three eggs (L. B. B.).

The Brown Thrasher has been heard singing as late as Sept. I6 (I904) by L. B. B.

A female with the bill unusually long and slender and the maxilia extending .I9 inch beyond the mandible, taken at New Haven, May 2, I892 (C. F. Hedges, in coll. of L. B. B.).

Family TROGLODYTID瓜. Wrens.

Thryothorus ludovicianus ludovicianus (Latham). Carolina Wren.

A rare resident of the southern border, having apparently appeared, and certainly greatly increased, during the last few years.

Connecticut records. Merriam ${ }^{1}$ gave no records, but said, " it doubtless occurs as a rare summer resident from the South in the Connecticut Valley and along our southern border". Nov. I5, 1878, Saybrook, one taken (J. N. C.) ${ }^{2}$; March 2, I883, Portland, male shot (C. H. N.) ${ }^{3}$; 1884 , Portland, one reported seen by Chas. Lincoln; March 18, I886, East Hartford, male taken (W. E. T.) ${ }^{4}$; fall, I89I, Stamford, two taken (reported by Hoyt); April 8, 1892, Bridgeport, male taken (Eames) ${ }^{5}$; Oct. 23, I894, Stamford, one taken (Hoyt, in coll. of L. B. B.) ; Nov. 30, 1894, Stamford, male (Schaler); April 20, 1895, two seen, June I3, I895, same two and two young seen, near Bridgeport (Eames and Taylor) ${ }^{6}$; Dec. I7, I897, Lyme, one seen (Brockway) $^{7}$; April 7, 1900, Norwalk, pair seen (Smith) ${ }^{8}$; July 15, I90I, Chester, nest with five eggs (Watrous) ${ }^{8}$; winter, I90I-2, Norwalk, pair wintered (Smith) ${ }^{\circ}$, May 2, I902, Norwalk,

1 Merriam, Birds of Conn., p. 11.

2 Bull. Nuttall Ornith. Club, iv, 1, p. 61.

s Bull. Nuttall Ornith. Club, viii, 2, p. 120.

4 Auk, iii, 4, p. 489.

- $A u k, \mathrm{x}, \mathrm{x}, \mathrm{p} .89$.

- $A u k$, xiii, 1, p. 84 .

$7 A u k, \mathrm{xv}, 2$, p. 192.

8 Auk, xix, 1, p. 9 r.

- Bird-Lore, v, 5, pp. 163-4 
nest (Smith) ${ }^{1}$, Sept. II, I902, New Haven, young male taken (L. B. B.) ; Oct. 3I, I902, Guilford, young female taken, another seen, and still another Nov. 4, I903 (L. B. B.) ; 1903, Norwalk, tow pairs nested (Smith) ${ }^{1}$; Nov. 4, I903, Leete's Island, one seen (L. B. B.).

After 1903 records of this species in Connecticut ceased, and it is probable that nearly all of those Wrens perished in the cold winters of $1903-4$ and $1904-5$. In the winter of $1908-9$ the Carolina Wren again appeared in numbers: New Haven, Dec. 25, I908-March 6, I909, two seen on a dozen dates (A. W. H., C. H. P., D. B. P.), May 26, I909, one (L. B. B.) ; Bethel, March I7, I909, one (R. C. Judd) ; Bridgeport, May 9, June I, I909 (H. W. B.) ; Portland, Feb. 22, 23, June II, I2, I8, I909 (J. H. S.) ; Hartford, May 16, I909, one seen (Smith, Powers, and Gabriel). Since then we have no records until Nov. I6-23, I9II, when a male was seen and heard singing at East Hartford by W. E. T. The bird remained and was in full song Aug. 20, I9I2. Westbrook, Aug. 4, I912, nest with two young (Mrs. L. W. Gregg). Probably this Wren still occurs near Stamford, where it was apparently firmly established as early as I895.

Troglodytes aëdon aëdon Vieillot. House Wren.

A tolerably common summer resident of orchards from May to September; not abundant anywhere, and apparently decreasing in numbers.

Earliest record. New Haven, April 26, I909, April 24, I906 (A. A. S.) ; Portland, April I9, I896.

Latest record. New Haven, Oct. I4, I907, Oct. I6, I906 (E. S. W.) ; Portland, Sept. 26, I893; East Hartford, Oct. I6, I887 (W. E. T.).

Nest. In a hollow in a tree, commonly an apple, in a post or a building, occasionally in the deserted nest of a Baltimore Oriole. $^{2}$ Height from ground, 6 to 18 feet.

Eggs $3-8$, the last of May.

Nesting dates. Earliest record. May 23, I884, three eggs (L. B. B.). Latest record. Aug. I2, I900, five eggs (W. R. Nichols). A set of eight eggs was collected in Westville, New Haven, May 30, I894 (H. W. F.).

${ }_{1}$ Bird-Lore, v, 5 , pp. 163.4 .

2 Bird-Lore, i, 5, p. 166 . Oölogist, xiv, 6 , p. 58. 
The spread of the English Sparrows into the farming districts has probably had much to do with the decrease of this species, as they preëmpt all the suitable breeding hollows before the House Wrens arrive. In New Haven, where this Wren formerly bred commonly, even in the center of the city, its song is now seldom heard.

The House Wren has been heard singing as late as Sept. I6 (Ig04) by L. B. B.

Nannus hiemalis hiemalis (Vieillot). Winter Wren.

A tolerably common fall migrant in October, a much rarer winter resident and spring migrant; very rarely breeds in this state.

Fall migration. Earliest record. New Haven, Sept. 18, I903; Portland, Sept. 23, r893. Latest record. New Haven, Nov. 4, r903; Portland, Nov. 27, r889.

Winter records. Dec. I, I879, New Haven (Goodrich, in coll. of L. B. B.) ; Jan. 14, I901, Jan. I5, I902, March 7, I903, Jan. 9, 1905, Guilford (L. B. B.) ; Feb. I, 1877, Feb. 4, I885, March I2, I889, Feb. 22, I890, Feb. 23, I89I, Feb. 22, I899, Dec. 9, I90I, Dec. 2I, I908, Portland (J. H. S.).

Spring records. New Haven, May I5, I889 (L. B. W.), April Io, I889, May 3, I904 (L. B. B.), March 29, April 26, 1907 (A. A. S. and C. H. P.) ; Bridgeport, May 3, I892 (Eames).

Summer record. Sage's Ravine, Salisbury, July 5, 6, 1906, two pairs found (H. K. J.). ${ }^{1}$

One noticed singing as late as Nov. 4 (1903) by L. B. B.

Cistothorus stellaris (Naumann). Short-billed Marsh Wren.

A rare summer resident from June to September; tolerably common in parts of Litchfield County.

Earliest record. New Haven, May 22, I890 (L. B. W.) ; Portland, May 15, 1888.

Latest record. New Haven, Oct. 13, 1906 (H. H. Townsend) ; Portland, Oct. I4, I892.

Distribution. Litchfield, reported fairly common by E. S. W., and eggs found June 8, I89I, and June 27, 1907, and two birds

1 Job, The Sport of Bird Study, p. 3 ro. 
taken by A. H. V., Sept. I5, 1894; Warren, June 9, I2, I900, taken by L. B. B.; Bethel, reported regularly by G. L. Hamlin, eggs taken July Io, I890, by H. C. Judd; Danbury, one pair reported regularly by G. L. Hamlin; New Haven, May 22, I890 (L. B. W.), July I9, I893 (Hedges and H. W. F.), Sept. 25, I895 (H. W. F.), Oct. I3, I906 (Townsend); Portland, fairly regular during the last week of September and first of October from I89o to I899 (Sept. 9, I893, Oct. I4, I892), also May I5, I888, May 23, 1904, and May 16, I910.

Nest. In grass of a shallow fresh-water marsh, from I to 2 feet from the ground.

Eggs. 5-8; the middle of June.

Nesting dates. Earliest record. June 8, I89I, seven eggs (L. B. W. and E. S. W.). Latest record. July Io, I890, eggs (H. C. Judd).

Telmatodytes palustris palustris (Wilson). Long-billed Marsh Wren.

An abundant summer resident of the salt and brackish marshes from May to September.

Earliest record. New Haven, May 5, I896; Portland, May 5, 1906, 1908.

Latest record. New Haven, Nov. 8, Ig04; Portland, Oct. 26, 1887.

Winter records. Nov. 26, 1905, Feb. 24, 1906, March 6, 1906, Quinnipiac Marshes, North Haven (E. S. W.).

Nest. In grass of a marsh, cat-tails, sweet flag, or small bushes, from I to 6 feet from the ground, usually I to 3 feet.

Eggs. 2-6; the middle of June.

Nesting dates. Earliest record. June I, I905, five eggs ( $\mathrm{J}$. H. S.). Latest record. Aug. 24, 1903, two young (L. B. B.).

Unusual eggs. Set of four white eggs, June 24, 1893, Quinnipiac Marshes, North Haven (L. B. B.) ; set of five, same spot, less than Io yards away, July II, $\cdot 1893$; four more, in a nest about 8 feet from the first, July 28, I893; Portland, June 8, I905, set of $\operatorname{six}(\mathrm{J} . \mathrm{H}$. S.).

This species has been heard singing as late as Sept. I8 (I895) and Sept. 26 (1904) by L. B. B. 


\section{Family CERTHIID压. Creepers.}

Certhia familiaris americana Bonaparte. Brown Creeper. A tolerably common winter resident from October to April; most common in October, but wintering regularly in small numbers.

Earliest record. New Haven, Sept. 22, 1903, 1904; Portland, Oct. 2, I893; Litchfield,. Sept. I9, 1906 (E. S. W.).

Latest record. New Haven, May 7, 1888; Portland, April 27, 1907; Danbury, April 28, 1907 (J. C. A. M.) ; East Hartford, May 7, I892 (W. E. T.).

\section{Family SITTID压. Nuthatches.}

Sitta carolinensis carolinensis Latham. White-breasted Nuthatch.

A tolerably common resident, but less common than formerly in southern Connecticut.

Nest. In a hole, at least partially excavated by the birds themselves, in the trunk of a large tree in the woods at from 25 to 30 feet from the ground.

Eggs. 5-9; early in May.

Nesting dates. Earliest record. April 21, 1890, five eggs (J. H. S.). Latest record. May 30, 1877 , six eggs (J. H. S.).

A set of eight eggs taken, May I3, I902 (Hill); a set of nine eggs taken in Jewett City, May I9, I884 (C. E. Prior). ${ }^{1}$

Sitta canadensis Linnæus. Red-breasted Nuthatch.

A common fall and rare spring migrant, and an irregular winter resident; most abundant in October.

Spring migration. Earliest record. New Haven, March 24, I902; Portland, March 14, I893, 1900. Latest record. New Haven, April I, I896, April 27, I888 (L. B. W.) ; Portland, May Io, 1893 .

Fall migration. Earliest record. New Haven, Aug. 27, I903; Portland, Sept. 4, 1908. Latest record. New Haven, Nov. 4, 1903, Nov. 28, 1906 (A. A. S.) ; Portland, Oct. I8, 1888.

Winter records. New Haven, Feb. 22, I894, Feb. Io, Dec. 10, 1896, Jan. 24, Feb. 6, 16, 21, 1900, Jan. 15, Dec. 30, 1902, 
(L. B. B.), Jan. 25, 1907 (E. S. W.) ; Portland, Dec. 9, 30, 1895, Jan. 23-Feb. 22, 1896, Dec. 6-I8, 1899, Feb. I2, I900, Jan. I5, 1902 (J. H. S.).

Breeding records. June $I, 1876$, Winchester, nest with eggs found, the female being shot (in coll. of Williams); June 27 , I896, Norfolk, male, female, and young taken by W. E. T. (in coll. of J. H. S.)

\section{Family PARID压. Titmice.}

Bæolophus bicolor (Linnæus). Tufted Titmouse.

A very rare visitor from the south.

The only Connecticut records are those noted by Merriam:2 Linsley recorded it at New Haven; Feb. 27, I872, one shot, Jan., I874, one seen, Lyme (J. G. Ely); taken near Hartford by Dr. D. Crary.

Penthestes atricapillus atricapillus (Linnæus). Chickadee.

A common resident; keeping in family flocks except in the breeding seasons, and venturing into the cities in the fall and winter.

Nest. In a hole excavated by the birds in a dead stump or limb at from ro inches to 20 feet from the ground. The entrance is often from the top of the stump, and the nest cavity sometimes extends below the ground level.

Eggs. 3-IO; the middle of May.

Nesting dates. Earliest record. May II, I89I, seven eggs (J. N. C.). Latest record. July 2, I893, four eggs (A. H. V. and L. B. B.).

Unusual sets. Set of eight and another of nine reported at Wallingford in 1884 (J. R. M.) ; set of eight taken at Ivoryton, May 28, I895 (G. D. French, in coll. of L. B. B.) ; set of ten found May 30, I904, and set of eight found May 18, 1907, at Portland (J. H. S.).

Penthestes hudsonicus hudsonicus (J. R. Forster). Hudsonian Chickadee.

The only Connecticut record for this species is reported in the Bulletin of the Nuttall Ornith. Club for July, 1876 , and is quoted 
by Merriam:1 "On Nov. 13, I875, Mr. Robert Morris, while shooting in a wooded ravine a few miles from town (New Haven), killed a female Hudsonian Titmouse (Parus Hudsonicus). The specimen is now in the collection of Mr. Thomas Osborne of this city."

Family SYLVIIDA. Warblers, Kinglets, Gnatcatchers.

Subfamily Regulinæ. Kinglets.

Regulus satrapa satrapa Lichtenstein. Golden-crowned Kinglet.

An abundant fall and common spring migrant, and tolerably common winter resident; the majority passing through the state in October and November and again in March and April.

Spring migration. Earliest record. New Haven, March I, 1898; Portland, March 2, I898. Latest record. New Haven, April 28, I906, May II, 1906 (A. A. S.) ; Portland, April 25, I888.

Fall migration. Earliest record. New Haven, Sept. 24, I903; Portland, Oct. 8, I890; Litchfield, Sept. 21, I896 (L. B. W.). Latest record. New Haven, Nov. 22, I904; Portland, Nov. 28, I88I.

Winter records. It has been observed in small numbers near New Haven during most winters by L. B. B., and in Portland during the winters of $1874-5,1877-8,1889-90,1892-3,1899-1900$, I902-3, I9IO-I I, by J. H. S.

Regulus calendula calendula (Linnæus). Ruby-crowned Kinglet.

A common fall and tolerably common spring migrant in October and April; mingling with the Golden-crowned Kinglet.

Spring migration. Earliest record. New Haven, April 7, I888; Portland, April 8, I889. Latest record. New Haven, April 27, 1907, May 14, I907 (A. A. S.) ; Portland, May 6, I89I ; Litchfield, May Io, I905 (E. S. W.).

Fall migration. Earliest record. New Haven, Sept. 22, I904; Portland, Sept. 26, I893. Latest record. New Haven, Oct. 28, I904, Nov. 4, I907 (A. A. S.), Nov. 24 (Merriam) ;2 Portland,

2 Merriam, Birds of Conn., p. 8. 
Oct. 26, I892; Guilford, Nov. 22, 1894, one with slightly injured leg taken (L. B. B.).

A young male with the crown patch orange-buff and the entire plumage more gray even than adults in spring was collected in New Haven, Oct. 28, 1904, by L. B. B.

\section{Subfamily Polioptiline. Gnatcatchers.}

Polioptila cærulea cærulea (Linnæus). Blue-gray Gnatcatcher.

Very rare summer visitant.

Connecticut records. Linsley recorded it from Stratford ; 1874 (male), I876 (female), Wauregan, shot by C. M. Carpenter ; May II, I883, Portland, male shot (in possession of J. W. Lord) ;2 Sept. I, I885, New Haven, young male taken (L. C. S.) ; May 7, I886, East Hartford, female killed (W. E. T.) ; April 6, 1892, Stratford, one heard (Eames). ${ }^{5}$

Family TURDIDE. Thrushes, Solitaires, Stonechats, Bluebirds, etc.

Subfamily Turdinж. Thrushes.

Hylocichla mustelina (Gmelin). Wood Thrush.

A common summer resident throughout the state from May till September; abundant along the southern border.

Earliest record. New Haven, April 26, I900; Portland, April 28, 1902 .

Latest record. New Haven, Oct. 3, I895, I903, Oct. 4, I906 (E. S. W.) ; Portland, Sept. 18, I893.

Nest. In a sapling or tree in the deep woods, $2-25$ feet from the ground. Building, May 10-25.

Eggs. 3-5; the last of May or first week in June.

Nesting dates. Earliest record. May 16, 1900, four eggs (Hill). Latest record. July 22, 1904, three eggs (L. B. B.).

Spotted eggs have occasionally been taken by J. H. S., W. W. C., ${ }^{6}$ J. N. C., ${ }^{6}$ and W. R. Nichols.

(1) Merriam, Birds of Conn., p. 8.

2 Bull. Nuttall Ornith. Club, viii, 3, p. 179.

3 . and 0 ., xii, 9, p. 156 .

4 Auk, iii, 4, p. 487 .

SAuk, x, I, p. 89.

- Merriam, Birds of Conn., p. 6. 
A young albino without a single dark feather was taken in Trumbull, July Io, I889 (in Averill coll. of the Bpt. Sci. Soc.).

Hylocichla fuscescens fuscescens (Stephens). Wilson's Thrush. Veery.

A common summer resident of damp woodland throughout the state from May until July.

Earliest record. New Haven, May I, I896, April 30, I888 (L. B. W.), I906 (A. A. S.) ; Portland, April 27, I907.

Latest record. New Haven, Sept. 22, I903; Portland, Aug. 30, 1894 .

Nest. On the ground underneath a bush or among dead leaves in the woods, in a tussock of grass in a swamp, very rarely as much as a foot above the ground in a bush. Building, May I 5-30.

Eggs. 4-5; the last of May.

Nesting dates. Earliest record. May 20, 1900, three eggs (J. C. A. M.). Latest record. June I3, I905, Litchfield (E. S. W.).

Spotted eggs were found in Litchfield, May 30, 1903 (L. B. W. and E. S. W.).

Hylocichla fuscescens salicicola Ridgway. Willow Thrush.

A visitor from the West during migrations.

Connecticut records. May 5, I894, Woodbridge; Sept. 23, I895, New Haven; May 16, I900, May I4, I904, East Haven; each time an adult male taken by L. B. B.

Hylocichla aliciæ aliciæ (Baird). Gray-cheeked Thrush. A common spring and fall migrant in May and September.

Spring migration. Earliest record. New Haven, May 9, I900; Portland, May II, I893; Litchfield, May 7, I905 (E. S. W.). Latest record. New Haven, May 27, I896, May 29, 1907 (A. A. S.) ; Portland, May 27, I885; Seymour, May 29, I888 (Eames) ; Bridgeport, May 29, I889 (Eames).

Fall migration. Earliest record. New Haven, Sept. 5, 1906; Portland, Sept. I4, I895. Latest record. New Haven, Oct. II, 1906; Portland, Sept. 26, 1893; East Hartford, Oct. 5, 1887 (W. E. T.). 
Hylocichla aliciæ bicknelli Ridgway. Bicknell's Thrush.

A rather rare spring and fall migrant in May and late September; associating with the Gray-cheeked Thrush.

Spring migration. New Haven, May I5 (1907, I908)-May 22 (1902).

Fall migration. New Haven, Sept. I7 (I903)-Oct. 24 (1895). H. W. F.

Spring records. May 16, I900, May 22, I902, May 20, 1906, May 15, 1907, 1908, New Haven (L. B. B.).

Fall records. Sept. 23, I893, Stamford, male (Porter); Oct. 3, 1895, New Haven, male (A. H. V., in coll. of L. B. B.) ; Oct. 24, I895, New Haven, male (H. W. F.) ; Sept. I7, 30, Oct. 3, 1903, Sept. 21, 1904, Oct. I, I904, Sept 27, 1905, Oct. 9, I906, Oct. 5, I907, Oct. 9, I9I I, New Haven (L. B. B.) ; Oct. I I, I906, New Haven (E. S. W.) ; Oct. 3, 1908, Easton ( H. W. B.).

Hylocichla ustulata swainsoni (Tschudi). Olive-backed Thrush.

A tolerably common spring and fall migrant in May and September.

Spring migration. Earliest record. New Haven, May Io, I900, I904; Portland, May 7, I894. Latest record. New Haven, May 25, I908, May 29, I907 (A. A. S.) ; Portland, May 29, I893.

Fall migration. Earliest record. New Haven, Sept. 7, I903, Sept. 4, I874 (Hall) ;' Portland, Sept. 28, 1876. Latest record. New Haven, Oct. 4, I895, I90 I, Oct. I2, I887 (H. W. F.), Oct. I3 (Merriam) ; Portland, Oct. 5, I886; Litchfield, Oct. I9, I886 (L. B. W.) ; Guilford, Nov. Io, I906 (E. S. W.).

Hylocichla guttata pallasi (Cabanis). Hermit Thrush.

A common spring and fall migrant in April and October, breeding regularly in the northwestern part of the state, and wintering rarely along the coast.

Spring migration. Earliest record. New Haven, March I6, I907; Portland, April 6, I875, I888. Latest record. May I7, I907, May 18, I893 (A. H. V.) ; Portland, May 8, 1888.

Fall migration. Earliest record. New Haven, Sept. 29, 1883; Portland, Oct. 2, I893, I899. Latest record. New Haven, Dec. 
I, I883; Portland, Oct. 27, I884, I885; East Hartford, Nov. 8, 1890 (W. E. T.).

Winter records. Dec. I4, 22, I877, Portland (J. H. S.) ; March I, I878, New Haven (Hotchkiss) ; Jan. 6, I882, Guilford (L. B. B.) ; Jan., I883, Saybrook (J. N. C.) ; 1 Dec. 26, I892, New Haven (H. W. F.) ; Jan. 22, I896, East Haven (L. B. B.) ; Jan. 8, I90I, Portland (J. H. S.) ; Dec. I8, I903, Guilford (L. B. B.) ; Jan. I, I904, Bristol (Smith and Bruen) ; Jan. I9, I907, New Haven (A. A. S.) ; Feb. I3, I9I I, Portland (J. H. S.).

Summer records. June I9, I887, Hartford County, nest with three eggs found ("An Observer"); July 2, I89I, Litchfield, speckled young found, probably one of a brood raised near by (L. B. W.) ; June 20, 23, I893, two nests containing three eggs each taken at Norfolk (J. H. S.) ; June I8, 1904, Salisbury, several heard and one taken (J. H. S. and L. B. B.) ; May 27, I905, Litchfield, breeding female taken (E. S. W.) ; July, I906, Salisbury (H. K. J.) ; June 23, I907, Litchfield, male in song (E. S. W.).

Planesticus migratorius migratorius (Linnæus). Robin.

An abundant summer and an irregular winter resident; the majority arriving in March and leaving in October.

Earliest record. ${ }^{5}$ New Haven, March 7, I903, I9I0, March 3, I902 (A. A. S.) ; Portland, March 3, 1884.

Latest record. ${ }^{5}$ New Haven, Nov. 28, I900, I903; Portland, Nov. 27, I881.

Winter records. This species has been recorded in January, February, or December, in New Haven, I882, I883, I884, I885, I886, I896, I902, I903, 1904, I905 (L. B. B.) ; 1887 (L. B. W.); 1906 (E. S. W.) ; 1907, 1908, 1909, I910 (D. B. P.) ; in Portland, I863, I880, I882, I885, I886, I890, I891, I892, I893, І896, I897, I899, I900, I905, 1906, I907, I910 (J. H. S.). A few probably winter regularly each year.

Nest. In almost every possible situation; the fork of a limb of a tree, on a stump close to the ground, on a fallen limb, a pile

10 . and $O$., viii, 10, p. 80 .

2 Ölogist, viii, 4, p. 92.

'Auk, ix, 2, p. 202.

4 Auk, x, 4, p. $37 \mathrm{r}$.

- Migrants. 
of brush, a tree-box, on the porch of a house or the rafter of a barn, on a ledge of rocks, on a fence rail - most frequently in a tree. Height from ground, 3-60 feet; rarely, on the ground. Building, April 5 to May ro.

Eggs. 2-5, usually 3 or 4 ; early in May.

Nesting dates. Earliest record. April 21, I883, two eggs (L. B. B.). Latest record. August 3, r882, four young (L. B. B.).

Spotted eggs are occasionally found; e. g., I884, Guilford, set of four, profusely but faintly spotted with Mars brown (Wildman) ; 1885 , ibid., four more heavily marked (Wildman); May 28, 1897, Woodbridge, set of three (H. W. F.).

Runt eggs have been noted: June 3, r882, Guilford, two (L. B. B.) ; June Io, I894, Branford, one (L. B. B.).

Peculiar nests. May 12, I894, New Haven, nest made of thin strips of tissue paper, which depended from it in long streamers (A. H. V.) ; May 22, 1898, nest with four eggs on the ground on a railroad embankment. (J. C. A. M.) ; May 15, 1903, Trumbull, twin nest on girder in a barn, one containing four eggs of Robin, the other five deserted eggs of Phœbe (Beers); May 7, 1907, Portland, nest in old Flicker's hole (J. H. S.).

Partial albinos are quite common, having been noted a number of times in New Haven by L. B. B., and in Portland by J. H. S.

The Robin has been heard singing as late as Oct. 29 (I895) by L. B. B.

\section{Sialia sialis sialis (Linnæus). Bluebird.}

An abundant summer and common winter resident; migrants arriving early in March and leaving in October and November.

Earliest record. ${ }^{1}$ New Haven, March 6, I894, March 4, I90r, 1906 (A. A. S.) ; Portland, March 2, 1900.

Latest record. ${ }^{1}$ New Haven, Nov. 25, 1903, Nov. 26, 1906 (A. A. S.) ; Portland, Nov. 27, 1889.

Winter records. This species has been recorded in January, February, or December, in New Haven, I882, I883, 1884, I886, I888, I889, I896, I898, I900, I901, I902, 1903, I904 (L. B. B.) ; I887 (L. B. W.) ; 1906 (E. S. W.) ; 1907, I908, I909, I9ro (D. B. P.) ; in Portland, I86r, I87r, 1874, I877, 1878, I880, I881, 
I882, I883, 1884, 1886, 1890, 1891, 1893, 1895, 1896, 1898, I901, 1903, 1905, 1907, 1908, 1909, 1910, 191 I (J. H. S.).

Nest. In a box or natural hole in a tree, or in the deserted home of a woodpecker; usually in an orchard but occasionally in deep woods; $3 \frac{T}{2}$ to 20 feet from the ground.

Eggs. $3-7$, usually 4 or 5 ; the last of April.

Nesting dates. Earliest record. April 12, 1898, seven eggs (Hill). Latest record. July 8, 1882, three eggs (L. B. B.).

White eggs have several times been found; e.g., May 30 , 1876, Essex, four (H. W. F.) ; July 8, 1882, Guilford, three (L. B. B.) ; May 23, I892, Stamford (Rowell) ; April 28, 1898, Newtown, four (Canfield).

Although the Bluebird was almost exterminated in the winter of 1895 by the long continued cold weather in the South, and was consequently very rare that summer and in 1896 , yet it had regained its former abundance by 1898 .

This species while wintering has been found inside of a stack of hay, Feb. 22, I886 (L. B. B.), in an old Robin's nest, Feb. II, 1882 (L. B. B.), March 3I, 1906 (E. S. W. and L. B. B.), in a hollow post in mid-winter, about 1883 (Augur). It probably chooses such sheltered places in which to pass the nights.

This species has been heard singing as early as Feb. 28 (I883), and as late as Oct. 22 (1892), by L. B. B.

A male Bluebird of a brilliant cobalt-blue, like Florida specimens, was taken April I3, I90I, New Haven, by L. B. B. 



\section{APPENDICES TO PART I.}

\section{CATALOGUE OF INTRODUCED SPECIES AND DOUBTFUL SPECIES.}

Chenalopex ægyptiaca (Linnæus). Egyptian Goose.

Two were seen flying about the Connecticut river, at Portland, Oct. 20, I895, and one was shot. Both were undoubtedly escaped tame birds; but they must have come from a distance, as none, so far as is known, were ever kept within twenty miles of Portland.

Grus americana (Linnæus). Whooping Crane.

Grus mexicana (Müller). Sandhill Crane.

Though these species are reported by many of the earlier writers on Natural History as more or less common in the surrounding states, there seems to be no definite record of the capture of either in Connecticut. Undoubtedly both occurred when the country was discovered, but there is little probability that either has been taken within the last hundred years.

Erolia ferruginea (Brünnich). Curlew Sandpiper.

There are but two records of this species in this state, both appearing in Merriam:1 one shot near Saybrook "some time ago" (J. G. Ely, I877), and one killed Oct. 3, I859, East Hartford (reported by Dr. D. Crary of Hartford). Neither of these records can be considered absolutely trustworthy.

The record of Dr. Thompson, as reported by Merriam, was proven later by L. C. S. to be that of a Stilt Sandpiper.

Coturnix coturnix (Linnæus). European Quail. Migratory Quail.

Numbers of these birds were liberated in I878, at Lakeville, by the Salisbury Bird and Fish Protective Company. They nested 
that year and also in 1879 , but so far as we know none are now to be found.

Perdix perdix (Linnæus). Gray Partridge.

During 1908 and 1909 about 3,000 birds of this species were imported from Europe by our Game Commission and released in different parts of Connecticut, and a large number in 1910. ${ }^{1}$ As the majority brought to the United States came from Hungary, this bird has become commonly known as the Hungarian Partridge.

During I909 a number were reported to have mated and raised young, but the majority seem to have disappeared. However, it is yet too soon to pronounce on the success of this attempt at introducing a foreign game-bird into our state.

Tympanuchus cupido (Linnæus). Heath Hen.

Abundant in dry, bushy places in southern New England in the days of the first white settlers, this species had been exterminated in Connecticut before the time of Linsley, but was reported to be still found in "shrubby barrens in Westford, Connecticut," by Nuttall, ${ }^{2}$ who wrote some ten years earlier.

Phasianus colchicus (Linnæus). English Pheasant.

Phasianus torquatus Gmelin. Ring Pheasant.

Numbers of both these Pheasants were liberated by sportsmen at various places in Connecticut at different times between I 890 and I900; but none of them seems to have succeeded in becoming acclimated, and almost all have disappeared.

The only records are: June 2, I897, New Haven, one flushed (L. B. B.) ; Dec. 27, I90I, Gaylordsville, one female found, apparently killed by a hawk (E. H. A.) ; fall, I904, some reported seen in the Connecticut valley (according to J. E. Bassett).

Meleagris gallopavo silvestris (Viellot). Wild Turkey.

With a history somewhat similar to that of the Heath Hen, and probably originally much more common over most of Connecticut, the Wild Turkey disappeared about the same date.

Linsley states: "The last wild turkey that I have known in Connecticut, was taken by a relative of mine, about thirty years since, on Totoket Mountain, in Northford. It was overtaken in

: Oldys, Yearbook Dept. Agriculture for 1909, pp. 255-6.

2 Manual of the Ornithology of the United States and of Canada - the Land Birds, 1832 , p. 662 . 
a deep snow, and thereby outrun. It weighed, when dressed, twenty-one pounds." 1

Sturnus vulgaris Linnæus. Starling.

An increasingly common resident.

This species was introduced into New York City in I890, whence it has spread from Central Park through the neighboring country. It is constantly increasing in numbers, and is now firmly established through various parts of the state, especially along the coast.

Its spread may be shown by the following records of its first occurrence: June Io, I900, Norwalk (Ells), ${ }^{2}$ also winter, I900-I ; Aug. 25, Ig00, Stamford (Smith, reported by Hoyt) ; Dec. 3, I900, North Haven (L. B. B.) ; Jan., I90I, reported from Noroton, Stamford, and Norwalk; Oct., Igor, New Haven (A. A. S.) ; ${ }^{2}$ winter, I902-3, New Haven, five or six wintered; winter, I903-4, about forty wintered; fall, I906, flock of about 1500 seen (A. A. S. ) ; Jan., I904, Bridgeport (Eames) ; spring, I906, Wethersfield (Morgan) ;' March, I906, Danbury (J. C. A. M.) ; 1906, New London and Stonington (Buttrick); April, I907, Bethel (Judd) ;' June, I907, Middletown (Cady); I908, Portland (J. H. S.).

Since these records, they have increased very rapidly and are breeding in large numbers. Mrs. Bonner writes from Stamford : "They have appropriated not only all the holes in the old apple trees, including those stolen from the Bluebirds by the English Sparrows, but also the holes in all the big lawn trees, hitherto occupied by Flickers, etc." It is not yet numerous in the interior of the state.

Nest. In a hollow of some sort, or in a church steeple.

Eggs. 4-6; the last of April.

Nesting dates. Earliest record. May 5, 1904, six young (Perry); May 2, I9Io, three eggs (J. H. S.). Latest record. July II, 1904, two young (L. B. B.).

Carduelis carduelis (Linnæus). European Goldfinch.

G. E. Verrill of New Haven writes in the $A u k$, ix, 3, p. 30I : "On May 9, I892, I took a very full-plumaged male European 1843 .

${ }^{1}$ Catalogue of the Birds of Connecticut, Am. Jour. Sci. and Arts, xliv, 2, p. 264,

2 Bird-Lore, ix, 5, pp. 207-9.

3 Bird-Lore, ix, 4, p. 171 . 
Goldfinch in an orchard near here. The bird was in full song, and did not bear any evidence of having been in captivity, as it was not particularly tame; the plumage was perfect, even to the tips of the tail feathers, and the legs and feet were those of a wild bird. It seems to me probable that it was a straggler from some of the localities where they have been introduced and have become naturalized, as I have never seen any near here before."

This is the only published record of this species in this state.

This specimen is now in the Peabody Museum. It was probably a wanderer from a small colony in Central Park, New York City.

Passer domesticus (Linnæus). English Sparrow.

"Introduced into Boston by the city government in 1868 ", by 1877 the English Sparrow was " an abundant resident in all the larger and most of the smaller towns throughout the state (Connecticut). ${ }^{2}$

An abundant resident of the cities, villages, and farms, having driven Martins and Bluebirds and Eave Swallows from their nesting sites, as well as routing out other species by its warlike habits.

Nest. Breeds in any hole it can find, in martin-boxes, in holes in trees, or in buildings. Wanting these, it will occupy a Cliff Swallow's or Eave Swallow's nest, or build rough nests behind window blinds, in ivy on buildings, or in trees. Occasionally it adopts the habit of woodpeckers, chipping out a hole for itself in a tree after it has been started by a woodpecker (e. g., March 21, I910, L. B. B.).

Eggs. 4-6; early in April, and successively throughout the summer.

Nesting dates. Earliest record. March 28, I898, five eggs (J. C. A. M.). Latest record. July 6, I89I, five eggs (J. C. A. M.).

A set of five white eggs was taken, May 22, I889, New Haven, by C. F. Hedges, where another set had been found in the previous year. birds.

Partial albinos are quite common, especially among young

\footnotetext{
1 Baird, Brewer \& Ridgway, Birds of North America, i, p. 526.

2 Merriam, Birds of Connecticut, p. 40.
} 
Courting antics have been noticed as early (or late) as Dec. 24,1903 (L. B. B.).

New Haven, Dec. I0, I900, male with lower mandible gone and upper grown to a remarkable length, taken (A. H. V., in coll. of L. B. B.).

Guiraca cærulea cærulea (Linnæus). Blue Grosbeak.

Connecticut records: May 9, 1902, Bethel, male seen in an orchard (Hamlin) ; summer, I903, New Canaan, one seen (Mrs. Neidé, recorded by Hoyt).

Vermivora lawrencei (Herrick). Lawrence's Warbler.

Vermivora leucobronchialis (Brewster). Brewster's Warbler.

Although it seems now beyond question that the birds called by these names are not independent species, it has not yet been conclusively shown whether they are hybrids between Vermivora pinus and $V$. chrysoptera, or phases of plumage of these species. Brewster's Warbler completely intergrades with the Blue-winged, while males at least of Lawrence's show usually little variation in plumage. As a very large proportion of the specimens of these puzzling birds so far reported were taken in Connecticut, we have tried to give here a summary of these records with the addition of others. Brewster's Warbler is much the more common.

Vermivora lawrencei. Greenwich, July I2, I893, female taken, with young in first plumage, by C. G. Voorhees. ${ }^{1}$ Stamford, May I2, I886, male taken, May 23, I888, female taken, May 25, I888, male taken (W. H. H., last two in coll. of L. H. P.) ; May 25, I905, male taken (L. B. B.). Greenfield Hills, May 3I, I906, male seen (E. S. W.). Danbury, I900 (?), male taken (J. C. A. M.). Bridgeport, May 16, I889, male taken, spring of I89I, three seen, seven seen in one spring ${ }^{2}$ (E. H. E.). New Haven, May 2I, I888, female taken, May I3, I89I, male taken (H. W. F., these in coll. of W. Brewster); May I7, I892, male taken (H. W. F.) ; May 15, 1896, male taken, May 21, I902, female, intermediate with $V$. chrysoptera mated with a male $V$. pinus, taken (A. H. V., all in coll. of L. B. B.) ; May I3, 2I, I898, two males taken (A. H. V.) ; May 20, I896, male taken, 
May II, I900, male taken, intermediate with $V$. chrysoptera, May Io, 1904, male taken, May 31, 1905, male taken, May 24, I906, male taken, May 20, I909, male taken (these three within space of 300 yards), June 4, I909, male taken with mate female $V$. pinus, and four eggs and two Cowbird's eggs, May 21, I912, male taken (L. B. B.) ; May 29, I906, male seen (J. Dwight, Jr., and L. B. B.). Portland, May I4, I887, May I6, I894, May Io, I895, three males taken (S. R., all in coll. of J. H. S.).

Vèrmivora leucobronchialis. Wauregan (Plainfield), May 25, I875, male taken (C. M. Carpenter). ${ }^{1}$ Suffield, July 3, I875, male taken (E. I. Shores). ${ }^{2}$ Saybrook, May 30, I879, male taken, ${ }^{3}$ spring of 1880 , one seen, ${ }^{4}$ May I3, 1888 , one seen, May 8 , I889, one taken, ${ }^{5}$ frequently seen and taken and nest found (J. N. C.). Stamford, May 20, I893, male taken (L. H. P.). Bridgeport, June I4, I892, male seen mated with $V$. pinus, nest contained four eggs, two of which were Cowbird's (E. H. E.) ; fifteen males seen between Bridgeport and Seymour, spring of I889 (E. H. E.) ; Seymour, May 26, 29, male taken, June I, 4, Io, two, June I9, July 7, I888, seen (E. H. E.). ${ }^{7}$ Milford, June 2, I903, female taken with six eggs and one Cowbird's egg ( J. C. A. M., female in coll. of L. B. B.). Deep River, May 18, 1880, female taken. ${ }^{8}$ New Haven, May 19, 1885, male taken (H. W. F., in coll. of J. H. S.), May I5, I888, one seen, May I6, I892, male taken, May I7, I892, two males taken, May I2, 1893, male taken (H. W. F.) ; May, 1894, male taken (W. C. Morgan) ; May I4, I896, male taken, May 28, I898, female taken, mated with $V$. pinus, and five eggs, May 19, I902, male taken (A. H. V., all in coll. of L. B. B.) ; May (?), rgo5, male taken (E. S. W.) ; May 8-31, I893, I894, I896, I898, I900, I902, I904, I905, I906, and I9Io, nineteen males taken, one mated with $V$. pinus, July 4, 1893, female taken with two young, slightly paler yellow than $V$. pinus, May 24, I904, female taken, June 10, 1904, female

1 Bull. Nuttall Orn. Club, iii, 2, p. 99.

2 Bull. Nuttall Orn. Club, iii, 4, pp. 199-200.

8 Bull. Nuttall Orn. Club, iv, 3, p. 184.

4 Random Notes on Natural Hist., ii, 6, p. 43.

30 . and 0 ., xiv, $8, \mathrm{p} I \mathrm{I} 9$.

6 Auk, x, 1, pp. 89-90.

$7 A u k, v, 4$, pp. $427-428$.

8 Auk, i, 1, p. 91 . 
taken with four young dead in the nest, Sept. 12, 1907, young male taken, May 24, I9r2, female taken (L. B. B.). Portland, May 22, 1875, male taken (W. W. C.) , ${ }^{1}$ May 31, 1886, May 26 , I887, males taken, May Io, I888, male taken and another seen, June 10, I889, May 24, I89o, May 15, I891, males taken, June 13, I891, one seen, May I3, I7, 1892, two males taken, May 30, June 2-15, 1893, one seen, May Io, I2, I894, three males taken, May 25, 30, June II, 1894, four males seen, June 23, I894, female taken mated with $V$. chrysoptera, and four eggs, May I3, I895, male taken, May 23, 30, 1896, May I3, 15, I7, I899, May I4, I900, May 12, I901, seen, May 7, I902, male taken, May 30, 1903, May 18, 1907, seen, June 6, 1908, male taken (S. R. and J. H. S.); May 27, 1904, male taken (L. B. B.). Waterbury, May 9, 1909, one seen (N. B. Pillery). ${ }^{2}$

Dr. Eames has found this birel mated with $V$. pinus alone, and has found nests and watched the young develop into same plumages as the juvenal of $V$. pinus.

Turdus pilaris (Linnæus). Fieldfare.

Accidental.

The only Connecticut record is that of a specimen taken near Stamford in April, $1878,{ }^{3}$ by Schaler, who states that its actions were those of a wild bird. This specimen is now in the collection of Hoyt, and from the condition of its plumage and feet had certainly not been recently in captivity.

1 Bull. Nuttall Orn. Club, iv, 3, p. 184.

2 Bird-Lore, xii, 2, pp. 78-9.

3 . and $O$., xiv, 3, p. 44. (The date here is incorrect.) 


\section{STATISTICAL SUMMARY.}

Gavia immer ${ }^{1}$

Anas rubripes

Marila marila ${ }^{1}$

Marila affinis ${ }^{1}$

Harelda hyemalis ${ }^{x}$

Charitonetta albeola ${ }^{1}$

Oidemia deglandi ${ }^{1}$

Oidemia perspicillata ${ }^{x}$

Botaurus lentiginosus ${ }^{2}$

Rallus crepitans crepitans ${ }^{2}$

Philohela minor ${ }^{2}$

Gallinago delicata ${ }^{3}$

Oxyechus vociferus ${ }^{3}$

Colinus virginianus virginianus

Bonasa umbellus umbellus

Bonasa umbellus togata

Zenaidura macroura carolinensis ${ }^{2}$

Circus hudsonius

Accipiter velox

Accipiter cooperi

Astur atricapillus atricapillus ${ }^{1}$

Buteo borealis borealis

Buteo lineatus lineatus

Haliæetus leucocephalus leucocephalus

Falco peregrinus anatum ${ }^{8}$

Falco sparverius sparverius

Aluco pratincola ${ }^{3}$

Asio wilsonianus

Asio flammeus ${ }^{3}$

Strix varia varia

Cryptoglaux acadica acadica ${ }^{1}$

Otus asio asio

Bubo virginianus virginianus

Ceryle alcyon ${ }^{2}$

Dryobates villosus villosus

Dryobates pubescens medianus

Sphyrapicus varius varius ${ }^{3}$

Phlootomus pileatus abieticola

Melanerpes erythrocephalus ${ }^{2}$

1 Rare or accidental in summer.

2 Rare or accidental in winter.
RESIDENTS.

Colaptes auratus luteus ${ }^{2}$

Sayornis phœbe ${ }^{2}$

Otocoris alpestris praticola

Cyanocitta cristata cristata

Corvus brachyrhynchos

brachyrhynchos

Corvus ossifragus ${ }^{2}$

Molothrus ater ater ${ }^{2}$

Agelaius phœniceus phœniceus ${ }^{2}$

Sturnella magna magna

Quiscalus quiscula æneus ${ }^{3}$

Carpodacus purpureus purpureus ${ }^{2}$

Astragalinus tristis tristis

Poœcetes gramineus gramineus ${ }^{2}$

Passerculus sandwichensis savanna ${ }^{2}$

Passerherbulus caudacutus ${ }^{2}$

Passerherbulus maritimus maritimus $^{2}$

Zonotrichia albicollis ${ }^{3}$

Spizella pusilla pusilla ${ }^{2}$

Junco hyemalis hyemalis ${ }^{1}$

Melospiza melodia melodia

Melospiza georgiana ${ }^{2}$

Pipilo erythrophthalmus erythrophthalmus ${ }^{2}$

Iridoprocne bicolor ${ }^{2}$

Bombycilla cedrorum

Lanius ludovicianus migrans ${ }^{1}$

Dumetella carolinensis ${ }^{2}$

Toxostoma rufum ${ }^{2}$

Thryothorus ludovicianus

ludovicianus

Nannus hiemalis hiemalis ${ }^{3}$

Telmatodytes palustris palustris ${ }^{2}$

Sitta carolinensis carolinensis

Sitta canadensis ${ }^{1}$

Penthestes atricapillus atricapillus

Hylocichla guttata pallasi ${ }^{8}$

Planesticus migratorius migratorius

Sialia sialis sialis

${ }^{3}$ Rare or accidental both in summer andin winter. 
Phasianus colchicus Phasianus torquatus

Perdix perdix
Sturnus vulgaris

Passer domesticus

\section{SUMMER RESIDENTS. ${ }^{1}$}

Podilymbus podiceps

Sterna hirundo

Sterna dougalli

Aix sponsa

Ixobrychus exilis

Ardea herodias herodias

Butorides virescens virescens

Nycticorax nycticorax nævius

Rallus elegans

Rallus virginianus

Porzana carolina

Creciscus jamaicensis

Bartramia longicauda

Actitis macularia

Ectopistes migratorius ${ }^{2}$

Buteo platypterus

Pandion haliaëtus carolinensis

Coccyzus americanus americanus

Coccyzus erythrophthalmus

Antrostomus vociferus vociferus

Chordeiles virginianus virginianus

Chætura pelagica

Archilochus colubris

Tyrannus tyrannus

Myiarchus crinitus

Nuttallornis borealis

Myiochanes virens

Empidonax virescens

Empidonax trailli alnorum

Empidonax minimus

Dolichonyx oryzivorus

Icterus spurius

Icterus galbula

Quiscalus quiscula quiscula

Ammodramus savannarum australis

Passerherbulus henslowi henslowi
Spizella passerina passerina

Zamelodia ludoviciana

Passerina cyanea

Spiza americana ${ }^{2}$

Piranga erythromelas

Progne subis subis

Petrochelidon lunifrons lunifrons

Hirundo erythrogastra

Riparia riparia

Stelgidopteryx serripennis

Vireosylva olivacea

Vireosylva gilva gilva

Lanivireo flavifrons

Lanivireo solitarius solitarius

Vireo griseus griseus

Mniotilta varia

Helmitheros vermivorus

Vermivora pinus

Vermivora chrysoptera

Vermivora rubricapilla rubricapilla

Compsothlypis americana usneæ

Dendroica æstiva æstiva

Dendroica cærulescens cærulescens

Dendroica magnolia

Dendroica pensylvanica

Dendroica fusca

Dendroica virens

Dendroica vigorsi

Dendroica discolor

Seiurus aurocapillus

Seiurus motacilla

Oporornis formosus

Geothlypis trichas trichas

Icteria virens virens

Wilsonia citrina

Wilsonia canadensis

Setophaga ruticilla

${ }^{1}$ Besides those included in list of residents.

${ }^{2}$ Extinct in Connecticut. 
Mimus polyglottos polyglottos

Troglodytes aëdon aëdon

Cistothorus stellaris
Hylocichla mustelina

Hylocichla fuscescens fuscescers

\section{WINTER RESIDENTS. ${ }^{1}$}

Colymbus holbœlli

Colymbus auritus

Gavia stellata

Larus marinus

Larus argentatus

Mergus americanus

Mergus serrator

Anas platyrhynchos

Mareca americana

Nettion carolinense

Marila americana

Clangula clangula americana

Branta canadensis canadensis

Branta bernicla glaucogastra

Arquatella maritima maritima

Totanus melanoleucus

Archibuteo lagopus sancti-johannis

Haliæetus leucocephalus alascanus

Falco columbarius columbarius
Nyctea nyctea

Otocoris alpestris alpestris

Otocoris alpestris hoyti

Pinicola enucleator leucura

Loxia curvirostra minor

Loxia leucoptera

Acanthis linaria linaria

Spinus pinus

Plectrophenax nivalis nivalis

Calcarius lapponicus lapponicus

Passerculus princeps

Spizella monticola monticola

Passerella iliaca iliaca

Lanius borealis

Dendroica coronata

Dendroica palmarum hypochrysea

Anthus rubescens

Certhia familiaris americana

Regulus satrapa satrapa

\section{PERIODICAL VISITORS. ${ }^{2}$}

Podilymbus podiceps

Larus delawarensis

Larus philadelphia

Phalacrocorax carbo

Phalacrocorax auritus auritus

Lophodytes cucullatus

Anas platyrhynchos

Anas rubripes

Mareca americana

Nettion carolinense

Querquedula discors

Dafila acuta

Aix sponsa

Marila americana

Marila marila
Marila affinis

Oidemia americana

Oidemia deglandi

Oidemia perspicillata

Erismatura jamaicensis

Branta canadensis canadensis

Branta bernicla glaucogastra

Botaurus lentiginosus

Ixobrychus exilis

Ardea herodias herodias

Rallus virginianus

Porzana carolina

Coturnicops noveboracensis

Gallinula galeata

Fulica americana

${ }^{1}$ Besides those included in list of residents.

2 Species occurring chiefly in the spring or fall migration. A number of the names in this list are included also in the previous lists. 
Philohela minor

Gallinago delicata

Macrorhamphus griseus griseus

Arquatella maritima maritima

Pisobia maculata

Pisobia fuscicollis

Pisobia minutilla

Pelidna alpina sakhalina

Ereunetes pusillus

Calidris leucophæa

Totanus melanoleucus

Totanus flavipes

Helodromas solitarius solitarius

Bartramia longicauda

Numenius hudsonicus

Squatarola squatarola

Charadrius dominicus dominicus

Oxyechus vociferus

Egialitis semipalmata

Egialitis meloda

Arenaria interpres morinella

Ectopistes migratorius ${ }^{1}$

Circus hudsonius

Accipiter velox

Accipiter cooperi

Buteo borealis borealis

Buteo platypterus

Haliæetus leucocephalus

leucocephalus

Falco peregrinus anatum

Falco columbarius columbarius

Falco sparverius sparverius

Pandion haliaëtus carolinensis

Asio flammeus

Sphyrapicus varius varius

Melanerpes erythrocephalus

Colaptes auratus luteus

Chordeiles virginianus virginianus

Nuttallornis borealis

Empidonax flaviventris

Empidonax trailli alnorum

Euphagus carolinus"

Quiscalus quiscula æneus

Carpodacus purpureus purpureus

Spinus pinus

Plectrophenax nivalis nivalis
Calcarius lapponicus lapponicus

Passerculus princeps

Passerculus sandwichensis savanna

Passerherbulus nelsoni nelsoni

Passerherbulus nelsoni subvirgatus

Zonotrichia leucophrys leucophrys

Zonotrichia albicollis

Junco hyemalis hyemalis

Melospiza lincolni lincolni

Melospiza georgiana

Passerella iliaca iliaca

Petrochelidon lunifrons lunifrons

Iridoprocne bicolor

Riparia riparia

Lanius ludovicianus migrans

Vireosylva philadelphica

Lanivireo solitarius solitarius

Mniotilta varia

Vermivora rubricapilla rubricapilla

Vermivora celata celata

Vermivora peregrina

Compsothlypis americana usneæ

Dendroica tigrina

Dendroica cærulescens cærulescens

Dendroica coronata

Dendroica magnolia

Dendroica castanea

Dendroica striata

Dendroica fusca

Dendroica virens

Dendroica vigorsi

Dendroica palmarum palmarum

Dendroica palmarum hypochrysea

Seiurus noveboracensis noveboracensis

Seiurus noveboracensis notabilis

Oporornis agilis

Oporornis philadelphia

Wilsonia pusilla pusilla

Wilsonia canadensis

Anthus rubescens

Nannus hiemalis hiemalis

Certhia familiaris americana

Sitta canadensis

Regulus satrapa satrapa

1 Probably extinct. 
Regulus calendula calendula Hylocichla aliciæe aliciæ Hylocichla aliciæ bicknelli
Hylocichla ustulata swainsoni Hylocichla guttata pallasi

\section{ACCIDENTAL VISITORS.}

Cepphus grylle

Uria lomvia lomvia

Alca torda

Alle alle

Stercorarius parasiticus

Stercorarius longicaudus

Rissa tridactyla tridactyla

Larus leucopterus

Larus kumlieni

Larus atricilla

Sterna paradisæa

Sterna antillarum

Sterna fuscata

Hydrochelidon nigra surinamensis

Rynchops nigra

Fulmarus glacialis glacialis

Puffinus gravis

Oceanodroma leucorhoa

Oceanites oceanicus

Sula leucogastra

Sula bassana

Pelecanus occidentalis

Fregata aquila

Chaulelasmus streperus

Spatula clypeata

Marila valisineria

Marila collaris

Clangula islandica

Histrionicus histrionicus

Camptorhynchus labradorius ${ }^{1}$

Somateria dresseri

Somateria spectabilis

Chen hyperboreus nivalis

Branta canadensis hutchinsi

Olor columbianus

Guara alba

Plegadis autumnalis

Herodias egretta

Egretta candidissima candidissima Florida cærulea
Crex crex

Ionornis martinicus

Phalaropus fulicarius

Lobipes lobatus

Steganopus tricolor

Recurvirostra americana

Macrorhamphus griseus scolopaceus

Micropalama himantopus

Tringa canutus

Pisobia bairdi

Ereunetes mauri

Limosa fedoa

Limosa hæmastica

Catoptrophorus semipalmatus semipalmatus

Catoptrophorus semipalmatus inornatus

Tryngites subruficollis

Numenius americanus

Numenius borealis ${ }^{2}$

Ochthodromus wilsonius

Hæmatopus palliatus

Cathartes aura septentrionalis

Catharista urubu

Elanoides forficatus

Aquila chrysaëtos

Falco rusticolus obsoletus

Scotiaptex nebulosa nebulosa

Cryptoglaux funerea richardsoni

Surnia ulula caparoch

Picoides arcticus

Centurus carolinus

Antrostomus carolinensis

Muscivora forficata

Corvus corax principalis

Xanthocephalus xanthocephalus

Agelaius phœrliceus fortis

Hesperiphona vespertina

vespertina

Acanthis hornemanni exilipes 
Acanthis linaria rostrata

Cardinalis cardinalis cardinalis

Piranga ludoviciana

Piranga rubra rubra

Bombycilla garrula

Protonotaria citrea
Dendroica cerulea

Mimus polyglottos polyglottos

Bxolophus bicolor

Penthestes hudsonicus hudsonicus

Polioptila cærulea cærulea

Hylocichla fuscescens salicicola

\section{RECAPITULATION}

Residents, 80

Summer Residents, $\quad 78$

Winter Residents,

38

Transient Visitors, $\quad$ I24

Accidental Visitors, $\quad 89$

Total,

$334^{1}$

Including 5 introduced species. In this total each name is counted only once. 


\section{LIST OF OBSERVERS REFERRED TO BY INITIALS OR BY SURNAMES.}

\begin{tabular}{|c|c|c|}
\hline Initials & Name & Location \\
\hline C. K. A. & C. K. Averill & Bridgeport \\
\hline C. K. A., Jr. & C. K. Averill & Bridgeport \\
\hline E. H. A. & E. H. Austin & Stratford and Gaylordsville \\
\hline H. W. B. & H. W. Beers & Bridgeport \\
\hline L. B. B. & Dr. L. B. Bishop & New Haven \\
\hline J. N. C. & *J. N. Clark & Saybrook \\
\hline W. I. C. & W. I. Comstock & Norwalk \\
\hline W. W. C. & *W. W. Coe & Portland \\
\hline E. H. E. & Dr. E. H. Eames & Bridgeport and Seymour \\
\hline H. W. F. & H. W. Flint & Deep River and New Haven \\
\hline A. J. G. & A. J. Granniss & East Haven \\
\hline H. T. G. & H. T. Gates & Hartford \\
\hline A. W. H. & A. W. Honeywill, Jr. & New Haven \\
\hline C. C. $\mathrm{H}$. & C. C. Hanmer & East Hartford \\
\hline C. G. H. & C. G. Hart & East Berlin \\
\hline C. R. H. & C. R. Hooker & New Haven \\
\hline G. L. H. & G. L. Hamlin & Bridgeport \\
\hline J. H. H. & J. H. Hill & New London \\
\hline P. B. H. & P. B. Haines & New Haven \\
\hline S. T. H. & *S. T. Holbrook & Norwich \\
\hline W. H. H. & W. H. Hoyt & Stamford \\
\hline H. K. J. & Rev. H. K. Job & Kent and New Haven \\
\hline C. E. L. & *C. E. Lincoln & Gildersleeve \\
\hline J. C. A. M. & J. C. A. Meeker & Bridgeport and Danbury \\
\hline C. H. N. & *C. H. Neff & Portland \\
\hline C. H. P. & C. H. Pangburn & New Haven \\
\hline D. B. P. & D. B. Pangburn & New Haven \\
\hline L. H. P. & L. H. Porter & Stamford \\
\hline C. L. R. & C. L. Rawson & Norwich \\
\hline S. R. & S. Robinson & Portland \\
\hline A. A. S. & A. A. Saunders & New Haven \\
\hline J. H. S. & J. H. Sage & Portland \\
\hline L. C. S. & Dr. L. C. Sanford & New Haven \\
\hline C. C. T. & Prof. C. C. Trowbridge & New Haven \\
\hline W. E. T. & W. E. Treat & East Hartford \\
\hline A. E. V. & Prof. A. E. Verrill & New Haven \\
\hline A. H. V. & A. H. Verrill & New Haven \\
\hline
\end{tabular}


Initials

G. E. V.

C. W. W.

E. S. W.

J. M. W.

L. B. W.

W. W.

Surname

Adam

Andrews

Augur

Austin

Averill

Ayres

Bailey

Baldwin

Barratt

Beers

Bernard

Blackwood

Bliss

Brewster

Brockway

Brooks

Bruen

Buck

Buttrick

Cady

Camp

Canfield

Carpenter

Case

Case

Clark

Crary

Dayan

Dickerman

Dunbar

Dutcher

Eames

Flint

Folsom

Gabriel

Gath

Goff
Name

G. E. Verrill

C. W. Webb

*E. S. Woodruff

C. L. Rawson

(Jennie May Whipple)

L. B. Woodruff

Dr. W. Wood

\section{Name}

Sarah W. Adam

A. R. Andrews

C. R. Augur

E. H. Austin

C. K. Averill, Jr.

*Dr. W. O. Ayres

A. S. Bailey

A. H. Baldwin

*Dr. J. Barratt

H. W. Beers

G. H. Bernard

W. Blackwood

W. P. Bliss

W. Brewster

A. W. Brockway

*Capt. O. N. Brooks

F. Bruen

H. R. Buck

P. L. Buttrick

Prof. W. G. Cady

R. D. Camp

*J. H. Canfield

C. M. Carpenter

C. M. Case

*G. R. Case

*J. N. Clark

*Dr. D. Crary

*A. J. Dayan

G. Dickerman

W. L. Dunbar

J. S. Dutcher

Dr. E. H. Eames

H. W. Flint

*E. A. Folsom

G. H. Gabriel

J. Gath

J. L. Goff
Location

New Haven

New Haven

New Haven and Litchfield

Norwich

New Haven and Litchfield

East Windsor Hill

Location

Canaan

New Haven

Woodbridge

Stratford and Gaylordsville

Bridgeport

East Hartford

Cobalt

New Haven

Middletown

Bridgeport

New Haven

New Haven

Middletown

Cambridge, Mass.

Hadlyme

Guilford

Bristol

Wethersfield

New Haven

Middletown

New Haven and Stamford

Bridgeport

Wauregan

Hartford

Norwich

Saybrook

Hartford

New Haven

Danbury

Bridgeport

Watertown

Bridgeport and Seymour

Deep River and New Haven

New Haven

Hartford

Torrington

Portland 


\begin{tabular}{|c|c|c|c|}
\hline Surname & & Name & Location \\
\hline Goodrich & & C. W. Goodrich & New Haven \\
\hline Gould & & *F. H. R. Gould & Portland \\
\hline Grinnell & & Dr. G. B. Grinnell & New Haven and Milford \\
\hline Hall & $\because$ & *Dr. F. W. Hall & New Haven \\
\hline Hamlin & & G. H. Hamlin & Bridgeport \\
\hline Hanson & & W. Hanson & Torrington \\
\hline Hedges & & C. F. Hedges & New Haven \\
\hline Herman & & O. Herman & New Haven \\
\hline Hill & & J. H. Hill & New London \\
\hline Holt & & J. Holt & Lyme \\
\hline Hooker & & C. R. Hooker & New Haven \\
\hline Hotchkiss & & *Dr. W. H. Hotchkiss & New Haven \\
\hline Howes & & P. G. Howes & Stamford \\
\hline Hoyt & & W. H. Hoyt & Stamford \\
\hline Humphrey & & ${ }^{*}$ H. C. Humphrey & Hartford \\
\hline Hurlbut & & H. M. Hurlbut & Portland \\
\hline Hurlbut & & *Seymour Hurlbut & Portland \\
\hline Hutchins & & J. Hutchins & Litchfield \\
\hline Job & & Rev. H. K. Job & Kent and New Haven \\
\hline Judd & & Rev. H. C. Judd & Bethel \\
\hline Judd & & R. S. Judd & Bethel \\
\hline Kedzie & & A. S. Kedzie & New Haven \\
\hline King & & L. E. King & Middletown \\
\hline Lester & & M. Lester & Suffield \\
\hline Linsley & & ${ }^{*}$ Rev. J. H. Linsley & Stratford \\
\hline Locke & & J. Locke & New Haven \\
\hline Lucas & & *W. H. Lucas & Bridgeport \\
\hline Ludington & & F. J. Ludington & North Haven \\
\hline Ludington & & H. Ludington & North Haven \\
\hline McCook & & P. J. McCook & Niantic \\
\hline Merriam & & Dr. C. H. Merriam & New Haven \\
\hline Miles & & W. A. Miles & Twin Lakes \\
\hline Minor & & W. T. Minor & New Haven \\
\hline Mitchell & & E. Mitchell & New Haven \\
\hline Morgan & & W. C. Morgan & New Haven \\
\hline Moses & & *S. G. Moses & Hartford \\
\hline Nichols & & *W. R. Nichols & Branford \\
\hline Norton & & R. Norton & Guilford \\
\hline Osborne & & A. D. Osborne, 3d. & New Haven \\
\hline Osborne & & T. B. Osborne & New Haven \\
\hline Pangburn & & C. H. Pangburn & New Haven \\
\hline Pangburn & & D. B. Pangburn & New Haven \\
\hline Parkinson & & Dr. G. H. Parkinson & Middletown \\
\hline Parsons & & *L. J. Parsons & New Haven \\
\hline Pease & & C. H. Pease & Canaan \\
\hline Perry & & Dr. E. Perry, Jr. & Bridgeport \\
\hline
\end{tabular}




\begin{tabular}{|c|c|c|}
\hline Surname & Name & Location \\
\hline Porter & L. H. Porter & Stamford \\
\hline Powers & A. G. Powers & Hartford \\
\hline Prior & C. E. Prior & Jewett City \\
\hline Rawson & C. L. Rawson & Norwich \\
\hline Reynolds & Prof. H. M. Reynolds & New Haven \\
\hline Robbins & W. A. Robbins & New Haven \\
\hline Robertson & J. B. Robertson & New Haven \\
\hline Rowell & Dr. C. Rowell & Stamford \\
\hline St. John & Prof. E. P. St. John & Hartford \\
\hline Sanford & H. Sanford & Litchfield \\
\hline Schaler & J. Schaler & Stamford \\
\hline Searles & E. Searles & New Haven \\
\hline Sherman & F. Sherman & New Haven \\
\hline Shores & Dr. E. I. Shores & Suffield \\
\hline Smith & E. Smith & Bristol \\
\hline Smith & G. V. Smith & New Haven \\
\hline Smith & M. T. Smith & Hartford \\
\hline Smith & Prof. S. I. Smith & New Haven \\
\hline Smith & W. F. Smith & South Norwalk \\
\hline Silliman & *Prof. B. Silliman & New Haven \\
\hline Sperry & *K. Sperry & New Haven \\
\hline Stetson & J. Y. Stetson & New Haven \\
\hline Stetson & Dr. P. R. Stetson & New Haven \\
\hline Strong & N. B. Strong & Portland \\
\hline Sweetland & A. R. Sweetland & \\
\hline Taylor & H. H. Taylor & Bridgeport \\
\hline Thompson & Dr. E. L. R. Thompson & New Haven \\
\hline Townsend & H. H. Townsend & New; Haven \\
\hline Trowbridge & Prof. C. C. Trowbridge & New Haven \\
\hline Tryon & *E. S. Tryon & Portland \\
\hline Uhl & J. Uhl & Montowese \\
\hline Verrill & Prof. A. E. Verrill & New Haven \\
\hline Voorhees & C. G. Voorhees & Greenwich \\
\hline Watrous & C. H. Watrous & Chester \\
\hline Webb & C. W. Webb & New Haven \\
\hline Welch & L. S. Welch & Hartford \\
\hline Werking & F. J. Werking & Taftsville \\
\hline Whitney & H. Whitney & New Haven \\
\hline Wildman & F. J. Wildman & Guilford \\
\hline Williams & C. H. Williams & Winchester \\
\hline Woolsey & Dr. G. Woolsey & New Haven \\
\hline
\end{tabular}




\section{BIBLIOGRAPHY.}

This list is far from complete, but it is believed to contain most of the important books and articles treating on Connecticut birds. The names of authors are arranged alphabetically, and the titles cited under the name of each author are arranged chronologically. The works on economic ornithology, quoted in the chapter on that subject, have, as a rule, been omitted here. Abbott, S. L.

1842. Remarks on Exhibition of some Birds from Connecticut.-Proc. Bost. Soc. Nat. Hist., i, p. 56.

\section{Adam, Sarah W.}

19I I. Evening Grosbeaks at Canaan.-Bird-Lore, xiii, 2, p. 94 .

Adams, Prof. Charles C.

1902. Postglacial Origin and Migration of the Life of the Northeastern United States.-Journ. of Geog., i, 7, pp. 303-310.

Alcott, William P.

I87o. Albino Snow Bird.-Am. Nat., iv, 6, p. 376.

Allen, Glover M., Ph.D.

1909. Fauna of New England. II. List of the Aves.Bost. Soc. Nat. Hist., Occasional Papers, vii.

Allen, Joel Asaph, Ph.D.

1860-3. Birds of New England.-Nerw England Farmer, 25 articles.

1864. Catalogue of the Birds found at Springfield, Mass.

- Proc. Essex Inst., iv, 2, pp. 48-49.

1865. Notes on the Habits and Distribution of the Duck Hawk, or American Peregrine Falcon, in the Breeding Season, and Description of the Eggs. -Proc. Essex Inst., iv, pp. I53-16r.

1868. Notes on the Red and Mottled Owls.-Am. Nat., ii, 6, pp. 327-329. 
I869-70. Notes on some of the Rarer Birds of Massachusetts.-Am. Nat., iii, Io, pp. 505-5I9; II, pp. $568-585 ; 12$, pp. $631-648$.

I871. On the Mammals and Winter Birds of East Florida, with an examination of certain assumed Specific Characters in Birds, and a Sketch of the Bird-Fauna of Eastern North America.Bull. Mus. Comp. Zool., ii, 3, pp. 161-450; pls. iv-viii.

1878. A List of the Birds of Massachusetts with annotations.-Bull. Essex Inst., x, pp. 3-37.

1880. Notice of Connecticut Records in Familiar Sci. and Fanciers' Journ., vols. $\mathrm{v}$ and vi.-Bull. Nutt. Orn. Club, v. 2, pp. II3-II4.

I88I. The Connecticut Warbler - a Correction.-Bull. Nutt. Orn. Club, vi, 2, p. II 4 .

1881. A Second Massachusetts Specimen of the Redbellied Woodpecker.-Bull. Nutt. Orn. Club, vi, 3 , p. 183 .

I883. Notices of Connecticut Records in the Ornithologist and Oölogist, Vol. vi, by J. H. Sage, J. N. Clark, Miss Wood, C. L. Rawson, C. M. Jones, S. T. Holbrook, and J. M. Wade.-Bull. Nutt. Orn. Club, viii, 3, pp. I73-I77.

1883. Notices of Connecticut Records in the Ornithologist and Oölogist, Vol. vii.-Bull Nutt. Orn. Club, viii, 4, pp. 234-237.

1885. Notices of Connecticut Records in the Ornithologist and Oölogist, Vol. viii.-Auk, ii, I, pp. 96-гог. 1886. Notices of Connecticut Records in Random Notes on Natural History, Vols. i, ii.-Auk, iii, 2, pp. 271-272.

1886. A Revised List of the Birds of Massachusetts.Bull. Am. Mus. Nat. Hist., i, 7, pp. 22I-27I.

1887. Platt on the Birds of Meriden, Conn.-Auk, iv, 2, p. I54.

1905. The Loggerhead Shrike in Connecticut in Winter. - Auk, xxii, 2, p. 2 II. 
Allis, Alice L.

I9I I. Evening Grosbeaks at Norwichtown.-Bird-Lore, xiii, 4, p. 209.

American Ornithologists' Union.

1886. The Code of Nomenclature and Check-List of North American Birds, adopted by the American Ornithologists' Union.

1895. Check-List of North American Birds, prepared by a Committee of the American Ornithologists' Union. Second and Revised Edition.

I910. Check-List of North American Birds, prepared by a Committee of the American Ornithologists' Union. Third Edition, revised.

Arnold, Mary Hazen.

1901. One Summer with a Fairy Housekeeper.- Am. Ornith., i, 10, pp. I95-197.

Audubon, J. J.

1840-44. The Birds of America, from Drawings made in the United States and their Territories.

Austin, E. H.

1888. An Early Yellow Rail - March 24.-Forest and Stream, xxx, II, p. 205.

Averill, C. K., Jr.

I884. Fox Sparrow in Winter.-O. and O., ix, 2, p. 22. I884. Two Connecticut Rarities.-O. and O., ix, 9, pp. I I I-I I2.

I885. The Northern Shrike as a Singer.-O. and O., $\mathrm{x}, 4, \mathrm{p} .53$.

1888. The Yellow Rail in Connecticut.-Auk, v, 3, p. 3 I9.

1889. The Loggerhead Shrike at Bridgeport, Conn.$A u k$, vi, I, p. 74.

1889. Tringa bairdii on Long Island Sound.-Auk, vi, 2, p. 189.

I889. Correction of Vol. vi, p. 74.-Auk, vi, 2, p. I92. 1890. The Evening Grosbeak in Connecticut.-Auk, vii, 2, p. 2 II. 
1891. Brünnich's Murre in Connecticut.-Auk, viii, 3, p. 307.

1892. List of Birds found in the vicinity of Bridgeport, Conn.-Bridgeport Scientific Society.

Ayres, Dr. W. O.

1854. Hirundo lunifrons at Hartford in 1833.-Proc. Boston Soc. Nat. Hist., iv, p. 270.

B., H. W. - See Beers, Henry W.

B., W. H.

I884. Red-winged Blackbird Nesting in Bushes.-Young Oölogist, i, I I, pp. I49-I 50.

Baird, Spencer F., Brewer, T. M., and Ridgway, Robert.

1874. A History of North American Birds - Land Birds. 1884. A History of North American Birds - Water Birds.

Baird, Spencer F., Cassin, John, and Lawrence, George N. 1858. Report on Explorations and Surveys for a Railroad from the Mississippi River to the Pacific Ocean. Vol. ix, Pt. ii, Birds.

Baird, Spencer F., Cassin, John, and Lawrence, George N. 1870. The Birds of North America. Vol. i, text; Vol. ii, plates.

Ball, Jennie C.

I905. How the Birds Come.-Bird-Lore, vii, 6, p. 280. Barratt, Dr. J.

1850. Black Egyptian Ibis (a Rare Bird), called also Glossy Ibis, Ibis falcinella.-Sentinel and Witness (Middletown), xxviii, 1430.

Barrows, Prof. Walter B.

1884. Abnormal Coloration in a Caged Robin.-Auk, i, r, p. 90.

1885. Abnormal Coloration in a Caged Robin.- Auk, ii, 3, p. 303 .

1885. Another Black Robin.- Auk, ii, 3, p. 303.

1889. The English Sparrow in North America.-U. S. Dept. Agriculture, Division of Economic Ornith. and Mamm., Bull. I. 
1889. The Food of Crows.-Ann. Report Dept. Agriculture for I888, pp. 498-535.

Barrows, Walter B., and Schwarz, E. A.

I895. The Common Crow of the United States - U. S. Dept. Agriculture, Division of Economic Ornith. and Mamm., Bull. 6 .

Batchelder, Charles F.

I890. An Early Yellow Rail.-Auk, vii, 4, p. 389.

Beers, Henry W.

I89I. Hawks' Nests.-O. and O., xvi, 2, p. 26.

I892. Nesting of the Great Horned Owl--O. and O., xvii, 4, p. 57 .

I892. A Day in the Woods.- 0 . and O., xvii, 5, pp. 68-69.

I9II. Set of Three Eggs of the Great Horned Owl.Oölogist, xxviii, 4, p. 79.

Bendire, Major Charles.

1892. Life Histories of North American Birds, with special reference to their Breeding Habits and Eggs. Part I. Gallinaceous Birds, Pigeons or Doves, Birds of Prey.-U. S. Nat. Mus. Special Bull. No. I.

I895. Same. Part II. Psittaceous Birds, Picarian Birds, Picine Birds, Macrochirine Birds, Passerine Birds.-U. S. Nat. Mus. Special Bull. No. 3 .

Betts, A. E.

1892. Late Nesting of Barn Swallows, Sept. 3d.-O. and O., xvii, II, p. I72.

Betts, Norman de W.

I9I0. Pied-Billed Grebe Nesting in Connecticut.-BirdLore, xii, 5, p. 199.

Bishop, Louis B., M. D.

1885. Ipswich Sparrow in Connecticut-O and O., $\mathrm{x}$, 2, p. 30.

1889. Helminthophila pinus, $H$. chrysoptera, $H$. leucobronchialis, and $H$. lazurence i in Connecticut in the Spring of I888.-Auk, vi, 2, p. I92. 
1893. The Breeding of Brewster's Warbler.-Abst. Linn. Soc., N. Y., vi. p. 10.

1894. Olor columbianus in Connecticut.-Auk, xi, I, p. 74.

1894. Hydrochelidon nigra surinamensis in Connecticut. - Auk, xi, I, p. 74.

1894. Helminthophila leucobronchialis - female with two young.- Auk, xi, I, p. 79.

1894. Remarks on the Nest of Cistothorus palustris.$A u k$, xi, I, p. 80.

1895. Aythya marila or A. m. nearctica? - Auk, xii, 3, p. 293.

1895. An apparently Undescribed Plumage of Oidemia perspicillata.-Auk, xxi, 3, p. 295.

1895. Lanius ludovicianus migrans and Tryngites subruficollis in Connecticut.-Abst. Limn. Soc., $N$. $Y$., viii, p. 4.

1899. Loggerhead Shrike at New Haven.-Abst. Linn. Soc., N. Y., xi, p. 5 .

1899. Series of Brewster's Warblers taken near New Haven.-Abst. Linn. Soc., N. Y., xi, p. 7.

1900. Catbird taken at Guilford, Jan. 24, 1900.-Abst. Linn. Soc., N. Y., xii, p. 7 .

190I. Rachitis in Young Red-shouldered Hawks.-Auk, xviii, 2, p. I92.

I90I. The European Starling in Connecticut. Auk, xviii, 2, p. 194.

I90I. Acanthis linaria rostrata and Xanthocephalus xanthocephalus in Connecticut.-Auk, xviii, 2, p. 195 .

1901. Deformity of Maxilla in the House Sparrow.Auk, xviii, 2, p. 195.

I90I. The Winter Birds of Pea Island, North Carolina.Auk, xviii, 3, pp. 260-268.

I901. A new Sharp-tailed Finch from North Carolina.Auk, xviii, 3, pp. 269-27o.

I902. Migration at New Haven.-Abst. Linn. Soc., N. $Y$. xiii, pp. 4-5. 
1902. Starling taken at New Haven, Dec. 3, r9o0.Abst. Linn. Soc., N. Y., xiii, p. 6.

1902. Greater Redpoll etc. at New Haven.-Abst. Linn. Soc., N. Y., xiii, p. 6.

1902. Winter Records in Connecticut.-Abst. Linn. Soc., $N$. $Y$., xiv, p. Io.

1902. The Summer Birds of Warren, Conn.-Abst. Linn. Soc., N. Y., xiv, p. II.

1902. Barred Owl's and Red-shouldered Hawk's Eggs in the same Nest.-Abst. Linn. Soc., N. Y., xiv, p. I2.

1903. The Water-Fowl Family.

1904. Barred Owl and Red-shouldered Hawk laying in the same Nest for two Years.-Abst. Linn. Soc., $N . Y ., \mathrm{xv}, \mathrm{p} .4$.

1905. The Status of Helminthophila leucobronchialis and Helminthophila lawrencei.-Auk. xxii, I, pp. 2I-24.

1905. The Direction of Flight in the Fall Migration at New Haven, Conn.-Auk, xxii, 4, pp. 372-378.

1906. Notes from Connecticut.-Auk, xxiii, 3, p. 344 .

I907. Short-eared Owl and Holbœll's Grebe in Connecticut.-Abst. Linn. Soc., N. Y., xvii, p. 9.

1907. Direction of Flight in Fall Migration at New Haven, and Notes from Connecticut.-Abst. Linn. Soc., N. Y., xvii, p. 9.

1908. List of the Birds of the New Haven Region.New Haven Bird Club, Bull. I.

I910. Two New Sub-species of North American Birds.Auk, xxvii, I, pp. 59-63.

I9Io. Notes from Connecticut.-Auk, xxvii, 4, p. 462.

Bonaparte, Charles Lucien J. L.- See Wilson, Alexander.

Bonner, Mrs. Paul R.

1907. Notes on the Starling.-Bird-Lore, ix, 4, pp: I7II72.

1907. Trapping English Sparrows.-Bird-Lore, ix, 5 pp. 2II-2I3. 
Brandegee, Robert B.

1893. The Birds of Berlin [Conn.].-Berlin Nerws, iii, 2, p. 2.

1893. The Hawks of Berlin [Conn.].-Berlin News, iii, 4.

1908. The Farmington Mountain Reservation.-BirdLore, x, 4, p. -19I.

Brewer, Thomas M., M.D.

1856. Raptores and Fissirostres.-Smithson. Contrib. to Knowledge. North American Oölogy, Part I.

1869. Seaside Ornithology.-Am. Nat., iii, 5, pp. 225-235. 1875. Catalogue of the Birds of New England.-Proc. Bost. Soc. Nat. Hist., xvii, pp. 436-454.

1878. Notes on Certain Species of New England Birds, with additions to his Catalogue of the Birds of New England.-Proc. Bost. Soc. Nat. Hist., xix, pp. 301-309.

1879. Some additional notes upon Birds observed in New England.-Proc. Bost. Soc. Nat. Hist., xx, pp. 263-277.

1880. Blue-winged Yellow Warbler in New England.Bull. Nutt. Orn. Club, v, I, p. 48.

- See also Baird, Spencer F.

Brewster, C. E.-See Oldys, Henry; Palmer, T. S.

\section{Brewster, William.}

1877. Merriam's "Review of the Birds of Connecticut." - Bull. Nutt. Orn. Club, ii, 4, p. 107.

I884. Description of the female of Helminthophaga leucobronchialis.-Auk, i, I, p. 9 I.

1895. Minot's "The Land Birds and Game Birds of New England." Second Edition.

1895. A Remarkable Flight of Pine Grosbeaks.-Auk, xii, 3, pp. 245-256.

See also Minot, H. D.

Brockway, Arthur W.

I898. The Turkey Vulture in Connecticut.- $A u k, \mathrm{xv}, \mathrm{I}$, p. 53 .

1898. Carolina Wren at Lyme, Conn.-Auk, xv, 2, p. I92. 
I898. Carolina Wren at Lyme, Conn.-Auk, xv, 3, p. 274.

I899. The Little Blue Heron in Connecticut.-Auk, xvi, 4, p. $35 \mathrm{I}$.

1899. Odd Nesting of Maryland Yellow-throat.-Auk, xvi, 4 , p. 360 .

1909. Spring Migration at Hadlyme--Hartford Times, June 7.

1910. A Carolina Wren in New London County, Conn.Auk, xxvii, 2, p. 213.

Brown, Nathan Clifford.

1882. An Addition to the Maine Fauna.-Bull. Nutt. Orn. Club, vii, I, p. 60.

1882. The King Rail in New England.-Bull. Nutt. Orn. Club, vii, 2, p. I24.

Browne, F. C.

1887. The New England Glossy Ibises of I850.-Auk, iv, 2, pp. 97-100.

Bruen, Frank.

1902. Some Bluebird Boxes and Troubles.-Wilson Bulletin, No. 4I, xiv, 4, pp. I2I-I23.

1902. Winter Birds of Bristol, Conn., and Vicinity.Wilson Bulletin, No. 4I, xiv, 4, p. 132.

I903. The New Year's Day Bird Census at Bristol. Wilson Bulletin, No. 42, xv, I, p. 27.

1904. The New Year's Day Bird Census at Bristol.Wilson Bulletin, No. 46, xvi, I, p. I6.

1905. Transplanting a Robin.-Wilson Bulletin, No. 50, xvii, I, p. 25.

1905. Moving a Wren's Home.-Wilson Bulletin, No. 50, xvii, I, p. 26.

1907. Notes from Bristol, Conn.-Wilson Bulletin, No. $6 \mathrm{I}, \mathrm{xix}, 4$, p. 162.

Buck, Henry R.

1893. A Nest of Hen Hawks.-O. and O., xviii, Io, pp. I $33^{-1} 35$. 
I894. An Oölogist of Early Day. -Oölogist, xi, Io, p. 305.

1896. The Breeding of Warbling and Yellow-throated Vireos.-Wilson Bulletin, No. II, pp. 4-5.

1897. Nest built by Ospreys near Hartford, Conn.Osprey, i, Io, p. I30.

1897. An Osprey's Nest at Hartford, Conn.-Osprey, i, II-I2, p. I49.

I898. An Elusive Pair of Screech Owls.-Wilson Bulletin, No. 23, x, 6, pp. 76-77.

Burns, Frank L.

1895. The American Crow.-Wilson Bulletin, No. 5.

1900. A Monograph of the Flicker (Colaptes auratus). -Wilson Bulletin, No. 31, xii, 2, pp. I-82.

I9I I. A Monograph of the Broad-winged Hawk (Buteo platypterus).-Wilson Bulletin, Nos. 76, 77 , xxiii, 3, 4, pp. I-320.

Burr, F. L.

1896. The Baltimore Oriole.-The Observer, vii, 5, pp. 2I 5-217.

Burr, Freeman F.

1908. List of Birds of the New Haven Region.- New Haven Bird Club, Bull. I.

Buttrick, P. L.

I907. The Starling at Stonington and New Haven, Conn. - Bird-Lore, ix, 5, p. 208.

1908. List of the Birds of the New Haven Region.New Haven Bird Club, Bull. I.

1909. Observations on the Life History of the Bobolink. -Bird-Lore, xi, 3, p. 125.

C., G. R.- See Case, George R.

Cabot, Samuel, Jr., M.D.

185I. Ibis guarauna taken at Middletown, Conn.-Proc. Boston Soc. Nat. Hist., iii, p. 3 I4.

Canfield, J. B.

1895. The Red Phalarope at Bridgeport, Conn.-Auk, xii, I, p. 77 . 
1897. A Nest within a Nest.-Oölogist, xiv, 6, p. 58 .

1902. Blue-winged Warbler.-Am. Ornith., ii, pp. 52-55.

1902. Louisiana Water-Thrush.-Am. Ornith., ii. pp. $225^{-227}$.

Capen, Elwin A.

1886. Oölogy of New England.

Carpenter, Frederic $\mathrm{H}$.

1886. Regarding the Pileated Woodpecker in Connecticut. -O. and $0 ., \mathrm{xi}, 3, \mathrm{p} .48$.

Case, Rev. Bert Francis.

1905. Notes on Winter Feeding at Middle Haddam, Conn.-Bird-Lore, vii, 5, p. 242.

1906. An Experience in Tree-top Photography.-BirdLore, viii, I, pp. I-6.

Case, Clifford M.

1896. Solitary Vireo Nesting in Connecticut.-Auk, xiii, 4, p. 343.

1905. Rough-winged Swallow at Hartford, Conn.Oölogist, xxii, 7, p. 108.

1905. Red-tailed Hawk-Oölogist, xxii, 7, p. I08.

1907. City Birds.-Oölogist, xxiv, 4, p. 57.

Case, George R.

I882. Blue Yellow-backed Warbler-O O and O., vii, I6, pp. I24-125.

1883. Field Glass.- $O$. and 0 ., viii, I, pp. 5-6.

Cassin, John. - See Baird, Spencer F.

Census, The Christmas Bird - Connecticut.

Igor. Bird-Lore, iii, I, p. 30.

1902. Bird-Lore, iv, I, p. 26.

I903. Bird-Lore, v, I, pp. I5-I6.

1904. Bird-Lore, vi, I, pp. IO-II.

1905. Bird-Lore, vii, I, p. 25.

1906. Bird-Lore, viii, I, pp. I6-17.

1907. Bird-Lore, ix, I, pp. 2I-23.

1908. Bird-Lore, x, I, pp. 26-27.

1909. Bird-Lore, xi, I, pp. 20-22. 
1910. Bird-Lore, xii, I, pp. 23-24.

I9r. Bird-Lore, xiii, I, pp. 23-25.

1912. Bird-Lore, xiv, I, pp. 23-24.

Chadbourne, Arthur P., M.D.

1889. An Unusual Flight of Killdeer Plover along the New England Coast.-Auk, vi, 3, pp. 255-263.

Chamberlain, Montague.

1891. Nuttall's Ornithology of Eastern North America. Revised and Annotated.

Chapman, Frank M.

I892. A Preliminary Study of the Grackles of the Subgenus Quiscalus. Author's Edition. [From Bull. Am. Mus. Nat. Hist., iv, r, p. 20.]

1894. Visitors' Guide to the Collection of Birds Found within Fifty Miles of New York City.

1895. Handbook of Birds of Eastern North America.

1898. Sage's "List of Portland, Conn., Birds."-Auk, xv, 3, p. 284.

1899. Sparrow-proof Houses.-Bird-Lore, i, 2, p. 60.

1900. The Season's Flight of Crossbills.-Bird-Lore, ii, I, p. 25 .

1900. Additional Notes on the Season's Flight of Crossbills.-Bird-Lore, ii, 2, p. 59.

1900. A study of the Genus Sturnella.-Bull. Am. Mus. Nat. Hist., xiii, 22, pp. 297-320.

190I. A Nighthawk Incident.-Bird-Lore, iii, 4, p. 126. 1903. Color Key to North American Birds.

1906. The Birds of the Vicinity of New York City.Am. Mus. Jour., vi, 2, 3. Reprint, pp. I-96.

1907. The Warblers of North America.

1909. Carolina Wren in Connecticut.-Bird-Lore, xi, I, p. I5.

1912. Handbook of Birds of Eastern North America. Revised Edition.

Clark, John N.

I88I. Hooded Warblers Nesting in Southern Connecticut. -O. and $O$., vi, 2, pp. 9-10. 
I88I. Little Blue Heron (Note).- O. and O., vi, 7, p. 5 I. 188I. Red-headed Woodpecker in Southern Connecticut. -O. and O., vi, 9, p. 72 .

1882. Hooded Warbler Nesting in Southern Connecticut. - O. and O., vii, I3, p. 102.

1882. Great Horned Owl's Nest and Eggs.- O. and O., vii, I6, pp. 125-126.

1882. Nesting Habits - Woodcock and Black Duck.$O$. and $O$., vii, p. 144 .

1882. Large-billed Water-Thrush.-O. and O., vii, I9, pp. I45-I47.

1882. Great White Egret in Connecticut.-O. and 0 ., vii, 24, p. 189.

1882. Eggs of Yellow-billed and Black-billed Cuckoos in the same Nest.-O. and O., vii, 24, p. I89.

I882. Red-Shouldered Hawk.- O. and O., vii, 24, p. I89. I883. Clark on "Gull Island."-O. and O., viii, 3, p. 2 I. 1883. Blue-winged Yellow Warbler nesting in Connecticut.- $O$. and $O$., viii, 5 , pp. 37-38.

I883. Hairy Woodpecker.-O and O., viii, Io, pp. 77-78. 1883. Curious Nesting of a Blue Jay.-O. and O., viii, Io, p. 78.

I883. Blue Jays Tame.-O. and O., viii, Io, p. 78. I883. Winter Birds.- O. and O., viii, ro, p. 80. 1884. Nesting of the Little Black Rail in Connecticut.$A u k$, i, 4, p. 393.

1884. A Prolific Pair of Song Sparrows.-Random Notes on Nat. Hist., i, Io, p. 3.

1884. Notes on the Sharp-shinned Hawk-Random Notes on Nat. Hist., i, I2, p. Io.

1884. The Screech Ow1.-O. and O., ix, 5, p. 6I. 1885. Helminthophila leucobronchialis at Saybrook.Random Notes on Nat. Hist., ii, 6, p. 43.

1885. Tennessee Warbler at Saybrook.-Random Notes on Nat. Hist., ii, 9, p. 67.

1885. Successful Rearing of some Young Dusky Ducks. - Random Notes on Nat. Hist., ii, 12, p. 93. 1886. Immaculate Eggs of Song Sparrows.-Random Notes on Nat. Hist., iii, I, p. 8. 
1886. Constancy of a Male Oriole.-Random Notes on Nat. Hist., iii, 12, p. 98.

1887. Nesting of the Black-throated Green Warbler.$O$. and 0. xii, 2, pp. 22-23.

1887. A Favorite Nest [Nest occupied in successive stories by two species of owls and two of hawks].-O. and O., xii, 8, p. I35.

1887. The Number of Eggs in a Set of certain Species.0 . and 0 ., xii, Io, p. I73.

I888. The Corn Crake in Connecticut.-O and O., xiii, 3 , pp. $45-46$

I888. Nest Building.-O. and O., xiii, 9, p. I4I.

I889. A Swallow-tailed Kite at Saybrook, Conn.-O. and O., xiv, 8, p. 123 .

I889. The Effect of a Storm on Birds.-O. and O., 'xiv, 3, pp. $35-36$.

1889. The White-throated Warbler at Saybrook, Conn.$O$. and 0. , xiv, 8, p. I 19.

I890. Nesting of the Yellow-throated Vireo.- 0 . and $O$., xv, 5, pp. 69-7o.

1890. Albino Sparrow, etc., at Saybrook.-O. and O., xv, I2, p. 188.

189r. A Crazy Bluebird.-O. and O., xvi, 2, p. 24.

1892. Nesting of the Sharp-shinned Hawk.-O. and O., xvii, 2, pp. 27-28.

1892. True Politeness [Habits of the Cedar Bird]. - The Observer, iii, Io, pp. 305-307.

1893. The First Spring Outing.-O. and O., xviii, I, pp. I-2.

1893. Queer Occupant of a Goldfinch's Nest.-O. and O., xviii, 4, pp. $5^{\mathrm{I}-52}$.

1895. Summer Redbird at Saybrook, Conn.-Auk, xii, 3 , p. 306 .

1902. Nesting of the Great Carolina Wren in Connecticut. - Auk, xix, I, p. 90.

Clulee, H. L.

1885. Purple Grackle and Kingfisher at Wallingford in December.-Random Notes on Nat. Hist., ii, 3, p. 18 . 
Coe, W. W.

1878. Spring Notes [at Portland, Conn.].-Forest and Stream, x, pp. 68-69.

1882. Curious Nesting Places.-O. and O., vii, 23, pp. 183-184.

1883. Barred Owls and Canada Goose.-O. and O., viii, I, p. 3 .

1883. Canada Buntings (Snowflakes) at Portland.$O$. and $O$., viii, I, p. 4 .

1883. Great Horned Owl.-O. and O., viii, 2, p. I4.

1883. Bluebirds at Portland, Dec. 31st, 1882.-O. and $O$., viii, 3, p. 23.

1883. Kingfisher Shot at Portland, Jan. 14th, 1883.$O$. and $O$., viii, 3, p. 24.

- 1883. Wild Goose Shot Jan. 4th near Middletown.-O. and $O$., viii, 3, p. 24.

1883. Set of Great Horned Owl's Eggs, March 4th, i883. $-O$. and $O$., viii, 6, p. 45 .

Colbron, E. K.

1888. Yellow-Headed Blackbird in Connecticut.-O. and O., xiii, 12, p. 189.

Cole, Prof. Leon J.

1909. The Tagging of Wild Birds, as a Means of Studying their Movements.-Auk, xxvi, 2, pp. 137I43.

1910. American Bird-banding Association.-Wilson Bulletin, No. 7o, xxii, I, pp. 53-55.

Comstock, William I.

1889. Connecticut Notes.-Oölogist, vi, I2, p. 23 I.

1890. Connecticut Notes. - Phobe's Nest with Five Cowbird's Eggs.-Oölogist, vii, 7, p. I4I.

1892. The Vireos of Connecticut.-Oölogist, ix, 3, p. 76. 1905. Another Large Set of Hawks [Eggs].-Oölogist, xxii, II, p. 168.

Connecticut Audubon Society [Mabel (Osgood) Wright, President; Helen W. Glover, Secretary].

1899. Organization.-Bird-Lore, i, I, p. 30.

1899. Second Annual Meeting.-Bird-Lore, i, 4, p. I39. 
1900. Annual Report.-Bird-Lore, ii, 5, p. 165. I90I. Annual Report.-Bird-Lore, iii, 5, p. I8I. I903. Annual Report.-Bird-Lore, v, i, p. 40. 1905. Annual Report.-Bird-Lore, vii, I, p. 77. 1905. Annual Report.-Bird-Lore, vii, 6, p. 312. I906. Annual Report.-Bird-Lore, viii, 2, p. 77. I906. Annual Report.-Bird-Lore, viii, 6, p. 25 I. 1907. Annual Report.-Bird-Lore, ix, 6, p. 330. 1908. Annual Report.-Bird-Lore, x, 6, p. 297. 1909. Annual Report.-Bird-Lore, xi, 6, p. 308. 1910. Annual Report.-Bird-Lore, xii, 6, p. 285.

I9I I. Annual Report.-Bird-Lore, xiii, 6, pp. 364-365.

\section{Cooke, Wells W.}

1903. Some New Facts about the Migration of Birds.-

U. S. Dept. Agriculture, Year Book, pp. 37 I-386.

I903. The Migration of Warblers - American Redstart.

-Bird-Lore, v, 6, p. 189.

I904. Distribution and Migration of North American

Warblers.-U. S. Dept. Agriculture, Div. Biol.

Surv., Bull. I8.

1904. The Migration of Warblers-Yellow-breasted Chat.-Bird-Lore, vi, I, p. 23.

1904. The Migration of Warblers-Black-throated Green

Warbler.-Bird-Lore, vi, 2, pp. 57-58.

I904. The Migration of Warblers - Wilson's Warbler.Bird-Lore, vi, 2, p. 58.

1904. The Migration of Warblers - Canadian Warbler.

Bird-Lore, vi, 2, p. 59.

1904. The Migration of Warblers - Blue-winged Warbler.-Bird-Lore, vi, 3, p. 9 I.

1904. The Migration of Warblers - Golden-winged Warbler.-Bird-Lore, vi, 3, p. 92.

1904. The Migration of Warblers - Chestnut-sided Warbler.-Bird-Lore, vi, 5, p. 163 .

1904. The Migration of Warblers - Magnolia Warbler.

-Bird-Lore, vi, 6, p. 200.

1905. The Migration of Warblers - Yellow Warbler.Bird-Lore, vii, I, p. 32 . 
1905. The Migration of Warblers - Prairie Warbler.Bird-Lore, vii, I, p. 34 .

1905. The Migration of Warblers - Connecticut Warbler. - Bird-Lore, vii, 2, p. I36.

1905. The Migration of Warblers - Black and White Warbler.-Bird-Lore, vii, 4, p. 203.

1905. The Migration of Warblers - Black-poll Warbler. -Bird-Lore, vii, 4, p. 205.

1905. The Migration of Warblers - Nashville Warbler. -Bird-Lore, vii, 5, p. 237.

1905. The Migration of Warblers - Yellow Palm Warbler.-Bird Lore, vii, 6, p. 276.

1905. The Migration of Warblers - Maryland Yellowthroat.-Bird-Lore, vii, 6, p. 277.

1906. The Migration of Warblers - Worm-eating Warbler.-Bird-Lore, viii, I, p. 27.

I906. The Migration of Warblers - Myrtle Warbler.Bird-Lore, viii, 2, pp. 61-62.

1906. The Migration of Warblers - Oven-bird.-BirdLore, viii, 3, p. 100.

1906. The Migration of Warblers - Northern WaterThrush.-Bird-Lore, viii, 3, p. Ior.

1906. The Migration of Warblers - Louisiana WaterThrush.-Bird-Lore, viii, 3, p. I02.

1906. The Migration of Warblers - Northern Parula Warbler.-Bird-Lore, viii, 5, pp. I68-I69.

1906. The Migration of Warblers - Black-throated Blue Warbler.-Bird-Lore, vi, 6, p. 203.

1906. Distribution and Migration of North American Ducks, Geese, and Swans.-U. S. Dept. Agriculture, Div. Biol. Surv., Bull. 26.

1907. The Migration of Thrushes - Wood Thrush.Bird-Lore, ix, I, p. 32.

1907. The Migration of Thrushes - Wilson's Thrush.Bird-Lore, ix, I, p. 33 .

1907. The Migration of Thrushes - American Robin.Bird-Lore, ix, 2, p. 76.

1907. The Migration of Thrushes - Hermit Thrush.Bird-Lore, ix, 3, p. I23. 
I908. The Migration of Flycatchers - Least Flycatcher. - Bird-Lore, x, 3, p. II7.

I908. The Migration of Flycatchers - Kingbird.-BirdLore, x, 4, p. 166.

1908. The Migration of Flycatchers - Wood Pewee.Bird-Lore, x, 4, p. 168 .

1908. The Migration of Flycatchers - Phobe-BirdLore, $\mathrm{x}, 5$, pp. 2 IO-2II.

1909. The Migration of Flycatchers-Crested Flycatcher.-Bird-Lore, xi, I, pp. I2-I3.

I909. The Migration of Vireos - Philadelphia Vireo.Bird-Lore, xi, 2, p. 78.

I909. The Migration of Vireos - Warbling Vireo.Bird-Lore, xi, 2, pp. 79-80.

1909. The Migration of Vireos-Red-eyed Vireo.Bird-Lore, xi, 2, pp. 8I-82.

1909. The Migration of Vireos - White-eyed Vireo.Bird-Lore, xi, 3, p. II8.

I909. The Migration of Vireos - Yellow-throated Vireo. -Bird-Lore, xi, 4, p. 165.

I909. The Migration of Vireos - Blue-headed Vireo.Bird-Lore, xi, 4, p. 167.

1909. The Migration of North American SparrowsTree Sparrow.-Bird-Lore, xi, 6, p. 255.

1909. The Migration of North American Sparrows Chipping Sparrow.-Bird-Lore, xi. 6, pp. 256257.

1909. The Migration of North American Sparrows Field Sparrow.-Bird-Lore, xi, 6, pp. 258-259.

I910. The Migration of North American Sparrows -

Grasshopper Sparrow.-Bird-Lore, xii, I, p. I3.

1910. The Migration of North American Sparrows Henslow's Sparrow.-Bird-Lore, xii, I, p. I4.

1910. The Migration of North American SparrowsSong Sparrow.-Bird-Lore, xii, 2, p. 67.

I9I0. The Migration of North American SparrowsSharp-tailed Sparrow.-Bird-Lore, xii, 3, p. II I. I910. The Migration of North American Sparrows Nelson's Sparrow.-Bird-Lore, xii, 3, p. II2. 
19ro. The Migration of North American SparrowsAcadian Sharp-tailed Sparrow.-Bird-Lore, xii, 3, p. II2.

I9ro. The Migration of North American Sparrows Seaside Sparrow.-Bird-Lore, xii, 3, p. Ir2.

I9I0. Distribution and Migration of North American Shore-birds.- U. S. Dept. Agriculture, Biol. Surv., Bull. 35 .

I9II. The Migration of North American SparrowsVesper Sparrow.-Bird-Lore, xiii, 2, pp. 86 and 88.

I9II. The Migration of North American Sparrows Savannah Sparrow.-Bird-Lore, xiii, 3, pp. I44 and 146.

I9I I. The Migration of North American Sparrows Indigo Bunting.-Bird-Lore, xiii, 4, pp. I99-20I.

I9I I. The Migration of North American Sparrows Evening Grosbeak.-Bird-Lore, xiii, 6, p. 299. I9Ir. The Migratory Movements of Birds in Relation to the Weather.-U. S. Dept. Agriculture, Yearbook for I910, pp. 377-390.

1912. The Migration of North American SparrowsWhite-winged Crossbill.-Bird-Lore, xiv, I, p. 47.

1912. The Migration of North American Sparrows White-crowned Sparrow.-Bird-Lore, xiv, 2, pp. 98-99.

1912. The Migration of North American Sparrows White-throated Sparrow.-Bird-Lore, xiv, 2, pp. IOI, IO3-IO4.

1912. The Migration of North American Sparrows Rose-breasted Grosbeak.-Bird-Lore, xiv, 3, pp. I59 and I6r.

1912. The Migration of North American Sparrows Towhee.-Bird-Lore, xiv, 5, pp. 287 and 289.

1912. The Migration of North American Sparrows Pine Grosbeak.-Bird-Lore, xiv, 6, pp. 345-346. I913. The Migration of North American Sparrows Snow Bunting.-Bird-Lore, xv, I, pp. I6-I7. 
1913. The Migration of North American Sparrows Fox Sparrow.-Bird-Lore, xv, 2, pp. 105-107.

19I3. Distribution and Migration of North American Herons and their Allies.-U. S. Dept. Agriculture, Biol. Surv., Bull. 45 .

Cory, Charles B.

1897. How to Know the Shore-birds.

1897. How to Know the Ducks, Geese, and Swans.

1899. The Birds of North America known to Occur East of the Ninetieth Meridian. Part I. Water Birds. Part II. Land Birds.

Coues, Elliott, M.D.

I868. Catalogue of the Birds of North America contained in the Museum of the Essex Institute, with which is incorporated a List of the Birds of New England.-Proc. Essex Inst., v, 33, pp. 249-3I4.

1868. A List of the Birds of New England [Reprinted from Proc. Essex Inst.], pp. 7I.

1872. Key to North American Birds.

I874. Birds of the Northwest.-U. S. Geol. Surv. Terr., Misc. Pub. No. 3 .

I878. Birds of the Colorado Valley.-U. S. Geol. Surv. Terr., Misc. Pub. No. II.

188I. New England Bird Life. Part I. Oscines. I883. New England Bird Life. Part II. Non-Oscine Passeres, Birds of Prey, Game and Water Birds I884. Key to North American Birds. Second Edition, revised to date.

1903. Key to North American Birds. Fifth Edition, entirely revised.

Cressy, Nettie S.

I9I I. Mockingbird at West Hartford - Winter I9Io-I I. - Hartford Times, Feb. 7.

Davie, Oliver.

1898. Nests and Eggs of North American Birds. Fifth Edition. 


\section{Deane, Ruthven.}

1880. Large-billed Water-Thrush in Connecticut.-Bull. Nutt. Orn. Club, v, 2, p. I16.

1880. Hooded Warbler in Connecticut.-Bull. Nutt. Orn. Club, v, 2, p. II 7 .

I881. Breeding of Wild Pigeons in Confinement [in Connecticut].-Bull. Nutt. Orn. Club, vi, I, p. 6 o. 1902. Unusual Abundance of the Snowy Owl in New England and Canada.-A - $ı$, xix, 3, pp. 276277.

1906. Unusual Abundance of the Snowy Owl.-Auk. xxiii, 3, p. 29 r.

1907. The Snowy Owl not generally abundant in the Winter of 1906-7.-Auk, xxiv, 2, p. 217.

1907. Unusual Abundance of the American Goshawk. - Auk, xxiv, 2, p. I83.

De Kay, James E.

1844. Natural History of New York. Zoölogy of New York. Part II. Birds.

Dow, Everett D.

1912. Hooded Warbler at Hartford, Conn.-Bird-Lore, xiv, 4, p. 230.

Dugmore, A. Radclyffe.

1900. The Nests, Eggs, and Breeding Habits of the Land Birds breeding in the Eastern United States.

Dunbar, W. L.

I888. Red-eyed Vireo.-Oölogist, v, IO-I I, p. 158.

1893. Nesting of the Blue-winged Yellow Warbler.Oölogist, x, 4, p. I Io.

Dutcher, William.

rgor. Protection of Gulls and Terns in Connecticut.Auk, xviii. I, pp. 84-86.

1902. Protection of Gulls and Terns in Connecticut.Auk, xix, I, p. 39.

1903. Protection of Gulls and Terns in Connecticut.Auk, xx, I, p، II7.

1904. Food of Screech Owl.-Bird-Lore, vi, 5, p. I80. 
1905. Game Legislation in Connecticut.-Bird-Lore, vii, 3 , p. 183 .

1907. Game Legislation in Connecticut.-Bird-Lore, ix, I, p. 54 .

1907. Game Legislation in Connecticut.-Bird-Lore, ix, 2, p. IOI.

1907. Game Legislation in Connecticut.-Bird-Lore, ix, 3 , p. 140 .

1907. Game Legislation in Connecticut.-Bird-Lore, ix, 4, p. 188.

1907. Close and Open Seasons for Wood Ducks in 1907. -Bird-Lore, ix, 4, p. I92, I plate.

1908. Bird Refuges [in Connecticut].-Bird-Lore, $\mathrm{x}, 3$, p. 145 .

1908. Leasing of Willow Island, Conn.-Bird-Lore, $\mathrm{x}$, 4, p. I9I.

I909. Willow Island Fund.-Bird-Lore, xi, I, p. $5^{8}$. 1909. Legislation in Connecticut-Bird-Lore, xi, 3, p. 146.

\section{Dwight, Jonathan, Jr., M.D.}

1887. Ammodramus caudacutus subvirgatus taken at Madison, Conn., on June 9th.-Auk, iv, 3, p. 236.

1890. The Horned Larks of North America.-Auk, vii, 2, pp. I4I-I 42.

1906. Status and Plumages of the White-winged Gulls of the Genus Larus.-Auk, xxiii, I, p. 37.

1907. A Sketch of the Thrushes of North America.Bird-Lore, ix, 3, pp. I03-Iog.

Eames, Dr. Edwin H.

1888. Notes on Helminthophila leucobronchialis.-Auk, v, 4, p. 427.

1888. Dendroica cerulea at Seymour, Conn.-Auk, v, 4, p. $43 \mathrm{I}$.

1889. The Blue-winged Warbler and its Allies in Connecticut.-Auk, vi, 4, pp. 305-3Io.

1889. The Fish Crow in Connecticut.-Auk, vi, 4, p. 338. 
I890. Food and Habits of the Ruby-throated Hummingbird.-Auk, vii, 3, p. 286-288.

1893. Notes from Connecticut.-Auk, x, I, p. 89.

Earnshaw, Frank L.-See Oldys, Henry.

Eaton, Elon Howard.

1910. Birds of New York, Part I.-New York State Museum, Memoir 12.

Edwards, Stanley W.

1903. Yellow-billed Cuckoo's Egg in a Robin's Nest.$A u k, \mathrm{xx}, \mathrm{r}, \mathrm{p} .68$.

Elliott, Daniel Giraud, D.Sc.

1895. North American Shore-Birds.

1897. The Gallinaceous Game Birds of North America.

1898. The Wild Fowl of the United States and British Possessions.

Ells, George P.

1907. The Starling at Norwalk, Conn.-Bird-Lore, ix, 5 , p. 207.

Faxon, Walter.

1889. On the Summer Birds of Berkshire County, Mass.

(Several references to Connecticut Species.) Auk, vi, I, pp. 39-46.

19II. Brewster's Warbler.-Mem. Mus. Comp. Zoöl., xi, 2, pp. $57-78$, I plate.

Fisher, A. K., M.D.

1893. The Hawks and Owls of the United States in their Relation to Agriculture.- U. S. Dept. Agriculture, Div. Orn., Bull. 3 .

Igor. Two Vanishing Game Birds.-U. S. Dept. Agriture, Yearbook, pp. 447-458, plates lxiii, lxiv.

Flagg, Wilson.

1875. The Birds and Seasons of New England.

Fleming, James $\mathrm{H}$.

1907. The Unusual Migration of Brunnich's Murre (Uria lomvia) in Eastern North America.-Proc. 
Fourth Internat. Orn. Cong., I905, pp. 528-543, plates.

Flint, H. W.

I887. The Connecticut Warbler in Connecticut.-O. and O., xii, Io, p. I76.

1888. Nesting of the Blue-winged Yellow Warbler at New Haven, Conn.-O. and O., xiii, II, p. I73. 1892. Eggs of Warblers in Collection of H. W. Flint.$O$. and $O$., xvii, 9, p. 138 .

1892. Louisiana Tanager taken at New Haven, Conn.$O$. and $O$., xvii, 12, p. 187 .

1893. Capture of the Louisiana Tanager at New Haven, Conn.-Auk, x, I, p. 86.

Forbush, Edward Howe.

1907. Game Legislation in Connecticut in 1907-BirdLore, ix, 6, p. 304.

1909. Establishing a State Ornithologist in Connecticut. -Bird-Lore, xi, 6, p. 299.

I9I I. Legislation in Connecticut in I9I1.-Bird-Lore, xiii, 6, pp. 346-347.

Foster, Lyman S.

1893. Great Blue Heron shot at Bridgeport in Jan., I884. - Abst. Linn. Soc., N. Y., v, p. 2.

1896. Capture of Hybrid Sandpiper in Connecticut.Abst. Linn. Soc., N. Y., viii, p. I.

1896. Capture of Lawrence's and Brewster's Warblers, King Rail, \&c., in Connecticut.-Abst. Linn. Soc., N.Y., viii, p. 4.

Fuller, Edward.

1891. The Barred Owl.-Oölogist, viii, 2, p. 33. I891. The Cooper's Hawk.-Oölogist, viii, 3, p. 62.

I89I. The American Osprey.-Oölogist, viii, 7, pp. 145I47.

Gates, Harry $\mathrm{T}$.

1879. Goshawk at Hartford, Dec. I3, 1878. - Familiar Sci. and Fanciers' Journal, vi, 2, p. 24. 
1879. Rough-legged Hawk (?) near Hartford in June.Familiar Sci. and Fanciers' Journal, vi, 6, p. 143. I88I. Red-headed Woodpecker at Hartford.- 0 . and $O$., vi, Io, pp. 79-80.

I883. Notes from Hartford.-O. and 0 , viii, I, p. 8. Gentry, Thomas G.

I876. Life-Histories of the Birds of Eastern Pennsylvania, Vol. I. I877, Vol. II.

1882. Nests and Eggs of Birds of the United States.

Gladwin, Charles $O$.

1876. Birds of Southern Connecticut.-Forest and Stream, vi, 8, p II6; 12, p. I80.

Goff, J. L.

1883. Nesting Notes from Connecticut.-O. and O., viii, p. 78 .

Goode, G. Brown, LL. D.

I872. A Sea Bird Inland [Alle alle at Middletown, Conn.]-Am Nat., vi, I, p. 49.

Goodwin, F. M.

I884. Lanius borealis [Lanius ludovicianus migrans] nesting at Hartland, Conn., in I88I [Hartland, Vermont. Cf. O. and O., ix, 4, p. 48].-O. and O., ix, 3, p. 35 .

Graves, Charles B., M. D.

1892. Notes on the Louisiana Water-Thrush.-The Observer, iii, 6, pp. I75-I76.

Graves, Frances M.

1907. The Starling at New London, Conn.-Bird-Lore, ix, 5, p. 209.

Grinnell, Dr. George Bird.

1875. The Frigate Bird and White Ibis in Connecticut.Am. Nat., ix, 8, p. 470.

1880. Winter in Connecticut. (Colaptes auratus and Dendroica palmarum near New Haven.) Forest and Stream, xiii, p. I05.

I90I. American Duck Shooting. 
H., C. R.

I884. White Eggs of Bluebird.-Young Oölogist, i, Io, p. I4I.

1885. Submersion of Swallows.-Young Oölogist, ii, I, p. 9.

1889. Peculiarities in Sets and Eggs of a few of our Common Birds.-Oölogist, vi, 4, p. 73.

H., G. L.-See Hawley, George L.

H., G. S.-See Hawley, George L.

Hagenaw, O. J.

I890. American Raven in Consecticut.-O. and O., xv, 10, p. 156 .

Hallock, Charles.

1877. The Sportsman's Gazetteer and General Guide.

\section{Hartford Bird Study Club.}

1909. Check-List, with Migration List, Ig09.

\section{Harvie-Brown, John A.}

1874. A Collection of North American Birds' Eggs and Skins, formed principally by, the Rev. C. M. Jones, Connecticut.-Proc. Nat. Hist. Soc. Glas-

Hausman, Leon A. gore, Dec. I, I874.

I904. A Bird-Quest.-Warbler, ii, 6, pp. 83-84.

I907. Ecenomic Value of Birds.-Oölogist, xxiv, 5, pp.

"Hawk." 70-72.

1885. Spotted Robin Eggs.-Young Oölogist, i, Io, p. I 44 .

1885. Notes from Norwich, Conn.-Young Oölogist, i, II, P. I54.

Hawley, George L. (" G. L. H.” and "G. S. H.”)

1887. Nesting of the Whip-poor-will-O O and O., xii, 9, p. 155 .

I892. Oölogical Notes.-O and O., xvii, 7, pp. IO2-IO3. 1893. Abnormal Coloring of a Song Sparrow's Egg.- 
1893. Large Eggs of the Field Sparrow.-O. and O., xviii, 6, p. 95 .

Hayden, Randolph Láwrence.

I9or. Whip-poor-will.-Am. Ornith., i, 9, p. I86.

Henshaw, Henry W.

19I0. Report of the Chief of the Biological Survey for I9I0.- U. S. Dept. Agriculture.

1912. Report of the Chief of the Biological Survey for 1912.- U. S. Dept. Agriculture.

1913. Federal Law for the Protection of Migratory Birds. - U. S. Dept Agriculture, Biol. Surv.

Hill, James $\mathrm{H}$.

1902. Connecticut Bird Notes.-Auk, xix, I, p. 93.

Hoag, Benjamin.

1897. Are Green Eggs of the Red-tailed Hawk Rare?Osprey, i, 6, p. 78.

Hoffman, Ralph.

1904. A Guide to the Birds of New England and Eastern New York.

Holbrook, Judge S. T.

1881. Notes from Norwich, Conn.-O. and O., vi, 5, pp. 30-32.

Honeywill, Alfred W., Jr.

1907. Photograph of a Saw-whet Owl at New Haven.Bird-Lore, ix, I, p. 37.

1907. Prairie Horned Larks in Connecticut.-Bird-Lore, ix, 4 , p. 174 .

I908. List of the Birds of the New Haven Region.-New Haven Bird Club, Bull. I.

Hornaday, William T, Sc.D.

I9I3. Our Vanishing Wild Life.

Howe, Reginald Heber, Jr.

I899. The Hooded Warbler at Montville, Conn.-Auk, xvi, 4, p. 360 .

1900. Rough-winged Swallow Breeding in Connecticut, and other Notes.-Auk, xvii, 4, p. 389. 
1900. An annotated list of the Birds observed along the Thames River, Conn.- The Day (New London), Nov. I, I900, p. 6.

1903. A North American Faunal Index to the "Ornithologist and Oölogist." - Contrib. to N. $A$. Ornith., i, pp. 36-38.

Howes, Paul G.

1907. The English Starling.-Oölogist, xxiv, 3, p. 44. 1907. The English Starling.-Oölogist, xxiv, 8, p. I23. 1907. Decrease of Baltimore Oriole at Stamford.Oölogist, xxiv, 9, p. I40.

I908. The Maryland Yellow-throat.-Oölogist, xxv, I, p. 5 .

1908. Notes on the Black-billed Cuckoo.-Oölogist, xxv, II, p. I7I.

1909. On Purple Grackles (Quiscalus quiscula).Oölogist; xxvi, 6, p. 94 .

1909. Notes from Southern Connecticut.-Oölogist, xxvi, 8, p. 125 .

1909. Bully for the Starling.-Oölogist, xxvi, 9, p. I52. I909. Old Nesting Site of a Colony of Robins.-Oölogist, xxvi, I I, p. 186.

1909. The Carolina Rail, Nesting near Stamford.Oölogist, xxvi, II, p. Igo.

19II. Photograph of Nest and Eggs of Carolina Rail.Oölogist, xxviii, 5, p. 90.

I9r I. Connecticut News Items.-Oölogist, xxviii, 9, pp. I5O-I 52.

I9I I. Correction.-Oölogist, xxviii, 9, p. 152.

I9I I. Accidental Death of a Sparrow.-Oölogist, xxviii, I I, pp. I69-I7o.

I9I I. Accidental Death of a Starling.-Oölogist, xxviii, II, pp. I72-I73.

I9I I. Plates of Crustacea from Stomach of a Starling.Oölogist, xxviii, I I, pp. 174-I75.

I9II. A Report on the Woodpecker.-Oölogist, xxviii, I2, pp. 194-20I. 
Hoyt, William $\mathrm{H}$.

1889. European Thrush (Turdus pilaris) and Lawrence's Warbler at Stamford.- O. and O., xiv, 3, p. 44. Huntington, Dwight W.

1903. Our Feathered Game.

I9Io. Our Wild Fowl and Waders.

Hutchins, Rev. John.

1900. The House Wren as a Depredator.-Bird-Lore, ii, 3 , p. 89.

I902. The Nesting of the Yellow-throated Vireo.-BirdLore, iv, 4, pp. I20-122.

1905. A Recent Visit of the Evening Grosbeak.-BirdLore, vii, 3, p. I73.

1907. The Feeding Habits of the Blue Jay.-Bird-Lore, ix, 2, p. 8r.

I908. Pileated Woodpecker near Litchfield, Conn.- Auk, $\mathrm{xxv}, 4$, p. 475.

Ingersoll, Ernest.

1874. Discovery of the Water-Thrush's Nest in New England.-Am. Nat., viii, 4, pp. 238-239.

I88I. Colaptes auratus, called "Yaffle" in Connecticut.Bull. Nutt. Orn. Club, vi, 3, p. I84.

Inquirer.

1886. Golden Eagle in Connecticut.-Forest and Stream, xxvii, 19, p. 362 .

J., A. W.

1891. Connecticut Shore-birds.-Am. Field, xxxv, 7, p. I5I.

Job, Rev. Herbert K.

1900. The American Egret in Connecticut.-Auk, xvii, 3, p. 294.

I90I. Photographing the Caprimulgidæ.-Osprey, v: 4, pp. 5I-54.

I901. The Pileated Woodpecker in Connecticut.- $A u k$, xviii, 2, p. 193.

I905. Wild Wings. 
1907. A Thrashing by Thrashers.-Bird-Lore, ix, 6, pp. 24I-244.

I908. The Sport of Bird Study. Appendix - List of the Birds Observed in Litchfield County, Conn.

I9I0. How to study Birds.

Jones, Rev. C. M.

1870. The Breeding Habits of Birds.-Am. Nat., iii, I, pp. $48-49$.

1876. Breeding of Black-throated Blue Warbler in Connecticut.-Bull. Nutt. Orn. Club, i, r, pp. II-I3. 1881. Henslow's Sparrow Nesting in Northern Connecticut.- 0 . and 0 ., vi, 3 , pp. I7-I8.

188I. Black-throated Blue Warbler in Connecticut.O. and O., vi, 7, pp. 49-50.

I883. A Pair of Mallards shot at Eastford, Conn.-O. and 0. viii, 4, p. 32 .

I884. The Black-throated Plue Warbler in Connecticut.-O. and O., ix, 3, pp. 30-3I.

1886. The Connecticut Warbler.- 0 . and $0 ., \mathrm{xi}, 3, \mathrm{pp}$. 43-44.

1887. Nesting of Blue-headed Vireo.-O. and 0., xii, 2, p. 26.

I887. Secured a Pure Albino Robin.-0. and 0., xii, 8, p. I34.

1888. The White-breasted Nuthatch.- 0 . and 0 ., xiii, 4, pp. 57-58.

1891. Singular Capture of a Black-throated Diver.- $O$. and $O .$, xvi, 2, p. 20.

Jones, George C.

I884. Great Northern Diver.-O. and 0., ix, 6, p. 76.

Jones, Prof. Lynds.

1892. Report of the President for the Work of I89I on the Fringillida.-Wilson Quarterly, iv, 2, pp. $67-84$.

1900. Warbler Songs (Mniotiltide).-Wilson Bulletin, No. 30 , xii, I, pp. I-56. 
Judd, Elmer T.

1889. Climbing of a young Yellow-throated Vireo.$O$. and $O$., xiv, 8, p. 128 .

Judd, Robert S.

- 1907. The Starling at Bethel, Conn.-Bird-Lore, ix, 5, p. 207.

1908. The Prairie Horned Lark in Fairfield County, Conn.-Bird-Lore, x, 3, p. 129.

Judge, E. W., Jr.

1885. A Nest Full of Eggs.-Young Oölogist, ii,.2, p. 28.

Kimball, S. T.

1883. Song Sparrow's Nest, and Great Northern Shrike. - 0 . and $O$., viii, 2, p. 16.

Knowles, Rev. W. C.

1905. Where the Blue Jays find a Breakfast.-Bird-Lore, vii, 3 , p. 178 .

Lacey, Lottie Alvard.

1908. Redpoll Linnets.-Bird-Lore, x, I, pp. IO-I3.

1912. A Winter Oriole-Bird-Lore, xiv, 2, p. 109.

Langille, Rev. J. Hibbert.

1892. Birds in their Haunts.

Lawrence, George N. - See Baird, Spencer F.

Lincoln, C. E.

I891. Notes from Middletown, Conn.-O. and O., xvi, 9, pp. I40-I4I.

Linsley, A. M.

r887. Chipping Sparrow Nest in that of Baltimore Oriole. - Oölogist, iv, 2, p. 79.

1889. Notes on Connecticut Birds.-Oölogist, vi, I2, pp. 232-233.

1891. A Rambling Mixture from Connecticut (Henslow's Sparrow).-Oölogist, viii, 9, pp. I79-180.

Linsley, Rev. James H.

1843. A Catalogue of the Birds of Connecticut, arranged according to their Natural Families.-Am. Journ. Sci. and Arts, xliv, 2, pp. 249-274. 
1844. Additional Notes on Connecticut Birds.-Am. Journ. Sci. and Arts, xlvi, I, p. 5 I.

Lucas, W. H.

1884. Jottings from West Stratford.-Young Oölogist i, 7, p. IO3.

I887. Interesting Notes from Connecticut.-Oölogist, iv 2, p. 84 .

1889. Cape May Warbler at Bridgeport.-O. and $O$ xiv, Io, p. I6o.

1890. Woodcock at Bridgeport, Jan. 26, 1890, and othe Records. - O. and $0 ., \mathrm{xv}, 2, \mathrm{p} .31$.

1891. Florida Gallinule in Connecticut [Clapper Rail] -O. and O., xvi, IO, p. I49.

M., J. R.

I884. Black-capped Chickadee.-Young Oölogist, i, 5, p. 70.

McCook, Philip J.

1897. Capture of the Little Blue Heron in Connecticut.$A u k$, xiv, 4, p. 402.

1897. A Brown Crow [at Blackhall, Conn.].-Osprey ii, 3 , p. 40.

1905. Little Blue Heron in Connecticut.-Auk, xxii, i, p. 76 .

Martin, John A.

1884. Spotted Robin Eggs.-Young Oölogist, i, 9, p. I31.

Maynard, Charles J.

I890. Eggs of North American Birds.

1896. Handbook of the Sparrows, Finches, \&c., of New England.

1896. The Birds of Eastern North America.

Mearns, Dr. Edgar A., U. S. A.

1892. A Study of the Sparrow Hawks (Subgenus Tinnunculus) of America, with especial reference to the Continental Species (Falco sparverius Linn.).-Auk, ix, 3, pp. 252-270. 
Meeker, Jesse C. A.

1897. Nesting Habits of the Black-throated Green Warbler.-Oölogist, xiv, II, p. 99.

1899. Nesting of the Blue-winged Warbler.-Oölogist, $\mathrm{xvi}, 2$, p. 30 .

1906. A Male Golden-winged Warbler Mated with a Female Blue-winged Warbler, at Bethel, Conn. - Auk, xxiii, I, p. I04.

Meg Merrythought.

1906. Nesting of Killdeer in Northern Connecticut.Am. Ornith., vi, 7, pp. I73-I74.

Merriam, C. Hart, M.D.

1876. Passerculus princeps and Parus hudsonicus in Connecticut.-Bull. Nutt. Orn. Club, i, 2, p. 52.

1877. A. Review of the Birds of Connecticut with Remarks on their Habits.- Trans. Conn. Acad., iv, pp. I-I 50.

1878. Early Arrivals [at New Haven].-Familiar Sci. and Fanciers' Journ., v, 4, p. 72.

1878. Correction: Podiceps cristatus not a Connecticut Bird.-Bull. Nutt. Orn. Club, iii, I, p. 47.

1884. The Coming of the Robins and other Early Birds in Southern Connecticut.-Science, iv, pp. 57I-572.

1885. Preliminary Report of the Committee on Bird Migration.-Auk, ii, I, pp. 53-65.

1887. Report of the Ornithologist.-Ann. Rep. Dept. Agriculture for 1886, pp. 227-258.

1888. Report of the Ornithologist.-Ann. Rep. Dept. Agriculture for 1887, pp. 399-456.

1889. Report of the Ornithologist and Mammalogist.Ann. Rep. Dept. Agriculture for r888, pp. $477^{-}$ 536.

1898. Life Zones and Crop Zones of the United States.U. S. Dept. Agriculture, Div. Biol. Surv., Bull. Io.

I908. Decision of the Supreme Court of the United States on the Sale of Imported Game-U. S. Dept. Agriculture, Div. Biol. Survey, Circular 67. 
1908. Report of the Chief of the Bureau of Biological Survey for 1908.

1909. Report of the Chief of the Bureau of Biological Survey for Igog.

Mershon, W. B.

190\%. The Passenger Pigeon.

\section{Metcalf, Willard L.}

I909. Ruby-throated Hummingbird - Two Broods from

One Nest.-Oölogist, xxvi, ro, p. 163.

\section{Minot, Henry D.}

1877. The Land Birds and Game Birds of New England.

1877. Minot's New England Birds: Additions.-Am.

$$
\text { Nat., xi, 3, p. } 175 \text {. }
$$

I88I. Notes on the Migration of Birds [in Western Connecticut].- $4 m$. Nat., xv, pp. 870-872.

1895. The Land Birds and Game Birds of New England. Second Edition. Edited by William Brewster.

Morgan, Albert.

1907. The Starling at Wethersfield, Conn, -Bird-Lore, ix, 5 , p. 208.

1909. Two Warbler Photographs.-Bird-Lore, xi, 5, pp, 206-208.

1913. A Bird Apartment House.-Bird-Lore, xv, 3, pp. I 55-I 57 .

Morris, Robert O.

I894. Rare Visitations to the Connecticut Valley in 1893. - Auk, xi, 2, p. I8r.

I90I. The Birds of Springfield and Vicinity.

Morris, Robert T., M.D.

1876. Game Birds of Connecticut.-Forest and Stream, vii, p. I 16.

1876. Local Nomenclature [for wild fowl] on the Connecticut Coast.-Forest and Stream, vii, p. 276.

Morse, Albert P., M.D.

1897. List of Birds of Wellesley [Mass.]. 
Moulthrope, George E.

1902. The Camera against a Phœbe.-Am. Ornith., ii, pp. 338-34r.

Munson, Edward L., M.D.

1887. Notes from New Haven, Conn.-O. and O., xii, 9, p. 156 .

Munson, S. A.

1882. Golden Eagle taken near Hartford, Conn.-O. and O., vi, 12, p. 94.

Neff, Charles $\mathrm{H}$.

1883. The Great Carolina Wren in Connecticut.-Forest and Stream, xx, 8, p. 47.

1883. Winter and Spring Notes $1882-83$ (Portland, Connecticut).- Forest and Stream, xx, 19, 4, p. 364. 1883. Summer Birds in Winter.-O. and O., viii, 4, p. 32. 1883. Least Bittern Nesting at Portland.-O. and O., viii, II, p. 86.

1888. List of the Birds of Portland, Conn., and Vicinity. - Middlesex Co. Record, iv, 4, 5, 6, 7 .

I893. Baltimore Oriole at Portland, Conn., Dec. 22, I892. - O. and O., xviii, 3, p. 47.

\section{Nehrling, Henry.}

1893. Our Native Birds of Song and Beauty. Vol. i. I896. Our Native Birds of Song and Beauty. Vol. ii.

Nelson, E. W.

1904. A Revision of the North American Mainland Species of Mviarchus.-Proc. Biol. Soc. Wash., xvii, pp. 2I-50.

New Haven Ornithological Club.

I888. Founding.- 0 . and 0 ., xiii, 3, p. 47.

Norris, J. Parker.

1886. A Series of Eggs of the Red-tailed Hawk.- O. and O., xi, 5, pp. 67-69.

1886. The Relative Size of Eggs of the Red-tailed Hawk to the Parent Birds.-O. and O., xi, 8, p. II8. 
1887. A Series of Eggs of Myiodioctes mitratus.-O. and $O$., xii, I2, pp. 200-20I.

1888. A Series of Eggs of Parula americana.-O. and O., xiii, r, pp. 2-5.

1888. A Series of Eggs of Accipiter fuscus.-O. and O., xiii, 3, pp. 34-37.

1888. Sets of Barred Owl collected in Connecticut.$O$. and $O$., xiii, 3, pp. 39-40.

1888. A Series of Eggs of Accipiter cooperi--O. and O., xiii, 4, pp. $5^{1-52}$.

1889. A Series of Eggs of the American Woodcock.O. and O., xiv, 8, p. Irg.

1890. A Series of Eggs of the Nashville Warbler.$O$. and $0 ., \mathrm{xv}, 2$, pp. 23-24.

1890. A Series of Eggs of the Louisiana Water-Thrush. -O. and O., xv, 4, pp. 53-54.

I890. A Series of Eggs of the Marsh Hawk.-O. and O., $\mathrm{xv}, 5$, p. 72 .

I891. A Series of Eggs of Red-shouldered Hawk.$O$. and $O .$, xvi, I, pp. I-9.

1891. Some Curious Sets of the Baltimore Oriole's Eggs. - 0 . and 0. , xvi, 4, p. $6 \mathrm{r}$.

r89r. A Series of Eggs of the White-breasted Nuthatch. -O. and 0 ., xvi, 8, pp. 123-124.

I891. A Series of Eggs of the Maryland Yellow-throat. - O. and O., xvi, Io, pp. I50-I52.

1892. A Series of Eggs of Scarlet Tanager.-O. and O., xvii, 2, pp. 2I-22.

1892. A Series of Eggs of Ovenbird.-O. and O., xvii, 5 , pp. $65-67$.

\section{Nuttall, Thomas.}

1832. A Manual of the Ornithology of the United States and Canada. The Land Birds.

1834. A Manual of the Ornithology of the United States and Canada. The Water Birds.

I891. A Popular Handbook of the Ornithology of Eastern North America. Revised and annotated by Montague Chamberlain. 
Oberholser, Harry C.

1902. A Review of the Larks of the Genus Otocoris.Proc. U.S. Nat. Mus., xxiv, pp. $801-884$, plates xliii-xlix.

1904. A Revision of the American Great Horned Owls.Proc. U.S. Mus., xxvii, pp. 177-192.

1904. A Review of the Wrens of the Genus Troglodytes. - Proc. U.S. Nat. Mus., xxvii, pp. 197-210.

1906. The North American Eagles and their Economic Relations.-U. S. Dept. Agriculture, Div. Biol. Surv., Bull. 27.

I9II. A Revision of the Forms of the Hairy Woodpecker, Dryobates villosus (Linnæus).-Proc. U. S. Nat. Mus., xl, pp. 595-621.

1912. A Revision of the Subspecies of the Green Heron, Butorides virescens (Linnæus).-Proc. U. S. Nat. Mus., xlii, pp. 529-577.

1912. A Revision of the Forms of the Great Blue Heron, Ardea herodias Linnæus.-Proc. U. S. Nat. Mus., xliii, pp. 531-559.

Observer, An.

1891. American Sparrow Hawk.-Oölogist, viii, I, p. 6. I891. Hermit Thrush.-Oölogist, viii, 4, 5, pp. 9I-92.

Olds, H.-See Palmer, T. S.

Oldys, Henry.

1908. Game Protection in 1907.-U. S. Dept. Agriculture, Yearbook for 1907, pp. 590-597.

19ro. Introduction of the Hungarian Partridge into the United States.-U. S. Dept. Agriculture, Yearbook for 1909, pp. 249-258.

Oldys, Henry, Brewster, C. E., and Earnshaw, Frank L. 1910. Game Laws for rgro.-U. S. Dept. Agriculture, Farmers' Bull. 4I8.

Palmer, C. H.

1905. Winter Birds seen from a Window.-Am. Ornith., v, 5, pp. 104-106. 
Palmer, Dr. Theodore S.

I899. Report of the Acting Chief of the Division of Biological Survey for I899.- Report of Sec. of Agriculture, pp. 59-70.

1900. Legislation for the Protection of Birds other than Game Birds. - U. S. Dept. Agriculture, Div. Biol. Surv., Bull. I2.

I900 - I912.. Directory of Officials and Organizations concerned with the Protection of Birds and Game.-U. S. Dept. Agriculture, Div. Bio!. Surv., Circulars 28, 33, 50, 53, 62, 65, 70, 74 , 83,88 .

1904. Hunting Licenses.- U. S. Dept. Agriculture, Div. Biol. Surv., Bull. I9.

1904. Game Protection in I904.- U. S. Dept. Agriculture, Yearbook, pp. 606-6io.

1905. Recommendations of State Game Commissioners and Wardens for 1905.-U. S. Dept. Agriculture, Div. Biol. Surv., Circular 47.

1905. Game Protection in 1905.- U. S. Dept. Agriculture, Yearbook, pp. 6II-6i7.

1905. Federal Game Protection. A Five Years' Retrospect.-U. S. Dept. Agriculture, Yearbook for I905, pp. 54I-562.

1905. Some Benefits the Farmers may Derive from Game Protection.- U. S. Dept. Agriculture, Yearbook for 1904, pp. 509-520.

1907. Game Protection in 1906.- U. S. Dept. Agriciulture, Yearbook for 1906, pp. 533-540.

1909. Progress of Game Protection in 1908.- U. S. Dept. Agriculture, Yearbook for I908, Appendix, pp. 580-590.

Palmer, T. S., Olds, H., Williams, R. W., Jr., and Brewster, C. E.

1900. Laws Regulating the Transportation and Sale of Game.-U. S. Dept. Agriculture, Div. Biol. Surv., Bull. I4. 
1900. Information Concerning Game; Seasons, Shipment, and Sale.-U. S. Dept. Agriculture, Div. Biol. Surv., Circular 31 .

1901. Digest of Game Laws for 1901.-U. S. Dept. Agriculture, Div. Biol. Surv., Bull. I6.

1902. Game Laws for I902.- U. S. Dept. Agriculture, Farmers' Bull. I60.

1903. Game Laws for 1903.- U. S. Dept. Agriculture, Farmers' Bull. I80.

1904. Game Laws for I904.- U. S. Dept. Agriculture, Farmers' Bull. 207.

1905. Game Laws for 1905.- U. S. Dept. Agriculture, Farmers' Bull. 230.

1906. Game Laws for I906.- U. S. Dept. Agriculture, Farmers' Bull. 265.

1907. Game Laws for I907.- U. S. Dept. Agriculture, Farmers' Bull. 308.

1908. Game Laws for 1908.- U. S. Dept. Agriculture, Farmers' Bull. 336.

1909. Game Laws for I909.- U. S. Dept. Agriculture, Farmers' Bull. 376 .

I910. Progress of Game Protection in 1909.-U. S. Dept.

Agriculture, Div. Biol. Surv., Circular 73.

I9I I. Progress of Game Protection in I9I0.-U. S. Dept. Agriculture, Div. Biol. Surv., Circular 8o.

1912. Game Laws for 1912.- U. S. Dept. Agriculture, Farmers' Bull. 510.

1912. Chronology and Index of the more important Events in American Game Protection r776-191 I. - U. S. Dept. Agriculture, Div. Biol. Survey, Bull. 4I.

\section{Pangburn, Clifford $\mathrm{H}$.}

1907. The Starling at New Haven, Conn.-Bird-Lore, ix, 5, p. 207.

I907. Horned Lark Breeding in Connecticut.-BirdLore, ix, 5, p. 2 I7.

1909. The Carolina Wren at New Haven, Conn.-Auk, xxvi, 2, p. 195 . 
1909. Unusual Dates for Some Birds at New Haven, Conn.-Auk, xxvi, 2, p. I98.

Pangburn, Clifford H. and Dwight B.

1908. List of the Birds of the New Haven Region.New Haven Bird Club, Bull. I.

Pennant, Thomas.

1785. Birds. Arctic Zoölogy, Vol. ii, Class ii.

Pilliry, Norman B.

1910. Brewster's Warbler at Waterbury.-Bird-Lore, xii, 2, p. 78.

Platt, Franklin,

1887. A List of the Birds of Meriden, Conn.-Trans. Meriden Sci. Ass., I885-6, ii, pp. 30-53.

1889. A Supplementary List of the Birds of Meriden, Conn.- Trans. Meriden Sci. Ass., I889, iii, p. 4 I.

Porter, Louis $\mathrm{H}$.

1892. Abnormal Plumage of Habia ludoviciana.-Auk, ix, 3, p. 302 .

1895. Southern Capture of Larus leucopterus.-Auk, xii, I, p. 76.

1895. Connecticut Notes.-Auk, xii, I, p. 86.

1907. The Breeding Habits of Empidonax virescens in Connecticut.-Auk, xxiv, I, p. 99.

1908. Nesting Habits of Birds at Stamford, Conn., as affected by the Cold Spring of I907.-Auk, xxv, I, pp. I6-2I.

1910. Hermit Thrush Breeding in Litchfield County, Conn.-Auk, xxvii, 4 , p. $46 \mathrm{r}$.

Prior, Charles E.

I882. Thrushes.-O and O., vii, 22, pp. I70-I7I.

1883. Rose-breasted Grosbeak Nesting in Jewett City.$O$. and 0 ., viii, 9, p. 7 I.

1884. Nest of the Mockingbird in Connecticut.- $O$. and $O .$, ix, 8, pp. 94-95.

1884. Notes from Jewett City, Conn.-O. and O., ix, 8, pp. 100-101. 
1884. The Black and White Creeper--O. and O., ix, 9, p. 109.

1884. Nest of the Mockingbird in Connecticut, and a Queer Nesting Place.-O. and O., ix, 9, p. II 5 .

Purdie, Henry A.

1873. Notes on Some of the Rarer Birds of New England.-Am. Nat., vii, I I, pp. 692-693.

1877. Notice of a Few Birds of Rare or Accidental Occurrence in New England.-Bull. Nutt. Orn. Club, ii, I, pp. 20-22.

I879. The Great Carolina Wren in Connecticut.-Bull. Nutt. Orn. Club, iv, r, p. 6r.

1897. A Record of 'Additional Specimens of the Whitethroated Warbler (Helminthophaga leucobronchialis).-Bull. Nutt. Orn. Club, iv, 3, p. 184.

Pynchon, W. H. C.

1900. Every-day Study of Birds, etc.-Bird-Lore, ii, I, pp. 19-22.

$\mathbf{R}$.

I884. Blue Jay. Brown Thrush.-Young Cölogist, i, 3, p. 37 .

Rawson, Calvin L. (Jennie May Whipple.)

I875. Baltimore Oriole.-O. and O., i, 4, pp. 28-29. r875-1876. The Season of '75.- O. and O., i, 12, p. 83, and ii, I, pp. I-2.

I876. Trochilus colubris.-O and O., ii, 2, pp. 9-IO. I876. Hawk Breeding and Mating.-O. and O., ii, 4, pp. 25-26.

1877. Wise as an Owl, or Stupid as an Owl - which? $O$. and $O$., iii, I, pp. I-2.

1878. Professional Oölogists.-Familiar Sci. and Fanciers' Journ., v, 4, p. 75.

1878. Woodcock killed by Telegraph Wires.-Familiar Sci. and Fanciers' Journ., v, 5, p. 94.

1878. The Season of '78.-Familiar Sci. and Fanciers' Journ., v, 6, p. II2.

1878. The End of the Season.-Familiar Sci. and Fanciers' Journ., v, 7, p. I34. 
1879. The Oölogist in Winter.-Familiar Sci. and Fanciers' Journ., vi, 2, pp. 23-24.

1879. Illogical or Oölogical.-Familiar Sci. and Fanciers Journ., vi, 3, pp. 39-40.

1879. Field Notes.-Familiar Sci. and Fanciers' Journ., vi, 4, p. 60.

1879. The Early-breeding Birds.-Familiar Sci. and Fanciers' Journ., vi, 5, p. 80.

1879. Hawking.-Familiar Sci. and Fanciers' Journ., vi, 6, pp. 95-96.

1879. The Waning Season.-Familiar Sci. and Fanciers' Journ., vi, 8, p. 126.

1879. The Close of the Season.-Familiar Sci. and Fanciers' Journ., vi, 9, pp. I42-143.

1879. Fugitive Notes.-Familiar Sci. and Fanciers' Journ., vi, 10, pp. 158-159.

r880. The Season of 1880 - The Oölogist.- O. and $O$., v, 8 , pp. $57-58$.

I880. November Notes - The Oölogist. - O and O., v, Io, pp. 77-78.

188x. The Season of '81.- O. and O., vi, 5, pp. 37-38.

I88I. Close of the Season.- O. and O., vi, 7, pp. 54-55.

I88r. Cooper's Hawk.-O and O., vi, I7, pp. 73-74. .

1882. Sharp-shinned Hawk-O. and O., vi, I2, pp. 89-9r.

I882. Hints to Collectors.-O. and O., vii, I5, pp. II7II8.

1882. Great Horned Owl's Nest and Eggs.-O. and O., vii, 16, p. 125 .

1882. Fresh Work in an Old Field [Eggs of Nashville Warbler].-O. and 0 ., vii, 22, p. 173.

1883. Nest with Four Chat's and Three Cowbird's Eggs. - O. and O., viii, 2, p. I5.

1883. Bluebird all the Year at Norwich.- 0 . and 0 ., viii, 2 , p. 15 .

I883. An Icy Nest.-O. and O., viii, 6, p. 48 . 1883. An April Walk.-O. and O., viii, 6, pp. 44-45. I883. Among the Buteos.- O. and O., viii, 3, pp. I7-I8. I883. The Hawks of '83.- O. and O., viii, II, p. 85 . 
1884. The Marsh Hawk and its Eggs.-O. and O., ix, I, p. $8 ; 2$, p. 16.

I884. Gastro-oölogical.- $O$. and $O$, ix, 5, pp. 57-58.

1884. Migration and Breeding Notes.-O. and $O$., ix, 6, pp. 68-69.

1885. An 1884 Hawk List.- O. and O., x, 2, pp. 24-25. 1885. Notes from Norwich, Conn.-O. and O., x, 5, p. 74 .

1885. Hawking.- -0 , and $0 ., \mathrm{x}, 6$, p. 89 .

1886. Owl versus Hawk.- O. and O., xi, 6, pp. 84-85. 1886. Pleasant! - O. and $O$., xi, 7, p. 102.

1887. City Singers.-O. and $O$., xii, 3, pp. 40-4I.

1887. Night Heron's Nest.-O. and $O$., xii, 7, pp. II2-II3.

1887. The Golden Eagle in Connecticut.-O. and O., xii, I2, p. 206.

1888. Icterus spurius - Eastern Race-Oölogist, v, 3, p. 37.

1888. The Parula Warbler - its Nest and Eggs.-O. and 0 ., xiii, I, pp. I-2.

1888. Nesting of the Barred Owl.-O. and O., xiii, 3, pp. $37-38$.

1888. In Embryo.-O. and O., xiii, 5, pp. 78-80.

1888. Afield.- $O$. and $O$., xiii, 6 , pp. 83-85.

1889. Easter Hawks' Eggs.- O. and O., xiv, 6, pp. 8I-83.

1890. A Wet Day with the Marsh Hawks.-O. and O., $\mathrm{xv}, 3$, pp. 33-34.

1891. The Birds of Long Point.-O. and O., xvi, 4, pp. 59-61.

1897. Another Golden Eagle in Connecticut.-Auk, xiv, 2, p. 215 .

1905-19I0. The Quail Trap.-Oölogist, xxii, 3, p. 39; 7, p. I04; I I, p. I70; xxiii, 6, p. 86; xxiv, 3, p. 38 ; 9, p. I 35 ; II, p. I70; I2, p. I85; xxv, 2, p. 25 ; I I, p. I67; xxvi, 2, p. 21 ; 4, p. 58 ; xxvii, I I, p. 129.

Raymond, D. W.

1891. The Green Heron.- Oölogist, viii, I, p. I3. 
Reed, Chester A.

1903. Color Key to North American Birds.

1904. North American Birds' Eggs.

1904. A Check List and Habitat Map.-Am. Ornith., iv, 8, pp. 209-227.

Rich, Walter $\mathrm{H}$.

1907. Feathered Game of the Northeast.

\section{Ridgway, Robert.}

1887. A Manual of North Ameriçan Birds.

1896. A Manual of North American Birds. Second Edition.

190I. The Birds of North and Middle America. Part i.Bull. U. S. Nat. Mus., No. 50.

1902. The Birds of North and Middle America. Part ii. - Bull. U. S. Nat. Mus., No. 50.

1904. The Birds of North and Middle America. Part iii. - Bull. U. S. Nat. Mus., No. 50.

1907. The Birds of North and Middle America. Part iv. - Bull. U. S. Nat. Mus., No. 50.

191 I. The Birds of North and Middle America. Part v. - Bull. U. S. Nat. Mus., No. 50.

See also Baird, Spencer F.

Roberts, George, Jr.

1897. Tyrant Flycatchers in New England--Oölogist, xiv, 4, pp. 39-4I.

Rogers, Ruth.

1905. Notes on Winter Feeding.-Bird-Lore, vii, 5, p. $24 \mathrm{I}$.

Royce, E. D.

I890. Two Instances of Strange Co-habitation. Wood Thrush and White-eyed Vireo.-Oölogist, vii, 8 , p. 158.

Sage, John $\mathrm{H}$.

1878. Birds of the Garden and Orchard.-The Constitution (Middletown, Conn.), xli, I5.

1878. Birds of the Garden and Orchard.-Familiar Sci. and Fanciers' Journ., v., 3, pp. 50-51. 
1879. Field Notes.-Familiar Sci. and Fanciers' Journ., vi, 4 , p. $60 ; 5$, p. 80 .

1880. King Rail at Portland, Sept. IIth, 1879.-Forest and Stream, xiv, 6.

I88I. Rose-breasted Grosbeak.-O and O., vi, I, p. 5. I88I. Birds and Windows.-Bull. Nutt. Orn. Club, vi, 3, p. 188.

188I. A Sparrow Hawk Breeding in a Barn, and Capture of Accipiter fuscus in Winter.-O. and O., vi, I, p. 6.

1882. Spring Notes.-Forest and Stream, xviii, 16, p. 305.

I882. Golden-winged Warbler [in Connecticut].-O. and O., vii, p. I4I.

I883. White Heron (Herodias alba egretta) shot at Saybrook, Conn.-O. and O., viii, I, p. 4.

I883. Snowy Owl shot at Portland, Nov. I8th.-O. and $O$., viii, I, p. 4.

I883. Black Snowbird - Junco hyemalis.-O. and O., viii, 2, p. I4.

1883. Pine Grosbeaks and Snowy Owl at Portland.-O. and $O$., viii, 3, p. 24.

1883. Lapland Longspur taken near Portland, Jan. 26, I883.- O. and $O$., viii, 6, p. 42.

I883. Capture of the Great Carolina Wren (Thryothorus ludovicianus) in Connecticut in March.-Bull. Nutt. Orn. Club, viii, 2, p. 120.

1883. Capture of the Blue-gray Gnatcatcher (Polioptila corulea) in Connecticut.-Bull. Nutt. Orn. Club, viii, 3, p. 179.

1883. A Partial Albino Short-eared Owl (Asio accipitrinus) in Connecticut.-Bull. Nutt. Orn. Club, viii, 3 , p. 183 .

I884. Another Example of Helminthophila leucobronchialis from Connecticut.-Auk, i, I, p. 9I.

I885. Return of Robins to the Same Nesting Places.Auk, ii, 3, p. 304.

1885. Helminthophila leucobronchialis from Connecticut. - Auk, ii, 3, p. 304. 
I885. Nesting of the Worm-eating Warbler in Southern Connecticut.-Auk, ii, 3, p. 305.

1886. Icterus galbula in Connecticut in November.Auk, iii, I, p. I35.

I886. A Partial Albino Hermit Thrush.-Auk, iii, 3, p. 282.

1886. Lincoln's Sparrow and the Blue-gray Gnatcatcher in Connecticut.- $A u k$, iii, 4 , p. 487.

1886. Carolina Wren in Connecticut.- $A u k$, iii, 4, p. 489. 1887. Birds about our Homes.-Middlesex Co. Record (Portland, Conn.), May 20.

I887. Middletown, Conn., Glossy Ibis of I850.- Auk, iv, 3 , p. 253.

1889. The Interbreeding of Helminthophila pinus and $H$. chrysoptera.-Auk, vi, 3, p. 279.

1889. Snowy Owl in Connecticut.-Forest and Stream, xxxiii, 2I, p. 405.

1889. A Flight of Hawks.-Abst. Linn. Soc., N. Y., i, p. 6.

1890. Some Winter Birds.-The Observer, i, I, p. 5.

I89o. Black Guillemot in Connecticut.-Auk, vii, 3, p. 283.

I89o. Diurnal Birds of Prey [found at Portland, Conn.]. - The Observer, i, 2, p. 25.

I890. Evening Grosbeaks in Connecticut.-Forest and Stream, xxxiv, 10, p. 187.

I891. Ammodramus caudacutus nelsoni and A. c. subvirgatus in Connecticut.-Auk, viii, I, p. I I 5 .

1893. Notes on some Connecticut Birds.-Auk, x, 2, pp. 206-207.

1893. Notes on Helminthophila chrysoptera, pinus, leucobronchialis, and lawrencei, in Connecticut. - Auk, x, 2, pp. 208-209.

1893. The Summer Tanager in Connecticut.-Auk, $\mathrm{x}, 3$, p. 303 .

I893. Notes on some Connecticut Birds.-Auk, x, 4, p. $37 \mathrm{I}$.

I894. Albino [Red-winged] Blackbird-Forest and Stream, xlii, 13, p. 267. 
1894. Notes on some Connecticut Birds.-Auk, xi, 2, p. 181 .

1894. Migrating Warblers [at Portland].-The Observer, $\mathrm{v}, 6$.

I895. A Swallow Roost near Portland, Conn.-Auk, xii, I, p. 83 .

1895. A Chimney Swift's Nest.-The Observer, vi, 5.

1895. A Sora Caught by a Mussel.-Auk, xii, 3, p. 297.

1895. Nesting of Helminthophila leucobronchialis in Connecticut.-Auk, xii, 3, p. 307.

1895. Notes on some Connecticut Birds.-Auk, xii, 3, p. 310.

1895. A Sora Caught by a Mussel.- The Nautilus, ix, 5 . 1895. The White-winged Scoter (Oidemia deglandi) [at Portland].- The Observer, vi, II.

1898. List of Birds found about my house at Portland, Conn

1898. Goshawks at Portland in Jan., I898.-Abst. Linn. Soc., N. Y., x, p. 5 .

1899. Fall Migration at Portland, Conn.-Bird-Lore, i, 4, p. 128.

1899. Great Migration Wave at Portland on May I8, 1898.-Abst. Linn. Soc., N. Y., xi, p. 5.

1900. Spring Migration at Portland, Conn.-Bird-Lore, ii, 2, pp. 56-57.

I900. Tennessee Warbler and Pigeon Hawks at Portland. - Abst. Linn. Soc., N. Y., xii, p. 4.

I901. February Bird Life in the Vicinity of Hartford.Hartford Times, Feb. 6.

1901. List of Birds [found about my house at Portland, with additions].- Nature Study Manual of the Public Schools of Middletown, Conn., pp. 42-45. 1902. Spring Migration. Average Dates of Arrival of Birds within Fifteen Miles of Hartford.Hartford Scientific Society.

1904. Cold Weather Visitors.-Hartford Times, Feb. 29. 1904. April Bird Life in the Vicinity of Hartford, Conn. 
1906. The Baltimore Oriole-dates of first appearance at Portland.-Penny Press (Middletown, Conn.), May 9.

1908. Purple Grackles.-Hartford Courant, March I3. 1908. Arrival of the Fox Sparrow.- Hartford Courant, March I8.

1908. Willow Island, Conn.-Bird-Lore, x, 4, pp. I89-191. I909. Pine Grosbeaks.- Hartford Courant, Jan. 20.

1909. The Black Gyrfalcon in Connecticut.-Auk, xxvi, 4, pp. 429-430.

1910. About Mockingbirds [in Hartford].-Hartford Courant, April 25.

I9I I. Dates of Arrival of the Baltimore Oriole (Icterus galbula) at Portland, for forty years.

1912. Fox Sparrows.-Penny Press (Middletown, Conn.), March 29.

1912. Starling Habits.-Forest and Stream, 1xxviii, I3, p. 407.

1912. Holbœll's Grebe in Connecticut.-Auk, xxix, 2, p. 233.

St. John, Prof. Edward P.

I9I I. Evening Grosbeaks at Hartford, Conn.-BirdLore, xiii, 2, p. 94.

I9I I. Mockingbird Wintering: in West Hartford, Conn.Bird-Lore, xiii, 2, p. 97.

Samuels, E. A.

I872. Birds of New England and Adjacent States. Sixth Edition.

Sanford, Leonard C., M. D.

I903. The Water-Fowl Family.

Saunders, A. A.

1907. Starling at New Haven, Conn.-Bird-Lore, ix, 5, p. 207.

1908. Growth of Young Black-billed Cuckoos.-BirdLore, x, 5, p. 205.

1908. List of the Birds of the New Haven Region.-Nere Haven Bird Club, Bull. I. 
I9I I. A Study of the Nesting of the Cedar Waxwing.Auk, xxviii, 3, pp. 323-329.

Schaller, Carleton.

1905. Two Weeks with the Birds in Kent, Conn.Wilson Bulletin, No. 52, xvii, 3, pp. 97-99.

Schwab, Rev. L. H.

1899. An Odd Nesting Site.-Bird-Lore, i, 5, p. 166.

Schwarz, E. A.- See Barrows, Walter B.

Scott, William E. D.

1905. On the Probable Origin of certain Birds. - Science,

N. S., xxii, pp. 271-282.

Selinger, Mrs. W.

I897. The Nest Building of the Swallows.-Oölogist, xiv, 3, p. 29.

Seton, Ernest Thompson.

1909. The Hollow Tree.-Bird-Lore, xi, I, pp. I-3.

Shailer, Laura B.

I904. Tame Hummingbirds.-Am. Ornith., iv, I, p. 3 I.

Shailer, Minnie L.

1903. From Our Mail Bag.-Am. Ornith., iii, 2, p. 78.

Shelton, G. H.

1888. Kingfishers in Winter [in Connecticut].-Forest and Stream, xxx, p. IO4.

Shufeldt, Robert W., M.D.

I886. Contribution to the Comparative Osteology of the Trochilidæ, Caprimulgidæ, and Cypselidæ.Proc. Zool. Soc. London, I885, pp. 886-9I5.

1888. Morphological Studies of the Macrochires.-Linnean Soc. Journ., London, xx, pp. 299-394.

1893. On the Mechanism of the Upper Mandible in the Scolopacidæ.-Ibis, Oct., 1893 .

Smith, Clara C.

I899. The Tragedy of a Nest.-Osprey, iii, 9, I35.

Smith, Elbert E.

1904. The New Year's Bird Census at Bristol.-Wilson Bulletin, No. 46 , xvi, I, p. 16. 
Smith, Harriet S.

1905. Notes on Winter Feeding.-Bird-Lore, vii, 5, p. 240.

Smith, Wilbur F.

1903. The Carolina Wren at South Norwalk, Conn.Bird-Lore, v, 5, p. 163.

1905. An Interesting Phøbe's Nest.-Bird-Lore, vii, 2, p. 144.

1905. Blue Jays at Home-Bird-Lore, vii, 6, p. 268. 1905. Taming a Young Cowbird.-Am. Ornith, v, 7, pp. 173 -I 74 .

1906. The Blue Jay.-Am. Ornith., vi, 1, pp. 6-8.

1906. Photographing a Red-tailed Hawk's Nest.-BirdLore, viii, 4, p. 138 .

1908. The Value of the Starling.-Bird-Lore, x, 2, p. 79. Igri. The Friendly House Wrens.-Bird-Lore, xiii, 3, pp. 135-140.

191 1. A Strange Partnership.-Bird-Lore, xiii, 6, pp. 303-304.

I9I I. Notes from Connecticut.-Bird-Lore, xiii, 6, p. 307.

1912. Prothonotary Warbler in Connecticut in November. -Bird-Lore, xiv, 2, p. Iog.

1912. Bird Notes from South Norwalk, Conn.-BirdLore, xiv, 2, p. II4.

1912. An Eagle Story.-Bird-Lore, xiv, 4, p. 228.

Stannis, J. A.

1879. Rough-winged Swallow in Connecticut.-Bull. - Nutt. Orn. Club, iv, 2, p. IIg.

Stearns, Wilfred A.

I88I. Oscines.-New England Bird Life, Part I.

1883. Non-Oscine Passeres, Birds of Prey, Game, and Water Birds.- New England Bird Life, Part II.

Stone, Witmer, D.Sc.

The Molting of Birds, with Special Reference to the Plumages of the Smaller Land Birds of Eastern 
North America.-Proc. Acad. Nat. Sci., Phil., Jan., I896, pp. I08-I67.

Studer, Jacob $\mathrm{H}$.

1903. The Birds of North America. [Young Rails (Soras) caught at Wethersfield, Conn., in June. p. 4.]

T., W. G.

1885. Interesting Happenings.-Young Oölogist, ii, I, p. 22.

Taylor, H. H.

1895. Baird's Sandpiper on Long Island Sound [Bridgeport, Conn.].-Auk, xii, 2, p. I79.

1896. The Carolina Wren in Connecticut.-Auk, xiii, I, p. 84 .

Thayer, Gerald H.

1906. A Brief General Classification of the Songs of Eastern North American Wood Warblers.Bird-Lore, viii, 2, pp. 64-65.

Thompson, Charles A.

I883. Horned Grebe in Connecticut.-O. and O., viii, I, p. 3 .

Townsend, Charles W., M. D.

1909. A Carolina Wren Invasion of New England.Auk, xxvi, 3, pp. 263-269.

Treat, Willard E.

I886. Notes on Winter Birds of East Hartford, Conn.Hoosier Naturalist, I, p. I29.

1886. White Eggs of the Blackbird.-O. and O., xi, 4, p. 53 .

1887. Capture of Three Rare Birds near Hartford.$A u k$, iv, I, p. 78 .

1887. Xanthocephalus xanthocephalus.-Auk, iv, 3, p. 256.

1887. Spizella pusilla Wintering near Hartford, Conn.Auk, iv, 3, p. 259.

I888. Helminthophila celata in Connecticut.-Auk, v, 3 , p. 323 . 
1889. A Fishing Screech Owl.-Auk, vi, 2, p. 189.

I889. Food of the Shrike.-O. and O., xiv, 5, pp. 75-76. 1890. Mortality among Bank Swallows.-Auk, vii, I, p. 96.

1891. Anas crecca in Connecticut.-Auk, viii, I, p. II2. 1892. Ereunetes occidentalis in Connecticut.-Auk, ix, 4 , p. 389 .

1893. Unusual Habits of Lincoln's Sparrow.-Auk, x, 2, p. 206.

1894. Phalaropus lobatus (a correction).-Auk, xi, I, p. 74 .

1895. Brunnich's Murre in Connecticut.-Auk, xii, 2, p. I77.

Trotter, Spencer, M. D.

1909. The Geological and Geographical Relations of the Land-Bird Fauna of Northeastern America.Auk, xxvi, 3, pp. 22 I-233.

1912. The Faunal Divisions of Eastern North America in Relation to Vegetation.-Journ. Acad. Nat. Sci., Phil., second series, xv, pp. 207-218.

Trowbridge, Prof. C. C.

1887. Something New about the Flight of Birds.- $O$. and $O$. xii, 12, p. 202.

1894. On Motion of Tips of Bill in Certain Shore-Birds. - Ibis, Sixth Series, vi, 3, pp. 449-45I.

1895. Hawk Flights in Connecticut.-Auk, xii, 3, pp. 259-270.

1897. Occurrence of Tryngites subruficollis in New England.-Auk, xiv, 2, p. 209.

1902. The Relation of Wind to Bird Migration.-Am. Nat., xxxvi, 429, pp. 735-753.

1906. On the Interlocking of Emarginate Primary Feathers in Flight.-Am. Journ. Sci., xxi, pp. I45-I69.

Trumbull, Gurdon.

1888. Names and Portraits of Birds which interest Gunners. 
1890. American Woodcock.-Forest and Stream, xxxv, 2I, p. 412.

1892. Our Scoters.-Auk, ix, 2, pp. 153-160.

1893. Our Scoters.-Auk, x, 2, pp. 165-176.

Tuttle, H. E.

19II. The Nesting of the Whip-poor-will--Bird-Lore, xiii, 5, pp. 235-238.

Van Name, Willard G.

I888. Occurrence of the Yellow-bellied Woodpecker at New Haven, Conn.-O. and O., xiii, 9, p. I35.

I901. A Connecticut Game Preserve.-Bird-Lore, iii, 3, p. II5.

Verrill, Prof. Addison E.

I865. Cliff Swallows at Windsor, Conn., in I830.- Proc. Boston Soc. Nat. Hist., ix, p. 277.

1897. Golden Eagle taken near New Haven, Conn.$A u k$, xiv, I, p. 89.

Verrill, Alpheus $\mathrm{H}$.

1888. The Philadelphia Vireo in Connecticut.-O. and O., xiii, 7, p. I03.

1893. Winter Birds in Connecticut.-Auk, x, 2, p. 207.

1893. Connecticut Notes.- Auk, x, 3, p. 305.

I893. Connecticut Notes.- $A u k, \mathrm{x}, 4, \mathrm{p} .37$ I.

Verrill, George E.

1892. Carduelis elegans in Connecticut.-Auk, ix, 3, p. 301 .

Voorhees, Clark G.

I893. Occurrence and Breeding of the Kentucky Warbler in Connecticut.-Auk, x, i, p. 86.

I894. Connecticut Notes.-Auk, xi, 3, p. 259.

W., J. M.-See Rawson, Calvin L.

Wade, Joseph $\mathbf{M}$.

I881. A Tame Wild Blue Jay.-O. and O., vi, 5, p. 36.

1883. Crow and Snake.-O. and O., viii, 2, p. II.

I883. Blue Yellow-backed Warbler's Nest.-O. and O., viii, 2, pp. I2-13. 
I883. Bobolinks (editorial).- O. and 0 ., viii, 2, p. I4. 1883. Set of Five Great Horned Owl's Eggs taken by Dr. Wood.- O. and 0 , viii, 2, p. I5.

1883. Purple Finches feeding on seeds of Tulip-poplar.0 . and 0 ., viii, 6, p. 48.

I883. Woodcock and Turtle- - O. and O., viii, 8, p. 63. 1883. Peculiar Nesting Place [Purple Martin nesting in hollow rail].- 0 . and 0 ., viii, 9, p. 67.

I883. Albino Blackbird shot at Rockville, Conn.- O. and O., viii, 9, p. 72 .

I883. Rare Finds by J. N. Clark.-O. and O., viii, Io, p. 75 .

I889. Half Albino Woodcock shot near Rockville, Conn. - O. and O., xiv, II, p. 176 .

1892. Phœbe Bird - Pewee.-O. and O., xvii, 5, pp. 77-78.

Wallace, $\mathbf{N}$.

1893. Mongolian Pheasants are good Swimmers.Forest and Stream, xl, I6, p. 338.

Walter, Alice Hall.

I9II. [Spread of the Starling in Connecticut].-BirdLore, xiii, 4, p. 220.

Watson, Amelia M.

1894. Taming a Chipping Sparrow (Spizella socialis).$A u k$, xi, 3, pp. 256-257.

Webster, Frank B.

I884. Pine Grosbeaks in Connecticut.- O. and O., ix, 3,

p. 33 .

1890. Two Snowy Owls at Groton Long Point, Conn.0 . and $0 ., \mathrm{xv}, \mathrm{I} 2, \mathrm{p} . \mathrm{I} 88$.

1891. Runt Red-winged Blackbird's Egg.-O. and $O$., xvi, I, p. 16.

1892. A Pure White Robin shot at Stafford Springs, Conn.- O. and O., xvii, 5, p. 79.

1893. Grosbeaks and Goshawk at Eastford, Conn.$O$. and 0 ., xviii, 2, p. 3 I. 
Werking, F. J.

1911. Evening Grosbeaks at Taftville, Conn.-Bird-Lore, xiii, 2, p. 94 .

Williams, R. W., Jr.-See Palmer, T. S.

Whipple, Jennie May.-See Rawson, Calvin L.

Wilson, Alexander, and Bonaparte, Charles Lucien J. L. 1832. American Ornithology.

Wilson, James.

1900. Protection and Importation of Birds under Act of Congress, approved May 25, I900. U. S. Dept. Agriculture, Div. Biol. Surv., Circular 29.

Wood, Howard L., M.D.

1901. Wedded for Life [Chimney Swift mated for five years].-Am. Ornith., i, Io, p. 194.

Wood, Dr. William.

1861. Birds of Connecticut.-Hartford Times, March 16, 23, 30, April I3, 20, 27, May 4, I I, 18, 25, June I, 8, 15, 22, 29, July 6, 20, 27, Aug. 10, 17, 24.

1868. The Mottled Owl.-Am. Nat., ii, 7, pp. 370-375. 1868. A Review of some of the Articles published in this Journal respecting the Habits and Nesting of our Birds, with additional Facts.-Am. Nat., ii, 7 , pp. $377-380$.

1869. Preparation of Birds' Eggs.-Am. Nat., iii, 2, pp. 106-107.

1869. The Red-tailed Hawk.-Am. Nat., iii, 8, pp. 393397.

1871. Migration of Hawks.-Am. Nat., iv, 12, pp. 759760.

1871. The Game Falcons of New England - the Duck Hawk. - Am. Nat., v, 2, pp. $80-87$.

1872. Instructions for Preparing Birds' Eggs.- Am. Nat., vi, 5, pp. 28I-282.

1873. The Game Falcons of New England - the Pigeon Hawk. - Am. Nat., vii, 6, pp. 340-345.

1874. The Game Falcons of New England - the Sparrow Hawk. - Am. Nat., viii, 5, pp. 266-27o. 
1876. The Game Falcons of New England-the Goshawk.-Am. Nat., x, 3, pp. I32-135.

1878. Instructions for Preparing Birds' Eggs.- $F a$ miliar Sci. and Fanciers' Journ., v, 3, pp. 5I-52. 1878. The [Rapacious] Birds of Connecticut. - Familiar Sci. and Fanciers' Journ., v., pp. 6-7, 26-28, 4950, 73-75, 93-94, I I I, I 32-I34, I 52-I 55, I 7 I-I 72, I9I-I92, 210-2I I, 226-227.

1878. “Evidences of Design in Birds' Eggs.” Reply.Familiar Sci. and Fanciers' Journ., v, 6, p. II3. 1879. The [Rapacious] Birds of Connecticut.-Familiar Sci. and Fanciers' Journ., vi., pp. 2-5, 21-22, 37$38,57-58,77-79,93-94$, 109-110, 125-126, 141142.

1879. Eleven Bald Eagles taken in Thirteen Months.Familiar Sci. and Fanciers' Journ., vi, 9, p. 143. 1880. Hooded Merganser.- O. and O., v, 12, p. 93. I88I. Red-headed Woodpecker.- $O$. and $O$., vi, Io, pp. 78-79.

1881. White or Snowy Owl--Hartford Times, Dec. 14.

1882. Hatching Hawks' Eggs [under Hens].-O and O., vii, I5, p. II8.

1883. Birds of Connecticut. The Great Horned Owl.Hartford Times, May 18.

1883. Birds of Connecticut. The Mottled Owl- - Hartford Times, Nov. 30.

1884. Short-eared Owl.-O. and O., ix, I, p. Io.

I884. Question Answered. "Hell-diver."-O. and $O$., ix, 7, p. 89 .

1885. Birds of Connecticut. The Long-eared Ow1.Hartford Times, April 20.

Woodruff, E. Seymour.

1905. Notes from Northwestern Connecticut.-Auk, xxii, 4, p. 420.

1906. A Cape May Warbler in Litchfield County, Conn. - Auk, xxiii, r, p. 105.

1906. A List of the Birds of Litchfield, Conn.- Litchfield Enquirer, 1xxxi, 3. 
1906. The Prairie Horned Lark a Summer Resident in Connecticut.-Auk, xxiii, 4 , p. 46 r.

1906. Probable Breeding of the White-throated Sparrow in Connecticut.-Auk, xxiii, 4, p. 46I.

1907. Starlings at New Haven, Conn.-Abst. Linn. Scc., N. $Y$., I8, p. 15.

1908. The Ruffed Grouse. A Study of the Causes of its Scarcity in 1907.- Ext. from 13th Ann. Rep. Frrest, Fish, and Game Commissioner, State of New York.

1908. Nesting Habits of the Henslow's Sparrow.-BirdLore, $\mathrm{x}, 3$, pp. II I-II3.

Woodruff, Lewis B.

I890. Baird's Sandpiper at New Haven, Conn.-Auk, vii, I, p. 89.

1892. Bird Notes from Litchfield, Conn--Auk, ix, 3 , p. 202.

Woolsey, George, M. D.

1880. Worm-eating Warbler Breeding in Southern Connecticut.-Bull. Nutt. Orn. Club, v, 2, p. I 16. 1880. Capture of Connecticut Warbler in Spring at New Haven.-Bull. Nutt. Orn. Club, v. 2, p. II7. (Cf. Allen, Bull. Nutt. Orn. Club, I88I, p I I4.) I880. The Ipswich Sparrow at New Haven.-Bull. Nutt. Orn. Club, v. 2, p. 121.

Wright, Mabel (Osgood).

I899. Birdcraft.

IgoI. Bird Retreats in Connecticut.-Bird-Lore, iii, 2, p. 79.

1901. The New Bird Laws.-Bird-Lore, iii, 5, p. I8o. 1905. A Year with the Birds. A Guide to the naming of roo Birds commonly found in Connecticut.Conn. School Document No. 4, 1905, pp. 145.

1908. A New Plan of the Connecticut Audubon Society. -Bird-Lore, x, 2, p. 89. 
1911. Birds and Seasons in my Garden.-Bird-Lore, xiii, I, pp. I-7; 2, pp. 67-74; 3, pp. I28-I34; 4, pp. I79-I $86 ; 5$, pp. $229-235 ; 6$, pp. $279-284$.

Zerega, Louis A.

1880. Notes on the Northern Range of the Fish Crow.Bull. Nutt. Orn. Club, v, 4, p. 205.

Anonymous.

I867. Natural History Miscellany. Zoölogy. [Introduction of English Sparrow, "Forty Pairs have just been imported into New Haven."]- $A m$. Nat., i, 4, p. 2 Ir. 



\section{PART II}

\section{Economic Ornithology}

BY

LOUIS BENNETT BISHOP 


\section{19:3 54}

yadodatmo simonoud

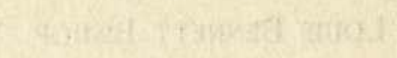




\section{Economic Ornithology.}

BIRDS are of value to the State as (I) destroyers of noxious insects, their eggs and larvæ, and also of small mammals, especially when such injurious animals appear in excessive numbers; (2) destroyers of weed seed; (3) replanters of forests; (4) food; (5) sport; (6) scavengers; (7) guides to fishermen; (8) means of mental enjoyment.

As destroyers of insects that infest the garden, orchard, field, and forest, and consumers of enormous quantities of weed seed, birds have their greatest economic value; and their feeding habits have been studied by ornithologists connected with the Department of Agriculture of the National Government and by others in similar positions in various states. Brief extracts from the results of these investigations will be found in the following pages. Suffice it here to say that only one Owl, a few Hawks, Crows, some Blackbirds, the Starling, and the English Sparrow seem undeserving of protection. But that an abundance of birds is of great benefit on the farm the following extract from "Useful Birds and their Protection" by E. H. Forbush, State Ornithologist of Massachusetts, will show: and this valuable work can be cordially recommended to all those who wish to study this subject further than is possible for us in this Bulletin. "My first attempt at availing myself of the services of the birds in an orchard was made in 1894-95, and the result was given in a bulletin issued by the State Board of Agriculture. In the winter birds were attracted to the orchard, and frequented the trees during the entire winter of 1894-95. In the fall, winter, and spring they destroyed thousands of the imagoes and eggs of the fall and spring cankerworm moths, the eggs of the tent caterpillar, and probably also the pupæ and imagoes of the codling moth, besides scales, tineids, and other enemies of the trees. When spring came, efforts were made to attract the summer birds to the orchard. These attempts met with 
such signal success that, although most of the eggs and young birds were destroyed by cats, boys, crows, and other agencies, the remaining injurious insects were so completely disposed of by the birds that the trees bore luxuriant foliage during the entire summer, and produced a good crop of fruit. This occurred in a season when the tent caterpillar and the cankerworm were remarkably prevalent. The only other orchard in the neighborhood that produced any fruit whatever was that of the nearest neighbor. This had been partly protected by tarred bands and partly by the birds from my place. Elsewhere in the town most of the apple trees were defoliated, and very few produced any fruit that year. While the result secured in such an exceptional year seemed remarkable, the experience of succeeding years has demonstrated that it was not so. Year after year we have kept the trees free from insect injury, without spraying or otherwise protecting the foliage, merely by a little effort and expenditure to attract the birds and furnish them safe homes. While the protection of the tree itself is essential (i. e., its trunk, limbs, twigs, and bark), the protection of its foliage, which shades the fruit and so allows it to mature, is also imperative."

As regulators of occasional outbreaks of noxious animals birds have played a valuable part more than once in the past. In the invasions of locusts that occur occasionally in the West, birds of all sorts - hawks, owls, geese, ducks, grouse, pigeons, shore birds, woodpeckers, gulls, crows, blackbirds, herons, vireos, sparrows, swallows, warblers, thrushes, and even hummingbirds - swarm to the feast and devour these insects in incredible numbers. The same thing is true when the hordes of the army-worm appear. In the plagues of mice that sometimes infest parts of Europe, hawks and owls flock to the spot, and feed on little else until these animals are reduced to their normal numbers. If we wantonly destroy our hawks and owls, we lay ourselves open to such outbreaks, and have removed those whose pleasure it would be to protect us in such an emergency.

The value of certain species as a source of food, and from the standpoint of sportsmen, is too well understood to require discussion. Formerly, when Roseate Terns (Sterna dougalli) 
were abundant in the Sound, fishermen could frequently ascertain the presence of bluefish by watching the actions of these birds, as they caught the smaller fish driven to the surface by the large ones; and any one who has watched the Herring Gulls (Larus argentatus) swarming at the mouths of the sewers of cities, will realize their value as scavengers. How far birds help in replanting forests is questionable, but there is no doubt that Jays and Pigeons do assist somewhat by transporting acorns and the seeds of other trees.

To provide mental enjoyment may not seem at first sight a part of the function of the State, but there is a large and steadily increasing body of people, valuable citizens, who derive great enjoyment from listening to the songs and studying the habits of birds, who will go where birds are and keep away where birds are not. Surely it is more to the advantage of the state to protect birds and encourage these people to live with us than it is to allow our smaller birds to be shot for the morsel of meat their bodies may afford. From this standpoint alone, the protection of birds is certainly a good investment for the state.

Those also who are interested in birds from a scientific standpoint must not be forgotten, as from their ranks have come most of the men whose investigations of the feeding habits of birds are quoted in the following pages. As almost all ornithologists begin their study of birds by collecting skins and eggs in boyhood - the training of the eye and ear in youth being apparently essential for success in field ornithology,- no laws making permits unreasonably difficult to obtain should be passed. Since under normal conditions at least twice as many birds die each year as are living at the beginning of the year, legitimate collecting can have but little effect on their numbers; and this the killing of a few vagrant cats would offset many times over.

\section{GREBES, LOONS, and AUKS.}

Colymbide, Gaviida, and Alcida.

Of the five species of Grebes and Loons occurring more or less frequently in Connecticut, only two breed with us, and those but rarely. Their habits are entirely aquatic except in the breeding season, and even then the Grebes build floating 
nests of decaying vegetation in lakes or ponds. Their food habits are such that they are of little economic importance. The food of the Loons is almost entirely small fish, while the Grebes vary this diet with aquatic insects, tadpoles, lizards, grass, locusts, and grasshoppers.

The Auks are found only as stragglers in our waters, and the small fish and crustaceans they consume are of no value.

\section{JAEGERS and MAN-O'-WAR BIRDS.}

\section{Stercorariide and Fregatide.}

Wanderers on our shores, the Jaegers find the terns on which they largely depend for food so rare that they do not stay long with us. Their ordinary method of procuring food is to chase a tern or small gull until the latter drops the fish it has in its bill or disgorges what it has swallowed. This the robber seizes before it reaches the water; then searches for a fresh victim. When forced to forage for themselves, they live on fish, frogs, crawfish, and even grasshoppers.

The Man-o'-War Bird (Fregata aquila) has the habits of the Jaegers, but is only accidental in our state.

\section{GULLS and TERNS.}

\section{Laride.}

All is flesh that a Gull can find to eat as long as it is not vegetable. Their usual food with us is fish, but the manner the Herring Gulls (Larus argentatus) collect at the mouths of the sewers of cities shows that other matter is not objectionable. They are the scavengers of the waters, feeding on all animal matter they can find, whether alive or dead. "Other times other manners"; the head of a Ptarmigan was found in the throat of a Glaucous Gull (Larus hyperboreus) shot by the author in Alaska, and Mr. E. T. Judd took a Yellow Warbler from the stomach of a Ring-billed Gull (Larus delawarensis) in North Dakota. In that state and in many parts of the West flocks of Franklin's Gulls (Larus franklini) following the plow, and alighting on the freshly turned sod in search of worms and grubs, are a common sight. Grasshoppers and locusts are also a welcome addition to the food of many 
species; mollusks, mammals, young birds, and eggs are freely taken when occasion offers, as is the most putrid carrion. Thus acting as scavengers, the good they do greatly outweighs any harm their killing the few birds can be, and, with their beauty, should cause them to receive all possible protection.

Devoted almost exclusively to a diet of small fish, the few Terns (Sterna hirundo) that now breed on our shores, are objects of beauty to those who are fortunate enough to see them. Formerly, fishermen found their presence in numbers an indication that large fish had driven the smaller to the surface, and considered them useful accordingly. The Least Tern (Sterna antillarum) feeds largely on grasshoppers, spiders, and aquatic insects, while one who has watched the Black Terns (Hydrochelidon nigra surinamensis) skimming over the ponds of the West after the manner of swallows, can have little doubt as to the chief source of their food. Both these birds are unfortunately too rare with us to influence our insects.

The Skimmers (Rhynchopidce), Fulmars and Petrels (Procellariide), Gannets (Sulide), Cormorants (Phalacrocoracide), and Pelicans (Pelecanide), may be omitted from our study of feeding habits, as, although all feed on fish, they are very rare in Connecticut.

DUCKS, GEESE, and SWANS.

Anatidc.

These birds are chiefly important from their food value and as objects of sport, as few of them are with us when they can find locusts, beetles, or grasshoppers, on which they frequently feed in summer. Many of them eat fish, crustaceans, and shellfish, and others various grasses and water plants. Their food has no market value in our state, but in parts of the West they do great damage in the wheat fields.

HERONS, EGRETS, and BITTERNS.

Ardeidce.

The chief value of these birds is their grace and beauty, and the charm they add to the landscape; their economic importance 
is not great either for help or harm. They feed on small fish, frogs, occasionally a mouse, tadpoles, worms, grasshoppers, dragon-flies, and various insects. It is conceivable that at a fishhatchery a Great Blue Heron (Ardea herodias) might be out of place, but in the rest of the state its presence is a distinct gain.

\section{RAILS, GALLINULES, and COOTS.}

\section{Rallida.}

The Rails have their main value from an economic standpoint as ornaments to the dinner table; the diet of wild rice on which the Sora (Porzana carolina) feeds showing why its flesh stands so much higher in the opinion of epicures than that of the Clapper and Virginia Rails (Rallus crepitans crepitans and virginianus) which "feed chiefly upon grasshoppers, snails, slugs, crabs, and aquatic insects" (Weed and Dearborn, "Birds in their Relation to Man").

The Coot (Fulica americana), which is sometimes tolerably common in fall, feeds upon the same food as the last mentioned Rails, and its flesh is not highly praised.

\section{SHORE BIRDS.}

Limicolce.

The Phalaropes (Phalaropodida), Avocets and Stilts (Recurvirostrida), Woodcocks, Snipes, and Sandpipers (Scolopacide), Plovers (Charadriide), and Turnstones (Aphrizide) were supposed to have their chief economic value as being "good to eat," and in addition furnishing sport and outdoor exercise for sportsmen. But this is by no means true. They are all insect-eaters, and no doubt destroy large numbers during the months they are with us. The Woodcock and Snipe feed on worms, grasshoppers, and other insects. Of the Wilson's Snipe (Gallinago delicata) - " eight out of the eleven stomachs opened by Professor Aughey contained from 38 to 60 locusts each, besides other insects" (Weed and Dearborn, "Birds in their Relation to Man," p. 23I). The smaller Sandpipers, feeding about the pools of the salt marshes, probably have some effect on the hordes of mosquitoes by devouring their larvæ. Of the usefulness of some species in the West - most of them, alas! 
now too rare with us to be of economic importance - Professor Bruner writes: "The Snipes, Sandpipers, Plovers, Phalaropes, Curlews, etc., are great destroyers of insects. Moving, as many of them do, in great flocks, and spreading out over the meadows, pastures, and hillsides, as well as among the cultivated fields, they do a large amount of careful police service in arresting the culprits among insects. They even pry them out of burrows and crevices in the earth, where these creatures lurk during daytime only to come forth after nightfall to destroy vegetation. The large flocks of Eskimo Curlews that formerly passed through eastern Nebraska, did magnificent work during years when the Rocky Mountain locust was with us, as did also the equally large flocks of Golden Plovers. The Bartramian Sandpiper even now is a great factor each summer in checking the increasing locusts on our prairies." (Proceedings of the Nebraska Ornithologists' Union at its Second Annual Meeting.)

In "Our Vanishing Shore Birds," Mr. W. L. McAtee, of the Biological Survey, says: "Few groups of birds more thoroughly deserve protection from an economic standpoint. Shore Birds perform an important service by their inroads upon mosquitoes, some of which play so conspicuous a part in the dissemination of diseases. Thus, nine species are known to feed upon mosquitoes, and hundreds of larvæ or 'wigglers' were found in several stomachs. Fifty-three per cent of the food of twentyeight Northern Phalaropes in one locality consisted of mosquito larvæ. The insects eaten include the salt-marsh mosquito."

"Cattle and other live stock also are seriously molested by mosquitoes as well as by another set of pests, the horseflies. Adults and larvæ of these flies have been found in the stomachs of the Dowitcher, the Pectoral Sandpiper, the Hudsonian Godwit, and the Killdeer. Two species of shore birds, the Killdeer and Upland Plover, still further befriend cattle by devouring the North American fever tick."

"Crane-fly larvæ are frequently seriously destructive locally in grass lands and wheat fields. Among their numerous bird enemies shore birds rank high."

Of grasshoppers shore birds are very fond, and twenty-four species are known to feed on them. 
"Shore birds are fond of other insect pests of forage and grain crops, including the army-worm, which is known to be eaten by the Killdeer and Spotted Sandpiper; also cut-worms, among whose enemies are the Avocet, Woodcock, Pectoral and Baird Sandpipers, Upland Plover and Killdeer.

"The principal farm crops have many destructive beetle enemies also, and some of these are eagerly eaten by shore birds. Bill-bugs, which often do considerable damage to corn, seem to be the favorite food of some of the shore birds."

"The economic record of the shore birds deserves nothing but praise. These birds injure no crop, but on the contrary feed upon many of the worst enemies of agriculture. It is worth recalling that their diet includes such pests as the Rocky Mountain locust and other injurious grasshoppers, the army-worm, cutworms, cabbage worms, cotton worm, cotton cutworm, boll weevil, clover-leaf weevil, clover-root curculio, rice weevil, corn bill-bugs, wire-worms, corn-leaf beetles, cucumber beetles, white grubs, and such foes of stock as the Texas fever tick, horseflies, and mosquitoes: Their warfare on crayfishes must not be overlooked, nor must we forget the more personal debt of gratitude we owe them for preying upon mosquitoes. They are the most important bird enemies of these pests known to us.

"Shore birds have been hunted until only a remnant of their once vast numbers is left. Their limited powers of reproduction, coupled with the natural vicissitudes of the breeding period, make their increase slow, and peculiarly expose them to the danger of extermination. They should be protected, first, to save them from the danger of extermination, and, second, because of their economic importance. So great, indeed, is their economic value, that their retention on the game list and their destruction by sportsmen is a serious loss to agriculture."

\section{GROUSE, PARTRIDGES, and QUAILS.}

\section{Tetraonide and Odontophorida.}

Of the usefulness of the Bob-white or Quail (Colinus virginianus virginianus) from the sportsman's standpoint it is unnecessary to speak, but that its importance to agriculture is even greater Dr. Sylvester D. Judd has abundantly shown in the Year Book of the Department of Agriculture for 1903 ("The Economic 
Value of the Bob-white"). Dr. Judd finds that "the Bob-white is probably the most useful abundant species on the farm. It is one of the most nearly omnivorous birds, consuming large quantities of weed seeds, and destroying many of the worst insect pests with which the farmer has to contend. It does not injure grain, fruit, or any other crop.

"In the investigation 8 or stomachs were examined, collected in every month of the year, though mostly during the hunting season, and obtained from twenty-one different states.

As indicated by this material, the Bob-white is notable for the great variety of its food. It lives mainly on seeds, fruits, leaves, buds, insects, and spiders, though myriapods, crustaceans, mollusks, and even batrachians have been found in its stomach. The character of the diet varies with the season. The greatest proportion of animal matter is taken in late spring and early summer. The food for the year, as a whole, estimated from the analysis of the contents of stomachs and calculated by volume, is divided thus: animal matter, 14.93 per cent; vegetable matter, 85.07 per cent. The elements of the animal food are distributed as follows: beetles, 6.38 per cent of the total food; grasshoppers, 2.56 per cent; bugs, 2.83 per cent; caterpillars, 0.87 per cent; miscellaneous insects, 0.48 per cent; the other invertebrates. largely spiders, I.8I per cent. The vegetable food consists of grain, 23.64 per cent of the total food; various seeds, chiefly those of weeds, 50.78 per cent ; fruit, 8.53 per cent ; miscellaneous vegetable matter, 2.12 per cent.

"The Bob-white is pre-eminently a seed eater. Of its food for the year, as a whole, seeds form 50.78 per cent, and include those of many different plants.

"The bulk of this seed diet consists of the seeds of weeds. Fully sixty different weeds are represented in the food, and constitute more than a third of the food for the year as a whole. Some idea of the value of the bird as a weed destroyer may be gained from the number of seeds taken at a meal. Thirty buttonweed seeds, $200^{\circ}$ to 300 smartweed seeds, often 500 seeds of sheep sorrel, and 700 of three-seeded mercury have been taken at one feeding. Crops and stomachs are frequently crammed with nothing but ragweed. One bird, taken at Marshall Hall, Md., November 6, I902, had eaten a thousand 
ragweed akenes; another, killed the previous November in the same place, had eaten an equal number of the seeds of crabgrass, a troublesome weed in truck land. Birds have been shot in Mecklenburg . County, Va., whose stomachs contained 3,000 leguminous seeds, mostly of tick trefoil and various species of bush clover. Pigeon grass, which is extremely common and mischievous in truck land, is a favorite food. No less than 5,000 seeds of this troublesome plant were found in the stomach of a bird shot in October, 1902, at Pinebrook, N. J. Finally, a Bobwhite taken on Christmas Day, rgor, at Kinsale, Va., was discovered to have eaten Io,000 seeds of that abundant and obnoxious pest of the garden, the pigweed.

"A careful computation of the total amount of weed seed the Bob-white is capable of destroying is surprising in the magnitude of its result. In the state of Virginia it is safe to assume that from September I to 30 , the season when the largest proportion of weed seed is consumed by birds, there are four Bob-whites to the square mile, or 169,800 in the entire state. The crop of each of these birds will hold half an ounce of seed; and, as at each of the two daily meals weed seed constitutes at least half the contents of the crop, or a quarter of an ounce, a half-ounce daily is certainly consumed by each bird. On this very conservative basis the total consumption of weed seed by Bob-whites from September I to April 30 in Virginia amounts to 573 tons.

"The Bob-white is insectivorous as well as granivorous. Insects are eaten during every month of the year, and amount to I4.93 per cent of the food for the year as a whole. From May to August, inclusive, when insects are most numerous, the percentage for the period rises to $3 \mathrm{I} .5$ per cent. The variety of insect food is large. In the present investigation II6 species of insects have been noted as entering into the diet, a number that will probably be greatly augmented by further knowledge. Furthermore, the proportion of injurious insects habitually eaten by the Bob-white makes its service as a destroyer of insects more valuable than those of many birds whose percentage of insect food, though greater, includes a smaller proportion of injurious species. Conspicuous among the pests which the Bob-white destroys are the potato beetle, the 12-spotted cucumber beetle, the bean leaf-beetle, the squash ladybird, wireworms and their 
beetles, May-beetles, such weevils as the corn billbug, the imbricated snout-beetle, the clover leaf weevil, and the Mexican cotton boll-weevil, the striped garden caterpillar, the army-worm, the cotton worm, the boll worm, various species of cutworms, the corn-louse ant, the red-legged grasshopper, the Rocky Mountain locust, and the chinch bug. Some of these pests are relished, for a dozen army-worms or cutworms are frequently eaten at a meal. Thirty Rocky Mountain locusts have been found in a single crop. Weevils are greatly sought after, 47 cotton boll-weevils having been eaten in a morning by one Bob-white. Striped cucumber beetles are destroyed by the score, potato beetles by the hundred, and chinch bugs by the tablespoonful."

Dr. Judd finds that the grain forms only one-fourth of the food, corn and wheat being preferred (corn, I9 per cent; wheat, 3 per cent) ; but that this was almost entirely obtained by gleaning among the stubble, not a single sprouting kernel having been found among the crops and stomachs examined.

Although $8 \mathrm{r} / 2$ per cent of the food consists of fruit, this is largely taken during December, and consists chiefly of sumac berries. Leaves and buds are only a small portion of its food, and these are principally of yellow sorrel, sheep sorrel, and red and white clover.

From its life in the woods the Ruffed Grouse or Partridge (Bonasa umbellus umbellus) is not of as direct economic importance as the Quail. Dr. A. K. Fisher of the Biological Survey finds (Weed and Dearborn, "Birds in their Relation to Man," pp. 224-6), that they are "very fond of grasshoppers and crickets," caterpillars also often entering into their diet. "Beechnuts, chestnuts, and acorns of the chestnut and white oaks are also common articles of food. Among berries, early in the season, the blackberries, blueberries, raspberries, and elderberries are eaten with relish, while, later in the year, wintergreen, partridgeberry, with their foliage, sumach-berries (including those of the poisonous species), cranberries, black alder, dogwood, nannyberries, and wild grapes form their chief diet. In the fall the foliage of plants often forms a large part of their food, that of clover, strawberry, buttercup, wintergreen, and partridge-berry predominating. In the winter these birds feed on the buds of trees, preferring those of the apple tree, ironwood, black and white birch, and poplar. 
"In isolated cases Ruffed Grouse cause some damage to fruit trees by eating the buds in winter. The extent of the injury which a grouse is capable of doing in a season may be estimated from the contents of a crop examined by us. It was taken from a female shot in January, and contained three hundred and fortyseven apple-tree buds, eighty-eight maple buds, and twelve leaves of sheep laurel. This was, of course, a single meal; and, as two such meals are eaten per day, it must be reckoned as half the daily consumption.

"One of the crops of four birds killed during the latter part of September and subjected to the same scrutiny showed barberries five per cent, sumac seeds twenty per cent, and apple pulp twenty per cent. Another contained ten per cent of mushrooms and ninety per cent of red-humped oak caterpillars (Edema albifrons). The other two were shot from the same flock at the same time. Their crops were packed with the oak caterpillars above mentioned and white-oak acorns, the ratios being sixty per cent and seventy-seven per cent of caterpillars, against forty per cent and twenty-three per cent of acorns, respectively." (Weed and Dearborn.)

This habit of eating the buds of trees probably does little harm, and is more than offset by the diet of the young in the spring, which appears to be almost wholly insectivorous, judging from the few published records.

\section{PIGEONS.}

\section{Columbida.}

The Passenger Pigeon (Ectopistes migratorius) is so near extinction that we need only regret its loss without discussing its economic value.

The Mourning Dove (Zenaidura macroura carolinensis), however, though not abundant with us, is of such great value as a weed destroyer that a quotation from Dr. Judd's paper on "Birds as Weed Destroyers," in the Year Book of the Department of Agriculture for 1898 , will not be out of place in this report as evidence that our turtle dove's chief usefulness is not as game.

"It is pre-eminently a seed eater, and, although at times turning its attention to grain, it nevertheless consumes an enormous 
amount of weed seed. The crop of one dove secured in a rye field in Warner, Tennessee, contained 7,500 seeds of Oxalis stricta. Just outside the District of Columbia the bird has been seen feeding in fields overgrown with pigeon grass and ragweed, and especially in old cornfields, where smartweed and bindweed formed tangles of sufficient extent to injure the crop. In the Eastern States it has a peculiar habit of picking up pokeweed seeds and crushing them in its muscular stomach. Several weeds belonging to the genera Lithospermum, Oxalis, and Euphorbia are also utilized as food to a somewhat lesser extent. In California the dove feeds upon the seeds of a leguminous weed, known as turkey mullein (Eremocarpus setigerus). The habit is so well known in some localities that a botanist upon inquiring how he could collect some seeds of this plant was advised to shoot a few doves and open their crops."

\section{FALCONS, HAWKS, and EAGLES.}

\section{Falconida, Buteonida, and Pandionida.}

As regard usefulness our Hawks may be roughly grouped in two classes: the sailing, rather slow-flying hawks, which are beneficial; and the darting, swift-flying hawks, which are injurious. ${ }^{1}$ This of course is not invariably true, but it is true in the main, and perhaps may save some Buteo or Marsh Hawk, who pays rent for its nest in the woods or meadow by incessant warfare on mice, from paying the penalty for the attacks of the Sharpshinned and Cooper's Hawks on the poultry yard. Sportsmen have always held all forms of hawks evil and acted accordingly, shooting them indiscriminately, forgetting that the few birds some of them may take from the coveys of quail or partridge may be more than balanced by the usefulness of others; while the farmers, remembering lost chickens, are loth to believe that only two species of our common hawks are given to raids on domestic fowls, the others only seeking them when pressed for food. For the evil done by a few species, the Hawks and the Owls have been held up as enemies whose destruction should bring reward, and laws to this effect have been passed in different states. But after these laws have remained on the statute books for varying

1The Sparrow Hawk (Falco sparverius sparverius) must be excepted in the condemnation passed upon species related to it. 
periods, with no advantage except to the few who make a business of collecting bounties - one county in Pennsylvania having paid out in a year over $\$ 5,000$ in this manner,- they are usually repealed; and now many states protect all but a few of these birds. A very exhaustive study of the food of the Hawks and Owls of the United States was made some years ago by the Department of Agriculture, and.the results given to the public in a special bulletin by Dr. A. K. Fisher under the title, "The Hawks and Owls of the United States in their Relation to Agriculture." This valuable work is now out of print, but some of its more important features relative to our Hawks and Owls are here given, together with a few personal investigations on this subject.

Dr. C. H. Merriam, Chief of the Biological Survey, in transmitting this work to the Secretary of Agriculture, states that in its preparation the contents of about 2,700 stomachs of these birds were examined.

"The result proves that a class of birds commonly looked upon as enemies to the farmer, and indiscriminately destroyed whenever occasion offers, really rank among his best friends, and with few exceptions should be preserved, and encouraged to take up their abode in the neighborhood of his home. Only six of the seventy-three species and subspecies of hawks and owls of the United States are injurious. Of these, three are so extremely rare they need hardly be considered, and another (the Fish Hawk) is only indirectly injurious, leaving but two (the Sharpshinned and Cooper's Hawks) that really need be taken into account as enemies to agriculture. Omitting the six species that feed largely on poultry and game, 2,212 stomachs were examined, of which 56 per cent contained mice and other small mammals, 27 per cent insects, and only $3^{1} / 2$ per cent poultry or game birds. In view of these facts the folly of offering bounties for the destruction of hawks and owls, as has been done by several states, becomes apparent, and the importance of an accurate knowledge of the economic status of our common birds and mammals is overwhelmingly demonstrated."

Of our hawks there are only five that feed habitually. on birds; and, of these two, the Duck Hawk (Falco peregrinus anatum) and Goshawk (Astur atricapillus atricapillus) are so rare that they may be left out of consideration. 
The Sharp-shinned Hawk (Accipiter velox), though diminutive in size, is large in courage, and is the true "Chicken Hawk," and probably feeds entirely on birds when obtainable. "When a pair of Sharp-shinned Hawks find a farm where young chickens are easily obtained, they generally visit it until the supply gives out, or they themselves meet a tragic death. Nuttall speaks of a single bird which came every day to a farmhouse until it had carried away between twenty and thirty young chickens." (Fisher, "Hawks and Owls of the United States in their Relation to Agriculture.”)

Its only redeeming trait is that it kills English Sparrows as well as other birds.

Of I 59 stomachs reported by Dr. Fisher, 6 contained poultry or game birds; 99 , other birds; 6 , mice; 5 , insects; and 52 were empty. Of two stomachs examined by Mr. G. V. Smith in Connecticut, one contained a sparrow, and the other a grasshopper. Of 2 I examined by the author, I2 were empty; and the other 9 all contained birds, among which were recognized one Flicker, one Goldfinch, sparrows, and warblers.

Similar in plumage and habits to the Sharp-shinned, but slightly larger, Cooper's Hawk (Accipiter cooperi) is also to be condemned. This is the true "Hen Hawk," its food consisting largely of poultry, domestic pigeons, and game; and for its misdeeds many a hapless buzzard-hawk has been killed.

Of 133 stomachs reported by Dr. Fisher, 34 contained poultry or game birds; 52 , other birds; II, mammals; I, a frog; 3, lizards; and 29 were empty. Dr. Coues says, "it attacks and destroys hares, grouse, teal, and even the young of larger ducks" ("Birds of the Northwest," p. 338). Dr. B. H. Warren writes: "Of the thirty-four birds which I have examined, sixteen showed the food taken to have been chickens; ten revealed small birds - sparrows, warblers, and meadowlarks ; two, quail ; one, bull-frog; three, mice and insects; two, hair and other remains of small quadrupeds" ("Birds of Pennsylvania," I888, p. 8o). Three stomachs examined by the author were all empty, but one bird was shot while killing a chicken.

The Pigeon Hawk (Falco columbarius, columbarius) must also be classed among the injurious species, its food consisting chiefly of birds; but it occurs with us only as a. by no means common spring and fall migrant. 
Of 56 stomachs reported by Dr. Fisher, 2 contained poultry; 4I, small birds; 2, mice; 16 , insects; and 5 were empty. Pigeons and flickers, robins, and the various blackbirds are favorites in the Pigeon Hawk's dietary, and it has been known to kill a ptarmigan and a domestic hen. Three stomachs examined by the author contained birds.

The only other Hawk not distinctly beneficial is the Osprey or Fish Hawk (Pandion haliaëtus carolinensis). Its food consists wholly of fish; but, as the latter are not generally species used by us for food, it cannot be considered harmful.

The Marsh Hawk (Circus hudsonius), distinguished by its white rump, spends its time beating back and forth over the meadows after field mice, although it may have recourse to small birds or chickens when driven by hunger. A nest containing four young and one hatching egg, was found by the author on June 12,1900 , in a meadow at Warren not far from a farmhouse where there were many young chickens. These chickens were not dis-

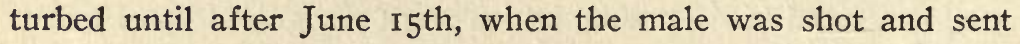
to the author. Its stomach contained a mouse. Three days later came the female and one of the young with the statement that, as soon as the male was killed, the female began to prey on the chickens. The proofs of this were the remains of a young chicken and the shell of a robin's egg in the stomach of the female, while that of the young bird contained a mouse.

Of 124 stomachs reported by Dr. Fisher, 7 contained poultry or game birds; 34 , other birds; 57 , mice ; 22 , other mammals ; 7 , reptiles; 2 , frogs; $\mathrm{I} 4$, insects; $\mathrm{I}$, indeterminate matter; and 8 were empty. Mr. E. T. Judd found three birds in the stomach of one shot in North Dakota, and Mr. G. V. Smith found birds in two he shot near New Haven. Of II stomachs examined by the author, 4 were empty; 5 contained mammals; 3 , birds; I, a snake; and I, a robin's egg.

Our Buzzard-hawks - Red-tailed, Red-shouldered, and Broad-winged (Buteo borealis borealis, lineatus lineatus, and platypterus) are the birds we see sailing in wide circles high over head. They are rather sluggish in temperament, seldom catch birds and still more rarely poultry, and are among the most useful allies the agriculturist possesses in his contest with field mice and other injurious small mammals. The Broad-winged Hawk also 
devours numbers of the large caterpillars so destructive to forests and shade trees. The Red-tailed and Red-shouldered Hawks stay with us all the year, breeding in tall trees; the former, on the hills of the interior, the latter, in the marshy woodlands near the coast; but the Broad-winged is common only for a limited time in the fall.

Of 562 stomachs of the Red-tailed Hawk reported by Dr. Fisher, 54 contained poultry or game birds ; $5 \mathrm{I}$, other birds; 278 , mice; I3I, other mammals; 37 , batrachians or reptiles; 47 , insects ; 8 , crawfish; I, centipeds; I3, offal; and 89 were empty. From this study Dr. Fisher has found that at least 85 per cent of the food of this hawk is composed of injurious rodents; which certainly shows it deserves protection. Of 173 stomachs examined by Dr. Warren, 128 contained mice, and once he found 7 mice in one stomach ("Birds of Penn.," I888, p. 86). Mr. C. L. Rawson has reported finding near Norwich in one nest of this hawk the remains of 9 red squirrels, and of 7 in another (Ornithologist and Oölogist, Vol. 8, I883, p. I7). Of five stomachs examined by the author, one was empty, and four contained mammals, chiefly squirrels.

Regarding the Red-shouldered Hawk, our most common breeding species near the coast, Dr. Fisher writes, "It is extremely improbable that this slow-flying Hawk often captures birds, except such as are disabled," and quotes a letter from $\mathrm{Mr}$. J. Alden Loring, of Owego, Tioga County, New York: "The pair reared their young for two years in a small swampy piece of woods about 50 rods from a poultry farm which contained 800 young chickens and 400 ducks, and the keeper told me he had never seen hawks attempt to catch one." Dr. Fisher reports that, of 220 stomachs examined, 3 contained poultry; 12 , other birds ; I02, mice; 40, other mammals ; 20 , reptiles ; 39 , batrachians ; 92 , insects; 16 , spiders ; 7 , crawfish ; 1 , earthworms ; 2 , offal ; 3 , fish ; and 14 were empty. Dr. Warren found field mice in 43 of 57 stomachs examined. Of 9 stomachs examined by the author, 5 were empty; 3 contained mammals ; 1 , a snake; and 2 , insects.

About the Broad-winged Hawk, Dr. Fisher reports that, of 65 stomachs examined, 2 contained small birds; I5, mice; I3, other mammals ; I I, reptiles; 13 , batrachians ; 30, insects ; 2 , earthworms ; 4 , crawfish; and 7 were empty. Of 12 stomachs examined 
by Dr. Warren, 4 contained mice; 3 , small birds; 4 , frogs; 1 , crawfish and traces of coleopterous insects. Of 6 stomachs examined by the author, 2 contained mammals; and all 6 , insects, among which were cicadas, katydids, grasshoppers, beetles, and various large caterpillars.

The Rough-legged Hawk (Archibuteo lagopus sanctijohannis) occurs with us only as a rather rare winter resident, but is altogether useful in its feeding habits. All of eleven stomachs examined by Dr. Warren contained field mice; while, of 49 stomachs reported by Dr. Fisher, 40 contained mice; 5 , other mammals; I, lizards; I, insects; and 4 were empty.

The Golden Eagle (Aquila chrysaëtos) is only a straggler with us; and the Bald Eagle (Halicetus leucocephalus) is so rare that its food is of little importance. It feeds largely on fish, carrion, small mammals, and occasionally waterfowl.

The little Sparrow Hawk (Falco sparverius sparverius), chiefly distinguishable from the Sharp-shinned by its long and pointed wings and its habit of hovering in the air, is one of our most useful birds, as its food is principally grasshoppers. Of 320 stomachs reported by Dr. Fisher, I contained a game-bird; 53 , other birds; 89 , mice; 12 , other mammals; 12 , reptiles or batrachians; 2 I 5 , insects; 29 , spiders; and 29 were empty. Of 65 stomachs examined by Dr. Warren, 31 contained field mice; 23, grasshoppers and beetles; 7, small birds; 2, meadowlarks; $\mathrm{I}$, a mouse and small birds; and $\mathrm{I}$, insects and small birds. Of Io stomachs examined by the author, 2 were empty; 3 contained mammals, chiefly mice; and 5 , insects, largely grasshoppers.

\section{OWLS.}

\section{Strigida.}

Of the six Owls occurring regularly in Connecticut, the habits of only one - the Great Horned Owl (Bubo virginianus virginianus) - are such as to deserve ostracism. Its strength, ferocity, and courage are great, and it has well been called the tiger of the air. One who has seen the fury gleaming from the eyes of a pair of these birds when he is at their nest has had an experience he will not soon forget. Both mammals and birds are its prey, and large ones at that; rabbits, squirrels, and skunks 
among the former, and quail, ducks, partridges, and domestic fowls among the latter, are the chief sufferers. Large hawks, crows, and other owls also are often killed and eaten. Dr. Merriam states: "It feeds on the larger game (hares, grouse, and the like), not forgetting the poultry yard, and seems particularly fond of turkeys, of which it seldom touches more than the head, if there are a plenty about. Indeed, I have known one to kill and decapitate three turkeys and several hens in a single night, leaving the bodies uninjured and fit for the table." (Merriam, "Birds of Connecticut," p. 67.) Dr. Fisher calls this Ow1 the most destructive to poultry of all our birds of prey; with the possible exception of the Goshawk and Cooper's Hawk, and quotes Dr. P. R. Hoy as writing, "The specimen in the collection of the Academy was known to carry off from one farm, in the space of a month, not less than twenty-seven individuals of various kinds of poultry before it was shot." Of the 127 stomachs reported by him, 3 I contained poultry or game birds; 8 , other birds; 13 , mice; 65 , other mammals; 1 , a scorpion; 1 , fish ; Io, insects; and I7 were empty. Of 16 examined by Dr. Warren, I I contained poultry; 2, rabbits; 2, mice; I, a mammal; and I, insects. Of 3 stomachs examined by the author, I was empty; I contained a mass of bones and feathers, including those of a Robin and Crow ; and I, many small birds. In a nest containing three young just hatched, visited by him on March 9, 1904, was a dead Screech Owl and three mice. The bodies of II 3 rats, chiefly killed within the last ten days, have been found under a nest of this owl containing young. Little claim has this bird to our protection, but it is rare through most of the state.

Our other five Owls are all useful, some of them almost exclusively so, and should be afforded full protection.

The Barred Owl (Strix varia varia) is next in size to the Great Horned Owl, and much more common, especially near the coast. While its food is largely the same as that of the last species, its incursions into the poultry yard are less frequent, its pursuit of game less eager, and its relish for mice and other injurious mammals far greater. A taste for small owls frequently indulged in by this species must be counted against it, as these owls are altogether useful. Dr. Fisher reports finding the remains of small owls in seven stomachs of these birds, and quotes two 
incidents of Screech Owls having thus been found by others. Several times in pellets, probably of this owl, found in the woods near New Haven, the author has noticed feathers of Screech and Saw-whet Owls, and once found the latter in the stomach of a Barred Owl. Of 109 stomachs reported by Dr. Fisher, 5 contained poultry or game; 13 , other birds; 46 , mice; 18 , other mammals; 4, frogs; I, a lizard; 2, fish; I4, insects; 2, spiders ; 9, crawfish; and 20 were empty. Of 8 stomachs examined by Dr. Warren, 4 contained mice; 2, other mammals; 2, poultry; 2 , other birds; and 4, beetles. Of 14 examined by the author, 7 were empty; 6 contained mammals - mice and squirrels; and I, a Saw-whet Owl.

The Short-eared Owl (Asio flammeus) is with us only in the fall and early spring, when it inhabits our marshes. The chief food of this bird is mice, and there are many accounts of the manner in which these owls have flocked to the infested district, when different parts of Europe have suffered with plagues of these animals. Of IOI stomachs reported by Dr. Fisher, I I contained small birds; 77 , mice; 7 , other mammals; 7 , insects; and I4 were empty. Of I I stomachs reported by Dr. Warren, all contained mice; and 2, beetles. Three stomachs examined by the author in Alaska contained either mice or shrews; and one examined by Mr. E. T. Judd in North Dakota contained a mouse and grasshoppers.

But there is another side to this picture that should not be forgotten, useful on the whole as the Short-eared Owl must be considered. One stomach of a California bird examined by the author contained a blackbird; and the stomachs of four Connecticut birds held only birds, including a Meadowlark and sparrows; while at the spots these owls frequent on our salt marshes he has found many evidences of their destructiveness to birds, including once feathers of a Yellow Rail, and pellets containing those of the Meadowlark, Robin, and Towhee. Another serious deviation from a mice diet has been reported by Mr. William Brewster (Bulletin Nuttall Ornithological Club, Vol. 4, 1879, p. 19). He found in June, I870, a small colony of these owls living among the terns of Muskeget Island, and noticed in the grass of their retreat the remains of at least 100 terns that they had killed. The breast only had been eaten in each instance. 
More consistently useful than either of these Owls is the Long-eared Owl (Asio wilsonianus); for its food is almost wholly field mice, as many as eight having been found in one stomach; and it is deserving of most thorough protection. It is by no means common through most of the state, and is usually shot at sight. Dr. Warren writes: "I have examined the stomachs of twenty-three Long-eared Owls, and found that twenty-two of them had fed only on mice; the other examination made of a specimen taken in the late spring, showed some beetles and portions of a small bird." Dr. Fisher reports that, of IO7 stomachs examined, I contained a game-bird; I5, other birds; 84 , mice; 5 , other mammals; 1 , insects; and I5 were empty. Of 14 examined by the author, 6 were empty; the other 8 all contained mammals, chiefly mice; and $\mathrm{r}$, a small bird.

About the villages and orchards the little Screech Owl (Otus asio asio) is by far the most abundant of our owls, and undoubtedly helps in keeping down the number of English Sparrows, although mice and insects are the chief diet. It has been known to kill quail and woodcock, though rarely; and once sixteen horned pouts were found in the nest of this bird in the depth of winter. All authorities agree that its food in summer consists chiefly of insects. Mr. George C. Jones of Brookfield Center, Connecticut, writes in Dr. Fisher's work that he has found cutworms in the stomachs of the Long-eared Owl and this species, and believes these birds the most efficient exterminators of this pest so formidable to tobacco growers. Of 255 stomachs reported by Dr. Fisher, I contained poultry; 38 , other birds; 91, mice; II, other mammals; 2 , lizards ; 4 , batrachians; I, fish; 100, insects; 5, spiders; 9, crawfish; 2, scorpions; 2, earthworms; 7, miscellaneous material; and 43 were empty. Of 27 stomachs examined by Dr. Warren, 20 contained mice and insects; 5, small birds; and 2, small birds and insects. Of 7 examined by the author, 3 were empty; 3 contained mammals, chiefly mice; and $\mathrm{I}$, insects.

Our smallest owl, the Saw-whet or Acadian (Cryptoglaux acadica acadica) seems to be rare throughout the state, and has only been taken at all frequently during the winter. Many of those recorded have been found dead, apparently starved. Mice are almost its only food, although an entire flying squirrel has 
been reported in the stomach of this bird. Of 22 stomachs reported by Dr. Fisher, I7 contained mice; I, a bird; I, an insect; and 3 were empty. Of 4 stomachs examined by the author, 3 contained mice; and I was empty.

The Snowy Owl (Nyctea nyctea) is a rare winter resident in the state, most common near the seashore. Dr. Fisher finds it a useful bird. Of 38 stomachs examined by him, 2 contained game birds; 9 , other birds; 18 , mice; 2 , other mammals; and 12 were empty.

\section{CUCKOOS.}

Cuculida.

Especially deserving of protection are our Cuckoos, the Black-billed (Coccyzus erythrophthalmus), and the Yellowbilled (Co.cyzus americanus americanus); as they feed chiefly on the caterpillars that infest the trees of the woods and orchards, and are among the few birds that eat the hairy species. "In fact, cuckoos eat so many hairy caterpillars that the hairs pierce the inner lining of the stomach and remain there, so that, when the stomach is opened and turned inside out, it appears to be lined with a thin coating of fur." (Beal, "Some Common Birds in Relation to Agriculture.")

"The insect food of cuckoos consists of beetles, grasshoppers, cicadas, bugs, ants, wasps, flies, caterpillars, and spiders, of which grasshoppers and caterpillars constitute more than three-fourths. The great majority of the insects found in the stomachs were harmful kinds. Caterpillars, katydids, and tree crickets are exactly the prey that cuckoos might be expected to secure, from their peculiar method of hunting in foliage; while the large numbers of grasshoppers eaten furnish additional proof of the fact so often illustrated that birds are particularly fond of grasshoppers, and that species not naturally ground feeders become so during the grasshopper season.

"It is a matter of common observation that cuckoos feed largely on caterpillars; and stomach investigations not only confirm this, but show that, unlike most other birds, they eat freely of hairy and bristly species. Nearly half of the cuckoo's food was found to be caterpillars. An attempt was made to obtain an approximate idea of the actual number in the stomachs by 
counting the heads and jaws; but in many cases this was nearly impossible, as many of the insects were very young and the jaws consequently minute. The result of this estimate, however, showed that no less than 2,77I caterpillars were contained in 129 stomachs, or an average of more than $2 \mathrm{I}$ in each. If the whole number of stomachs (I55) is considered, the average is reduced to I8; and it is absolutely certain that this is much below the actual number.

"During May and June, when tent caterpillars are defoliating the fruit trees, these insects constitute half of the Cuckoo's food. When Cuckoos visit the nest of the tent caterpillars they apparently eat as many of the occupants as possible. Most of the stomachs that contained the larvæ at all were filled with them, some having more than 100 individuals." (Beal, "The Food of Cuckoos.")

"An examination of the stomachs of 16 Black-billed Cuckoos, taken during the summer months, showed the remains of 328 caterpillars, II beetles, I 5 grasshoppers, 63 sawflies, 3 stink-bugs, and 4 spiders." "Of the Yellow-billed Cuckoo, 2I stomachs, collected from May to October, inclusive, were examined. The contents consisted of 355 caterpillars, 18 beetles, 23 grasshoppers, 3I sawflies, I4 bugs, 6 flies, and I2 spiders. As in the case of the Black-billed Cuckoo, most of the caterpillars belonged to hairy species, and many of them were of large size." (Beal, "Some Common Birds in their relation to Agriculture.")

\section{KINGFISHERS.}

\section{Alcedinida.}

The Belted Kingfisher (Ceryle alcyon) feeds chiefly on small fish, the vast majority of which are of no economic value. Mice, frogs, and grasshoppers are also said to be occasionally captured, and the young are fed with various aquatic insects. (Weed and Dearborn, "Birds in their Relation to Man.") Its chief value, however, is an æsthetic one, the boldly marked form and noisy rattle adding interest to the shore of lake, river, and sound. 


\section{WOODPECKERS.}

\section{Picide.}

Of the four Woodpeckers that now occur in any numbers in Connecticut, the Yellow-bellied Sapsucker (Sphyrapicus varius varius) is the only harmful species; and it is with us only as a tolerably common spring and fall migrant. This is the species that drills the series of small circular openings so often found on the trunks of apple trees, to eat the inner layer of bark and drink the sap that exudes into these tiny cups. Birches and the mountain ash are favorites with this bird, on account of their abundant sweet sap; and the trees are sometimes killed by too persistent tapping. In the Turtle Mountains of North Dakota the author has noticed that most of the larger birches that showed evidences of this bird's work were dead at the top. But not alone for the sap and bark does the sapsucker drill these holes; he has a choice feast from the insects that are attracted (Merriam, Bulletin Nuttall Ornithological Club, Vol. 4, I879, p. 3). A certain amount of insect food is necessary to the species at least in youth; for young birds fed as exclusively as possible on a diet of maple syrup died with the symptoms of starvation, and the stomachs of eight adults shot in June and July were full of insects. (Bolles, The Auk, Vol. 8, 1891, p. 269, and Vol. 9, I892, p. II9.)

Professor Beal reports that in $3^{1} 3$ stomachs examined the vegetable part more than equaled the animal; 34.3 I per cent of the entire food consisted of ants, the rest of the animal portion being wasps, beetles, flies, bugs, grasshoppers, crickets, and Mayflies; while the chief items of the vegetable portion are fruit and cambium. (Beal, "Food of the Woodpeckers of the United States.”)

Our commonest and smallest Woodpecker, the Downy, (Dryobates pubescens medianus) is also the most useful. In I40 stomachs Prof. Beal reports there was found 74 per cent of insects, 25 per cent of vegetable matter, and I per cent of mineral matter or sand. "The ants constitute almost one-third of all the animal food, or about 23 per cent of the whole, indicating a very decided taste for this rather acid and highly flavored article of diet. Beetles stand a little higher in order of importance, amounting to about one-third of the entire insect food, or somewhat more 
than 24 per cent of all. Many of these belong to the family of May-beetles, a few were the predaceous ground beetles, but by far the greatest number were wood-boring larvæ - a fact showing that this little bird, while securing his dinner, is doing good work for the forest. One-fifth of the animal food, or I6 per cent of the total, consists of caterpillars, many of which apparently are wood-boring species; others are kinds that live on stems and foliage. Among insects the most interesting are the bugs (Hemiptera), which are represented in the stomachs by several species, notably by plant lice (Aphides), which in several instances were found in considerable quantities, amounting to 4 per cent of the whole food." (Beal, "Preliminary Report on the Food of Woodpeckers.")

In the vegetable food were found the seeds of different berries, including poison ivy. It thus becomes evident that these little birds are not engaged in harming the trees, when we see them pecking from limb to limb, but hunting for wood-boring insects and the like.

The great usefulness of the Downy Woodpecker has been in recent years abundantly proved by more extended observations of the Biological Survey. The contents of 723 stomachs consisted of 76.05 per cent of animal matter and only 23.95 per cent of vegetable. "The foregoing discussion of the Downy Woodpecker shows it to be one of our most useful species. The only complaint against the bird is on the score of disseminating the poisonous species of Rhus. However, it is fortunate that the bird can live on this food when it is difficult to procure anything else. The insect food selected by the Downy is almost all of species economically harmful." (Beal, "Food of the Woodpeckers of the United States.")

The food of the Hairy Woodpecker (Dryobates villosus villosus) is much the same as that of the Downy, but the vegetable percentage is somewhat greater.

The Flicker, or Yellow-hammer (Colaptes auratus luteus), the largest of our common woodpeckers and the most abundant near the coast in the fall, lives largely on ants, over 2,000 having been found in each of two stomachs by Professor Beal. As ants protect and help to spread plant lice of various species, their destruction by the Flicker is advantageous. Professor Beal found, 
in 230 stomachs examined, 56 per cent of animal matter, 39 per cent of vegetable, and 5 per cent of mineral. More than threefourths of the animal matter consisted of ants, but spiders, beetles, and myriapods were also present. Of the vegetable matter, corn and buckwheat were found in only six stomachs, the rest consisting of various berries and seeds, many of them those of weeds. In a later report, Professor Beal státes that 60.92 per cent of the contents of 684 stomachs was animal matter, and 39.08 per cent vegetable. "It eats only a few predaceous ground beetles. The remainder of the animal food is entirely of harmful species. In its vegetable diet, grain and fruit are the only useful products eaten, and the quantities are insignificant. The bird, like many others, has the bad habit of sowing broadcast the seeds of the poison Rhus, but there seems no remedy for this." (Beal, "Food of the Woodpeckers of the United States.")

\section{NIGHTHAWKS and WHIP-POOR-WILLS.}

Caprimulgida.

The Whip-poor-will (Antrostomus vociferus vociferus) and the Nighthawk (Chordeiles virginianus virginianus) subsist almost entirely on the different night-flying insects. Moths, beetles, and injurious grasshoppers form a large portion of the food of the Whip-poor-will (Weed and Dearborn); and Mr. Nash found the stomach of one filled with large wingless ants (Nash, "Birds of Ontario"). Flying Nighthawks shot in the evening by the author in North Dakota have almost invariably had the entire throat crowded full of insects, and the thick coating of fat on these birds shows how abundant they find this food. "It is a great insect eater, its food consisting of May-flies, dragon-flies, beetles of many kinds, water-boatmen, scorpion-flies, bugs of various sorts, and many grasshoppers. From seven Nebraska specimens Professor Aughey took three hundred and forty-eight Rocky Mountain locusts, an average of forty-nine to each bird. An Arkansas specimen examined by F. L. Harvey contained more than six hundred insects - gnats, beetles, flies, ants, and grasshoppers. Professor Herrick has found that the young are fed largely on firefly beetles." (Weed and Dearborn.) Yet this bird, whose whole existence is given to keeping insect pests under, is shot in wantonness by almost every boy with a gun, until it is 
now seldom seen, though formerly common in every rocky pasture throughout the state.

\section{SWIFTS.}

\section{Micropodide.}

The Chimney Swift (Chctura pelagica) also feeds entirely on insects; and the number of these it must capture each day is indicated by the writhing mass in its throat, when it has coursed an hour or so through the air. "Their food is varied, probably consisting of almost all the flying insects with which they come in contact. Three specimens studied by Professor S. A. Forbes had eaten ants, moths, ground beetles, rove-beetles, plant beetles, flies, bugs, and spiders. The young are fed largely upon grasshoppers when these are abundant, and at other times on various kinds of insects." (Weed and Dearborn.)

\section{HUMMINGBIRDS.}

\section{Trochilide.}

Although the few small insects which our solitary Hummingbird, the Ruby-throated (Archilochus colubris), eats while sipping the honey from flowers, or the sap at the cups of the Sapsucker, may not be of economic importance, its beauty should certainly gain our protection.

\section{FLYCATCHERS.}

\section{Tyrannide.}

As their name implies, the Flycatchers are insect eaters. These they obtain chiefly by darting from a limb or post and seizing them in the air, but occasionally hunt for them on the ground. Only five species of them are common enough with us to be of any economic importance, and of these the Kingbird (Tyrannus tyrannus) is the largest and most numerous. Locally known as "Bee Martin" on account of its supposed fondness for bees, this bird has obtained an evil reputation that seems to be undeserved. Mr. Nash quotes a Mr. Thaddeus Smith as writing, "I have been here over thirty years, and at one time made the science of apiculture a special study, raising choice 
Italian queens, etc. Kingbirds are here every season, and are to be seen around my beehives. Years ago I killed some and examined their stomachs, and found them full of bees, but nearly every bee in them was a drone; I found only one worker bee. You know the drones have no sting, and, as their name implies, they are of no use in the hive. They are the male bees, and their only use is to fertilize the queen bee. The only damage the Kingbird can do is that they might sometimes catch the young queen while on her wedding flight, as her size and slow flight make her quite conspicuous. But the possibility of this happening is so slight that I never now shoot the Kingbird." (Nash, "Birds of Ontario in relation to Agriculture.")

"The Kingbird manifests its presence in many ways. It is somewhat boisterous and obtrusive, and its antipathy for hawks and crows is well known. It never hesitates to give battle to any of these marauders, no matter how superior in size, and for this reason a family of Kingbirds is a desirable adjunct to a poultry yard. On one occasion in the knowledge of the writer, a hawk which attacked a brood of young turkeys was pounced upon and so severely buffeted by a pair of Kingbirds, whose nest was near by, that the would-be robber was glad to escape without his prey. Song birds that nest near the Kingbird are similarly protected."

"The Biological Survey has made an examination of 28I stomachs collected in various parts of the country, but found only I4 containing remains of honeybees. In these I4 stomachs there were in all 50 honeybees, of which 40 were drones, 4 were certainly workers, and the remaining 6 were too badly broken to be identified as to sex.

"The insects that constitute the great bulk of the food of this bird are noxious species, largely beetles - May beetles, click beetles (the larvæ of which are known as wireworms), weevils, which prey upon fruit and grain, and a host of others. Wasps, wild bees, and ants are conspicuous elements of the food, far outnumbering the hive bees. During summer many grasshoppers and crickets, as well as leaf-hoppers and other bugs, are also eaten. Among the flies were a number of robber flies - insects which prey largely upon other insects, especially honeybees, and which have been known to commit in this way extensive depredations. It is thus evident that the Kingbird by destroying 
these flies actually does good work for the apiarist. Nineteen robber flies were found in the stomachs examined; these may be considered more than an equivalent for the four worker honeybees already mentioned. A few caterpillars are eaten, mostly belonging to the group commonly known as cutworms, all the species of which are harmful. About ro per cent of the food consists of small native fruits, comprising some twenty common species of the roadsides and thickets, such as dogwood berries, elderberries, and wild grapes. The bird has not been reported as eating cultivated fruit to an injurious extent; and it is very doubtful if this is ever the case, for cherries and blackberries are the only ones that might have come from cultivated places, and they were found in but few stomachs.

"Three points seem to be clearly established in regard to the food of the Kingbird-(I) that about 90 per cent consists of insects, mostly injurious species; (2) that the alleged habit of preying upon honeybees is much less prevalent than has been supposed, and probably does not result in any great damage; and (3) that the vegetable food consists almost entirely of wild fruits, which have no economic value. These facts taken in connection with its well-known enmity for hawks and crows, entitle the Kingbird to a place among the most desirable birds of the orchard or garden." (Beal, "Some Common Birds in Relation to Agriculture.")

The Phœbe (Sayornis phobe), according to Professor Beal "subsists almost exclusively upon insects, most of which are caught upon the wing. An examination of 80 stomachs showed that over 93 per cent of the year's food consists of insects and spiders, while wild fruit constitutes the remainder. The insects belong chiefly to noxious species, and include many click beetles, May beetles, and weevils. Grasshoppers in their season are eaten to a considerable extent, while wasps of various species, many flies of species that annoy cattle, and a few bugs and spiders are also eaten regularly. It is evident that a pair of phœbes must materially reduce the number of insects near a garden or field, as the birds often, if not always, raise two broods a year, and each brood numbers from four to six young.

"The vegetable portion of the food is unimportant, and consists mainly of a few seeds, with small fruits, such as wild 
cherries, elderberries, and juniper berries. The raspberries and blackberries found in the stomachs were the only fruits that might have belonged to cultivated varieties, and the quantity was trifling.

"There is hardly a more useful species than the Phobe about the farm, and it should receive every encouragement. To furnish nesting boxes is unnecessary, as it usually prefers a more open situation, like a shed, or a nook under the eaves, but it should be protected from cats and other marauders." (Beal, "Some Common Birds in Relation to Agriculture.")

The Wood Pewee (Myiochanes virens) was found by Professor King to feed largely on small beetles and dipterous insects, including large crane-flies; and the Least Flycatcher (Empidonax minimus) to eat beetles, Diptera, and Hymenoptera. (Chapman, "Economic Value of Birds to the State.")

Of the Least Flycatcher (Empidonax minimus) Professor Forbush says, "Like all Flycatchers, this species catches flies, among them the common house fly, and also some useful parasitic flies. It is by no means confined to such food, however, but is particularly destructive to small beetles in flight, and in this respect it is most useful. It captures many moths, particularly those species that fly by day, as the gypsy moth; but it also picks up many which are stirring only very early in the morning or at evening. The bird watches for caterpillars, and, when it sees one stir, flies from its perch and snaps up the luckless creature. The bird, in common with other Flycatchers, picks up many caterpillars that, to escape Warblers and other enemies, spin down on their webs or drop from the trees. The greatest service our little Flycatcher renders to man consists of the destruction of such orchard pests as boring beetles, bark beetles, the fly of the railroad worm, codling moths, gipsy moths, cankerworms, and other caterpillars." (Forbush, "Useful Birds and their Protection.")

\section{LARKS.}

\section{Alaudida.}

Our Horned Lark (Otocoris alpestris alpestris) feeds almost entirely on seeds of various weeds. One examined by Dr. Judd had in the stomach " a bit of a kernel of corn, 4 seeds of lamb's- 
quarters, 8 of crab-grass, Io of bastard pennyroyal, and 12 of ragweed" (Judd, "Birds of a Maryland Farm").

\section{CROWS and JAYS.}

\section{Corvide.}

Of the Blue Jay (Cyanocitta cristata cristata) Professor Beal says, "Ornithologists and field observers in general declare that a considerable portion of its food in spring and early summer consists of the eggs and young of small birds, and some farmers accuse it of stealing corn to an injurious extent in the fall. While there may be some truth in these accusations, they have almost certainly been exaggerated. No doubt many jays have been observed robbing nests of other birds, but thousands have been seen that were not so engaged.

"In an investigation of the food of the Blue Jay, 292 stomachs were examined, which showed that animal matter comprised 24 per cent and vegetable matter 76 per cent of the bird's diet. So much has been said about the nest-robbing habits of the Jay that special search was made for traces of birds or birds' eggs in the stomachs, with the result that shells of small birds' eggs were found in three, and the remains of young birds in only two stomachs.

"Such negative evidence is not sufficient to controvert the great mass of testimony upon this point, but it shows that the habit is not so prevalent as has been believed. Besides birds and their eggs, the Jay eats mice, fish, salamanders, snails, and crustaceans, which altogether constitute but little more than I per cent of its diet. The insect food is made up of beetles, grasshoppers, caterpillars, and a few species of other orders, all noxious, except some $3 \frac{1}{2}$ per cent of predaceous beetles. Thus something more than I9 per cent of the whole food consists of harmful insects. In August the Jay, like many other birds, turns its attention to grasshoppers, which constitute nearly one-fifth of its food during that month. At this time, also, most of the other noxious insects, including caterpillars, are consumed, though beetles are eaten chiefly in spring.

"The vegetable food is quite varied, but the item of most interest is grain. Corn was found in 70 stomachs, wheat in 8 , and oats in 2-all constituting 19 per cent of the total food. 
Corn is evidently the favorite grain, but a closer inspection of the record shows that the greater part was eaten during the first five months of the year, and that very little was taken after May, even in harvest time, when it is abundant. This indicates that most of the corn is gleaned from the fields after harvest, except what is stolen from cribs or gathered in May at planting time.

"The Jay's favorite food is mast (i. e., acorns, chestnuts, chinquapins, etc.), which was found in 158 of the 292 stomachs, and amounted to more than 42 per cent of the whole food. In September corn formed I5 and mast 35 per cent; while in October, November, and December corn dropped to an almost inappreciable quantity, and mast amounted to 64,82 , and 83 per cent, respectively. And yet in these months carn is abundant and everywhere easily accessible. The other elements of food consist of a few seeds and wild fruits, among which grapes and blackberries predominate.

"The results of the stomach examination show (I) that the Jay eats many noxious insects; (2) that its habit of robbing the nests of other birds is much less common than has been asserted; and (3) that it does little harm to agriculture, since all but a small amount of the corn eaten is waste grain." (Beal, "Some Common Birds in Their Relation to Agriculture.")

In another paper - "The Blue Jay and its Food,"- Professor Beal cites several instances of the Jay destroying the eggs or young of smaller birds; and we agree with the verdict of Mr. Frank M. Chapman: "Personally, my attitude toward the Jay is that which I hold in regard to the Crow. It is not unusual for the Jay to eat birds' eggs, and in so doing he does an injury which the good deeds to his credit are far from balancing. As with the Crow, any one of the insect or seed eating birds killed by a Jay would doubtless have been more desirable than the Jay itself; and, where a single Jay, as often happens, destroys a whole nestful of eggs, it becomes a positively injurious species. I believe, therefore, that the Blue Jay is no more deserving of protection than is the Crow. Both birds, however, are far too interesting to be exterminated, but no steps should be taken which will result in their increase. Belonging to a family noted for the intelligence and adaptability of its members, Crows and Jays can adjust themselves to the changes incident to civilization 
far more readily than any of the birds which become their victims; and, in cases of this kind, man should help to restore nature's balance by according protection to the weaker species; not to their enemies." (Chapman, "Economic Value of Birds to the State.")

Regarding the Crow (Corvus brachyrhynchos brachyrhynchos), the evidence is about the same as with the Blue Jay; and it is probable that the good this bird does in destroying grasshoppers, cutworms, etc., is far outweighed by the evil in killing the young of insectivorous birds. "There are few birds so well known as the common Crow, and, unlike most other species, he does not seem to decrease in numbers as the country becomes more densely populated.

"The Crow is commonly regarded as a blackleg and a thief. Without the dash and brilliancy of the Jay, or the bold savagery of the Hawk, he is accused of doing more mischief than either. That he does pull up sprouting corn, destroy chickens, and rob the nests of small birds, has been repeatedly proved. Nor are these all of his sins. He is known to eat frogs, toads, salamanders, and some small snakes - all harmless creatures that do some good by eating insects. With so many charges against him, it may be well to show why he shoulel not be utterly condemned.

"The examination of a large number of stomachs, while confirming all the foregoing accusations, has thrown upon the subject a. light somewhat different from that derived solely from field observations. It shows that the bird's-nesting habit, as in the case of the Jay, is not so universal as has been supposed; and that, so far from being a habitual nest-robber, the Crow only occasionally indulges in that reprehensible practice. The same is true in regard to destroying chickens, for he is able to carry off none but very young ones, and his opportunities for capturing them are somewhat limited. Neither are many toads and frogs eaten; and, as frogs are of no great practical value, their destruction is not a serious matter; but toads are very useful, and their consumption, so far as it goes, must be counted against the Crow. Turtles, crayfishes, and snails, of which he eats quite a large number, may be considered neutral, while mice may be counted to his credit. 
"In his insect food, however, the Crow makes amends for sins in the rest of his dietary, although even here the first item is against him. Predaceous beetles are eaten in some numbers throughout the season, but the number is not great. May beetles, dor-bugs, or June bugs, and others of the same family, constitute the principal food during spring and early summer, and are fed to the young in immense quantities. Other beetles, nearly all of a noxious character, are eaten to a considerable extent. Grasshoppers are first taken in May, but not in large numbers until August, when, as might be expected, they form the leading article of diet, showing that the Crow is no exception to the general rule that most birds subsist, to a large extent, upon grasshoppers in the month of August. Many bugs, some caterpillars, most cutworms, and some spiders are also eaten - all of them either harmful or neutral in their economic relations. Of the insect diet Mr. E. A. Schwarz says: 'The fact, on the whole, speaks overwhelmingly in favor of the Crow.'

"Probably the most important item in the vegetable food is corn, and by pulling up the newly sprouted seeds the bird renders himself extremely obnoxious. Observation and experiments with tame crows show that hard, dry corn is never eaten if anything else is to be had, and, if fed to nestlings, it is soon disgorged. The reason crows resort to newly planted fields is that the kernels of corn are softened by the moisture of the earth, and probably become more palatable in the progress of germination, which changes the starch of the grain to sugar. The fact, however, remains that crows eat corn extensively only when it has been softened by germination or partial decay, or before it is ripe and still 'in the milk.' Experience has shown that they may be prevented from pulling up young corn by tarring the seeds, which not only saves the corn, but forces them to turn their attention to insects. If they persist in eating green corn, it is not so easy to prevent the damage; but no details of extensive injury in this way have yet been presented, and it is probable that no great harm has been done.

"Crows eat fruit to some extent, but confine themselves for the most part to wild species, such as dogwood, sour gum, and seeds of the different kinds of sumac. They have also a habit of sampling almost everything which appears eatable, especially 
when food is scarce. For example, they eat frozen apples found on the trees in winter, or pumpkins, turnips, and potatoes which have been overlooked or neglected; even mushrooms are sometimes taken, probably in default of something better.

"In estimating the economic status of the Crow, it must be acknowledged that he does some damage, but, on the other hand, he should receive much credit for the insects which he destroys. In the more thickly settled parts of the country the Crow probably does more good than harm, at least when ordinary precautions are taken to protect young poultry and newly planted corn against his depredations. If, however, corn is planted with no provision against possible marauders, if hens and turkeys are allowed to nest and to roam with their broods at a distance from farm buildings, losses must be expected." (Beal, "Some Common Birds in Their Relation to Agriculture.")

"While, from the nature of the case, birds' eggs and young can form but a small portion of the annual food supply of the Crow, I believe it to be indisputable that during the nesting season they constitute a large percentage of the Crow's food. Nestrobbing is not occasional, but is the characteristic habit of the Crow. Not, only do they eat eggs and young birds, but they feed their offspring on them. Doubtless few Crows live through May and June without preying on smaller birds, and the possibilities are that almost any one of the birds destroyed (either in the egg or out of it) is of greater economic value than the Crow. The Crow, therefore, in addition to the direct damage it may do our crops, robs us of the services of birds far more desirable than itself. Even if the Crow, aside from its canniballike propensities, was wholly beneficial, it would not, it seems to me, render us as great a service as would have been performed by the birds it destroys. In short, in my opinion, the Crow is one of the worst enemies of our small insectivorous and seedsating birds, and as such it is undeserving of protection." (Chapman, "Economic Value of Birds to the State.")

\section{STARLINGS.}

\section{Sturnida.}

As the Starling (Sturnus vulgaris) is now so firmly settled along the coast as far east as New Haven that its distribution 
through the rest of the state seems only a matter of time, it is important for us to know whether we should welcome it, or are receiving another undesirable immigrant. The evidence appears on the whole to be adverse to the good character of this bird, and is thus given by Dr. T. S. Palmer: "The Starling (Sturnus vulgaris) of Europe and western Asia is one of the best-known birds of the Old World, and during late years has been increasing in numbers in the British Isles. It is sometimes accused of stealing fruit and destroying nests and eggs of other birds, but in its native home it seems to be beneficial rather than otherwise. Comparatively little accurate information concerning its food habits is available, except the results of an examination of 175 stomachs recently made in Scotland by Mr. John Gilmour. According to this examination, the food consists of 75 per cent insects, 20 per cent grain (mainly waste grain), and 5 per cent miscellaneous substances. Some useful insects were eaten, but the greater proportion were classed as injurious. The charge of destroying eggs of larks, and occasionally young nestlings, was not substantiated; as no egg shells were found in these stomachs. Mr. Gilmour calls attention to the rapid increase of starlings in Fifeshire, thousands now existing where fifty or sixty years ago they were considered rare; and mentions the serious damage sometimes done to shrubs and young plantations when occupied as roosting places, but concludes that on the whole the bird is beneficial and worthy of protection."

"Much has been said concerning the advantages of introducing the Starling into this country; but, in spite of the many arguments brought forward, the bird's character is not above suspicion, and its usefulness is still open to question. The fact seems to have been overlooked that in other countries the Starling has signally failed to fulfill the expectations concerning its usefulness. Certainly the experience of Australia and New Zealand offers little encouragement. It was introduced in New Zealand in 1867 , and as early as 1870 was reported as 'becoming very numerous.' It seems to have increased very rapidly; and, in spite of its natural preference for insects, in its new home it has adopted a fruit diet to such an extent as to become a great pest. In South Australia it was reported to be common in certain localities in 1894, and measures for its extermination were 
considered. In Victoria, on the other hand, steps were taken in I 895 to promote its increase in fruit and grain growing districts, and this fact was used as an argument in its favor by persons who were endeavoring to introduce it into some of the other colonies. Western Australia has taken a firm stand on the question, and Mr. R. Helms, Biologist of the Bureau of Agriculture of that colony, who opposed the proposed importation, gives his reasons as follows: 'Had I been asked fifteen or twenty years ago what I had to say, I would probably have recommended their introduction. But not so now. My experience has taught me better. The birds were introduced more than fifteen years ago into New Zealand, and now, like the thrushes, they have become a pest to fruit growers. They have changed their habit, from being principally insectivorous having become omnivorous.'

"After due deliberation, the Government issued a proclamation on January 22, I896, declaring the Starling a destructive bird, and absolutely prohibiting its importation into Western Australia. Still more recently it has been condemned in Tasmania, where it is charged with committing. depredations on small fruits, cherries, and wheat. Its further distribution has been discouraged; and, when the question of introducing several species of birds was under discussion at an agricultural conference at Scottsdale on December 6, I897, the Starling was promptly rejected." (Palmer, "Danger of Introducing Noxious Animals and Birds.")

Since the above was written Starlings have multiplied greatly, have spread to Rhode Island, western Massachusetts, New Jersey, and Pennsylvania, and are frequently found in flocks of thousands in fall, especially in the neighborhood of the salt marshes, where they assemble for the night. Besides the actual damage which they do to grain, etc., they seize all the hollow limbs in orchards, which the far more useful native birds have been accustomed to utilize for nesting; and more than once pairs of Starlings have been seen to attack and drive away even such a powerful bird as the Flicker from the cavity which it had just finished excavating. In our own State Mr. Wilbur F. Smith has reported instances of their damaging apples on the trees and of one having been seen flying from a tree with a Robin's egg in its bill. (Bird-Lore, $\mathrm{X}, \mathrm{rg08,}$ p. 79.) Its enmity toward our other undesirable immi- 
grant - the English Sparrow - is its chief claim to our consideration.

\section{BLACKBIRDS, ORIOLES, etc.}

\section{Icterida.}

The Blackbirds, from their habit of collecting in late summer in enormous flocks and descending upon the grain fields, have enjoyed since the first settlement of New England a bad reputation, which the experts in the Department of Agriculture inform us is better deserved than that of some other ostracized species. Dr. Merriam quotes ("Birds of Connecticut," p. 46), a law passed in Lynn, March 8, 1697, "That every householder in the town, should sometime before the fifteen day of May next, kill or cause to be killed, twelve blackbirds, . . . . and if any householder as aforesaid shall refuse or neglect to kill and bring in the heads of twelve blackbirds, as aforesaid, every such person shall pay three pence for every blackbird that is wanting, as aforesaid, for the use of the town." He quotes also from Peter Kalm's "Travels in North America": "Their chief and most agreeable food is maize. They come in great swarms in spring, soon after the maize is put under ground. They scratch up the grains of maize and eat them. As soon as the leaf comes out, they take hold of it with their bills, and pluck it up, together with the corn or grain; and thus they give a great deal of trouble to the country people, even so early in spring." Again in fall, "They assemble by thousands in the maize fields, and live at discretion. They are very bold; for, when they are disturbed, they only go and settle in another part of the field. In that manner, they always go from one end of the field to the other, and do not leave it till they are quite satisfied. They fly in incredible swarms in autumn; and it can hardly be conceived whence such immense numbers of them should come. When they rise in the air they darken the sky, and make it look quite black. . . . As they are so destructive to maize, the odium of the inhabitants against them is carried so far that the laws of Pennsylvania and New Jersey have settled a premium of three pence a dozen for dead maize-thieves. In New England, the people are still greater enemies to them; for Dr. Franklin told me, in the spring of the year 1750 , that, by means of the 
premiums which have been settled for killing them in New England, they have been so extirpated, that they are very rarely seen, and in a few places only. But as, in the summer of the year 1749 , an immense quantity of worms appeared on the meadows, which devoured the grass, and did great damage, the people have abated their enmity against the maize-thieves; for they thought they had observed that those birds lived chiefly on these worms before the maize is ripe, and consequently extirpated them, or at least prevented their spreading too much. They seem therefore to be entitled, as it were, to a reward for their trouble."

Regarding these birds Professor Beal writes ("Birds that Injure Grain"): "Stomach investigation shows conclusively that birds do not subsist upon grain alone, even at times when it is possible to obtain it. Moreover, the greatest amount of grain is not eaten at harvest time, but during the winter months, when other food is scarce and waste kernels can be picked up in the fields. If any kind of grain is preferred by a certain species, we should expect the bird to subsist upon that almost exclusively when it can be obtained, that is, at harvest time. That this is not the case, is shown by the fact that many birds of the same species have been shot at the same time in a grain field, and, while some stomachs were full of grain, others were only partly filled, and still others were wholly filled with other food. So many cases of this kind have occurred that it seems practically certain that few birds willingly subsist exclusively upon any kind of grain for a considerable length of time. With many species this is in notable contrast to their marked fondness for the seeds of certain useless plants, upon which at some seasons they subsist almost entirely.

"If it be admitted that birds do not as a rule display an inordinate appetite for grain, the question naturally arises: What is the cause of the tremendous ravages they sometimes commit? Both stomach examination and field observation point to the same answer: Too many birds of the same or closely allied species are gathered together within a limited area.

"An attempt to exterminate these species would be not only ill-advised but hopeless. States have offered bounties for their destruction without perceptibly thinning their ranks. Is there, then, any remedy for evil? The writer is forced to confess 
that he has none to suggest, except in the case of crows and blackbirds that pull up sprouting corn. This can be prevented by thoroughly tarring the seed, which, if properly done, neither injures its vitality nor prevents the use of machinery in planting. There is, however, some hope for the future, though perhaps a distant one. While the advance of civilization has thus far not affected these birds or their haunts, the time must surely come when it will. Increased density of population will broaden the area of cultivation, and this in time must lead to the draining of the smaller marshes and ponds, thus turning over to agriculture much land that has heretofore been worse than waste, since it has served as a breeding ground for the birds that have destroyed the crops. With the breeding places more restricted, and an environment otherwise changed by increased population, the number of birds must surely decrease, and in time the proper equilibrium will be restored. In the meantime, it behooves the farmer to apply such remedies as the exigencies of the case suggest; and, where these gregarious species are overabundant, it might be well to exempt them from the general protective laws, in order that each landholder may be free to protect himself as best he can."

The Bobolink (Dolichonyx oryzivorus) must be studied from two standpoints to obtain a just view of its economic position. With us in the North it is not only the most joyous ornament of our fields, but of definite value to agriculture. During the time it is with us Professor Beal has determined, from the examination of 23 I stomachs, that 57.I per cent of its food consists of animal material, and 42.9 per cent vegetable. "Of the insect food, as determined by the examination, beetles constitute nearly 19 per cent. Predaceous species (Carabidæ), which are, broadly considered, useful insects, are represented only by a trace; snoutbeetles, or weevils (Rhynchophora), amount to 8.9 per cent, and in May to 20.8 per cent; and the other beetles, of various families, and all of a more or less harmful character, make up the rest of the coleopterous food. Hymenoptera, represented by ants and some wasps, and by many parasitic species, form 7.6 per cent of the food, and were found mostly in May and July stomachs. The Bobolink eats more of these parasitic Hymenoptera than any other bird whose food habits have thus 
far been investigated, although it should be stated that examinations of flycatchers and other birds now in course of completion indicate that it will soon lose its position at the head of the list. Caterpillars are apparently a favorite food. They form 17.6 per cent of the May food, and rise to 28. I per cent in June, after which they gradually decrease, averaging in the five months I3 per cent. Those eaten are mostly of the species known as cutworms, and include the well-known Nephelodes violans. Grasshoppers constitute II.5 per cent of the food, and are eaten principally in June and July, when they amount to 23.2 and 25.8 per cent respectively. This is unusual. There seems to be a pretty general law that all birds, no matter what their food habits may be during the rest of the year, eat grasshoppers in August, just as the human race eats certain delicacies in their respective season. But in August, when with most birds the grasshopper season is at its height, the Bobolinks begin to drop their animal diet and eat vegetable food in preparation for the rice season in the South. Besides the insects already mentioned, a few bugs and flies are eaten, and also some spiders and myriapods." (Beal, "Food of Bobolinks, Blackbirds, and Grackles.”)

Of the vegetable matter weed-seeds and rice constitute the largest portion.

In the South the picture is different. "In the last half of April it enters the United States just as the rice is sprouting in southern rice fields, and at once begins to pull up and feed upon the sprouted kernels." "It is estimated that the Bobolinks, with a little help from the Redwings, cause an annual loss of $\$ 2,000,000$ to the rice growers of the South." "Capt. William Miles Hazzard of Hannandale, S. C., says: 'During the nights of August 21st, 22d, 23d, and 24th, millions of these birds make their appearance and settle in the rice fields. From August 2rst to September 25th our every effort is to save the crop. Men, boys, and women are posted with guns and ammunition to every four or five acres, and shoot daily an average of about onequarter of a lb. of gunpowder to the gun. This firing commences at first dawn of day, and is kept up until sunset. After all this expense and trouble our loss of rice per acre seldom falls under five bushels; and, if from any cause there is a check to the crop during its growth which prevents the grain from being hard 
but in a milky condition, the destruction of the rice is complete - not paying to cut and bring out of the field. We have tried every plan to keep these pests off our crop at less expense and manual labor than we now incur, and have been unsuccessful. Our present mode is expensive, imperfect, and thoroughly unsatisfactory, yet it is the best we can do.' Mr. R. Joseph Lowndes, of Annandale, S. C., in writing of the Bobolink and Redwing says: ' I think I am in bounds when I say that one-fourth, if not one-third of the [rice] crop of this river [the Santee] is destroyed by birds from the time the seed is put into the land till the crops are threshed out and put in the barns. I shoot out about roo kegs of powder every September, with a fair quantity of shot, say 30 to 50 bags, and have killed as high as 150 dozen a day. In the bird season it takes every man and boy on the plantation to mind these birds. This work has to go on from daylight till dark in any and all weathers, and at great expense, for six weeks in the fall before the rice is ripe enough for the sickle, and then on till we can get it out of the fields.' These birds, if not carefully minded, will utterly destroy a crop of rice in two or three days.' Mr. A. X. Lucas, of McClellanville, S. C., says: "The annual depredations of the birds are in my opinion equal in this section to the value of the rent of the land - to say nothing of the expense of minding the birds." " Professor Beal concludes, "In the North it does much good and practically no harm; in the South it becomes a veritable pest. To a person born and reared in New England and taught to regard this bird somewhat as the Hollanders regard the stork, it is an unwelcome dity to pronounce upon it a verdict of condemnation; but the facts force the belief that until some practical method shall be devised to prevent its ravages upon the rice crop there can be no other conclusion than that the good done by the Bobolink does not in any appreciable measure counterbalance the harm."

Were the feeding habits alone of the Cowbird (Molothrus ater ater) to be considered in determining its value, it would deserve protection, as Professor Beal finds that "(I) Twenty per cent of the Cowbirds' food consists of insects, which are either harmful or annoying. (2) Sixteen per cent is grain, the consumption of which may be considered a loss, though it is prac- 
tically certain that half of this is waste. (3) More than 50 per cent consists of the seeds of noxious weeds, whose destruction is a positive benefit to the farmer. (4) Fruit is practically not eaten." But, when you remember that for every Cowbird that grows to maturity we lose probably all, or at least a part, of a family of some of our small birds - usually the Red-eyed Vireo, Yellow Warbler, or Oven-bird,- the balance changes. It may be impossible at present to prove that the birds we thus lose are of more value, but all the evidence points that way, and we believe the Cowbird should be killed with as little compunction as the English Sparrow, and its eggs destroyed at every opportunity.

Although the Red-winged Blackbird (Agelaius phoniceus phoniceus) feeds largely on grain during the months of harvest, its service in devouring weed seeds and harmful insects the rest of the year is so great as to turn the balance well in its favor. "The food of the year was found to consist of 73.4 per cent of vegetable matter and 26.6 per cent of animal. The animal food begins with $\mathrm{I} .4$ per cent in January, and gradually increases to 88.2 per cent in June, after which it regularly decreases to a fraction of I per cent in November. With the exception of a few snails and crustaceans, it consists entirely of insects and their allies (spiders and myriapods), so that, roughly speaking, insects constitute one-fourth of the year's food. They consist principally of beetles, grasshoppers, and caterpillars, with a few wasps, ants, flies, bugs, and dragon-flies.

"The beetles (Coleoptera) amount to a little more than Io per cent of the food, and the greater part of them are harmful insects. They belong to several families, but only one group is eaten extensively enough to be greatly distinguished above the others. This is the suborder of snout-beetles, or weevils (Rhynchophora). These constitute 4.I per cent of the year's food, but in June amount to 22.4 per cent of the food of the month. All the beetles of this group are injurious, some of them greatly so."

"Grasshoppers (Orthoptera) are eaten practically in every month of the year, though none were found in the II stomachs taken in January. They constitute 4.7 per cent of the whole food, and are exceeded by no other insects except beetles and caterpillars. The greatest number (amounting to I7 per cent) 
are eaten in August, the 'grasshopper month.' As all species of grasshoppers are injurious, their destruction must be counted to the credit of the bird."

"The vegetable food of the Redwings consists mainly of seeds of grasses and weeds, the different kinds of grain being merely larger or more important grasses. Some of these plants, like wild rice ( $Z_{i z a n i a)}$, have no economic importance; but many others, such as the cultivated grains, are of value, and their destruction is a positive loss; while still others, like ragweed (Ambrosia), are noxious weeds, the destruction of which is a benefit to the farmer." Oats were found to constitute 6.3 per cent of the year's food ; wheat 2.2 per cent ; and corn, 4.6 per cent ; oats are eaten chiefly in July and August; wheat, in July; and corn, in March, August, and September. Much of this grain is taken from the standing crop and must be counted against the bird. "Of the 1,083 stomachs examined, only ro were filled with grain alone, while 217 were entirely filled with the seeds of weeds or useful plants."

"Weed seed is apparently the favorite food of the Redwings, since the total amount of grass and weeds is 54.6 per cent-more than half of the year's food, and more than four times the total grain consumption. These seeds are the principal article of diet of the birds in the Northern States in the early spring and late fall, and the stomachs received from the South during the winter are filled with them almost exclusively. They amount to more than 3 per cent in June, the month of minimum consumption, and constitute a very appreciable percentage even during the months when grain is most abundant. The great bulk consists of the four well-known genera of noxious weeds, Chatochloa (barn grass or foxtail), Ambrosia (ragweed), Panicum (panic-grass), and Polygonum (smartweed and knotweed). The others were found in from I to 64 stomachs each; and, while not all are as much of a nuisance to clean cultivation as the four named, none have any useful function in agriculture. Fruit forms so insignificant a proportion of the Redwing's food that it is hardly worth considering. Blackberries or raspberries were identified by their seed in 7 stomachs, but only a few were found in each, and the percentage is trifling. The other species taken also appear in few stomachs and in small quantities." 
"In summing up the economic status of the Redwing, the principal point to attract attention is the small percentage of grain in the year's food - seemingly so much at variance with the complaints of the bird's destructive habits. Judged by the contents of its stomach alone, the Redwing is most decidedly a useful bird. The service rendered by the destruction of noxious insects and weed seeds far outweighs the damage due to its consumption of grain. The destruction that it sometimes causes must be attributed entirely to its too great abundance in some localities." (Beal, "Food of Bobolinks, Blackbirds, and Grackles.”)

The Rusty Blackbird (Euphagus carolinus) only appears with us in any numbers in the fall after the grain is harvested, and its economic importance is not great. "The stomachs contained a larger proportion of animal matter ( 53 per cent) than those of any other species of American Blackbirds except the Bobolink. This is the more remarkable in view of the fact that none were taken in the two breeding months of June and July, when in all probability the food consists almost exclusively of animal matter. While the birds are decidedly terrestrial in their feeding habits, they do not eat many predaceous ground-beetles (Carabidæ), the total consumption of these insects amounting to only I.7 per cent of the whole food. Scarabæids, the May-beetle family, form 2 per cent, and in April II.7 per cent. Various other families of beetles aggregate Io.I per cent, largely aquatic beetles and their larvæ, which, so far as known, do not have any great economic importance. A few of the destructive snoutbeetles (Rhynchophora) are also included, as well as some chrysomelids and others.

"Caterpillars constitute 2.5 per cent, and do not form any very striking percentage at any time, except, perhaps, in May, when they amount to II.7 per cent. Grasshoppers nearly equal beetles in the extent to which they are eaten, and exceed every other order of insects, although none appeared in the stomachs taken in January, March, May, and December, and in February but a trace. In August, as usual, they reach the maximum, 44.3 per cent, only a trifle higher, however, than the October record. The average for the year is 12 per cent." 
"The vegetable food consists of grain, weed seed, and various miscellaneous substances, none of which amounts to any great percentage. The latter consists chiefly of a very small amount of fruit, a little mast, and a number of unidentifiable substances, probably picked up about water or in swamps. Of grain, corn is the favorite and amounts to I7.6 per cent of the year's food." "The vegetable food is of little consequence, as the birds show no decided predilection for any particular kind, but eat whatever is at hand when animal food cannot be obtained. Grain is not eaten to any great extent at harvest time, and the other items do not seem to have any special relation to the season in which they are eaten." (Beal, "Food of Bobolinks, Blackbirds, and Grackles.")

The Crow Blackbirds or Purple and Bronzed Grackles (Quiscalus quiscula quiscula and ceneus) by their feeding habits present themselves here. "The food of the whole year, taking into account all the 2,346 stomachs, young and adult, comprised 30.3 per cent animal, and 69.7 per cent vegetable matter. The animal food was found to be composed of insects, spiders, myriapods, crayfish, earthworms, sowbugs, hair-snakes, snails, fish, tree-toads, salamanders (newts), lizards, snakes, birds' eggs, and mice.

"Insect food constitutes 27 per cent of the entire food for the year, and is the most interesting part of the birds' diet from an economic point of view."

"Analysis of the insect food presents many points of interest. Among the most important families of beetles are the scarabæids, of which the common June-bug or May-beetle and the rose-bugs are familiar examples. These insects are eaten, either as beetles or grubs, in every month except January and November; in May they constitute more than one-fifth, and in June one-seventh of the entire food. The habit Grackles have of following the plow to gather grubs is a matter of common observation, which has been fully confirmed by stomach examinations. Many stomachs were found literally crammed with grubs, and in many more, where other foods predominated, the hard jaws showed that grubs had formed a goodly portion of a previous meal."

"Next in importance to beetles as an article of blackbird diet are the grasshoppers. For convenience, grasshoppers, locusts 
(green grasshoppers), and crickets are considered in the same category, but of the three the true grasshoppers were by far the most numerous in the stomachs, and are eaten in every month except January. They constitute less than I per cent of the total February food, and the fact that they are found at all in this month indicates that the birds are keen hunters, for it would puzzle an entomologist to find grasshoppers in February in most of the northern states. It is probable that some of those eaten in this and the succeeding month are dead insects left over from the previous year."

"After August the grasshopper diet falls off, but even in November it still constitutes 9 per cent of the total for the month. The frequency with which these insects appear in the stomachs, the great numbers found in single stomachs (often more than 30 ), and the fact that they are fed largely to the young, all point to the conclusion that they are preferred as an article of food, and are eagerly sought at all times. The good that is done by their destruction can hardly be overestimated, particularly as many of the grasshoppers found in the stomachs were females filled with eggs."

"It cannot be doubted from the statements which have been made, that these birds do occasionally destroy the eggs of the robin, bluebird, chipping sparrow, small flycatchers, and other species, and more rarely the young of the robin. But stomach examination offers little corroborative evidence. Of 2,346 stomachs, only 37 contained any trace of birds' eggs, and I contained the bones of a young bird." (Beal, "Food of Bobolinks, Blackbirds, and Grackles.")

"Moreover, the examination of more than 2,000 of their stomachs shows that grain forms 45 per cent of the food of the year, and that corn alone constitutes 35 per cent. From this it might be expected that they would attract much attention from grain growers, and such is the case. Hundreds of communications have been received testifying to their destructiveness; yet many of these acknowledge the fact that blackbirds eat a large quantity of insects, especially during the breeding season, and that many insects are fed to the young. This last is also borne out by stomach examination. A review of the yearly diet shows that the greater part of the corn eaten is taken during the fall 
[Bull.

and winter months. That eaten in winter and early spring (March and April), except the small quantity taken from corn cribs, must be waste grain, or picked up in places where grain is left in the shock for a long time. No one will begrudge the birds the corn gathered from the hog lot or about the cattle crib; but, when they attack the ripening grain in September, it is a different story, and in cases where the birds are so abundant that they take a large part of the crop, it will be difficult to persuade the unfortunate farmer that they did enough good earlier in the season to pay for his loss. There can be little doubt that in many parts of the country these birds are too numerous for the farmer to realize the best results from their services." (Beal, "Birds that Injure Grain.")

The Meadowlark (Sturnella magna magna).- "In the 238 stomachs examined," Professor Beal says, "animal food (practically all insects) constituted 73 per cent of the contents, and vegetable matter 27 per cent. As would naturally be supposed, the insects were ground species, such as beetles, bugs, grasshoppers, and caterpillars, with a few flies, wasps, and spiders. A number of the stomachs were taken from birds that had been killed when the ground was covered with snow, but still they contained a large percentage of insects, showing the bird's skill in finding proper food under adverse circumstances.

"Of the various insects eaten, crickets and grasshoppers are the most important, constituting 29 per cent of the entire year's food and 69 per cent of the food in August. It is scarcely necessary to enlarge upon this point, but it can readily be seen, what an effect a number of these birds must have on a field of grass in the height of the grasshopper season.

"Of the 238 stomachs collected at all seasons of the year, I 78 , or more than two-thirds, contained remains of grasshoppers, and one was filled with fragments of 37 of these insects. This seems to show conclusively that grasshoppers are preferred and are eaten whenever they can be procured. The great number taken in August is especially noticeable. This is essentially the grasshopper month, i. e., the month when grasshoppers reach their maximum abundance; and the stomach examination has shown that a large number of birds resort to this diet in August, no matter what may be the food during the rest of the year. 
"Next to grasshoppers, beetles make up the most important item of the Meadowlark's food, amounting to nearly $2 \mathrm{I}$ per cent, of which about one-third are predaceous ground beetles. The others are all harmful species, and, when it is considered that the bird feeds exclusively on the ground, it seems remarkable that so few useful ground beetles are eaten. Many of them have a disgusting odor, and possibly this may occasionally save them from destruction by birds, especially when other food is abundant. Caterpillars, too, form a very constant element, and in May constitute over 28 per cent of the whole food. May is the month when the dreaded cutworm begins its deadly career, and then the bird does some of its best work. Most of these caterpillars are ground feeders, and are overlooked by birds which habitually frequent trees; but the Meadowlark finds them and devours them by thousands. The remainder of the insect food is made up of a few ants, wasps, and spiders, with a few bugs, including some chinch bugs.

"The vegetable food consists of grain, weed, and other hard seeds. Grain in general amounts to 14 , and weed and other seeds to 12 per cent. The grain, principally corn, is mostly eaten in winter and early spring, and must be therefore simply waste kernels; only a trifle is consumed in summer and autumn, when it is most plentiful. No trace of sprouting grain was discovered. Clover seed was found in only six stomachs, and but little in each. Seeds of weeds, principally ragweed, barn grass, and smartweed, are eaten from November to April, inclusive, but during the rest of the year are replaced by insects.

"Briefly stated, more than half of the Meadowlark's food consists of harmful insects; its vegetable food is composed either of noxious weeds or waste grain, and the remainder is made up of useful beetles or neutral insects and spiders. A strong point in the bird's favor is that, although naturally an insect eater, it is able to subsist on vegetable food, and consequently is not forced to migrate in cold weather any farther than is necessary to find ground free from snow. This explains why it remains for the most part in the United States during winter, and moves northward as soon as the snow disappears from its usual haunts. "There is one danger to which the Meadowlark is exposed. As its flesh is highly esteemed, the bird is often shot for the 
table; but it is entitled to all possible protection, and to slaughter it for game is the least profitable way to utilize a valuable species." (Beal, "Some Common Birds in their Relation to Agriculture.")

The Baltimore Oriole (Icterus galbula) annoys the fruitgrower in August by sometimes puncturing grapes, and is also accused of occasional forays on the cherry trees, or the pea garden. But its services to the farmer and horticulturist far more than pay the toll it takes.

"Observation both in the field and laboratory shows that caterpillars constitute the largest item of its fare. In II3 stomachs they formed 34 per cent of the food, and are eaten in varying quantities during all the months in which the bird remains in this country, although the fewest are eaten in July, when a little fruit is also taken. The other insects consist of beetles, bugs, ants, wasps, grasshoppers, and some spiders. The beetles are principally click beetles, the larvæ of which are among the most destructive insects known; and the bugs include plant and bark lice, both very harmful, but so small and obscure as to be passed over unnoticed by most birds. Ants are eaten mostly in spring, grasshoppers in July and August, and wasps and spiders with considerable regularity throughout the season.

"Vegetable matter amounts to only a little more than I6 per cent of the food during the bird's stay in the United States, so that the possibility of the Oriole doing much damage to crops is very limited. The bird has been accused of eating peas to a considerable extent, but remains of peas were found in only two stomachs. One writer says that it damages grapes, but none were found. In fact a few blackberries and cherries comprised the only cultivated fruit detected in the stomachs, the remainder of the vegetable food being wild fruit and a few miscellaneous seeds." (Beal, " Some Common Birds in their Relation to Agriculture.")

The Orchard Oriole (Icterus spurius) is common only along our southern border, but is a valuable bird. "The food of the Orchard Oriole is almost exclusively insects. Of these it consumes a large number, and with them it also feeds its young. Most of these are of the kinds most obnoxious to the husbandman, preying upon the foliage, destroying the fruit, and otherwise injuring the tree; and their destroyers render an incalculable 
amount of benefit to the gardens they favor with their presence. At the same time they are entirely innocent of injury to crops of any description, and I cannot find that any accusations or expressions of suspicion have been raised against them. They seem to be, therefore, general favorites, and, whenever protected, evince their appreciation of this good will by their familiarity and numbers." (Baird, Brewer, and Ridgway, "North American Birds.”)

FINCHES, SPARROWS, GROSBEAKS, etc.

\section{Fringillide:}

With this family we meet the small birds that throng our woods, fields, gardens, and hedges, and without whose presence it has been calculated agriculture could not continue, as cultivated crops would be either destroyed by insects or choked by a waste of weeds. "In nearly every case where the food habits of our birds have been carefully studied, do we find that the good done far exceeds the possible harm that might be inflicted by our birds. Allowing twenty-five insects per day as an average diet for each individual bird, and estimating that we have about one and onehalf birds to the acre, or in round numbers $75,000,000$ birds in Nebraska, there would be required $1,875,000,000$ insects for each day's rations. Again, estimating the number of insects required to fill a bushel at 120,000 , it would take 15,625 bushels of insects to feed our birds for a single day, or 937,500 bushels for 60 days, or $2,343,750$ bushels for I50 days." (Bruner, Special Bulletin, University of Nebraska, No. 3.)

The Sparrows help chiefly in keeping down the weeds, as the largest part of their food during most of the year consists of the seeds of these pests to the cultivator. "Sparrows are well known and have figured frequently in ornithological literature, but the position they occupy in relation to agriculture has heretofore received only casual consideration. It is evident that a group of birds so abundant, so widely distributed, and in such constant association with farms and gardens must play an important part in rural economy, and that a thorough investigation of their food habits should be useful. The results of such an investigation are embodied in the present paper, and amply demon- 
strate the value of these birds to the agriculturist - a value greater than that of any other group of birds whose economic status has thus far been investigated. The native Sparrows contrast markedly in this respect with the introduced English Sparrow, the pernicious habits of which have formed the subject of a special report, and are briefly treated in this bulletin for purposes of comparison. This naturalized Sparrow is a pest wherever it is found, while the native Sparrows are well worthy of protection and encouragement.

"The great bulk of the food of Sparrows and other small passerine (or perching) birds consists of fruit, seeds, and insects. The fruit may be wild berries taken from shrubs or trees of no economic importance, with little economic result whether the bird eats much or little; or it may be cultivated fruit, in which case, of course, it is desirable to know the amount destroyed.

"The seed element is of particular interest only when it shows destruction of grain and weeds. Injury to grain or fruit by birds is usually the most prominent and often the only fact of economic ornithology possessed by the layman; yet comparatively few birds harm either of these crops, while many species render important service to agriculture by destroying weed seed. As has been aptly said, a weed is a plant out of place. Certain plants seem to have formed a habit of constantly getting out of place and installing themselves in cultivated ground, but whether actually among crops or in adjacent waste land, from which they can spread to cultivated soil, they are always a menace. In the garden they occupy the room allotted to useful plants, and appropriate their light, water, and food. Any check on these noxious interlopers, a million of which can spring up on a single acre, will not only lessen nature's chance of populating the soil with worse than useless species, but will enable the farmer to attain greater success with cultivated crops. The hoe and cultivator will do much to eradicate them, but some will always succeed in ripening a multitude of seeds to sprout the following season. Certain garden weeds produce an incredible number of seeds. A single plant of one of these species, as purslane, for instance, may mature as many as 100,000 seeds in a season, and these, if unchecked, would produce in a few years a number of weeds utterly beyond comprehension. The habits of some of the 
common weeds are considered in connection with the discussion of the value of birds as weed destroyers.

"The animal food of the smaller land birds consists of insects and spiders. The insects belong for the most part to the orders Lepidoptera (butterflies and moths), Orthoptera (grasshoppers locusts, and crickets), Diptera (flies), Hemiptera (bugs), Coleoptera (beetles), and Hymenoptera (ants, bees, and wasps). Lepidoptera, Orthoptera, and Coleoptera furnish the bulk of the insect food of birds. The lepidopterous food is taken almost entirely in the larval condition, and comprises smooth caterpillars belonging largely to the family Noctuidæ, which includes cutworms, army worms, and their allies. The Orthoptera eaten are principally long- and short-horned grasshoppers (Locustidæ and Acrididæ). Coleoptera form a most important element of bird food, the families of this order most largely represented being the Scarabæidæ or scarabæid beetles, the Carabidæ or ground beetles, the Elateridæ or click beetles, the Chrysomelidæ or leaf beetles, and the Rhynchophora or weevils. Some of the scarabæids that are eaten are the clumsy brown May beetles and their allies which feed on growing plants; others comprise a group of beetles commonly known as dung beetles, because they subsist on the droppings of animals. Ground beetles are alert, active insects, carnivorous in food habits. Click beetles are narrow and hard-shelled; when disturbed, they curl up and 'play possum ' until the danger appears to be past, when they spring into the air by spasmodically straightening out their bodies with a sharp clicking sound. Their larvæ, wireworms, are often very destructive to crops. The leaf beetles taken by birds are pests of little economic importance. Weevils constitute a destructive class of insect pests, and are extensively preyed on. Diptera furnish no significant part of the food of birds, though the slow-moving crane-flies (Tipulidæ) and midges (Chironomidæ) are at times snapped up, and some larval Diptera are occasionally eaten. The Hemiptera include both leaf-hoppers (Jassidæ), which derive their sustenance by probing plants with their sucking beaks; and true bugs, which are flat, bad-smelling insects. Some of the bugs feed like leaf-hoppers on the juices of plants, while others are predatory and subsist on succulent insects. The hymenopterous element of bird food is composed of ants, wasps, and a 
few small bees, the wasps including flower-fertilizing species and parasitic species of the families Ichneumonidæ, Braconidæ, and Scoliidæ.

"The value of a bird as an insect destroyer depends upon the yalue of the insects it consumes. Each insect eaten by birds must of necessity be injurious, beneficial, or neutral in its effect on crops, though it is not always easy to classify it properly. While present information is sufficient to fix the status of some with sufficient accuracy for all practical purposes, in the case of others more light is needed. The smaller dung-feeding scarabæid beetles appear to have little or no effect upon agriculture. The great majority of ants have habits which are apparently of little interest to the agriculturist; and although some (of the genus Lasius), and perhaps others, possess certain injurious traits, while a few may have traits that are beneficial, yet the effects in any event are of minor importance; so that ants as a whole may safely be classed as neutral. Spiders, which for purposes of convenience are here classed with insects, are carnivorous, but their prey seems to include about as many beneficial insects as pests. The damage done by weevils, grasshoppers, and smooth caterpillars is notorious. Cutworms and army worms often do an immense amount of harm, and grasshoppers frequently occur in such voracious hosts that they sweep away every vestige of green vegetation before them. On the other hand, carnivorous ground beetles (Carabidæ) kill multitudes of insect pests, and certain parasitic wasp-like hymenopterous insects of the families Braconidæ, Chalcididæ, and Ichneumonidæ destroy great numbers of caterpillars. One of these parasitic insects will deposit in the back of a caterpillar from 20 to 2,000 eggs, which soon hatch into grub-like larvæ that feed upon the fatty tissues and exhaust the caterpillar so that it is not able to transform into a perfect insect."

"On one of the Maryland farms visited in 1896, Tree Sparrows, Fox Sparrows, White-throated Sparrows, Song Sparrows, and Juncos fairly swarmed during the month of December in the briers of the ditches between the cornfields. They came into the open fields to feed on weed seed, and were most active where the smartweed formed a tangle on low ground. Later in the season the place was carefully examined. In a cornfield near a 
ditch the smartweed formed a thicket more than 3 feet high, and the ground beneath was literally black with seeds. Examination showed that these seeds had been cracked open and the meat removed. In a rectangular space of 18 square inches were found I,I3O half seeds and only 2 whole seeds. During the ensuing season no smartweed grew where the sparrows had caused this extensive destruction. Even as late as May I3 the birds were still feeding on the seeds of these and other weeds in the field. Sixteen sparrows were collected on that date, and 12 of these, mainly Song, Chipping, and Field Sparrows, proved to have been eating old weed seed. So thoroughly had the work been done that diligent search showed only half a dozen seeds in the field where they had been feeding. The birds had taken practically all that were not covered; in fact, the Song Sparrow and several others had scratched up much buried seed."

"It is hardly to be expected that such seed eaters as sparrows should destroy as great a quantity of insect pests as birds that are entirely insectivorous. When it is found that in the food of the native sparrows such pests average but 25 per cent, it is only what might be expected. Still this percentage, when compared with the percentage found in the cases of some birds, is no mean showing. The Red-winged Blackbird's is less than 20 per cent, the Catbird's but 16 per cent, the Cowbird's less than 20 per cent, and the Crow Blackbird's only Io per cent.

"But as weed destroyers, the native sparrows are unrivaled. In a garden within two months they will sometimes destroy 90 per cent of such weeds as pigeon-grass and ragweed. After they have consumed most of these seeds they turn to those of other weeds, which furnish them with a bountiful supply of food all through the winter and even well into the spring. Weed seed forms more than half of their food for the entire year, and during the colder half of the year it constitutes about four-fifths of the food of many species."

"Part of the investigation on this farm was directed to the question of the dissemination of weed seed by sparrows. One hundred and fifty bird droppings were collected on each side of the brook, in the ragweed field and in the weedy garden above. Examination of these revealed but seven uninjured seeds, one of crab-grass and six of amaranth, certainly a very insignificant 
proportion of the number consumed. And it is not unlikely that many of those thus voided uninjured are afterwards taken a second time. Most of the dung consisted of the pulverized remains of seeds, among which the most conspicuous were small fragments of the akenes of ragweed." (Judd, "The Relation of Sparrows to Agriculture.”)

We shall make no attempt to discuss the food of all the 34 members of this family that occur more or less regularly in our state, as the space required would be too great and nearly the same feeding habits characterize all, but confine ourselves to some of the more important or noticeable species.

The Pine Grosbeak (Pinicola enucleator leucura) occasionally visits us in flocks in winter. They "travel in small flocks, which spend much of their time in coniferous forests, feeding upon buds of pine and spruce; they also eat the buds and seeds of white ash, basswood, alder, birch, apple, pear, and poplar, as well as the berries of the red cedar and the high-bush cranberry. In winter they often subsist largely upon the pulp and seeds of frozen apples. In some instances they have been known to injure fruit orchards by feeding upon the buds, but this is a rare occurrence. Professor Aughey found that five Nebraska specimens taken during winter had eaten, along with various seeds, a large number of eggs of the Rocky Mountain locust." (Weed and Dearborn, "Birds in their Relation to Man.")

The Purple Finch (Carpodacus purpureus purpureus) has been seen, " feeding on the seeds of the poplar, buttonwood, juniper, cedar, and on those of many rank weeds that flourish in rich bottoms and along the margins of creeks. When the rainy season is very severe, they proceed to the South, as far at least as Georgia, returning North early in April. They now frequent the elm trees, feeding on the slender but sweet covering of the flowers; and as soon as the cherries put out their blossoms they feed almost exclusively upon the stamens of the flowers; afterwards the apple blossoms are attacked in the same manner; and their depredations on these continue until they disappear, which is usually about the tenth or middle of May.' Many later observers have seen the Purple Finch eating the tender portions, although little real damage seems to be done by it; and as a partial offset it is also known to devour aphides and various 
caterpillars." (Weed and Dearborn, "Birds in their Relation to Man.”) This bird also often destroys the seeds of noxious plants, as the ragweed.

The American and White-winged Crossbills (Loxia curvirostra minor and leucoptera) feed chiefly on the seeds of pines, hemlocks, and spruces. None of the above species, however, have been shown to do any real harm, and none are usually common with us.

With the English Sparrow (Passer domesticus domesticus) the case is different. Thronging in our cities and crowding yearly farther into the country districts, multiplying with enormous rapidity and driving our small native birds before it, this once welcome foreigner has turned its warm reception into active dislike. But all attempts to exterminate it by bounty or combined effort have so far been failures, and the best that can be hoped for is to protect our native birds against its attacks and destroy it when possible. At first only an inhabitant of cities in this country, this sparrow readily adjusts itself to surroundings and climate, and the writer has seen it in flocks of hundreds far from towns in the interior of North Dakota. "The English Sparrow, or, more properly speaking, the house sparrow of Europe and Asia, was introduced into the United States about 1850, and has increased and spread until now it is one of the most abundant birds east of the Mississippi River. It does not, however, occur in the lower part of Florida and certain parts of Mississippi and Louisiana, nor in some portions of Maine, Minnesota, and North Dakota. West of the Mississippi River its range forms a tonguelike area extending to the base of the Rocky Mountains in Colorado, and includes Missouri, Kansas, Arkansas, Indian Territory, and parts of South Dakota, Texas, Oklahoma, and Nebraska. It is also found in isolated localities west of the Rocky Mountains, principally about the Great Salt Lake, San Francisco Bay, near Portland, Oregon, and on Puget Sound, Washington. In Canada it is established to a greater or lesser degree in all the eastern provinces. It has recently penetrated to Manitoba, but has not yet otherwise secured a foothold to the north and west of Ontario. Throughout its range it abounds chiefly in towns and villages, along roads, and about farms, and is not found in mountainous or forested districts. 
"The relation of the bird to man was investigated by the Department of Agriculture, and the results were published in 1889. This investigation, which included extended field observation and the examination of more than 600 stomachs, showed the species to be a serious pest. Since the appearance of this publication 132 additional stomachs have been examined, and a special study has been made of the food of the young. For the latter purposes 50 birds from 3 days to 3 weeks old were collected during the last of June and the first of July, I899, from a farming region in Virginia opposite Washington, D. C.

"The 82 stomachs of adults were collected throughout the year in rural localities in Maryland, Michigan, New York, Pennsylvania, Ohio, Indiana, and Kansas. Animal matter, practically all insects, constitutes 2 per cent of the food, and vegetable matter, almost entirely seeds, 98 per cent. Insects were taken chiefly during May and June, when they composed to and 8 per cent respectively of the month's food. Of the 98 per cent constituting the vegetable food, 7 per cent consisted of grass seed, largely of plants of the genera Zizania (wild rice), Panicum, and Chctochloa, and notably crab-grass and pigeon-grass, and I7 per cent of various weeds not belonging to the grass family. The grass and weed seeds taken are not noticeably different from those usually eaten by native sparrows. But what especially differentiates the vegetable food from that of all other sparrows is the large proportion of grain consumed, which formed 74 per cent of the entire food of the year and 90 per cent of that of the period from June to August.

"The examination of the contents of the stomachs of the 50 nestlings made an unfavorable showing for the species. It was found that, instead of being exclusively insectivorous, like the young of all the native sparrows so far as known, the young English Sparrows had taken 35 per cent vegetable food, 2 per cent being weed seed and 33 per cent grain. The animal food was made up entirely of insects and those were chiefly injurious. One per cent of the food consisted of bugs; 3 per cent of ants and other Hymenoptera, 4 per cent of Lepidoptera, 8 per cent of beetles, and 49 per cent of grasshoppers.

"Three-fourths of the beetles were weevils, and practically all the grasshoppers were the short-horned (Acrididæ), the 
greater part of which belonged to the species Melanoplus atlanis and Melanoplus femur-rubrum. The destruction of these harmful insects is of course a service to agriculture; but it must be remembered that all the food of the nestlings of other sparrows consists of insects just as injurious, while one-third of the food of English Sparrows is composed of grain.

"As an insect destroyer the English Sparrow does its best service by destroying grasshoppers, principally in feeding nestlings, nearly half of the food of which, as shown, was found to consist of grasshoppers of the genus Melanoplus. Other Orthoptera are eaten to a slight extent. It is a common sight along roads to see the birds pursuing and capturing the large dust-colored grasshopper (Dissosteira carolina) which shows yellow underwings when it flies. Long-horned grasshoppers (Locustidæ), small grasshoppers of the genus Tettix, and, in one instance at least, the mole cricket (Gryllotalpa) were included in the orthopterous food found in their stomachs. The species of Lepidoptera preyed on are important pests. Whenever there is an uprising of army worms, the English Sparrows feast on the abundant supply. They have been observed catching the moth also of the army worm. During spring and early summer, they remove many cutworms from lawns, and, to a certain extent, feed on hairless caterpillars on shade trees. Occasionally they destroy a few hairy caterpillars; they eat the fall webworm and tussock-moth caterpillars; and sometimes feed on the moths and egg clusters of the latter species; they are included by Forbush among birds seen to feed on the gypsy moth, and they have been observed by Weed preying on the moths of the forest tent caterpillar. But that they do not habitually eat hairy caterpillars and should not be expected to act as a potent check upon such insects, is evidenced by the fact that only two of nearly 700 stomachs examined contained hairy caterpillars."

"It appears, therefore, that there is little to be said in favor of the English Sparrow. Its insectivorous habits are creditable as far as they go, but they are insignificant because the diet is almost exclusively vegetable; and, while it is in the vegetable fare that the value of most sparrows consists, yet in the case of the English Sparrow the damage to grain far overbalances the benefit of weed seed destruction. Adding to this the injury it 
causes to buildings and statues in cities, there is no escape from the conclusion that the bird is a serious pest, the extermination of which would be an unmixed blessing." (Judd, "The Relation of Sparrows to Agriculture.")

As will be seen from these statistics, almost the entire food of this bird is vegetable food and this is taken chiefly from growing crops. It is known to inflict serious injury on grain, including rye, wheat, barley, rice, oats, and corn; green vegetables, including peas, cabbages, and tender shoots; fruits and berries, such as pears, apples, peaches, grapes, figs, cherries, and currants ; and on buds, blossoms, and foliage of all sorts. Not content with this it attacks our native birds, preempts the breeding places of some, and enters the homes of Martins, Swallows, Bluebirds, and Wrens, destroys their eggs or young, and rears its own brood in their place. Professor Barrows gives a list of 75 species of our native birds which English Sparrows have been reported to molest, among which are 377 different records of their attacking the Bluebird, 182 on the Robin, r9I on different Wrens, 440 on Swallows and Martins, and 273 on other Sparrows. That its habits have not improved in recent years, an investigation made by Mr. Charles K. Reed in I904 shows. Of over Ioo postals and many letters received regarding this bird only four were in its favor. ("American Ornithology," Vol. 4, p. I30.)

Still another count in the grave indictment against this species has been proven by Mr. H. E. Ewing in The Auk for July, I9II ; and he reaches the following conclusions: "The English Sparrow frequently harbors and is the host of one of our worst, if not the worst, of poultry pests, the chicken louse or chicken mite, Dermanyssus gallince Redi. Sparrows become repeatedly inoculated with these mites from the chicken roosts, because of their habit of lining their nests with poultry feathers, many of which have lice upon them, shaken off of the infested chickens when wallowing in the dust, etc. Sparrow nests, when built in the vicinity of chicken roosts, upon becoming deserted may leave hundreds or thousands of lice, to seek food and shelter elsewhere. These individuals being very active on their feet, and able to sustain themselves for several days away from a host, may travel distances and infest new chicken houses. 
"The English Sparrow likewise harbors and is the host of perhaps the most important of all external parasites of our native song birds, and likewise of our tamed cage birds, the bird mite, Dermanyssus avium De Geer."

The English Sparrow multiplies so rapidly (having been known to raise six broods in a year) that our native birds could not compete with it were they equally pugnacious and capable like it of remaining in this region all the year. "It is a hardy, prolific, and aggressive bird, possessed of much intelligence and more than ordinary cunning. It is domestic and gregarious in habit, and takes advantage of the protection afforded by proximity to man, thus escaping nearly all the enemies which check the increase of our native birds. Moreover, for many years it was looked upon with favor, and both food and shelter were provided for it.

"Its fecundity is amazing; and, from the testimony submitted, it is evident that it is no unusual thing for a single pair, in the latitude of New York or further south, to rear twenty or thirty young in the course of a year. Assuming the annual product of a pair to be twenty-four young, of which half are females and half males, and assuming further, for the sake of computation, that all live, together with their offspring, it will be seen that in ten years the progeny of a single pair would be $275,716,983$, 698." (Barrows, "English Sparrow in North America.")

With such a record, the only question left is what measures can best be taken against it. "In the city of Boston, during I899, a crusade was inaugurated through the efforts of the American Society of Bird Restorers. From March I3 to April 5, six men were employed in the Common and Public Garden destroying the nests and eggs. Five thousand nesting holes were plugged up, 4,000 nests destroyed, and I,000 eggs broken, but no birds were killed. It is claimed that nearly half of the sparrows which normally breed on the Common and Public Garden were driven away. In May only 250 to 300 pairs of sparrows were found, while the number of pairs counted in the parks before the sparrow war began amounted to 500 .

"Much is always to be learned from an experiment of this kind, and other cities should profit by Boston's experience. There is reason to believe, however, that the present rapid supplanting 
of horse power by electricity will, by reducing the food supply of the birds, do more toward diminishing their numbers in the city parks than any plan for restricting their reproduction. The amount of expense that may profitably be incurred in combating the sparrow will depend on circumstances, as in the case of the house rat and mouse; but it should be borne in mind that the bounty system has proved to be only an extravagant failure." (Judd, "The Relation of Sparrows to Agriculture.")

But to effectually combat these pests more active measures must be taken. "Preliminary to the following destructive meas- . ures, sparrows should be baited until they are attached to the spot selected for their execution. Seeds, grain, or waste from the table, if supplied regularly, will soon establish a feeding place. If a general campaign is to be undertaken, enough such feeding places should be maintained to attract to them practically all the English Sparrows in the neighborhood. This can be easily done in winter when food is scarce. After thus baiting the sparrows they may be trapped, shot, or poisoned.

"Traps alone are inadequate to exterminate sparrows, but a reduction of numbers can be effected by using a shallow box not less than 4 feet square, open on one side and covered with woven wire on the other. One side of this trap rests on the ground, while the opposite side is supported by a stick 18 inches long. Near the upper end of this stick is attached a long cord, and between the top of it and the edge of the trap is placed a chip. By setting the trap over bait and pulling the cord from a sheltered place of observation when a flock of sparrows is beneath it, numbers of them may be caught. Instead of the box described above, by which the birds are taken alive, an old door or similar device may be employed as a deadfall. In either case the trap should be kept set and baited until the sparrows are not afraid to go under it. The best time for trapping is just after a snowstorm, when the birds have been fasting. Then, if the ground be cleared and chaff and grain be put under the trap, the birds will crowd in and enable the trapper to secure nearly all of the local flock. If any escape, they will spread the fear of traps, and before long very few of the birds can be induced to go into one. 
"Sparrows are accustomed to feed in close flocks, and when thus assembled a large number can be killed by a charge of No. Io shot. The best way is to scatter grain over long, narrow areas and shoot the sparrows at these baiting places. Where sparrows infest poultry yards, the bait may be placed on a horizontal board, supported at such an elevation that the birds can be shot without danger to the poultry.

"Since English Sparrows are a pest, and a reduction of their numbers is important on economic grounds, there would seem to be no reason why the birds, when trapped or shot, should not be utilized for food in this country, as they have been in the Old World for centuries. Their flesh is palatable and nutritious, and in city restaurants they are often served under the name of reedbirds.

"Where the use of poison is not prohibited by law, it may be effectively used to reduce the number of sparrows. Of the different poisons tested, the most satisfactory is strychnia sulphate. It is easily prepared and acts quickly. Wheat has proved to be a good bait, as well as an excellent vehicle for administering the poison. The grain should be regularly supplied at the baiting stations until the birds have become accustomed to resort to the place. A good time to put it out is early morning, as the birds are sure to be hungry for breakfast. The capacity of the sparrow's crop and stomach is about 30 kernels of wheat, varying according to the size of the kernels. In deciding the amount of poisoned wheat to put out at one time, it is well to estimate the number of sparrows frequenting a feeding place and to allow about 20 kernels for each sparrow.

"Although two kernels of wheat coated with the solution described below have been known to kill a sparrow, 6 or 7 kernels are required to insure fatal results. Only as much poison should be put out as is likely to be eaten in one day, as exposure to moisture reduces its virulence. Furthermore, sparrows that take less than a fatal quantity, or that become frightened by the death of comrades, will forsake a feeding place if poison is kept there constantly. It is better, therefore, to supply unpoisoned wheat after each poisoning until the birds have recovered confidence. An important advantage in having several feeding grounds is that they may be used in rotation, the sparrows for- 
getting their fear of one while the others in turn are receiving poison.

"A poison mixture that has proved very effective is prepared as follows: Put one-eighth ounce of strychnia sulphate into three-fourths of a gill of hot water, and boil until dissolved. Moisten I $\mathrm{I} / 2$ teaspoonfuls of starch with a few drops of cold water, add it to the poison solution, and beat till the starch thickens. Pour the hot poisoned starch solution over I quart of wheat, and stir until every kernel is coated. Small-kerneled wheat sold as poultry food, if reasonably clean, is preferable to first-quality grain, being cheaper and more easily eaten by the sparrows. A 2-quart glass fruit jar is a good vessel to mix in, as it is easily shaken and allows the contents to be seen. If the coated wheat be spread thinly on a hard, flat surface, it will dry enough for use in a short time. It should be dried thoroughly if it is to be put into jars and kept for future use. Dishes employed in preparing poison may be safely cleansed by washing.

"The poison should be well scattered, so that many birds may be able to partake at the same time, since after a few are affected their actions excite the suspicion of their comrades. Usually a few sparrows get only enough strychnine to paralyze them for a few hours, after which they recover. It is important, therefore, to visit the feeding places two or three hours after distributing poison, to prevent such birds from escaping. It is well also to remove dead birds promptly to avoid exciting the suspicions of those that are unaffected. In northern latitudes the best time to put out poison is just after a snowstorm, when other food is covered. The feeding place should be cleared of snow and the poison laid early in the morning.

"Sparrows should be baited in secluded places, safe from interruptions, and where doves and poultry are not endangered. Roofs, back yards, and unused poultry runs are favorable situations. Proximity to low trees, grape arbors, and similar retreats, has the advantage that sparrows go to such places between meals, and many dead birds will be found there well away from the bait. If undisturbed, poisoned birds will usually be found within a few feet of where the bait was spread, death occurring in from three to twenty minutes. Where doves or poultry are likely to be poisoned, the sparrows, after being baited, may be induced 
to feed in small covered pens made of coarsely meshed wire netting and having the sides raised about an inch and a half above the ground. There is practically no danger that cats or other animals will die from eating sparrows that have been poisoned. Any wheat coated by the above process, which is overlooked by the birds, will become harmless after a few-rains. Sparrows can be reduced locally to almost any desired extent by the methods outlined above, but it should not be forgotten that such reduction can be made permanent only by systematic and continued efforts." (N. Dearborn, "How to Destroy the English Sparrow.")

With this species our review of harmful and negative sparrows ceases, for almost all the remaining species are exceedingly useful.

The American Goldfinch (Astragalinus tristis tristis) "or wild canary, is as useful as it is beautiful, and as a weed destroyer has few equals. It confines its attention very largely to one family of plants, the Compositæ, and is especially fond of thistles, wild lettuce, wild sunflower, and ragweed. It is so often seen on thistles, both Canada and bull thistles, that it is commonly known as the thistle bird. Near Washington, D. C., a flock of a dozen birds was seen during the latter part of August feeding on sunflowers that had escaped from cultivation, and in the central and western states the Goldfinches do much good by eating the seeds of wild sunflowers and other closely related weeds. They have also been seen feeding upon wild lettuce (Lactuca spicata), and probably eat prickly lettuce (Lactuca scariola), which has proved the most rapidly spreading weed ever introduced into this country; but as yet no actual observations as to the latter food habit have been made. Stomachs collected in August were filled with seeds of Compositæ, mostly sunflowers (various species of Helianthus) and thistles (Carduus lanceolatus and other species.)

"At Burlington, Iowa, during July and August, Mr. Paul Bartsch found Goldfinches feeding exclusively upon the bull thistle (Carduus lanceolatus). He was able to approach within a few feet of several birds while thus engaged, and noticed that the seeds or akenes were bitten off and swallowed while the plumes or pappus floated away. When there was no wind, the 
pappus often failed to fly away, and clung to the birds, almost burying them with down. A dozen of the birds were killed, and their gizzards and gullets were found literally crammed with the thistle seed. At Sing Sing, N. Y., Goldfinches have been seen eating the seed of the Scotch thistle (Onopordon acanthium) and boneset (Eupatorium perfoliatum). Coneflowers (Rudbeckia hirta), prairie sunflowers (Caillardia), evening primroses, catnip, elephant's-foot (Elephantopus sp.), and mullein also form part of their food; and late in the season they turn their attention to ragweed, and consume great quantities of the seeds of this troublesome species. In winter and spring large flocks feed to some extent upon the seeds of conifers and catkin-bearing trees, such as the sycamore and birch. In destroying the seeds of the gray birch (Betula populifolia) on the edge of grass lands they do some good, for this tree has a habit of seeding adjacent pastures, which then grow up into a thicket of young saplings." (Judd, "Birds as Weed Destroyers.")

The Pine Siskin (Spinus pinus) and the Redpoll (Acanthis linaria) "feed largely upon seeds of conifers, sycamores, birches, and alders, but also descend to the ground to eat weed seed. In winter they feed upon sow thistles (Sonchus oleraceus), field asters (Aster sp.), and goldenrod (Solidago sp.). The Redpoll Linnet is known to destroy mullein seeds (Verbascum thapsus), and the Pine Siskin is often seen consuming quantities of seeds of chickweed (Alsine media), lamb's-quarters (Chenopodium album), and ragweed (Ambrosia artemisicfolia)." (Judd, "Birds as Weed Destroyers.")

The Snowflake or Snow Bunting (Plectrophenax nivalis nivalis), coming in winter to our snow-covered fields, feeds on the seeds clinging to the weed stalks that stand above the drifts. "From the examination of the stomachs collected, it would appear that the Snowflake derives fully half its subsistence from two weeds - amaranth and ragweed; and that it does not to any great extent feed on the seeds of crab-grass, pigeon-grass, or other grasses, though it should be stated that McIlwraith reports it as eating the seeds of broom sedge (Andropogon scoparius). Only I per cent of the food contained in the 46 stomachs examined was grass seed. But, in addition to the fact that the number of stomachs examined was too small to permit final conclusions 
to be drawn, for other reasons this should not be taken as showing a distaste for grass seed. The taste for similar food, as shown by the partiality of the birds for grain, and the quantity of grass seed eaten by the closely allied, more southerly ranging Long-spurs, indicate that the abstinence of the Snowflake from this food is due to necessity and not choice. We must remember that the grass seed, which falls to the ground when ripe, instead of clinging to the stalk, as do many of the seeds of amaranth, lamb's-quarters, and ragweed, is probably buried under the snow during most of the time the Snowflakes are here. The amaranth is tall, and its seeds are particularly clinging, and after very heavy snowfalls it is probably the most available food supply the Snowflakes have. Its seeds form half the food found in the stomachs collected in February and March, some of which contained from 500 to 1,500 each. Such a wholesale destruction of the seeds of this rank weed as is thus indicated is not accomplished by any other bird whose food habits have thus far been investigated. With most species of seed-eating birds amaranth is by no means an important article of diet.

"On account of its good work as a weed destroyer and the apparent absence of any noticeably detrimental food habits, the Snowflake seems to deserve high commendation, and should receive careful protection. Feeding in latitudes that have been deserted by most other weed-destroying birds, these birds render a distinct and most effective service to the northern farmer." (Judd, "The Relation of Sparrows to Agriculture.")

The Vesper Sparrow (Pocetes gramineus gramineus), a steadily decreasing summer resident of our hayfields, lives chiefly on different injurious insects while it is with us, the animal proportion of its food reaching 90 per cent in the height of summer. Beetles and grasshoppers are most sought after, and next to them come "cutworms, army worms, and other smooth caterpillars that infest upland grass lands." "Its value to the farmer is beyond question and should secure for it the fullest protection." (Judd, "The Relation of Sparrows to Agriculture.")

Regarding the Savanna Sparrow (Passerculus sandwichensis savanna), Dr. Judd finds from the examination of II9 stomachs that, "Their food contents consisted of 46 per cent of animal matter, insects and their allies, and 54 per cent of vegeta- 
ble matter, practically all seeds. The Savanna, Ipswich, and Grasshopper Sparrows, and, to a slighter degree, all other members of the genus Ammodramus, are much more highly insectivorous than other sparrows. They take equal rank in this regard with such notable insect destroyers as the Catbird, Robin, and Bluebird. With the Savanna Sparrow the distribution of animal matter is as follows: Coleoptera, 15 per cent; Lepidoptera, 9 per cent; Orthoptera, 8 per cent; Hymenoptera, 5 per cent; Hemiptera, 2 per cent; Diptera and miscellaneous insects, 4 per cent; and spiders, with a few snails, 3 per cent.

"This sparrow appears to be the greatest eater of beetles of all the sparrow family. Beetles constitute the most important element of its animal food, and are eaten during every month in which stomachs were obtained, though, of course, in very small quantities during the winter months."

"The character of the vegetable food shows the Savanna Sparrow to be a great consumer of grass seeds. It is not harmful to grainfields, however, as the grain taken amounts to only about I per cent of the food, and this consists almost entirely of waste wheat and oats. During August, a month in which birds exhibit a great liking for a cereal diet, a number of Savanna Sparrows were collected from oat and barley fields, but their stomachs contained nothing but insects. Grass seed, largely pigeon-grass (Chetochloa) and panic-grass (Panicum), amounts to $3^{I}$ per cent of the food. Other seeds, mainly such weed seeds as are taken by the Vesper Sparrow, make up practically all of the remaining 22 per cent of the vegetable matter, the only exception being a few blueberries found in one of the stomachs.

"It appears from this examination that the Savanna Sparrow is an exceedingly valuable bird. During the winter, when it is most granivorous, more than half of its food consists of weed seeds; and from May to August, when it is most insectivorous, beneficial insects form only 3 per cent of the food, while insects of the injurious class amount to 45 per cent." (Judd, "The Relation of Sparrows to Agriculture.")

About the Grasshopper Sparrow (Ammodramus savannarum australis) Dr. Judd writes, "The Grasshopper Sparrow received its name because of the character of its song, which closely resembles the stridulation of the long-horned grasshopper; but 
investigation of its food habits has shown that, by a curious coincidence, the name is fully as appropriate in consideration of its diet. Grasshoppers (Acrididæ and Locustidæ) form almost onefourth ( 23 per cent) of the food of the eight months in which the I 70 stomachs examined were collected, and 60 per cent of the food in June, in which the greatest quantity of these destructive insects is eaten. The genera Xiphidium, Scudderia, Hippiscus, and Melanoplus are best represented.

"Among the sparrows of the farm seven are preeminently grasshopper destroyers - the Dickcissel, and the Grasshopper, Lark, Vesper, Chipping, Song, and Field Sparrows;- and from May to August, inclusive, the insect-eating period, consume large quantities of these pests. The examination of stomachs collected during this period shows that grasshoppers form $4 \mathrm{I}$ per cent of the food of the Dickcissel, 37 per cent of that of the Grasshopper Sparrow, 3I per cent of that of the Lark Sparrow, 23 per cent of that of the Vesper Sparrow, 2 I per cent of that of the Chipping Sparrow, I7 per cent of that of the Song Sparrow, and I3 per cent of that of the Field Sparrow."

"The vegetable food of the Grasshopper Sparrow is of little importance when compared with that of other species. No fruit was found excepting a few blueberries in one of the stomachs; and grain, chiefly waste, forms only 2 per cent of the food. Of the seeds, wood sorrel ( $O x$ alis) composes 2 per cent of the food; ragweed, 5 per cent; such grasses as pigeon-grass, panic-grass, and a few others less freely eaten, I7 per cent; and various other plants - polygonums, purslane, rib-grass, and the sedges - II per cent. The entire weed seed element, including the seeds of such grasses as are troublesome on the farm ( 7 per cent of the total food), amounts to about one-fourth of the food.

"The Grasshopper Sparrow in particular, and the other species of the genus Ammodramus in general, feed much less on vegetable matter than most other sparrows. Insects form their staple diet, and of these, beetles, grasshoppers, and caterpillars are the most important. As a destroyer of insect pests the Grasshopper Sparrow is most efficient. It is not only superior to other members of the same genus, but is even more efficient than such valuable species as the Lark Sparrow, Vesper Sparrow, and Dickcissel; and, both its vegetable and animal food considered, it 
seems to be individually the most useful species of bird whose food habits have thus far been investigated. The injurious part of the food forms only 3 per cent of the whole, while the neutral amounts to 24 per cent, and the beneficial to 73 per cent." (Judd, "The Relation of Sparrows to Agriculture.")

The Sharp-tailed and Seaside Sparrows (Passerherbulus caudacutus and maritimus maritimus), inhabiting our salt marshes exclusively, have little effect on agriculture except as they destroy the insect enemies of the salt hay. "The examination of $8 \mathrm{I}$ stomachs of both species indicates that 2 per cent of the food consists of insects which probably exert a beneficial influence on the salt hay crop, 30 per cent consists of insects which are perhaps injurious to it, and ro per cent consists of spiders, concerning whose relation to it there is much doubt. The remaining 58 per cent of the food is made up of approximately equal parts of insects and seeds of plants having little, if any, relation to the hay crop. The birds do not prey on the salt-marsh caterpillars, so destructive to the hay, and they destroy a considerable amount of the seed of the marsh grasses, which is probably an injurious effect. Thus, investigation shows that the two species are apparently of little economic importance." (Judd, "The Relation of Sparrows to Agriculture.")

Of the White-throated Sparrow (Zonotrichia albicollis), found in flocks along our hedge-rows in fall, Dr. Judd speaks as follows: "Two hundred and seventeen stomachs, collected during every month in the year except June, have been examined. Most of these stomachs were collected in New York and Pennsylvania, but a large number came from Iowa, Minnesota, Georgia, and Texas, and some from New Brunswick. The food for the year, as a whole, as indicated by stomach contents, consists of 19 per cent animal matter and 8I per cent vegetable matter. Of the vegetable food 3 per cent is grain, 50 per cent weed seed, and the remainder chiefly wild fruit.

"The insect food resembles that of many other species in general character, but some interesting differences appear when it is viewed in detail. Hymenoptera constitute 6 per cent of the year's food; Coleoptera, 5 per cent; Heteroptera and Diptera, taken together, 3 per cent; and Lepidoptera, 3 per cent; the customary quota of spiders, millipedes, and snails supplying the remaining 2 per cent of animal food." 
" Some grass seed is consumed, principally seeds of such troublesome species as pigeon-grass, crab-grass and other panicums, and Johnson grass. This element forms about 5 per cent of the total food, and is taken chiefly during September, when it amounts to 24 per cent of the food of the month. A little amaranth and lamb's-quarters are eaten; and gromwell, chickweed, wood sorrel, sedge, violet, and sheep sorrel are all represented in the diet. But the principal weed seeds found in the stomachs are those of ragweed and different polygonums. As a destroyer of ragweed this sparrow seems to have no equal among finches, and the Song Sparrow is its rival as a consumer of polygonums. The two weeds form 25 per cent of the food for the year, of which ragweed furnishes 9 per cent, and the polgonums 16 per cent. During October ragweed alone constitutes 45 per cent of the month's food.

"The White-throated Sparrow may be regarded as a valuable bird on the farm; it has a good record as a weed destroyer, its fruit eating is largely confined to wild berries, and it does little damage to grainfields." (Judd, "The Relation of Sparrows to Agriculture.”)

The Tree Sparrow (Spizella monticola monticola) remains with us all winter, gathering weed seed in the fields and the thickets along the brooks. "Five hundred and seventeen stomachs have been examined, collected at points ranging from Massachusetts to the District of Columbia, and westward as far as Iowa and Kansas, and during the period from October to May. As indicated by these examinations, the food of the Tree Sparrow during its stay in the United States is almost entirely made up of seeds, which amounts to 98 per cent of the total food contents of the stomachs examined. The bird shows an essential difference from its associates, however, in its large consumption of grass seed, fully half of its food consisting of this element, panicums, pigeon-grass, and allied grasses being apparently preferred." (Judd, "The Relation of Sparrows to Agriculture.")

"The Snowbird (Junco hyemalis) and Tree Sparrow (Spizella monticola) are perhaps the most numerous of all sparrows. The latter fairly swarms all over the northern states in winter, arriving from the north early in October and leaving in April. Examination of many stomachs shows that in winter the Tree 
Sparrow feeds entirely upon seeds of weeds; and probably each bird consumes about one-fourth of an ounce a day. In an article contributed to the New York Tribune in I88I the writer estimated the amount of weed seed annually destroyed by these birds in the State of Iowa. Upon the basis of one-fourth of an ounce of seed eaten daily by each bird, and supposing that the birds average ten to each square mile, and that they remain in their winter range two hundred days, we shall have a total of $1,750,000$ pounds, or 875 tons, of weed seed consumed by this one species in a single season. Large as these figures may seem, they certainly fall far short of the reality. The estimate of ten birds to a square mile is much within the truth, for the Tree Sparrow is certainly more abundant than this in winter in Massachusetts, where the food supply is less than in the western states, and I have known places in Iowa where several thousand could be seen within the space of a few acres. This estimate, moreover, is for a single species, while, as a matter of fact, there are at least half a dozen birds (not all sparrows) that habitually feed on these seeds during winter." (Beal, "Some Common Birds in their Relation to Agriculture.")

In the summer the Chipping and Field Sparrows (Spizella passerina passerina and Spizella pusilla) take the place of the Tree Sparrows, and eat also large numbers of noxious insects. The former is known to eat the cankerworm, horse-tail moth, gypsy moth, army worm, forest tent caterpillar, cabbage worm, and pea louse.

Of the Chipping Sparrow Dr. Judd writes, "Two hundred and fifty stomachs have been examined, collected from March to November, and throughout the country both in the East and West, principally, however, from New England to Virginia, and from the states of Kansas, Iowa, Illinois, and California, the greater part of the western Chipping Sparrows coming from the last named state. More collections were made in the summer and early autumn than at any other season. Of the contents of these stomachs the total animal food, consisting of insects with an occasional spider, amounts to 38 per cent; the vegetable food to 62 per cent. Of the vegetable food, 4 per cent is grain, principally oats; 48 per cent grass seed; and ro per cent other seeds, such as clover, ragweed, amaranth, wood sorrel, lamb's-quarters, 
purslane, chickweed, knotweed, and black bindweed. Twentysix per cent of the grass seed is crab-grass and pigeon-grass, chiefly the former, the rest consisting of timothy, orchard grass, and other grasses. The seeds of crab-grass, whenever they can be obtained, form the most important part of the diet. During the last of August there were collected a dozen Chipping Sparrows that were feeding in a flock amid some crab-grass and other weeds which were getting the upper hand in a small garden, about an acre in extent; and it was found that the stomach of every one of the birds was crammed full of the seeds of crab-grass."

Regarding the Field Sparrow Dr. Judd says: "The laboratory investigation includes I75 stomachs collected during every month of the year, from ${ }_{5} 5$ states and the District of Columbia, chiefly in New York, Massachusetts, and the District of Columbia in the East, and Kansas and Wyoming in the West. Of the total food they contained 4I per cent was animal matter and 59 per cent vegetable matter. Of the animal material, weevils form 2 per cent; leaf beetles, 2 per cent; ground, tiger, click, and May beetles, collectively, 9 per cent ; caterpillars, 4 per cent; grasshoppers, 6 per cent ; leaf-hoppers, true bugs, saw-flies, ants, flies, and spiders, taken together, I4 per cent; and parasitic wasps, 4 per cent. This last item is the principal point wherein the Field Sparrow differs in food habits from the Chipping Sparrow - a difference that is not to the advantage of the record of the species from an economic standpoint, since, as has been shown, these wasps are dangerous parasites of many caterpillars. Of the vegetable food $5 \mathrm{I}$ per cent consists of the seed of grasses, for the most part such species as crab-grass and other panicums, pigeon-grass, broom sedge, poverty grass (Aristida), and sheathed rush grass. Seeds of such weeds as chickweed, lamb's-quarters, gromwell, amaranth, purslane, spurge, wood sorrel, and knotweed amount to 4 per cent. The percentage of timothy is insignificant, but that of oats is comparatively large, as they constitute 4 per cent of the food." (Judd, "The Relation of Sparrows to Agriculture.")

The Slate-colored Junco (Junco hyemalis hyemalis), sometimes called the Black Snowbird, is another of our winter birds that industriously collect weed seed from field and garden. "The food habits of the Junco are such as commend it highly to the 
farmer. An examination has been made of 299 stomachs collected during every month in the year except May. They were secured chiefly along the Atlantic seaboard, but a fairly large number were obtained in the central part of the country and California.

"The food for the year, as a whole, as indicated by these stomachs, consists of animal matter 22 per cent and vegetable matter 78 per cent. The animal matter is distributed as follows: Orthoptera and Lepidoptera, each 2 per cent; Hymenoptera, 3 per cent; Coleoptera, 6 per cent; miscellaneous insects, largely Hemiptera, 7 per cent; and spiders, with a few snails and other invertebrates, 2 per cent."

"When the bird migrates to fertile districts and extends over the whole of the United States in autumn to remain until spring, it becomes a most important and useful bird. The animal food at this time, which is of the usual character, is too small to be important. The vegetable food, which constitutes 9I per cent of the diet, may be conveniently divided into three nearly equal parts; the first of which is largely timothy, broom sedge, sheathed rush grass, pigeon-grass, crab-grass and other panicums, paspalum, and a small quantity of grain; the second comprises ragweed and polygonums; and the third includes the seeds of various plants the majority of which are such weeds as amaranth, lamb's-quarters, chickweed, purslane, tick-trefoil, vetch, gromwell, wood sorrel, sedge, sheep sorrel, wild sunflower, and Russian thistle. The seeds of amaranth and lamb's-quarters are by far the most important in the diet. Few other sparrows eat as many of these seeds as the Junco, which feeds on them chiefly in March, when, doubtless, other and more palatable seeds are too scarce to be easily obtained.

"The effect of the Junco during its stay on agricultural land is that of an unmixed benefit, because the good done by its extensive consumption of weed seeds is not counterbalanced by any real harm; even the slight tendency toward eating grain is practically harmless, since most of the grain eaten consists of waste kernels." (Judd, "The Relation of Sparrows to Agriculture.”)

The Song Sparrow (Melospiza melodia melodia) is in the summer the most abundant of our sparrows, and some remain with us throughout the year. "Its food, as indicated by the examination of 401 stomachs from 26 States and British Colum- 
bia, collected during every month of the year, consists of animal matter, insects with occasionally a spider or snail, 34 per cent; and vegetable matter, mostly seeds, 66 per cent.".

"Of the vegetable portion ( 66 per cent) of the year's food, 3 per cent consists of ragweed, 5 per cent of grain, I6 per cent of polygonum and related seeds, 24 per cent of grass seed, and 18 per cent of miscellaneous seeds, such as those of wild sunflower, amaranth, lamb's-quarters, clover, gromwell, rib-grass, wild solanum, purslane, spurge, wood sorrel, dandelion, chickweed, dock, and sheep sorrel. The last two are seldom eaten by most other birds. More polygonum seed is taken by the Song Sparrow than by any other sparrow, largely because most polygonums grow in moist places where Song Sparrows are often very abundant. Several species of polygonums are weed pests on low ground, and much good is done by the systematic destruction of their seeds by the Song Sparrow during every month in the year. More than half the grass-seed food belongs to such troublesome species as crab-grass and pigeon-grass. The bird is so numerous that it must destroy large quantities of these weeds. The seeds of other grasses, such as timothy, paspalum, old-witch grass, barnyard grass, tall smooth panicum, spreading panicum, beard grass (Andropogon), orchard grass, sheathed rush grass, wild rye, wild rice, and others, form about 8 per cent of the food.

"The Song Sparrow, like the White-throated, White-crowned, and Fox Sparrows, manifests a taste for fruit, especially during July, when blackberries, raspberries, strawberries, blueberries, mulberries, and wild black cherries are eaten to the extent of nearly 8 per cent of the food. This diet is largely abandoned when the weed-seed harvest is mature, though the bird occasionally feeds with others on the ripening crop of wild fruits during late summer and autumn. It has been observed eating elderberries, wild grapes, pokeberries, bayberries, and berries of the woodbine; but, in spite of this taste and the bird's abundance among cultivated berry patches, it never, to any appreciable extent, does any damage to cultivated fruit.

"Insects amount to about one-third of the animal diet, and from May to August, inclusive, when they are eaten most freely, compose more than half the food." 
"Taking the food habits of the Song Sparrow as a whole, it will be readily seen that this bird does much more good than harm and is worthy of protection and encouragement. Only 2 per cent of the food consists of useful insects, while I8 per cent is composed of injurious insects; and grain, largely waste, amounts to only 4 per cent, while the seeds of various species of weeds constitute 50 per cent." (Judd, "The Relation of Sparrows to Agriculture.")

The food of the Lincoln's and Swamp Sparrows (Melospiza lincolni lincolni and georgiana) resembles that of the Song Sparrow, as does that of the White-crowned (Zonotrichia leucophrys leucophrys) that of the White-throated Sparrow.

The food of the Fox Sparrow (Passerella iliaca iliaca), a common migrant, "as indicated by the examination of 127 stomachs, collected principally in the eastern states, and during every month excepting June, July, and August, consists of animal matter I4 per cent, and vegetable matter 86 per cent. The animal food is of little interest excepting in the month of April, when the bird begins eating largely of millepeds of the Julus group20 per cent of the food for the month consisting of these invertebrates,- and at the same time develops such a taste for ground beetles as to raise this item of its month's diet to Io per cent. The quantity of these useful insects destroyed during the summer, when the bird is in its home in the far north, is probably much less.

" The vegetable food differs from that of most other sparrows, in that it contains less grass seed (only I per cent), less grain, and more fruit, ragweed, and polygonum. Half of the food consists of ragweed and polygonum, and more than a quarter of fruit. In its dependence on fruit the Fox Sparrow resembles the Whitethroated Sparrow. It does no direct damage to cultivated fruit, though it occasionally eats the buds of peach trees and pear trees. Bradford Torrey has observed it feeding on the fruit of burning bush (Euonymus americana). C. K. Averill, Bridgeport, Conn., reports that he has found it eating the berries of the red cedar (Juniperus virginiana), and James H. Gaut, of the Biological Survey, says that he has seen it feeding on pokeberries in November in Washington. 
"But, although 28 per cent of the food contents of the stomachs examined consisted of the seeds of berries and of fruit skin, it is safe to say that barely a third of this percentage represents actual fruit destruction, and that the remaining two-thirds of the seeds were eaten after the pulp of the fruit had been removed by other agents." (Judd, "The Relation of Sparrows to Agriculture.”)

In the stomach of a Towhee (Pipilo erythrophthalmus erythrophthalmus) were found "a locust, a mining beetle, a weevil, a ground beetle, a bug, a cricket, 6 ants, and the remains of broken seeds" (Judd, "Birds of a Maryland Farm"). "Its food consists of small seeds, grains, and fruits, as well as many insects ; among the latter are included moths, beetles, ants, wasps and ichneumon-flies, cockroaches, grasshoppers, walking-sticks and their eggs, besides larvæ of many kinds. The young are fed upon insects similar to those eaten by the adults." (Weed and Dearborn, "Birds in their Relation to Man.")

Regarding the Rose-breasted Grosbeak (Zamelodia ludoviciana), Professor Beal says: "When the Colorado potato beetle first swept over the land, and naturalists and farmers were anxious to discover whether or not there were any enemies which would prey upon the pest, the Grosbeak was almost the only bird seen to eat the beetles. Further observation confirmed the fact, and there can be no reasonable doubt that where the bird is abundant it has contributed very much to the abatement of the pest ' which has been noted during the last decade. But this is not the only good which the bird does, for many other noxious insects besides the potato beetle are also eaten.

"The vegetable food of the Grosbeak consists of buds and blossoms of forest trees, and seeds, but the only damage of which it has been accused is the stealing of green peas. The writer has observed it eating peas, and has examined the stomachs of several that had been killed in the very act. The stomachs contained a few peas and enough potato beetles, old and young, as well as other harmful insects, to pay for all the peas the birds would be likely to eat in a whole season. The garden where this took place adjoined a small potato field which earlier in the season had been so badly infested with the beetles that the vines were completely riddled. The Grosbeaks visited the field every day, 
and finally brought their fledged young. The young birds stood in a row on the topmost rail of the fence, and were fed with the beetles which their parents gathered. When a careful inspection was made a few days later, not a beetle, old or young, could be found; the birds had swept them from the field and saved the potatoes.

"It is not easy to advise measures either for increasing the numbers of this bird or inducing it to take up its residence on the farm. Naturally it inhabits thin, open woods or groves, and the change from such places to orchards would be simple-in. fact, has already been made in some parts of Pennsylvania and Ohio. In New England the bird is somewhat rare, and perhaps the best that can be done here or elsewhere is to see that it is thoroughly protected." (Beal, "Some Common Birds in their Relation to Agriculture.")

\section{TANAGERS.}

\section{Tangaridce.}

The Scarlet Tanager (Piranga erythromelas) is known occasionally to take fruit, but this only incidentally. Those taken in May and August, Dr. Judd writes, have fed exclusively on insects. "Its food consists mostly of insects of which it takes a varied assortment. The stomachs of various specimens have been found to contain ants, ichneumon-flies, including what was thought to be the large Thalessa lunator, many caterpillars, crane-flies and other Diptera, curculios, click beetles, leaf chafers, and various other beetles, grasshoppers, a few bugs, an occasional dragon-fly or spider, and several harvest spiders. A single Nebraska specimen shot in the autumn of 1874 contained thirty-seven locusts. Three nestlings less than a week old, examined by Professor King, had eaten four caterpillars, one fly, one small grasshopper, one bug, besides undetermined fragments." (Weed and Dearborn, "Birds in their Relation to Man.")

\section{SWALLOWS.}

\section{Hirundinida.}

The Swallows, among which the Purple Martin (Progne subis subis) is included, are all strictly insectivorous and may be discussed together. 
"Field observation will convince any ordinarily attentive person that the food of swallows must consist of the smaller insects captured in mid-air, or perhaps in some cases picked from the tops of tall grass or weeds. This observation is borne out by an examination of stomachs, which shows that the food consists of many small species of beetles which are much on the wing, many species of Diptera (mosquitoes and their allies), with large quantities of flying ants, and a few insects of similar kinds. Most of them are either injurious or annoying, and the numbers destroyed by swallows are not only beyond calculation, but almost beyond imagination.

"The White-bellied Swallow eats a considerable number of berries of the bayberry, or wax myrtle. During migrations and in winter it has a habit of roosting in these shrubs and it probably obtains the fruit at that time." (Beal, "Some Common Birds in their Relation to Agriculture.")

"Thirty swallows, collected between the middle of May and the middle of August, had eaten nothing but insects. Parasitic wasps and bees formed 2 per cent of their food (less than usual with aerial feeders), bugs 3 per cent, May-flies 8 per cent, beetles I 3 per cent, white ants 21 per cent, ants 33 per cent, and miscellaneous insects, principally flies with a few bugs, 20 per cent. The forms selected were bees of the family Andrenidx, and parasitic wasps of the families Scoliidæ, Ichneumonidæ, and Chalcididæ. The beetle food was interesting, for, besides click beetles, dung beetles (Aphodius inquinatus, Hister, Atcnius, and Onthophagus pennsylvanicus), weevils of several species, and metallic wood-borers ( $A$ grilus), it included the engraver beetles (among them Tomicus cacographus), which are destroyed by only a few other birds. The food of Swallows is peculiar in its lack of caterpillars and grasshoppers, which are so important to the subsistence of other birds. As with Flycatchers, the number of flies taken is generally overestimated. In the stomachs examined were found snipe-flies (Leptidce), golden-green fleshflies (Lucilia casar), and other Muscidæ, with an occasional banded-winged horsefly (Chrysops)." (Judd, "Birds of a Maryland Farm.") During a "locust year" in Nebraska 34 and 37 locusts have been taken from the stomachs of two Barn Swallows (Hirundo erythrog'astra), and 229 from six Cliff or Eave Swal- 
lows (Petrochelidon lunifrons lunifrons). The Tree or Whitebellied Swallows (Iridoprocne bicolor) collect on our salt marshes in enormous flocks in late summer, and as they skim back and forth over the shallow pools do what is possible to lessen the plague of mosquitoes. With them associate smaller numbers of Bank Swallows (Riparia riparia), and join in the hunt for flying insects of all kinds. Messrs. Weed and Dearborn state that ten Purple Martins (Progne subis subis) examined by Professor Aughey in Kansas had eaten 265 locusts, besides 16 I other insects. This bird is said to kill a few honey-bees, but this must be forgiven it for its good qualities.

\section{WAXWINGS.}

\section{Bombycillida.}

The Cedar Waxwing (Bombycilla cedrorum) is a capital flycatcher, darting from a twig and seizing insects in the air with the skill of a Kingbird. The stomachs of seven shot in an orchard infested with cankerworms were found by Professor Forbes to contain over 100. worms apiece, and they are said also to feed freely on the elm-tree beetle. "Its proverbial fondness for cherries has given rise to its popular name, and much complaint has been made on account of the fruit eaten. Observation has shown, however, that its depredations are confined to trees on which the fruit ripens earliest, while later varieties are comparatively untouched. This is probably owing to the fact that, when wild fruits ripen, they are preferred to cherries, and really constitute the bulk of the Cedar Bird's diet.

"In I52 stomachs examined animal matter formed only I3, and vegetable 87 per cent, showing that the bird is not wholly a fruit eater. With the exception of a few snails, all the animal food consisted of insects, mainly beetles, and all but one more or less noxious, the famous elm leaf beetle being among the number. Bark or scale lice were found in several stomachs, while the remainder of the animal food was made up of grasshoppers, bugs, and the like. Three nestlings were found to have been fed almost entirely on insects.

"Of the 87 per cent of vegetable food, 74 consisted entirely of wild fruit or seeds, and I 3 of cultivated fruit, but a large part 
of the latter was made up of blackberries and raspberries, and it is very doubtful whether they represented cultivated varieties. Cherry stealing is the chief complaint against this bird; but of the 152 stomachs only 9, all taken in June and July, contained any remains of cultivated cherries, and these aggregate but 5 per cent of the year's food. As 4I stomachs were collected in those months, it is evident that the birds do not live to any great extent on cultivated cherries.

"Although the cherry bird is not a great insect destroyer, it does some good work in this way, since it probably rears its young mostly upon insect food. On the other hand, it does not devour nearly as much cultivated fruit as has been asserted, and most if not all of the damage can be prevented. The bird should therefore be considered a useful species, and as such should be accorded all possible protection." (Beal, "Some Common Birds in their Relation to Agriculture.")

\section{SHRIKES.}

\section{Laniida.}

The only Shrike at all common with us is the Northern Shrike or Butcher-bird (Lanius borealis), and that occurs only in winter. The Migrant Shrike (Lanius ludovicianus migrans), a variety of the Loggerhead, is known only as a rather rare migrant. The name Butcher-bird comes from the habit these birds have of impaling their prey - mice, grasshoppers, or small birds - on a thorn or a sharp twig of a tree. "The food habits of the Shrikes, so far as determined from the examination of I55 stomachs, collected during every month of the year, from Saskatchewan to Florida and from the Atlantic to the Pacific, are very similar to those of the Sparrow Hawk; that is to say, the food consists of mice, small birds, and insects, the latter mainly grasshoppers. Both birds are much less insectivorous in cold than in warm weather - the oncoming of winter and consequent increasing scarcity of insects necessitating a change in food.

"In discussing the insectivorous habits of the Shrike, it is hardly necessary to state that the destruction of grasshoppers is a great service to the farmer. The Shrike also devours a large number of beetles, and often eats caterpillars, wasps, and spiders. Since it takes practically no vegetable food, it cannot injure crops, 
unless indirectly, by killing birds and insects that prey upon insect pests. The birds selected, however, are for the most part seed eaters, and consequently less valuable than the insectivorous kinds; and, if it be granted that.the harm done by destruction of one of these birds is counterbalanced by the killing of one mouse, then it follows that the harm done by the Shrike in killing birds is completely offset. Furthermore, the attacks of the Shrike are often directed against the English Sparrow, now so obnoxious in many parts of the United States. Concerning the insect food, it may be safely stated that the percentage of noxious grasshoppers is four times as great as that of the useful ground beetles.

"In considering the relation of the Shrikes to agriculture, it must be remembered that one inhabits a fertile country where cultivation yields heavy crops, while the other lives in a northern region where agriculture amounts to very little. Therefore, the good or harm done by the Northern Butcher-bird must be mainly accomplished when it migrates south into the United States. From the present limited investigation, it appears that the beneficial qualities of both Shrikes outweigh the injurious. Furthermore, it is probable that when it is possible to study the summer food habits of the Butcher-bird, this species, like its southern relative, the Loggerhead, will be found to be a destroyer of quantities of grasshoppers and other noxious insects." (Judd, "The Food of Shrikes.”)

The Northern Shrike during its winter sojourn "renders a threefold service by killing grasshoppers, English Sparrows, and mice. The birds and mice together amount to 60 per cent, and insects to 40 per cent, of the food from October to April. Grasshoppers constitute one-fourth of the food, and are equal to twice the combined amounts of beetles and caterpillars.

"Apparently no mineral or vegetable matter is intentionally swallowed. Indeed, its exclusively animal diet makes it, practically, a bird of prey, and therefore we must consider what animals it destroys.

" The Chippewa Indians call this Shrike 'big cannibal bird,' and several instances of cannibalism are recorded. In one case a hungry Butcher-bird pounced upon and carried off his companion, which had been shot and laid on the top of a log cabin. 
The Butcher-bird, when impelled by extreme hunger, becomes very bold, and has been known to enter a room and decapitate a caged canary.

"In the stomachs of the 67 Butcher-birds examined, 28 species of seed-eating birds were found. Of these 3 were Tree Sparrows, 5 Juncos, and 7 English Sparrows; the others could not be named with certainty. The Tree Sparrows and Juncos were found in Shrikes that had been taken in rural districts. On the other hand, English Sparrows were found only in stomachs of birds that had been collected in cities.

"In speaking of the enemies of the English Sparrow, Professor W. B. Barrows says:

" Probably the most useful bird in this respect is the Northern Shrike (Lanius borealis), which visits most of our northern cities in winter and feeds freely on the sparrow. At one time this Shrike became so abundant on the Common and public parks in Boston that it threatened to destroy all the sparrows, but the short-sighted authorities kept a man busy shooting the Shrikes, until several dozen had been killed, and the useless sparrows were considered safe.'

"It is to be hoped that in other cities this enemy of the sparrow will be protected instead of persecuted. If there were six Butcher-birds in each of 20 New England cities, and each Butcherbird killed one sparrow a day for the three winter months, the result would be a removal of 10,800 sparrows. Since two sparrows could raise under favorable conditions four broods of five each, the increase would be tenfold, so that those destroyed by the Butcher-birds, if allowed to live, would have amounted at the end of the first year to 118,800 , and at the end of the second year to $1,306,800$ individuals."

"Mice were found in one-third of the stomachs examined, constituting one-fourth of the food, and were eaten most frequently in March. Of these mice 15 were identified as follows: I white-footed mouse (Peromyscus), I harvest mouse (Reithrodontomys), and 8 meadow mice (Microtus)."

"Active insects are much more liable than sluggish ones to fall victims to the Butcher-bird, because objects which at rest cannot be discriminated are instantly seen when moving. Thus it happens that flying grasshoppers and running beetles form a 
large proportion of the food of this bird. Grasshoppers and crickets (Orthoptera), which are eaten during every month from October to April, form 24 per cent of the total volume of food, and for October and November together these insect pests form more than half of the food." (Judd, "The Food of Shrikes.")

Dr. Judd gives a list of I7 species of our small birds that this Shrike has been known to kill.

Of the stomachs of 9 Northern Shrikes taken in Connecticut between November 6th and March Ist, examined by the author, I contained a mammal ; 4, birds; 4, insects, chiefly grasshoppers; and $I$, feathers and seeds.

By the Loggerhead Shrike, of which our Migrant Shrike is a subspecies, I 3 species of birds have been known to be killed; but the studies of the Biological Survey show that birds constitute a smaller proportion of its food than they do of its larger relative, its diet being chiefly insects. Of the stomachs of 5 Connecticut specimens of the Migrant Shrike taken between Oct. 2 and Feb. I5, examined by the author, I contained a bird; 4, grasshoppers; and I, beetles.

\section{VIREOS.}

\section{Vireonide.}

Insects in form of egg, larva, pupa, or adult are the proper food of the Vireos, and are sought for industriously by them over the branches and under the leaves of our trees during the months they are with us. "Twenty-five Vireos were collected, including 2 Warbling Vireos (Vireo gilvus), to White-eyed Vireos (Vireo noveboracensis), and I3 Red-eyed Vireos (Vireo olivaceus). Ninety-one per cent of their food consisted of insects, and 9 per cent of fruit (mulberries and sassafras). Parasitic wasps formed 2 per cent, ants and other Hymenoptera 6 per cent, May-flies 4 per cent, caterpillars I 5 per cent, bugs 17 per cent, beetles 28 per cent, miscellaneous insects 8 per cent, and spiders II per cent. The Hymenoptera, other than ants, comprised jointworm flies, sawfly larvæ, ichneumon flies, and bees of the genus Halictus."

"The bugs were stink-bugs (Podisus), leaf-hoppers (Jassidæ), and scale insects (Kermes). The Yellow-throated Vireo (Vireo flavifrons) has been noted at Marshall Hall by Mr. William 
Palmer. All the Vireos are very useful protectors of forest and fruit trees." (Judd, "Birds of a Maryland Farm.")

Insects of many kinds are given to the young and occasionally raspberries and blackberries. They are among our most useful birds.

Red-eyed Vireo (Vireosylva olivacea).- "From the stomachs of eighteen of this species were taken fifteen caterpillars; five other larvæ; eight beetles - among them five weevils, one longhorn and one darkling beetle; seventy heteropterous insects among them sixty-seven chinch-bugs; sixteen winged ants; one ichneumon; five dragon-flies; two dipterous insects - one of them Tabanus atratus; and seven dogwood berries. Of thirtysix other specimens examined, fifteen had eaten caterpillars; two, other larvæ; nine, beetles - among them two Coccinella mali; three, grasshoppers; two, ants; two, moths; four, insects none of which were identified; and seven, fruit or seeds, among which were raspberries, dogwood berries, berries of prickly ash, and sheep berries."

Yellow-throated Vireo (Lanivireo flavifrons).- " Of twentyone specimens examined, seven had eaten caterpillars - among them geometers; seven, beetles - among them weevils and a buprestis; three, grasshoppers; two, moths; two, heteropterous insects - among them leaf-hoppers; three, dipterous insects."

Warbling Vireo (Vireosylva gilvus).-."Of sixteen specimens examined, eight had eaten thirty-four caterpillars; two, five beetles, among which were a ladybird (Coccinella sex-notata), and a Dibrotica duodecim-punctata: three, three heteropterous insects; two, two crane-flies; one, grasshopper; two, twenty-eight insects' eggs; and one, dogwood berries." (King, in Chapman, "The Economic Value of Birds to the State.")

The White-eyed Vireo (Vireo griseus griseus) is a common summer resident of the tangled thickets of our southern border. "The food of this species in early summer is almost exclusively small insects, which it gleans with great assiduity. In eastern Massachusetts, like all its kindred, it feeds eagerly upon the young larvæ of the destructive cankerworm, and doubtless, in the wilder portions of the country, is of considerable service in restricting the increase of this scourge." (Baird, Brewer, and Ridgway, "North American Birds.") 
WOOD WARBLERS.

\section{Mniotiltida.}

Next to the Sparrows in point of numbers, the Warblers fill the same good office against insects that the former do against weeds. "The Warblers have we always with us - all, in their own good time; they come out of the South, pass on, return, and are away again, their appearance and withdrawal scarcely less than a mystery; many stay with us all summer long, and some brave the winters in our midst. Some of these slight creatures, guided by unerring instinct, travel true to the meridian in the hours of darkness, slipping past like a 'thief in the night,' stopping at daybreak from their lofty flights to rest and recruit for the next stage of the journey. Others pass more leisurely from tree to tree, in a ceaseless tide of migration, gleaning as they go; the hardier males, in full song and plumage, lead the way for the weaker females and the yearlings. With tireless industry do the Warblers befriend the human race; their unconscious zeal plays due part in the nice adjustment of nature's forces, helping to bring about the balance of vegetable and insect life without which agriculture would be in vain. They visit the orchard when the apple and pear, the peach, plum, and cherry, are in bloom, seeming to revel carelessly amid the sweet-stented and delicately-tinted blossoms, but never faltering in their good work. They peer into the crevices of the bark, scrutinize each leaf, and explore the very heart of the buds, to detect, drag forth, and destroy those tiny creatures, singly insignificant, collectively a scourge, which prey upon the hopes of the fruit grower, and which, if undisturbed, would bring his care to nought. Some Warblers flit incessantly in the terminal foliage of the tallest trees; others hug close to the scored trunks and gnarled boughs of the forest kings; some peep from the thicket, the coppice, the impenetrable mantle of shrubbery that decks tiny watercourses, playing at hide-and-seek with all comers; others more humble still descend to the ground, where they glide with pretty mincing steps and affected turning of the head this way and that, their delicate flesh-tinted feet just stirring the layer of withered leaves with which a past season carpeted the ground. We may seek warblers everywhere in their season; we shall find them a continual surprise ; all mood and cir- 
cumstance is theirs." (Coues, "Birds of the Colorado Valley.")

"Of the food of the 53 specimens collected, 96 per cent consisted of insects, and 4 per cent of fruit. The insect food was distributed as follows : beetles, $2 \mathrm{I}$ per cent; ants, wasps, and bees, I 8 per cent; May-flies, 16 per cent ; caterpillars, I4 per cent; bugs (leaf-hoppers, scale insects, and true bugs), 6 per cent; miscellaneous insects, including flies, a few grasshoppers, and others, 8 per cent; spiders, II per cent; and miscellaneous invertebrates, principally snails, 2 per cent. Of the $2 \mathrm{I}$ per cent of beetles, 3 per cent were useful forms, 5 per cent neutral, and I3 per cent injurious." (Judd, "Birds of a Maryland Farm.")

Of the individual species it is necessary to say little, as their food is practically the same - insects almost exclusively,- although the Myrtle Warbler (Dendroica coronata) feeds on bayberries frequently in winter. The Tennessee Warbler (Vermivora peregrina) in some parts of the country pierces grapes, but with us it is hardly more than a straggler. A Nebraskan Black and White Warbler (Mniotilta varia) has been known to eat $4 \mathrm{I}$ locusts and $2 \mathrm{I}$ other insects at a meal; while from the stomachs of two Wisconsin birds were taken 2I caterpillars. Two Myrtle Warblers were found by Professor King to have eaten $2 \mathrm{I}$ caterpillars, mostly measuring-worms; five, to have eaten I4 twowinged flies, among which were three crane-flies; and I5, to have eaten 48 beetles. "Two-thirds of the food of five Illinois Yellow Warblers (Dendroica cestiva cestiva) consisted of cankerworms, and most of the remainder was an injurious beetle." The Maryland Yellowthroat (Geothlypis trichas trichas) "especially frequents the shrubbery about standing or running water, where it can be found throughout the summer busily searching for insect food. It often visits orchards, where cankerworms and other caterpillars are greedily devoured, these forming in three cases on record four-fifths of its food. The little case-bearing caterpillars of the genus Coleophora and its allies are often eaten, while butterflies, moths, two-winged flies, beetles, grasshoppers, leaf-hoppers, bugs, dragon-flies, Hymenoptera, and insects' eggs are all included on the bill of fare. The young are sometimes fed with small grasshoppers, and these insects are a favorite item of food with the adult birds." (Weed and Dearborn, "Birds in their Relation to Man.”) Seven Nebraskan American Redstarts 
(Setophaga ruticilla) had eaten I6I small locusts and I77 other insects; and II Wisconsin birds, I4 small beetles, 4 very small moths, 4 small hymenopterous insects, and a large number of dipterous insects. This Warbler catches insects on the wing as readily as a flycatcher. Such instances of the feeding habits of our Warblers might be multiplied indefinitely with each species of the family, but these are more than sufficient to show how indispensable these birds are to the state.

\section{PIPITS.}

Motacillide.

The American Pipit or Titlark (Anthus rubescens) might in many ways be called the Warbler of the fields, as its food is chiefly insects. "No extended study of the food habits of this species appears, to have been made. It is asserted, however, by various authors to feed on beetles, spiders, seeds in the fields, and along shore on minute shells, shrimps, etc." (Chapman, "The Economic Value of Birds to the State.")

\section{MOCKINGBIRDS and THRASHERS. \\ Mimide.}

The Catbird (Dumetella carolinensis) " always attracts attention, and the intruder upon its. haunts soon understands that he is not welcome. There is no mistaking the meaning of the sneering voice with which he is saluted, and there is little doubt that this gave rise to the popular prejudice against the bird; but the feeling has been increased by the fact that the species is sometimes a serious annoyance to fruit growers. All such reports, however, seem to come from the prairie country of the West. In New England, according to the writer's experience, the Catbird is seldom seen about gardens or orchards; the reason may possibly be found in the fact that on the prairies fruit-bearing shrubs which afford so large a part of this bird's food are conspicuously absent. With the settlement of this region comes an extensive planting of orchards, vineyards, and small fruit gardens, which furnish shelter and nesting sites for the Catbird, as well as for other species, with a consequent large increase in their numbers, but without providing the native fruits upon which 
they have been accustomed to feed. Under these circumstances, what is more natural than for the birds to turn to cultivated fruits for their supplies? The remedy is obvious; cultivated fruits can be protected by the simple expedient of planting wild species or others which are preferred by the birds. Some experiments with Catbirds in captivity showed that the Russian mulberry was preferred to any cultivated fruit that could be offered.

"The stomachs of 213 Catbirds were examined, and found to contain 44 per cent of animal (insect), and 56 per cent of vegetable food. Ants, beetles, caterpillars, and grasshoppers constitute three-fourths of the animal food, the remainder being made up of bugs, miscellaneous insects, and spiders. One-third of the vegetable food consists of cultivated fruits, or those which may be cultivated, such as strawberries, raspberries, and blackberries; but, while we debit the bird with the whole of this, it is probable - and in the eastern and well wooded part of the country almost certain - that a large part was obtained from wild vines. The rest of the vegetable matter is mostly wild fruit, such as cherries, dogwood, sour gum, elderberries, greenbrier, spice berries, black alder, sumac, and poison ivy.

"Although the Catbird sometimes does considerable harm by destroying small fruit, the bird cannot be considered injurious. On the contrary, in most parts of the country it does far more good than harm, and the evil it does can be reduced appreciably by the methods already pointed out." (Beal, "Some Common Birds in their Relaton to Agriculture.")

Regarding the Brown Thrasher (Toxostoma rufum), Professor Beal says: "The food of the Brown Thrasher consists of both fruit and insects. An examination of I2I stomachs showed 36 per cent of vegetable and 64 of animal food, practically all insects, and mostly taken in spring before fruit is ripe. Half the insects were beetles, and the remainder chiefly grasshoppers, caterpillars, bugs, and spiders. A few predaceous beetles were eaten, but, on the whole, its work as an insect destroyer may be considered beneficial.

"Eight per cent of the food is made up of fruits like raspberries and currants which are or may be cultivated, but the raspberries at least are as likely to belong to wild as to cultivated varieties. Grain, made up mostly of scattered kernels of oats and 
corn, is merely a trifle, amounting to only 3 per cent; and, though some of the corn may be taken from newly planted fields, it is amply paid for by the May-beetles, wild fruit, or seeds. Taken all in all, the Brown Thrasher is a useful bird, and probably does just as good work in its secluded retreats as it would about the garden, for the swamps and groves are no doubt the breeding grounds of many insects that migrate thence to attack the farmer's crops." (Beal, "Some Common Birds in their Relation to Agriculture.")

\section{WRENS.}

Troglodytida.

The House Wren (Troglodytes aëdon aëdon) is a tolerably common summer resident of our orchards. "As regards food habits, the House Wren is entirely beneficial. Practically, he can be said to live upon animal food alone, for an examination of 52 stomachs showed that 98 per cent of the stomach contents was made up of insects or their allies, and only 2 per cent was vegetable, including bits of grass and similar matter, evidently taken by accident with the insects. Half of this food consisted of grasshoppers and beetles; the remainder of caterpillars, bugs, and spiders. As the House Wren is a prolific breeder, frequently rearing from twelve to sixteen young in a season, a family of these birds must cause considerable reduction in the number of insects in a garden. Wrens are industrious foragers, searching every tree, shrub, or.vine for caterpillars, examining every post and rail of the fence and every cranny in the wall for insects or spiders. They do not, as a rule, fly far afield, but work industriously in the immediate vicinity of their nests. In this way they become valuable aids in the garden or orchard, and by providing suitable nesting boxes they may be induced to take up residence where their services will do most good. Their eccentricities in the selection of a home are well known. Almost anything from an old cigar box to a tomato can, an old teapot, a worn-out boot, or a horse's skull, is acceptable, provided it be placed well up from the ground and out of reach of cats and other prowlers.

"It does not seem possible to have too many Wrens, and every effort should be made to protect them and to encourage their nesting about the house." (Beal, "Some Common Birds in their Relation to Agriculture.") 
An evil habit of this Wren is that of destroying the eggs of other small birds by piercing them with its slender bill, and the Long-billed Marsh Wren (Telmatodytes palustris palustris) has been seen by Mr. Chapman to injure in the same manner the eggs of the Least Bittern (Ardetta exilis). This latter Wren "though like the House Wren it eats nothing but insects, cannot be expected to help crops because of the remoteness of its marshy habitat. Five birds were collected. Spiders and beetles (Calandra oryza, Donacia, Hippodamia maculata) formed the major part of their food. The minor part was composed of true bugs, leaf-hoppers, flies, parasitic wasps, and ants." (Judd, "Birds of a Maryland Farm.")

The Winter Wren (Nannus hiemalis hiemalis) lives like the others of its family on insects and spiders.

\section{CREEPERS.}

\section{Certhiidce.}

The Brown Creeper (Certhia familiaris americana) hunts systematically through our woodland and orchards for insects, flying from the top of one tree to the base of another and searching in the interstices of the bark for eggs as it proceeds slowly up the trunk. "Very few precise determinations of its food have been made: three stomachs examined by King contained small beetles and other insects, and Nelson reports that he has seen several of these Creepers on the sides of a house searching for spiders. In June, I895, Aughey saw two parent birds bring to a nest of young twenty-seven locusts in an hour. In Maryland, Judd found that one bird had eaten beetles, sawflies, flying ants, spiders, and seeds of the scrub pine. There can be no doubt that this is a very useful little bird, deserving all possible encouragement." (Weed and Dearborn, "Birds in their Relation to Man.")

\section{NUTHATCHES.}

\section{Sittida.}

Other useful gleaners of the tree trunks and the larger branches are the White-breasted and Red-breasted Nuthatches (Sitta carolinensis carolinensis, and canadensis). Regarding the 
White-breasted Nuthatch, Weed and Dearborn say: "Professor King examined the stomach contents of twenty-five Wisconsin specimens, and found that fourteen of them had eaten beetles, including elaters and longicorns, while others contained ants, caterpillars, and beetle grubs, a spider, and a chrysalis, a few small toadstools, some acorns, and a little corn. Four Illinois specimens had eaten beetles of various kinds, some of them being ladybeetles.

"The food of this species in winter and spring was made the subject of a special study by Professor E. D. Sanderson. 'During the winter the larger proportion of the food was composed of seeds, which gradually decreased as insect life became more abundant.' Seeds of Indian corn, ragweed, and wild sunflowers were recognized; the insects were largely in egg or larval stages. In spring nearly eighty per cent of the food consisted of insects, chiefly adults. No traces of acorns were found in the stomachs examined. From these studies Professor Sanderson reaches the conclusion that this species is 'either absolutely neutral or of comparatively small economic importance' - a conclusion which, it seems to us, is by no means warranted by his results. During the spring, he writes, 'Hymenoptera were found in considerable numbers, all being beneficial.' Probably it is on this account that the usefulness of the birds is doubted. But we believe that investigators err in saying that all parasitic insects are beneficial." (Weed and Dearborn, "Birds in their Relation to Man.")

The feeding habits of the Red-breasted Nuthatch are similar.

\section{TITMICE.}

\section{Parida.}

Taking up the work where the Creepers and Nuthatches have left it, carrying their search for insects and their eggs to the tips of the branches and the hanging leaves, and often intruding on the ground more properly belonging to the others, common and remaining with us all the year, the Chickadee (Parus atricapillus atricapillus) is probably the most useful bird we possess. "In a cankerworm-infested orchard sixty-one per cent of the food of two Chickadees consisted of these caterpillars, while injurious beetles constituted the remainder. 
"In a recent investigation of the winter food of the Chickadee, we studied the stomach contents of forty-one specimens taken during November, December, January, February, and March. The results as a whole show that more than half of the food of the Chickadees during winter consists of insects, a very large proportion of which are taken in the form of eggs. About five per cent of the stomach contents consisted of spiders or their eggs. Vegetation of various sorts made up a little less than a quarter of the food, two-thirds of which, however, consisted of buds and bud-scales that were believed to have been accidentally introduced with plant-lice eggs. These eggs made up more than one-fifth of the entire food and formed the most remarkable element of the bill of fare. This destruction of the myriads of eggs of plant-lice which infest the fruit, shade, and forest trees, is probably the most important service the Chickadee renders during its winter residence. More than four hundred and fifty eggs sometimes occur as the food of one bird in a single day. On the supposition that one hundred were eaten daily by each of a flock of ten Chickadees, there would be destroyed one thousand a day, or one hundred thousand during the days of winter - a number which we believe to be far below the actual average, could we determine it precisely. Insects' eggs of many other kinds were found in the food of the Chickadee; many of these it was impossible to recognize, but there was no difficulty in identifying the eggs of the common American tent caterpillar and of the fall cankerworm, the eggs of which remain upon the trees through the winter. There were also present the eggs and egg sacs of many spiders of kinds commonly occurring under loose bark. While spiders as a class are doubtless beneficial creatures, the destruction of some of them is not in our opinion seriously detrimental to the usefulness of the Chickadee. The larvæ of several different kinds of moths were also found. One of the most abundant species was believed to be the common apple worm, the larva of the codling moth. The bark beetles of the family Scolytidæ, which are destructive to forests all over our country, were also freely eaten by the Chickadees. The hairy skins of the fruit of the common wild sumachs were among the most abundant elements of the vegetable food present. The edible portion of these fruits is evidently eaten to a considerable 
extent throughout the winter and early spring. Another common element of the food appears to consist of the curious fruits of the bayberry or waxberry myrtle - an abundant shrub along the seacoast. In winter Chickadees have been observed to hide away surplus food, to eat at a later time.

"A careful study of the food of the Chickadee in Michigan has also been made by Professor E. D. Sanderson, with results very similar to those recorded above. As an indication of the usefulness of these birds, he writes: 'If fifty-five insects were consumed per day by each bird, as will be shown to be the case, three hundred and eighty-five would be consumed per day by a flock of seven, which is believed to be a fair average for each square mile; this would be about one hundred and thirty-seven thousand five hundred per year in each square mile. Thus upon the land surface of Michigan there will annually be about eight thousand million insects destroyed by Chickadees alone - surely no mean number." " (Weed and Dearborn, "Birds in their Relation to Man.")

Mr. Forbush reports that $\mathrm{r}, 028$ eggs of the fall cankerworm were found in the stomachs of four Chickadees killed in Massachusetts, and that four others taken later in the season had eaten ro5 female imagoes of the spring canker worm, each moth containing on the average 185 eggs. "Mr. Bailey is very positive from his continuous field observation, that each Chickadee will devour on the average 30 female cankerworm moths per day from the 2oth of March until the 15 th of April, provided these insects are plentiful. If the average number of eggs laid by each female is 185 , one Chickadee would thus destroy in one day 5,550 eggs, and in the twenty-five days in which the cankerworm moths 'run' or crawl up the trees, I38,750. It may be thought that this computation is excessive, and it is probable that some of the moths were not captured until they had laid some of their eggs, but the Chickadees are busy eating these eggs also. When we consider further that $4 \mathrm{I}$ of these insects, distended as they were with eggs, were found at one time in the stomach of one Chickadee, and that the digestion of the bird is so rapid that its stomach was probably filled many times daily, the estimate made by Mr. Bailey seems a very conservative one. He now regards the Chickadee as the best friend the farmer has, for the reason that it is with 
him all the year, and there is no bird that can compare with it in destroying the female moths and their eggs." (Forbush, "Birds as Protectors of Orchards.")

\section{KINGLETS. \\ Sylviida.}

Our Golden and Ruby-crowned Kinglets (Regulus satrapa satrapa and $R$. calendula calendula) carry on the work of the Chickadees to the flowers and to the leaf-buds, which their diminutive size allows them to investigate. Regarding the Goldencrowned Kinglet Professor King says: "Of nine specimens examined, two had eaten twelve small diptera; three, nine small beetles; one, four caterpillars; one, a small chrysalis; and three, very small bits of insects, too fine to be identified."

Of the Ruby-crowned Kinglet he says: "Of seven specimens examined, two had eaten four small caterpillars; three, five beetles; one, an ant; one, a chalcis fly; and two, bits of insects not identified." (King, "The Economic Relation of Wisconsin Birds," in Chapman, "The Economic Value of Birds to the State.")

THRUSHES, ROBINS, and BLUEBIRDS.

\section{Turdida.}

Our Thrushes are all insectivorous, and in feeding habits closely resemble each other. "In summarizing the food of the family of Thrushes as it occurs in Illinois, Professor Forbes says: ' Sixty-one per cent of the food consists of insects, one per cent of spiders, two per cent of myriapods, and thirty-two per cent of fruits, eleven per cent being blackberries, eight per cent cherries, one per cent currants, and five per cent grapes. Thirty parts of the food consist of injurious insects, and eight parts of beneficial species, while twenty-six parts consist of edible fruits. This, however, refers only to the adult birds, the food of the young not being sufficiently known to be included in the estimate. All the observations on record indicate that the nestlings of Thrushes are fed upon insects, especially smooth caterpillars like the cutworms, so that there is little doubt that this factor would largely increase the already conclusive evidence as to the great value 
of this splendid family." (Weed and Dearborn, "Birds in their Relation to Man.")

Of the Wood Thrush (Hylocichla mustelina) Mr. Chapman says: "Professor Forbes writes, after examining the contents of twenty-two birds of this species: 'Seventy-one per cent of their food consists of insects, and twenty per cent of fruit, a small ratio of spiders and mollusks, and an unusually large percentage of Myriopoda making up the remainder.' After discussing in detail the bird's economic relations, the same author adds: 'Its advances, therefore, are to be cordially encouraged by the gardener and farmer - a fact which must be especially agreeable to every lover of bird music, who has learned to recognize the full, clear, rich, exquisite strains of this songster.'" (Chapman, "The Economic Value of Birds to the State.")

The stomachs of three Gray-cheeked Thrushes (Hylocichla alicice alicice) collected in May were found by Dr. Judd to contain sawfly larvæ, ants, caterpillars, May-flies, ground beetles, weevils, and scarabæid beetles; while two Olive-backed Thrushes (Hylocichla ustulata swainsoni), also collected in May, had eaten ants, wasps, ground beetles, darkling beetles, and ground spiders.

Regarding the Hermit Thrush (Hylocichla guttata pallasi), Professor Forbes reports as follows on the food contents of the stomachs of twenty-one Hermit Thrushes: "Eighty-four per cent of the food consisted of insects, four per cent of spiders, and twelve per cent of thousand-legs. Ants amounted to fifteen per cent, Lepidoptera to nineteen per cent, including a few Phalænidæ, and Diptera only to three - chiefly the larvæ of Bibio. Coleoptera make thirty per cent of the food, eleven per cent being Carabidæ." (Forbes, "The Food of Birds": Bull. 3, Illinois State Laboratory of Nat. Hist.)

The food of the Wilson's Thrush (Hylocichla fuscescens fuscescens) is doubtless similar to that of our other Thrushes; but, were its only claim on our regard its "clear, bell-like notes, resonant, distinct, yet soft and of indescribable sadness," it would still well deserve protection.

The American Robin (Planesticus migratorius migratorius) needs no introduction. "With the exception of the English Sparrow and possibly the Crow, the economic status of no American bird has been discussed so fully and freely as that of the 
Robin. Appearing early in the spring and remaining late in the autumn in regions where it does not reside throughout the year, commonly frequenting lawns and meadows, building conspicuous nests near the haunts of man, feeding freely upon the fruits of the garden and orchard, greeting the rising and the setting sun with bursts of no mean melody - these and other considerations have combined to render the Robin familiar to every lover of the outdoor world." (Weed and Dearborn, "Birds in their Relation to Man.") But, while the evidence is strongly against the English Sparrow and hardly in favor of the Crow, there can be no doubt that, in spite of its taste for fruit, the Robin is a very useful bird and should be thoroughly protected. Professor Forbes found that 99 per cent of the food of II Robins shot in February in Illinois consisted of insects, of which cutworms and other caterpillars constituted I4 per cent, and the larvæ of the white-winged Bibio 76 per cent. "Thirty-seven per cent of the food of nine March robins consisted of Bibio larvæ; cutworms and other caterpillars formed 30 per cent." "Taking the year as a whole, insects form almost two-thirds of the food of the Robin." "Six robins shot in Nebraska by Professor Aughey had eaten two hundred and sixty-five Rocky Mountain locusts and eighty-four other insects. In Wisconsin Professor King examined the stomachs of thirty-seven specimens taken during the interval between March and October. 'Five birds had eaten eleven cutworms; three, five wire-worms; two, two hairy caterpillars; one, a hog-caterpillar of the vine; five, eight scarabæid beetles; two, curculios; one, a click beetle; one, an ichneumon fly ; two, two spiders; one, a millipede; two, two angle-worms; six, nine grasshoppers; two, eight grasshoppers' eggs; one, a moth ; three (young birds), pellets of grass; one, choke-cherries; two, black cherries; one raspberries; one, grapes; one, sheep berries; and one, berries of Indian turnip."

"Concerning the fruit-eating proclivities of the Robin, Mr. W. J. Green, of the Ohio Agricultural Experiment Station, writes: 'The capacity of the Robin for berries is enormous, and when hundreds come at once the growers suffer serious losses. On the station ground nearly all of the early raspberries and blackberries are taken by the Robins, and only in the height of the season are there enough berries left to give the pickers a chance 
to earn fair wages. If left to themselves the Robins would take the greater share of the black raspberries that grow on a plantation of more than an acre. Growers in other parts of the country have complained of losses quite as large.'

"The above accounts relate to the food of the adult Robins. We have next to consider that of the nestlings. Properly to appreciate the importance of the latter, we must remember that as far north as Massachusetts three broods of nestlings are commonly reared; that from early spring till late in the summer each pair of old birds is engaged at least half of the time in providing food for four, five, or six ravenous birdlings; and that each of the latter probably requires more food while in the nest than does one of the adults during the same period. It seems to us that the chief claim of the Robin upon man's favor rests upon these facts.

"In I884 we examined the stomach contents of six young Robins from Michigan nests. The largest single element of the food consisted of cutworms and related caterpillars, which formed twenty-seven per cent of the total dietary. Among other insects present were seven per cent of beetles, including curculios and ground beetles and various undetermined species. There were also present twenty per cent of earthworms, one per cent of snails, three per cent of myriapods, and about thirty per cent of grass blades. The latter seem almost always to be found in the stomachs of nestling Robins; they may be introduced accidentally with the cutworms or possibly may have a dietetic value.

"The food of fourteen nestlings examined by Beal consisted of caterpillars, locusts, grasshoppers, crickets, and beetles, with a few spiders, snails, and earthworms, and seven per cent of berries of various kinds." (Weed and Dearborn, "Birds in their Relation to Man.")

"An examination of 330 stomachs shows that over 42 per cent of its food is animal matter, principally insects, while the remainder is made up largely of small fruits or berries. Over I9 per cent consists of beetles, about one-third of which are useful ground beetles, taken mostly in spring and fall, when other insects are scarce. Grasshoppers make up about one-tenth of the whole food, but in August comprise over 30 per cent. Caterpillars form about 6 per cent, while the rest of the animal food, 
about 7 per cent, is made up of various insects, with a few spiders, snails, and angle-worms. All the grasshoppers, caterpillars, and bugs, with a large portion of the beetles, are injurious, and it is safe to say that noxious insects comprise more than one-third of the Robin's food.

"Vegetable food forms nearly 58 per cent of the stomach contents, over 47 being wild fruits, and only a little more than 4 per cent being possibly cultivated varieties. Cultivated fruit amounting to about 25 per cent was found in the stomachs in June and July, but only a trifle in August. Wild fruit, on the contrary, is eaten in every month, and constitutes a staple food during half the year. No less than forty-one species were identified in the stomachs; of these the most important were four species of dogwood, three of wild cherries, three of wild grapes, four of greenbrier, two of holly, two of elder; and cranberries, huckleberries, blueberries, barberries, service-berries, hackberries, and persimmons, with four species of sumac, and various other seeds not strictly fruit. The depredations of the Robin seem to be confined to the smaller and earlier fruits; and few, if any, complaints have been made against it on the score of eating apples, peaches, pears, grapes, or even late cherries. By the time these are ripe the forests and hedges are teeming with wild fruits, which the bird evidently finds more to its taste. The cherry, unfortunately, ripens so early that it is almost the only fruit accessible at a time when the bird's appetite has been sharpened by a long continued diet of insects, earthworms, and dried berries; and it is no wonder that at first the rich, juicy morsels are greedily eaten. In view of the fact that the Robin takes ten times as much wild as cultivated fruit, it seems unwise to destroy the birds to save so little. Nor is this necessary, for by a little care both may be preserved. Where much fruit is grown, it is no great loss to give up one tree to the birds; and in some cases the crop can be protected by scarecrows. Where wild fruit is not abundant, a few fruit-bearing shrubs and vines judiciously planted will serve for ornament and provide food for the birds. The Russian mulberry is a vigorous grower and a profuse bearer, ripening at the same time as the cherry, and, so far as observation has gone, most birds seem to prefer its fruit to any other. It is believed that a number of these trees planted around the garden or 
orchard would fully protect the more valuable fruits." (Beal, "Some Common Birds in their Relation to Agriculture.")

The Bluebird (Sialia sialis sialis) "frequents orchards and gardens, where it builds its nest in hollow trees or takes advantage of a nesting box provided by the enterprising farmer's boy.

"So far as known this bird has not been accused of stealing fruit or of preying upon any crops. An examination of 295 stomachs showed that 76 per cent of the food consists of insects and their allies, while the other 24 per cent is made up of various vegetable substances, found mostly in stomachs taken in winter. Beetles constitute 28 per cent of the whole food, grasshoppers 22, caterpillars II, and various insects, including quite a number of spiders, comprise the remainder of the insect diet. All these are more or less harmful, except a few predaceous beetles, which amount to 8 per cent; but, in view of the large consumption of grasshoppers and caterpillars, we can at least condone this offense, if such it may be called. The destruction of grasshoppers is very noticeable in the months of August and September, when these insects form more than 60 per cent of the diet.

"It is evident that in the selection of its food the Bluebird is governed more by abundance than by choice. Predaceous beetles are eaten in spring, as they are the first insects to appear; but in early summer caterpillars form an important part of the diet, and are replaced a little later by grasshoppers. Beetles are eaten at all times, except when grasshoppers are more easily obtained.

"So far as its vegetable food is concerned, the Bluebird is positively harmless. The only traces of any useful product in the stomachs consisted of a few blackberry seeds, and even these more probably belonged to wild than cultivated varieties. Following is a list of the various seeds which were found: blackberry, chokeberry, juniper berry, pokeberry, partridge berry, greenbrier, Virginia creeper, bittersweet, holly, strawberry bush, false spikenard, wild sarsaparilla, sumac (several species), rose haws, sorrel, ragweed, grass, and asparagus. This list shows how little the Bluebird depends upon the farm or garden to supply its needs, and indicates that, by encouraging the growth of some of these plants, many of which are highly ornamental, the bird can be induced to make its home on the premises." (Beal, "Some Common Birds in their Relation to Agriculture.") 


\section{INDEX.}

Acanthis hornemanni exilipes 120,194 linaria linaria $\mathrm{I}_{20}, \mathrm{I} 92$

linaria rostrata 12I, 195

Accipiter cooperi 76, 190, 193, 273, 274, 275, 279

velox 75, I90, I93, 273, 274, 275

Actitis macularia 63, I9I, 268

Egialitis meloda 67, I93 semipalmata 66, 193

Ethiinæ I8

Agelaius phœeniceus fortis II2, I94 phoniceus phoniceus II2, II6. Igo, 303,315

Aix sponsa 33 I9I, 192

Alaudidx 105, 290

Alca torda I9, I94

Alcedinidæ 91,283

Alcidx I8, 264

Alcina 18

Alcyones $9 \mathrm{I}$

Alle alle I9, I94

Allina I9

Aluco pratincola 85 , I90

Aluconida 85

Ammodramus savannarum australis I24, I9I, 328, 329

Anas platyrhynchos 30, I92 rubripes $30,190,192$

Anatidæ 28,265

Anatinæ 30

Anseres 28

Anserinæ 40

Anthus rubescens I66, I92, I93, 348

Antrostomus carolinensis 97, I94 vociferus vociferus 97, I9I, 286

Aphrizidæ 67

Aquila chrysaëtos 8r, I04, 278

Archibuteo lagopus sanctijohannis $8 \mathrm{I}$, 192, 278

Archilochus colubris 99, I9r, 287

Ardea herodias herodias 452 I9I, I92, 266

Ardeidæ 43,265

Ardeina 45

Arenaria interpres morinella 67,193 Arenariinæ 67

Arquatella maritima maritima 56,192 , 193
Asio flammeus $86,190,193,280$ wilsonianus 86, I90, $28 \mathrm{I}$

Astragalinus tristis tristis 8, I2I, I90, 325

Astur atricapillus atricapillus 8, 77, 190, 274, 279

Auk, Little 19, I94

Razor-billed I9, I94

Auk family 18,264

Avocet $53,194,268$

Avocet family 53, 266

Bxolophus bicolor I74, I95

Baldpate 3I, I92

Bartramia longicauda 62, I9I, 193. 267,268

Birds, Diving 15

Gallinaceous 68

of Prey 73

Perching 100

Shore 52, 266

Song 105

Songless Perching 100

Bittern 43, 190, I92

Least 44, I9I, 192, 35I

Bittern family 43,265

Blackbird, Crow II5, II6, II7, I9I, 306, 315

Red-winged II2, II6, I90, 303, 3I 5

Rusty II4, II6, 193, 305

Thick-billed II2, I94

Yellow-headed III, I94

Blackbird family 109,298

Bluebird III, I80, I86, I90, 328, 360

Bobolink 8, I09, III, I9I, 300

Bob-white $68,190,268$

Bombycilla cedrorum III, I42, I90, 340

garrula 142, I95

Bombycillidæ 142,340

Bonasa umbellus togata 8,69 , I90

umbellus umbellus 8,68 , I90, 271

Booby 26, 194

Botaurinæ 43, 265

Botaurus lentiginosus 43, 190, 192

Brant 42, 192

Branta bernicla glaucogastra 42,192 canadensis canadensis $4 \mathrm{I}, \mathrm{I} 92$ canadensis hutchinsi $4 \mathrm{I}, 194$ 
Bubo virginianus virginianus 89,190 , 278,279

Buffle-head 36 , I90

Bunting, Indigo 8 , I10, 136 , I9I

Snow 122, I92, I93, 326

Butcher Bird I43, I92, 34I, 344

Buteo borealis borealis $77,190,193$. 276,277

lineatus lineatus $8,78,190,276,277$ platypterus 80 , I9I, I93, 276, 277

Buteonidæ 74, 273

Butorides virescens virescens 47 , I9I

Buzzard, Turkey 73, 194

Calcarius lapponicus lapponicus I22, 192, 193

Calidris leucophæa 59,193

Camptorhynchus labradorius 37, 194

Canvas-back 34, 194

Caprimulgi 97

Caprimulgidæ 97, 286

Cardinal 135, I95

Cardinalis cardinalis cardinalis $\mathbf{1 3 5}$, I95

Carduelis carduelis 185

Carpodacus purpureus purpureus IIO, I 8,190, I93, 316

Catbird 8, I67, I90, 315, 328, 348

Catharista urubu 74, 194

Cathartes aura septentrionalis 73, 194

Cathartidæ 73

Catoptrophorus semipalmatus inornatus 62,194

semipalmatus semipalmatus 6r, 194

Cepphi I7

Cepphus grylle r8, 194

Certhia familiaris americana I73, I92, I93, 35 I

Certhiidæ I73, 35I

Ceryle alcyon 9I, I4I, 190, 283

Centurus carolinus 96,194

Chrtura pelagica 99, I9I, 287

Chæturinæ 99

Charadriidæ 64,267

Charadrius dominicus dominicus 64 , 193,267

Charitonetta albeola 36 , I90

Chat, Yellow-breasted 8, III, I63, I9I

Chaulelasmus streperus 3I, I94

Chen hyperboreus nivalis 40, I94

Chenalopex ægyptiaca I83

Chickadee 8, I43, I74, I90, 352

Hudsonian $17.4,195$

Chordeiles virginianus virginianus 98 , I9I, I93, 286

Chuck-will's-widow 97, 194

Circus hudsonius 75, 190, 193, 273, 276

Cistothorus stellaris I7I, IOI
Clamatores roo

Clangula clangula americana 36,192 islandica 36,194

Coccyges 90

Coccyzinæ 90

Coccyzus americanus americanus 90 , I9I, 282

erythrophthalmus 9I, I9I, 282

Colaptes auratus luteus $96,190,193$. 285

Colinus virginianus virginianus 68 , I90, 268

Columbæ 69

Columbidæ 69,272

Colymbi I5

Colymbidæ I5, 263

Colymbus auritus 15,192

holbœlli I5, I92

Compsothlypis americana usneæ I52, I9I, I93

Coot 52, 192, 266

Coot family 52, 266

Cormorant 27, I92

Double-crested 27, I92

Cormorant family 27,265

Corvidæ 107, 29I

Corvinæ ro7

Corvus brachyrhynchos brachyrhynchos 107, 190, 279, 292, 293

corax principalis 107, I94

ossifragus 8,108 , I90

Coturnicops noveboracensis 50,192 , 280

Coturnix coturnix 183

Cowbird I10, II6, I46, I60, 190, 302, $3 \mathrm{I} 5$

Crake, Corn 51, I94

Crane, Sandhill I83

Whooping 183

Creciscus jamaicensis 50, I9I

Creeper, Brown I73, I92, I93, 351

Creeper family 173,351

Crex crex 5I 194

Crossbill II9, I92, 3I7

White-winged II9, I92, 3I7

Crow 107, 190, 279, 292, 293

Fish 8, 108, 190

Crow family 107,291

Cryptoglaux acadica acadica 88,190 , $280,28 \mathrm{r}$

funerea richardsoni 88, I94

Cuckoo, Black-billed 9I, I9I, 282

Yellow-billed 90, I91, 282

Cuckoo family 90,282

Cuculi 90

Cuculidæ 90,282

Curlew, Eskimo 64, 194, 267 
Hudsonian 63, 193

Long-billed 63, I94

Cyanocitta cristata cristata I07, I90, 263,291

Cygninæ 42

Cypseli 99

Dafila acuta 33, 192

Dendroica æstiva æstiva 8, IIO, I53, I9I, 264,347

cærulescens cærulescens 8 , I54, I9I, 193

castanea 156,193

cerulea 155 , I95

coronata $154,192,193,347$

discolor 8 , I10, I59, I9I

fusca $8,157,191,193$

magnolia 8, I55, I9I, 193

palmarum hypochrysea $159,192,193$

palmarum palmarum 158, 193

pensylvanica 8 , 110,156 , 191

striata 157,193

tigrina 153,193

vigorsi 158 , I9I, 193

virens 158 , I9I, I93

Dickcissel I36, I9I, 329

Diver, Great Northern I7, 190, 263

Dolichonyx oryzivorus 8,109 , III, I9I, 300

Dove, Mourning 73, 190, 272

Dove family 69,272

Dovekie 19, 194

Dovekie family 19

Dowitcher 54, 193, 267

Long-billed 55, 194

Dryobates pubescens medianus 93, 190, 284 villosus villosus $92,190,285$

Duck, Black 30, 190, 192

Harlequin 37, 194

Labrador 37, 194

Lesser Scaup 35, 190, 192

Ring-necked 36, 194

Ruddy 40, I92

Scaup 35, 190, 192

Wood 33, I91, 192

Duck family 28,265

River 30 -

Sea 34

Dumetella carolinensis 8, 167, 190, $315,328,348$

Eagle, Bald 82, 190, 193, 278

Golden 81, 194, 278

Northern Bald 82, 102

Ectopistes migratorius 69, I9I, 193, 272

Egret 45, 194

Snowy 46, 194
Egret family 45,265

Egretta candidissima candidissima 46,194

Eider 38, 194

King 38, I94

Elanoides forficatus 74, 194

Empidonax flaviventris 103,193 minimus 8,91 , 105, 191, 290 trailli alnorum 8, 104, I9I, I93 virescens 8 , 104, 191

Ereunetes mauri 59, 194 pusillus 59, 193

Erismatura jamaicensis 40, 192

Erolia ferruginea 183

Euphagus carolinus II4, I16, 193, 305

Falco columbarius columbarius 83 , 192, I93, 275

peregrinus anatum $83,190,193,274$ rusticolus obsoletus 83 , 194 sparverius sparverius $84,190,193$, 278

Falcon family 83,273

Falcones 74

Falconidæ 83, 273

Falconinæ 83

Fieldfare 189

Finch, Purple Iro, 118, 190, 193, 316

Finch family II7, 3II

Flicker, Northern 96, 190, 193, 285

Florida cærulea 46, 194

Flycatcher, Acadian 8, ro4, I9I

Alder 8, 104, I9I, I93

Crested IOI, I9I

Least 8, 9I, 105, 191, 290

Olive-sided 102, I9I, I93

Scissor-tailed 100, I94

Yellow-bellied I03, 193

Flycatcher family, Tyrant 100, 287

Fregata aquila 28, 194

Fregatidæ 28, 264

Fringillidx II7, 3II

Fulica americana 52, 192, 266

Fulicinæ 52

Fuligulinæ 34

Fulmar 25, 194

Fulmar family 25,265

Fulmarinæ 25

Fulmarus glacialis glacialis 25, 194

Gadwall 31, 194

Gallinæ 68

Gallinago delicata $54,190,193,266$

Gallinula galeata $5 \mathrm{I}$, I92

Gallinule, Florida 5I, 192

Purple 5I, 194

Gallinule family $5^{I}$

Gallinulinæ 5 I

Gannet 27, 194 
Gannet family 26,265

Garrulinæ I07

Gavia immer 17,190 stellata 17,192

Gaviidæ 17,263

Geothlypis trichas trichas IIo, I63, I9I, 347

Gnatcatcher, Blue-gray 176, 195

Gnatcatcher family 176

Goatsucker family 97,286

Godwit, Hudsonian 60, 194, 267 Marbled 60, 194

Golden-eye 36,192

Barrow's 36, 194

Goldfinch 8, I21, I90, 325

European 185

Goose, Canada 4I, 192

Egyptian I83

Greater Snow 40, 194

Hutchins' 4I, I94

Goose family 40,265

Goshawk 8, 77, 190, 274, 279

Grackle, Bronzed I15, 190, 193, 306

Purple I15, II6, II7, I9I, 306, 315

Grebe, Holboell's I5, 192

Horned 15, 192

Pied-billed I6, I9I, I92

Grebe family 15, 263

Grosbeak, Blue 187

Evening II7, 194

Pine II $8,192,316$

Rose-breasted I35, 191, 337

Grouse, Canada Ruffed 8, 69, I90 Ruffed 8, 68, 190, 27I

Grouse family 68,268

Grus americana 183 mexicana 183

Guara alba 42, 194

Guillemot, Black I8, I94

Guiraca cærulea cærulea 187

Gull, Bonaparte's 22, I92

Franklin's 264

Glaucous 264

Great Black-backed 21, 192

Herring 21, 192, 263, 264

Iceland 20, 194

Kumlien's 20, 194

Laughing 21, I94

Ring-billed 2I, 192, 264

Gull family 20, 264

Gyrfalcon, Black 83, 194

Hæmatopus palliatus 67, 194

Haliæetus leucocephalus alascanus 82,192

leucocephalus leucocephalus 82 , 190 , 193, 278

Harelda hyemalis 37 , 190
Hawk, Broad-winged 80, 191, 193, 276, 277

Chicken 75, 190, 193, 273, 274, 275.

Cooper's 76, 190, 193, 273, 274, 275, 279

Duck 83, 190, 193, 274

Fish 84, 191, 193, 274, 276

Hen 76, 190, 193, 273, 274, 275, 279

Marsh 75, 190, 193, 273, 276

Pigeon 83, 192, 193, 275

Red-shouldered 8, 78, 190, 276, 277

Red-tailed 77, 190, 193, 276, 277

Rough-legged 8I, 192, 278

Sharp-shinned $75,190,193,273$, 274,275

Sparrow 84, 190, 193, 278

Hawk family 74,273

Heath Hen I84

Helmitheros vermivorus 8, III, I48, IgI

Helodromas solitarius solitarius $6 \mathrm{I}$, 193

Hen, Heath 184

Herodias egretta 45, 194

Herodii 43

Herodiones 42

Heron, Black-crowned Night 47, I9I

Great Blue 45, I91, 192, 266

Green 47,191

Little Blue 46, 194

Heron family 45,265

Hesperiphona vespertina vespertina II7, 194

Highhole 96, 190, 193, 285

Hirundinidæ 138,338

Hirundo erythrogastra I39, I9I, 339

Histrionicus histrionicus 37, 194

Hummingbird, Ruby-throated 99, I9r, 287

Hummingbird family 99, 287

Hydrochelidon nigra surinamensis $24,194,265$

Hylocichla aliciæ aliciæ II7, I94, 356 aliciæ bicknelli 178,194

fuscescens fuscescens 8 , II0, I77, I9I, 356

fuscescens salicicola 177, I95

guttata pallasi $8,178,190,194,356$

mustelina 8,91 , III, 176, I9I, 356

ustulata swainsoni $178,194,356$

Ibides 42

Ibididæ 42

Ibis alba 42

falcinella 43

Glossy 43,194

White 42, 194

Ibis family 42 
Icteria virens virens 8, III, 163 , I9I

Icteridæ I09, 298

Icterus galbula 8, 9I, II4, I9I, 310 spurius 8 , III, II 3, I9I, 3IO

Ionornis martinicus 5I, 194

Iridoprocne bicolor 140, 190, 193, 339, 340

Ixobrychus exilis 44, I9I, I92, 35 I

Jæger, Long-tailed 20, 194

Parasitic 20, 194

Richardson's 20, 194

Jæger family 20,264

Jay, Blue 107, 190, 263, 291

Jay family I07, 29I

Junco hyemalis hyemalis $131,190,193$, 314,333

Slate-colored 131, 190, 193, 314, 333

Killdeer 65, 190, 193, 267, 268

Kingbird 8, I00, I9I, 287

Kingfisher, Belted 9I, I4I, 190, 283

Kinglet, Golden-crowned 175, 192, I93, 355

Ruby-crowned 175, 194, 355

Kinglet family 175,355

Kite, Swallow-tailed 74, 194

Kittiwake 20, 194

Knot 55, 194

Laniidæ I43, 34I

Lanius borealis I43, I92, 34I ludovicianus migrans $143,190,193$, $34 \mathrm{I}, 344$

Lanivireo flavifrons Iro, 146, I9I, 344, 345

solitarius solitarius 8,146 , I9I, 193

Laridæ 20,264

Larinæ 20, 264

Lark, Horned 105, 102, 290

Hoyt's Horned 106, 192

Prairie Horned 106, 190

Lark family 105, 290

Larus argentatus 21, 192, 263, 264 atricilla 2I, I94

delawarensis 21, 192, 264

franklini 264

hyperboreus 264

kumlieni 20,194

leucopterus 20, I94

marinus 2I, 192

philadelphia 22, I92

Limicolæ 52, 266

Limosa fedoa 60, 194 bæmastica 60, 194, 267

Lobipes lobatus 52, 194, 267

Longipennes 20

Longspur, Lapland I22, 192, 193

Loon 17,190

Red-throated 17, 192
Loon family 17,263

Lophodytes cucullatus 29,192

Loxia curvirostra minor II9, 192, 317 leucoptera II9, 192, 317

Macrochires 97

Macrorhamphus griseus griseus 54, 193,267

griseus scolopaceus 55, 194

Mallard 30, 192

Man-o'-war-bird 28, 194, 264

Man-o'-war-bird family 28, 264

Mareca americana 31, 192

Marila affinis 35, 190, 192

americana 34,192

collaris 36 , 194

marila $35,190,192$

valisineria 34,194

Martin, Purple I38, I86, I9I, 338, 340

Meadowlark II 3, I90, 280, 308

Melanerpes erythrocephalus 94, 190, 193

Meleagris gallopavo silvestris 184

Melospiza georgiana 132, 190, 193, 336 lincolni lincolni I32, I93, 336 melodia melodia IIO, I3I, I90, 3I4, $315,329,334$

Merganser 28, 192

Hooded 29, 192

Red-breasted 29, I92

Merganser family 28

Merginæ 28

Mergus americanus 28, 192

serrator 29, 192

Micropalama himantopus 55, 194

Micropodidæ 99,287

Mimidæ 167,348

Mimus polyglottos polyglottos 167 , I9I, 195

Mniotilta varia 8, III, I47, I9I, I93, 347

Mniotiltidæ I47, 346

Mockingbird I67, I9I, I95

Molothrus ater ater II0, I16, 146, 160, 190, 302, 31 5

Motacillidæ $\mathrm{r} 66,348$

Murre, Brünnich's I8, 194

Muscivora forficata 100,194

Myiarchus crinitus Ior, I9I

Myiochanes virens I03, III, I9I, 290

Nannus hiemalis hiemalis 8 , I7I, I9a I93, 35I

Nettion carolinense 32, 192 crecca 32

Nighthawk 98, I9I, 193, 286

Numenius americanus 63, 194 borealis $64,194,267$

hudsonicus 63,193 
Nuthatch, Red-breasted $8,173,190$, I93, 35I

White-breasted 173, 190, 35I

Nuthatch family I $73,35 \mathrm{I}$

Nuttallornis borealis I02, I9I, 193

Nyctea nyctea $89,192,282$

Nycticorax nycticorax nævius 47, I9I

Oceanites oceanicus 26, 194

Oceanitinæ 26

Oceanodroma leucorhoa 26, 194

Ochthodromus wilsonius 67,194

Odontophoridx 68,268

Oidemia americana 38, 192 deglandi 39, 190, 192 perspicillata $40,190,192$

Old-squaw 37 , Igo

Olor columbianus 42,194

Oporornis agilis 162,193

formosus $8,161,191$ philadelphia I62, I93

Oriole, Baltimore 8, 9I, II4, I9I, 3I0 Orchard 8, III, II 3 , I9I, 3ro

Oriole family 109,298

Oscines 105

Osprey 84, 191, 193, 274, 276

Otocoris alpestris alpestris 105, 192, 290

alpestris hoyti 106, 192 alpestris praticola 106, 190

Otus asio asio $88,190,279,280,28 \mathrm{I}$

Ovenbird I10, I49, I60, I9I

Owl, Barn 85, I90

Barred 79, 87, 88, 190, 279

Great Gray 87, 194

Great Horned 89, 190, 278, 279

Hawk 90, 194

Long-eared 86, I90, 28I

Richardson's 88, 194

Saw-whet 88, I90, 280, 28I

Screech 88, 190, 279, 280, 281

Short-eared 86, 190, 193, 280

Snowy $89,192,282$

Owl family 85,278

Barn 85

Horned 86

Oxyechus vociferus $65,190,193,26 \%$, 268

Oyster-catcher 68, 194

Paludicolæ 48

Pandion haliaëtus carolinensis 84 , I9I, 193, 274, 276

Pandionidæ 84, 274

Paridæ 174, 352

Partridge, Gray 184, 191 Hungarian 184

Partridge family 68,268

Passer domesticus 169, 186, 191
Passerculus princeps 123, 192, 193, 328

sandwichensis savanna $8,124,190$, 193, 327

Passerella iliaca iliaca $133,192,193$, $314,335,336$

Passeres I00

Passerherbulus caudacutus I26, 190, 330

henslowi henslowi 125, I9I

maritimus maritimus $8,126,127$, I 90,330

nelsoni nelsoni 127,193

nelsoni subvirgatus 127, 193

Passerina cyanea 8, IIO, I36, 19I

Pelecanidx 28, 265

Pelecanus occidentalis 28, 194

Pelican, Brown 28, 194

Pelican family 28,265

Pelidna alpina sakhalina 58, I93

Penthestes atricapillus atricapillus 8 , I43, I74, I90, 352

hudsonicus hudsonicus 174,195

Perdix perdix 184, I9I

Petrel, Leach's 26, 194 Wilson's 26, 194

Petrel family 25, 265

Long-legged Storm 26

Storm 26

Petrochelidon lunifrons lunifrons $\mathbf{I} 39$, I86, I9I, 193, 339

Pewee, Wood 103, III, I9I, 290

Phalacrocoracidæ 27, 265

Phalacrocorax auritus auritus 27, 192 carbo 27,192

Phalarope, Northern 52, 194, 267

Red 52, 194

Wilson's 53, 194

Phalarope family 52, 266

Phalaropodidæ 52, 266

Phalaropus fulicarius 52,194

Phasiani 68

Phasianus colchicus 184 , I9I torquatus 184 , I9I

Pheasant, English 184, I9I Ring 184, I9I

Philohela minor 53, 190, 193, 266, 268

Phlœotomus pileatus abieticola 94, 190

Phobe Ior, IIo, 190, 289

Pici 92

Picidæ 92, 284

Picoides arcticus 93, 194

Pigeon, Passenger 69, 191, 193, 272

Pigeon family 69,272

Pinicola enucleator leucura II8, I92, 316 
Pintail 33, I92

Pipilo erythrophthalmus erythrophthalmus 8 , III I I 34, I $90,280,337$

Pipit I66, I92, I93, 348

Piranga erythromelas 8,91, I 10, 137, I9I, 338

ludoviciana 137,195

rubra rubra 138 , 195

Pisobia bairdi 57, I94, 268

fuscicollis $56,57,193$

maculata $56,193,267,268$

minutilla 58, 193

Planesticus migratorius migratorius 90,91 , III, I79, I90, 279, 280, 328, 356

Plectrophenax nivalis nivalis 122,192, 193,326

Plegadis autumnalis $43, I 94$

Plover, Black-bellied 64, 193

Golden 64, 193, 267

Piping 67, 193

Semipalmated 66, 193

Upland 62, 19I, 193, 267, 268

Wilson's 67, I94

Plover family 64,267

Podilymbus podiceps I6, I9I, I92

Polioptila cærulea cærulea 176 , 195

Polioptilinæ 176

Poœcetes gramineus gramineus 123, $190,327,328,329$

Porzana carolina 49, I9I, I92, 266

Procellariidæ 25,265

Procellariinæ 26

Progne subis subis 138, 186, I9I, 338, 340

Protonotaria citrea 148,195

Puffininæ 25

Puffinus gravis 25, 194

Pygopodes I5

Quail, Connecticut 68

European I83

Migratory 183

Quail family 68

Querquedula discors 32, 192

Quiscalus quiscula æneus II5, I90, 193, 306

quiscula quiscula II $5,116,117$, I9I, 306,315

Rail, Black 50, I9I

Clapper 8, 48, 190, 266

King 48, I9I

Virginia 49, I9I, I92, 266

Yellow 50, I92, 280

Rail family 48,266

Ralli 48

Rallidæ 48, 266

Rallinæ 48, 266
Rallus crepitans crepitans $8,48,190$, 266

elegans 48 , I9I

virginianus 49, I91, 192, 266

Raptores 73

Raven, Northern 107, 194

Recurvirostra americana $53,194,266$, 268

Recurvirostridæ 53, 266

Redhead 34, 192

Redpoll 120, 192

Greater I2I, 195

Hoary 120, 195

Redstart I10, I66, I9I, 347

Regulinæ 175

Regulus calendula calendula I75, I94, 355

satrapa satrapa $175,192,193,355$

Rhynchopidæ 25, 265

Rhynchops nigra 25, 194

Riparia riparia I4I, I9I, I93, 340

Rissa tridactyla tridactyla 20 , 194

Robin 90, 91, III, 179, 190, 279, 280, 328,356

Sanderling 59, 193

Sandpiper, Baird's 57, 194, 268

Bartramian 62, 191, 193, 267, 268

Buff-breasted 63, I94

Curlew 183

Least 58,193

Pectoral 56, 193, 267, 268

Purple 56, 192, 193

Red-backed 58, 193

Semipalmated 59, 193

Solitary 6I, I0.3

Spotted 63, I9I, 268

Stilt $55,183,194$

Western 59, 194

White-rumped $56,57,193$

Sandpiper family $53,266,267$

Sapsucker, Yellow-bellied 8, 93, I90, I93, 284

Sarcorhamphi 73

Sayornis phœbe 101, 110, 190, 289

Scolopacidæ 53,266

Scoter 38, 192

Surf 40, 190, 192

White-winged 39, 190, 192

Scotiaptex nebulosa nebulosa 87, 194

Seiurus aurocapillus IIo, I49, I60, I9I motacilla 8, III, I6I, I9I

noveboracensis notabilis 161,193

noveboracensis noveboracensis 160 , 193

Setophaga ruticilla $x$ 10, I66, 19r, 347

Shearwater, Greater 25, 194

Shearwater family 25, 265 
Shoveller 33, 194

Shrike, Migrant I43, 190, I93, 34I, 344

Northern 143, 192, 34I, 344

Shrike family I43, 34I

Sialia sialis sialis III, I80, I86, 190 , 328,360

Siskin, Pine 121, 192, 193, 326

Sitta canadensis 8,173, I90, I93, 351 carolinensis carolinensis 173,190 , 351

Sittidæ 173,351

Skimmer, Black 25, 194

Skimmer family 25, 265

Snipe, Wilson's 54, 190, 193, 266

Snowflake 122, I92, I93, 326

Somateria dresseri 38, 194 spectabilis 38,194

Sora 49, I9I, 192, 266

Sparrow, Acadian Sharp-tailed 127, 193

Chipping III, I29, I9I, 315, 329, 332

English 169, 186, 191, 261, 317

Field I10, I30, 90, 315, 329, 332, 333

Fox 133, 192, 193, 314, 335, 336

Grasshoper 124, I9I, 328, 329

Henslow's 125, 19I

Ipswich 123, I92, 193, 328

Lark 329

Lincoln's 132, 193, 336

Nelson's 127, 193

Savanna 8, 124, 190, 193, 327

Seaside 8, 126, 127, 190, 330

Sharp-tailed 126, 190, 330

Song I IO, I3I, 190, 314, 315, 329, 334

Swamp 132, 190, 193, 336

Tree 129, 192, 314, 33I

Vesper I23, 190, 327, 328, 329

White-crowned 128, 193, 335, 336

White-throated 8, 129, 190, 193, 314, $330,335,336$

Sparrow family II7, 3II

Spatula clypeata 33, I94

Sphyrapicus varius varius $8,93,190$, 193,284

Spinus pinus I21, 192, 193, 326

Spiza americana I36, I9I, 329

Spizella monticola monticola I29, 192 3I $4,33 \mathrm{I}$

passerina passerina III, I29, I9t, 3 I $5,329,332$

pusilla pusilla I10, 130, 190, 315, 329, 332, 333

Squatarola squatarola 64,193

Starling 185, I9I, 26I, 295

Steganopodes 26

Steganopus tricolor 53, 194
Stelgidopteryx serripennis I4I, I9I

Stercorariidæ 20,264

Stercorarius longicaudus 20, 194 parasiticus 20, 194

Sterna antillarum 24, 194, 265

dougalli $23,191,262$

fuscata 24,194

hirundo 22, 191, 265

paradisæa 23, 194

Sterninæ 22

Striges 85,278

Strigidæ 86

Strix varia varia $87,88,190,279$

Sturnella magna magna II $3,190,280$, 308

Sturnidx 295

Sturnus vulgaris 185, I9I, 261, 295

Sula bassana 27, 194 leucogastra 26, 194

Sulidæ 26,265

Surnia ulula caparoch 90,194

Swallow, Bank I4I, I9I, I93, 340

Barn 139, I9r, 339

Cliff 139, 186, 191, 193, 339

Eave I39, 186, I91, 193, 339

Rough-winged I4I, I9I

Tree 140, 190, 193, 339, 340

Swallow family 138,338

Swan, Whistling 42, 194

Swan family 42

Swift, Chimney 99, I91, 287

Swift family, Spine-tailed 99

Swimmers, Lamellirostral 28

Long-winged 20

Totipalmate 26

Tube-nosed 25

Sylviidæ I75, 355

Tanager, Scarlet 8, 9I, IIO, I37, I9I, 338

Summer 138, 195

Western 137,195

Tanager family 137,338

Tangaridæ 137,338

Teal, Blue-winged 32, 192

European 32

Green-winged 32, 192

Telmatodytes palustris palustris $\mathbf{I 7 2}$, $190,35 \mathrm{I}$

Tern, Arctic 23, 194

Black 24, 194, 265

Common 22, 191, 265

Least 24, 194, 265

Roseate 23, 191, 262

Sooty 24, 194

Tern family 22,264

Tetraonidæ 68,268

Thrasher, Brown 8, III, I68, I90, 349 
Thrasher family 167,348

Thrush, Bicknell's 178, 194 Gray-cheeked 177, I94, 356

Hermit 8, 178, I90, 194, 356

Olive-backed 178, 194, 356

Willow 177, I95

Wilson's 8, I I0, I77, I9I, 356

Wood 8, 9I, III, I76, I9I, 356

Thrush family I76, 355

Thryothorus ludovicianus ludovicianus II, I69, 190

Titlark 166, 192, 193, 348

Titmouse, Tufted 174, I95

Titmouse family 174,352

Totanus flavipes $6 \mathrm{I}, 193$ melanoleucus 6o, 192, 193

Towhee 8, III, I34, 190, 280, 337

Toxostoma rufum 8, III, 168, 190, 349

Tringa canutus 55,194

Trochili 99

Trochilidæ 99, 287

Troglodytes aëdon aëdon 170, 191, 350

Troglodytidæ 169,350

Tryngites subruficollis 63,194

Tubinares 25

Turdidæ 176,355

Turdinæ 176

Turdus pilaris 189

Turkey, Wild I84

Turnstone, Ruddy 67, 193

Turnstone family 67,266

Tympanichus cupido 184

Tyrannidæ IOO, 287

Tyrannus tyrannus 8 , I00, I9I, 287

Tyrant Flycatcher family 100, 287

Uria lomvia lomvia I8, I94

troille troille I9

Veery 8, IIO, I77, I9I, 356

Vermivora celata celata 151,193

chysoptera I49, I50, I87, 188, I89, I9I

lawrencei I49, 187

leucobronchialis $\mathrm{I} 87, \mathrm{I} 88$

peregrina I5I, 193, 347

pinus 8 , III, I49, I50, 187, I88, I89, I9I

rubricapilla rubricapilla 150 , I9I, I93

Vireo, Blue-headed 8, 146, 191, 193

griseus griseus 8, II I, I47, I9I, 344, 345

Philadelphia 145, 193

Red-eyed 8, 110, 144, 191, 344, 345

Solitary 8, I46, I9I, I93

Warbling 8, I45, I46, I9I, 344, 345

White-eyed 8, III, I47, I9I, 344, 345

Yellow-throated I 10, I46, I9I, 344, 345
Vireo family 144,344

Vireonidæ 144,344

Vireosylva gilva gilva $8,145,146,191$, 344,345

olivacea 8, I Io, 144, 191, 344, 345

philadelphica 145, 193

Vulture, Black 74, 194

Turkey 73, 194

Vulture family, American 73

Wagtail family I66, 348

Warbler, Bay-breasted I56, 193

Black and White 8, III, I47, I9I, I93, 347

Blackburnian 8, I57, I9I, 193

Black-poll I57, 193

Black-throated Blue 8, I54, 19I, 193

Black-throated Green 158, 191, 193

Blue-winged 8, III, I 49, I50, I87, I88, 189 , 191

Brewster's 187, 188

Canada 8, 165, 191, 193

Cape May 153, 193

Cerulean I55, I95

Chestnut-sided 8, I I0, 156, I9I

Connecticut 162, 193

Golden-winged $149,150,187,188$, 189, 191

Hooded 8, 164, I9I

Kentucky 8, I6I, I9I

Lawrence's I49, 187

Magnolia 8, 155, I9I, 193

Mourning 162, 193

Myrtle 154, 192, 193, 347

Nashville I50, I9I, I93

Northern Parula 152, 191, 193

Orange-crowned I5I, 123

Palm 158, 193

Pine 158, 191, 193

Prairie 8, I10, 159, 191

Prothonotary 148, 195

Tennessee I5I, 193, 347

Wilson's 164, I93

Worm-eating 8, III, I48, I9I

Yellow 8, I10, 153, 191, 264, 347

Yellow Palm 159, 192, 193

Warbler family I75

Wood 147,346

Water-thrush I60, 193

Grinnell's I6I, 193

Louisiana 8, III, I6I, I9I

Waxwing, Bohemian 142, 195

Cedar III, 142, 190, 340

Waxwing family 142,340

Whip-poor-will 97, 19I, 286

Willet 6r, 194

Western 62, 194

Wilsonia canadensis 8,165, I9r, 193

citrina $8,164,191$ 
Wilsonia canadensis pusilla pusilla 164,193

Woodcock 53, 190, 193, 266, 268

Woodpecker, Arctic Three-toed 194

Downy 93, 190, 284

Golden-winged $96,190,193,285$

Hairy $92,190,285$

Northern Pileated 94, 190

Pigeon 96, 190, 193, 285

Red-bellied 96, r94

Red-headed 94, 190, 193

Woodpecker family 92,284

Woodquoi $96,190,193,285$

Wren, Carolina II, 169, 190

House 170, 191, 350

Long-billed Marsh 172, 190, 351
Wren, Short-billed Marsh 171, 19I, Winter 8, 171, 190, 193, 351

Wren family 169,350

93. Xanthocephalus xanthocephalus III, 194

Yellow-hammer 96, 190, 193, 285

Yellow-legs 6r, 193 Greater 60, 192, 193

Yellowthroat, Maryland I10, 163, 191, 347

Zamelodia ludoviciana 135, I9I, 337

Zenaidura macroura carolinensis 73 , 190,272

Zono̊trichia albicollis $8,129,190,193$, 3 I $4,330,335,336$

leucophrys leucophrys I28, 193, 335. 336 



